


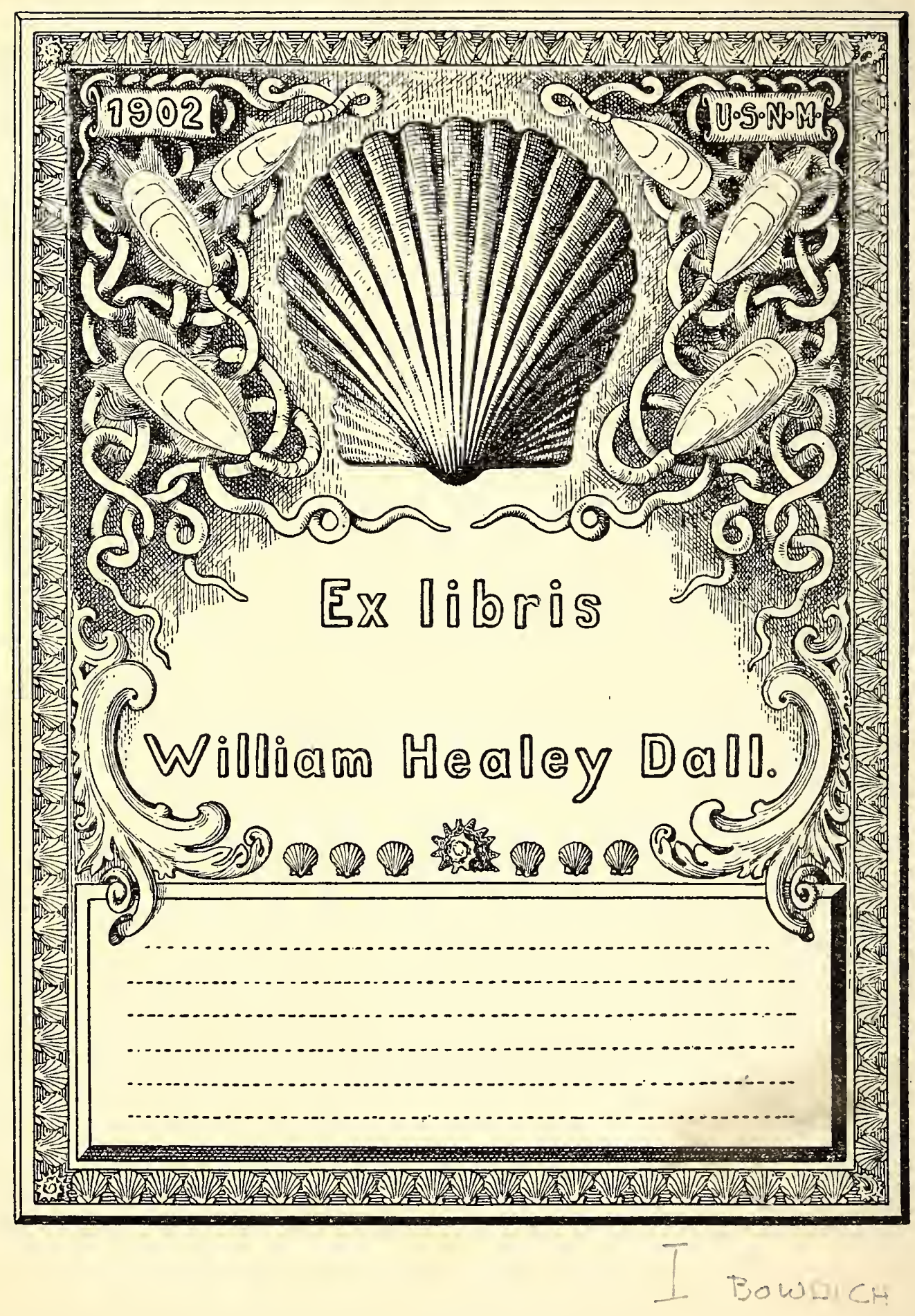




\section{(1)} Sectional Litorary 

I BOWDiCH 



\title{
ELEMENTS OF GONGHOLOGY,
}

INCL UDING

\section{THE FOSSIL GENERA}

\author{
AND

\section{THE ANIMALS.}

\section{Bx T. EDWARD BOWDICH, EsQ.}

HONORARY MEMBER OF THE CAMBRIDGE PHILOSOPHICAL SOCIETY AND OF THE WETTERAVIAN SOCIETX OF HANAU. MFMBER UF THE GEOGRAPHICAL SOCIETY OF PARIS. CONDUCTON OF THE MISSION TO ASHANTEE.

\section{PART I. UNIVALVES.}

WITH UPWARDS OF 500 FTGURES.

\section{PARIS,}

PRINTED BYY J. SMITH,

AND SOLD BY TREUTTEL AND WÜRTZ, SOHO-SQUARE, LONDOÑN.

1822.

(Price T'wenty Shillings.) 



\title{
PREFA CE.
}

\author{
mpentwmen
}

$\mathbf{T}$

$I$ Hrs Manual, like those of the Mammalia and the Ornithology already published, originated in the notes and drawings collected during a study of the subject, preparatory to a second travel in Africa. I had intended to arrange the similar materials for the publication of the Reptiles and Fish before the Mollusca, until a further progress in the study of Geology convinced me that the present Manual was not wanting to the Zoologist alone.

M. Brongniart has shown that the Formations containing the remains of marine shells, very rarely, and then under peculiar and evident local causes, present those of freshwater shells; and that the contrary had been alleged, because Genera containing both marine and fresh-wwater shells, differing not merely in specific but in generic characters, had not been reformed or subdivided. M. Lamarck. acknowledged the justice of the observation, and resumed his labours, which had previously advanced this branch of Natural History considerably towards perfection, by establishing separations of marine, fresh-water, and ter. restrial shells; but, unfortunately, his Extrait du Cours de Zoologie, published in 1812, contains the mere outline of-his system, without the descriptions of the genera; and the lst and only part (which appeared two years ago) of the 6th volume of his Histoire Naturelle des Animaux sans $V$ ertebres, without figures, contains merely the three or four first genera of the Univalves, and reminds us so frequently of the melancholy affliction which has now compelled this illustrious Naturalist to depend entirely on the eye-sight of others, that the appearance of the remain- 
ing parts, if they should appear, must be hailed by the friends of science with much less confidence, although with equal admiration and gratitude.

The system of classification desirable to the Geologist, is that by which a shell may be readily and accurately determined, without considering the animal which has inhabited it. Such a system is equally convenient to the Conchologist, when each genus is followed by a reference to the place which the animal occupies in the Natural System, which should always be adjoined. To be unable to determine the shell, unless we found the animal, would be like having no other aid than Crystallography for the study of Minerals.

These elements are principally compiled from Cuvier's "Mémoires pour servir à l'Histoire et à l'Anatomie des Mollusques," and the $2 \mathrm{l}$ vol. of the "Règne Animal" of the same author; M. Lamarck's Mremuiros sur les Fossiles des Environs de Paris;" M. Brongniart's "Mémoires sur des Terrains qui paroissent avoir étéformés sous l'Eau Douce," and others on the same subjects, scattered through the 22 quarto volumes of the "Annales du Museum;" M. Blainville's and M. Defrance's articles in the "Dictionnaire des Sciences Naturelles;" M. de Ferussac's "Histoire INaturelle, générale et particulière, des Mollusques T'errestres et Fluviatiles;" and many other rare and costly works, collected in the splendid library of Baron Cuvier, to which I have had access at all hours, with the liberty of taking home whatever I pleased, for the last two years.

The figures which illustrate the system of M. de Ferussac have been copied from those which accompany his work, with the exception of such as were to be found in the Museum. Almost all the other figures of the recent, and some few of the fossil shells, have been drawn from the. objects themselves; which I have invariably been permitted to take home from the Museum for that purpose, without being limited either to time or number. I have occasionally been favoured with such specimens as were not to be found there, from the cabinets of MM. Lamarck and Dufresne. 
The remaining part will contain the Bivalves, Multivalves, and the Sub-Coronalia and Vermicularia of Lamarck (the Brachiopoda and Tubicole of Cuvier): a figure of the entire shell, of each valve, and of the hinges and teeth, when at all complicated, will be given. The Animals and Fossil Genera will also be included.

I beg to repeat that this Manual, as well as the others, has been compiled for those of my countrymen, whose remote situations in our colonies do not permit of their acquiring so desirable a species of knowledge, by the study of collections; as well as for those who, like myself, may cultivate Natural History, as the most agreeable delassement to mathematical studies.

Paris, November \&, 1821. 



\section{INTRODUCTION.}

aventerenter

Fossir shells, being necessarily without brilliance, colours, or beauty, and frequently imperfect, were formerly rejected from collections as destitute of interest; but since it has been observed that these fossils are precious monuments for the study of the revolutions undergone by different points on the surface of the globe, they have become ohjocts of the greatest interest to the Naturalist (1).

It appears to have been proved that the shells, testaceous vermicularia, echini, and different species of polypi which are found so profusely in the fossil state beneath the soil or on its surface, even in the middle of continents and on the highest mountains (2), are the remains of multitudes of marine animals which lived in these places, and that several of the species are analogous to those now inhabiting the seas (3). For, as the quantity of these remains is enormous, since we know of masses nearly a hundred miles in extent, and as shells of an extreme thinness and fragility are found entire amongst them, we cannot but conclude that their animals have really lived in these parts of the globe, and, consequently, that the sea has formerly been stationary there $\left({ }^{4}\right)$.

(1) Conchology, when rendered subservient to geognostic investigations. assumes the rank of an useful science, and then becomes a subject of the highest importance. Bulimus trifasciatus, a very common West Indian shell, occurs imbedded in the same limestone which incloses the fossil human skeleton, lately sent to the British Museum, from the grande terre of Guadaloupe, by Sir A. Cochrane, proving that rock to be of modern date, and contemporaneous with the existing creation of animals.-Leach's Zoological Miscellany. Vol. $i$, p. 42.

(2) According to Ulloa, shells have been found at the height of 14,220 feet above the sea, on a mountain in Peru.

(3) M. Defrance has discovered at least 500 species of fossil shells in the calcaire grossier at Grignon, the equivalent of the London clay.

(4) Les terrains les plus bas, les plus unis, excavés jusqu'à de très-grandes profondeurs, ne montrent que des couches horizontales de matières varićes, enveloppant presque toutes d'imnombrables produits de la mer. Des couches 
The shells whose analogous species do not live in our seas, but in those of warm climates, form a part of the fossils found in the north of Europe. The Nautilus Pompilius found at Courtagnon, and the remains of which are not uncommon at Grignon, is one of the

pareilles, des produits semblables, composent les collines jusqu'aux plus grandes hauteurs. Quelquefois les coquilles sont si nombreuses, qu'elles forment à elles seules toute la masse du sol. Presque partout elles sont si bien conservées, que les plus petites d'entre elles gardent leurs parties les plus délicates, leurs crêtes les plus subtiles, leurs pointes les plus déliées. Elles s'élèvent à des hauteurs supérieures au niveau de toutes les mers, et où nulle mer ne pourroit être portée aujourd'hui par des causes existantes. Elles ne sont pas seulement enveloppées dans des sables mobiles, mais les pierres les plus dures les incrustent souvent ét en sont pénétrées de toute part. Toutes les parties du monde, tous les hémisphères, tous les continens, toutes les îles un peu considérables présentent le même phénomène. On est donc bientôt disposé à croire, non seulement que la mer a envahi toutes nos plaines, mais qu'elle y a séjourné longtemps et paisiblement pour y former des dépôts si étendus, si épais, en partie si solides, et contenant des dépouilles si bien conservées." Le temps n'est plus où l'ignorance pouvoit soutenir que ces restes de corps organisés étoient de simples jeux de la nature, des produits conçus dans le sein de la terre par ses forces créatrices. Une comparaison scrupuleuse de leurs formes, de leur tissu, souvent même de leur composition chimique, ne montre pas la moindre différence entre ces coquilles et celles que la mer nourrit; elles ont donc vécu dans la mer; elles ont été déposées par la mer : la mer existoit donc dans les lieux où elle les a laissées; le bassin des mers a donc éprouvé au moins un changement, soit en étendue, soit en situation. Voilà ce qui résulte déjà des premières fouilles, et de l'observation la plus superficielle.

Ies traces de révolutions deviennent plus imposantes quand on s'élève un peu plus haut, quand on se rapproche davantage du pied des grandes chaînes.

Il y a bien encore des bancs coquilliers; on en aperçoit même de plus épais, de plus solides : les coquilles y sont fout aussi nombreuses, tout aussi bien conservées; mais ce ne sont plus les mêmes espèces; les couches qui les contiennent ne sont plus aussi généralement horizontales. EHles se redressent obliquement, quelquefois presque verticalement. Au lieu que, dans les plaines et les collines plates, il falloit creuser profondément pour connoître la succession des bancs, on les voit ici par leur flanc, en suivant les vallées produites par leurs déchiremens. D'immenses amas de leurs débris forment au pied de leurs escarpemens des collines arrondies, dont chaque dégel et chaque orage augmentent la hauteur.

Et ces bancs redressés, qui forment les crêtes des montagnes secondaires, ne sont pas posés sur les bancs horizontaux des collines qui leur servent de premiers échelons; ils s'enfoncent au contraire sous eux. Ces collines sont appuyées sur leurs pentes. Quand on perce les couches horizontales dans le voisinage des couchies obliques, on retrouve celles-ci dans la profondeur : quelquefois mîme, quand les couches obliques ne sont pas trop élevées, leur. sommet est couronné par des couches horiźontales. Les couches obliques sont donc plus anciennes que les couches horizontales; et, comme il est impossible qu'elles n'aient pas été formées horizontalement, il est évident qu'elles ont été relevées, qu'elles l'ont été avant que les autres s'appuyassent sur elles.

Ainsi la mer, avant de former les conches horizontales, en avoit formé d'autres, qu'une cause quelconque avoit brisées, redressées, bouleversées de mille manic̀res. Il y a donc eu aussi au moins un changement dans le sein de 
numerous instances (1). The fragments of palm-trees; the fossit masses of gum-elastic; the impressions of exotic ferns in slate and coal ; and the fossil bones of the Elephant, Grocodile, etc. found in England, France, Germany, and other parts of Europe, seem to attest a mutation of climate (2):

Guvier and Brongniart were the first who announced the existence of formations, anterior to history, composed in the same manner and presenting the same characters, although situated at great distances from each other, and containing Terrestial and Fresh-Water instead of Marine productions (3). It is impossible to admit the hypothesis of the transport of these terrestrial productions to the sea by means of rivers. They might have carried into the sea some remains of vegetables and some fluviatick and terrestrial shells, but then the formations which are composed of them ought

cette mer qui avoit précédé la nôtre; elle a éprouvé aussi au moins une catastrophe; et comme plusieurs de ces bancs obliques qu'elle avoit formés les premiers s'élèvent au-dessus de ces couches horizontales qui leur ont succédé, et qui les entourent, cette catastrophe, en rendant ces bancs obliques, les avoit aussi fait saillir au-dessus du niveau de la mer, et en avoit fait des îles, ou au moins des écueils et des inégalités, soit qu'ils eussent été relevés par une extrémité, ou que l'affaissement de l'extrémité opposée eût fait baisser les eaux; second résultat non moins clair, noll moins demontré que le premier, pour quiconque se donnera la peine d'étudier les monumens qui l'appuient.Cuvier, Discours sur la Théorie de la Terre. Paris, 1821.

(1) See the note on that singular shell the Trochus agglutinans, p. 35.

The Terebellum perditum (the analogous living species of which is not known) is found in great numbers and of all ages at Grignon, which M. Lamarck consider's would not have been the case unless the enormous quantity of marime shells had lived in that region, instead of being accumulated there by some great catastrophe. At Courtagnon, near Rheims, an enormous bed of fossil shells discovers itself in several points; it proceeds from east to west, appears again at Grignon and-some other places, and from M. Lamarck's comparison of the species with those found in Hampshire, appears to have extended to that part of England. If so, there is reason to believe that this bed has been divided by the Channel since its formation; and, consequently, that its formation was anterior to the last invasion of the sea.

(2) The rocks of the western coasts of France are interlarded with Gryphites, Ammonites and other shells (coquilles pelagiennes) known to inhabit the sea only at great depths. Recent littoral shells have been found fixed on these fossil deep-water shells, which are also common in the hills called VachesNoires. There is a pottery in that neighbourhood which is supplied with clay from that part of the beach which is uncovered at low water; this clay, which is said to be very superior, contains quantities of deep-water fossil shells. It would seem, therefore, that these parts are not now subjected to the sea for the first time. Again, the fossil marine shells found more than 60 feet deep in the earth, probably were not deposited during the last invasion or passage of the sea.-Iydrogeologie, par J. B. Lamarck. Pages 85, 86.

(3) Lamanon is said to have observed immense beds of fresh-water shells on beds of marine shells in the mountains of Provence. 
to present the forms and all the characters of alluvium; that is to say, a mixture of all sorts of heterogeneous matters, more framments than entire bodies, coarse sands, unequal and irregular strata. We find nothing of this kind in the Fresh-Water Formations; the limestone is almost pure, every thing is in its place and perfectly entire, the most delicate shells present themselves in complete preservation; indeed, fragments of them are scarcely to be found in this formation, whilst, in the marine, fragments are met with in large quantities. We must, therefore, suppose a great tranquillity in the waters wherein these shells have lived. They are deposited in beds, often very thin and perfectly horizontal, like the masses of limestone and the zones of silex which they contain; the silex is in beds, frequently continuous, and never in rolled pieces. The disengagements of gas, indicated by the tubulures, have almost always been made vertically, and have often proceeded from the same plane, which is a further proof of the tranquillity of the liquid and the homogeneity of the Formation. Lastly, the immense extent of these deposits, which occupy spaces of more than 1200 square leagues, and which in so great a surface do not present any trace of disorder, renders this hypothesis perfectly admissible (1).

The extent of these masses of Fresh-Water Formation ought not to astonish us; we know of others at least as vast in North America. If the lakes Superior, Michigan, Huron, Erie, and Ontario deposited stony layers on their beds and became dry, they would leave Fiesh-Water Formations more extensive than any of those just described (2).

Among the different stages of alteration in which we find fossil shells, the most frequent is that in which only the animal part has

(1) M. Brongniart remarks that marine and fresh-water shells have in no instance been found mix ed together, except in the quarries of Grès at Beauchamp near Pierrelaie, where the cause is local; for the fresh-water limestone, which forms the surface of the soil, reposes immediately on the marine sand which forms the bed or fond; the mixture of the two, therefore, in this point of contact is natural. M. Defrance has since adduced and explained another instance; see note on the Genus Helix. At Montmartre the Calcaire Marin forms a kind of mamelon or small hummock, and the gypsum in depositing itself on these beds, which are porous and friable, has enveloped the marine shells which they contain. Indeed, there is no proof that gypsum may not be a salt-water deposit; the upper marine formation contains small beds of gypsum at intervals, and the oysters are often covered with chrystals of selenite. There are only 3 fresh-water genera of bivalve shells, and it is remarkable that no species of either has been found in the Fresh Water Formation.

(2) Fresh-water deposits must not be determined by the presence of doubtful shells, but, like that of the environs of Paris, on the constant presence of a considerable majority of shells not found elsewhere, and on the constant absence of all marine bodics. Sce Pl. 4. 
been destroyed, that is to say, the gelatinous or membraneous portion which is mixed with the cretaceous part; so that after its destruction the shell is almost exclusively composed of calcareous matter. It has lost its brilliance, its colours, and often even its mother of pearl, if it had any, for it owed all these to the presence of the animal part. It has generally become quite white, but sometimes, having been long buried in a slime containing coloured particles, it has acquired a peculiar hue, not its own. Other fossils have not only lost the animal part, but even their substance has been transformed into siliceous matter; in this case, the closer approximation of the component parts leaves a small void space around the shell, in the stone wherein it is imbedded, more or less interrupted by lateral adherences. Shells have sometimes been so peculiarly disposed by volcanic eruptions, as to preserve their natural colours even in tho fossil state.

'We scarcely condescend to examine microscopic shells, from their insignificant size; but when we reflect that it is by means of the smallest objects that Nature every where produces the most astonishing and remarkable phenomena, they become highly interesting, from their multiplication or abundance, and their consequent influence on the composition and extent of the masses composing the exterior crust of the globe. Whatever Nature may seem to lose in point of volume in the production of such bodies, is amply made up by the number of the individuals, which she multiplies with admirable promptitude to infinity. The remains of these minute animals, therefore, have much more influence on the surface of the globe than those of Elephants, Hippopotami, or Whales. 



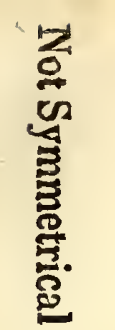

害

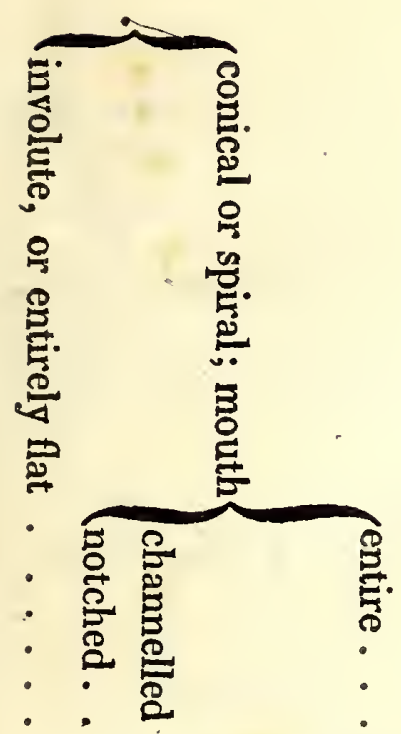

$\overbrace{}^{2}$

骂农
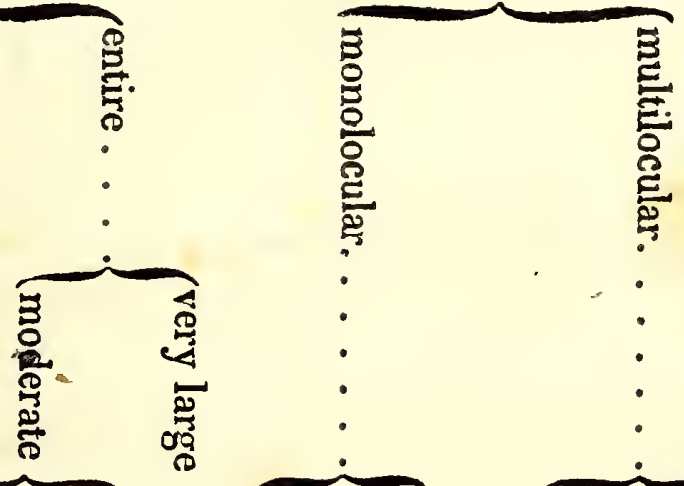

苜

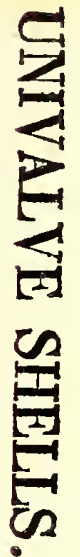

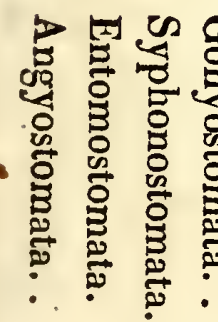
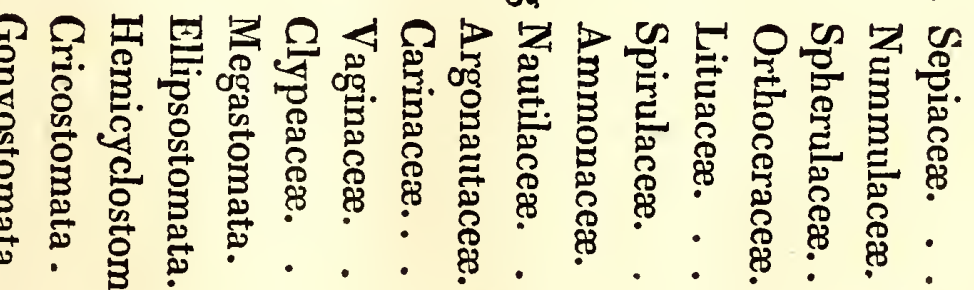

"ִ

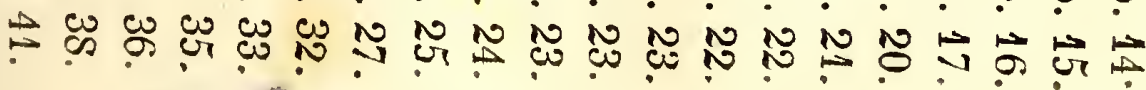




\title{
DIVISION 1. SEPIACER.
}

\author{
GENERA.
}

1. Loligo. lam. Galmar.

A plate of horn on the back, instead of a shell, in the form of a sword or lancet. Pl. 1, fig. 2.

2. SEPIA. Lam.

Shell oval, thick, gibbous; composed of an infinity of very thin calcareous plates, parallel, joined together by innumerable little hollow columns. Pl. 1, fig. 1 (1).

V. Animal, p. 54 .

V. Animal, p. 54.

(1) Being friable, from its structure, it is employed to polish variotis substances; it is also given to young birds to sharpen their beaks. 


\section{DIVISION II. NUMMULACE}

GENERA.

1. Nummbla, Lam, GaMERINA. Brug.

Exterior form lenticular, without any apparent opening; a spiral cavity divided by septa into an infinity of small chambers (1).

a. Perfectly discous. Pl. 1, fig 3, 4. (2)

Only one row of chambers to each turn of the spire.

The edge with blunt or sharp rays. $\mathrm{Pl} .1$, fig. 23 .
Marine.

Fossil and living. b. (Siderolites, Lam.)

c. (Renulites, Lam.)
Several rows of chambers to each turn of the spire.

Microscopic.

2. Disconbress. (3) Lam.

Spiral, all the turns visible and exposed. (4) Pl.

No siphon. 1 , fig. 5 .

(1) The Nummulites are amongst the most widely-spread fossils, forming, al most exclusively, entire chains of calcareous hills and immense beds of building stone. The Pierre de Laon is composed of Nummulites; the pyramids of Egypt were constructed with stone of this nature, and are raised upon the rocks which supplied it. They were formerly considered, by some, to be Lusus Natura, by which portions of calcareous matter assumed the form of organised bodies; by others, as petrified seeds, opercula, bivalve shells, etc. etc. Breynius, in 1732, and Gesner, in 1758, concluded them to be univalve shells, very analogous to the $\mathrm{Am}$ monites. Bruguiere thought that the animal was contained in the last chamber of the shell. Cuvier considers them to be interior shells. To observe the chambers more distinctly, let a drop of ink fall on the worn face, and when it is quite dry, rub the Nummulite delicately on a stone to take off the exterior black, after which all the points which have retained the ink become evident on a white ground, and the interior organization is perfectly discovered. This practice is useful for recog nising several other delicate fossil shells.

(2) These are the most common and the largest amongst the fossil species, but the living species are very small.

(3) The termination iles distinguishes the Genera exclusively fossil, no analogous living species having been yet discovered.

(4) This character distinguishes them from the Spirolinites, the absence of the siphon from the Nautili. 


\section{DIVISION III. SPHERULACEAE.}

GENERA.

1. Miliola. Lam.

Oval, globulous, or oblong; subtrigonal; the spiral turning around an axis perpendicular to the planes of the turns; divided into 2 or 3 chambers, the last pierced by a lateral hole, which is the only aperture. Pl. 1, fig. 6.

\section{Pollontes. Montf.}

Resembling the Miliola, but the chambers pierced alternately towards both ends of the shell, and

With chambers.

\author{
Marine. Some species \\ found on Fuci, in the \\ neighbourhood of Cor- \\ sica (1).
}

the last open the whole breadth. Pl. 3, fig. 16.

3. Arethusa. Montf.

Chambers rolled obliquely (making the shell turreted) and only the last perforated. Pl. 3 , fig. 17.

\section{Melonites. Lam.}

No apparent mouth; consisting of numerous Without chambers. tubes or siphons united in a plane rolled on itself. Pl. 2, fig. 1.

\section{Gyrogonites. Lam.}

Hollow spheroids, composed of several linear pieces, curved, joined at the sides, the extremities terminating in the poles; the surface furrowed in transversal circles (2). Microscopic. On the shores of the Adriatic.

On the shores of the Medilerranean Sea and Indian Ocean. Pl. 1, fig. 14.

(1) The fossil species have formed, exclusively, immense beds of stone, especially in the quarries of the environs of Paris.

(2) Only one species known, the size of a pin's hcad, G, medicaginula, Lam. 


\section{DIVISION IV. ORTHOCERACEÆ.}

GENERA.

1. Belemnites. Boet. de

Boot.

A thin double case, A siphon extending Very abundant, escomposed of two cones from the summit of the pecially in strata of united at their bases; exterior to the same part Chalk and Compact the interior cone much of the interior cone, Limestone. shorter than the other, whence it continues eidivided within by paral- ther along the edge or lel septa, concave towards through the centre of the the base; only one cham- septa.

ber (conical) apparent, the older ones being successively effaced by the piling up and contiguity of the septa. Pl. 1, fig. 9, 22, etc.

a. Elongated in cylindors, sharpened at the end only.

b. Narrowed towards the base, like a distaff or lance.

2. Orthoceratites. Brey. nius.

Straight or slightly bent; chambered; margins of lateral.

the septa even, or with 1 or 2 small undulations. Pl. 1, fig. 25. Pl. 2, fig. 11.

\section{Conularites. Miller.}

Concave, hollow, mouth half closed by an inflexion of the lip. Pl. 3, fig. 19,21.

Septa imperforate.

In Transition Limestone, in Ironstone, in Schale, with marine shells.

4. Amplexites. Sowerby.

Nearly cylindrical; divided into chambers by numerous transverse septa embracing each other with their reflected margins. Pl. 2, fig. 10.

5. Nodosaria Lam.

Straight, chambered, slender, with a contraction at each septum.
In the Limestone of the Black Rock at Limericḱ.
Said to characterise the Transition Rocks of Werner.
A kin to the Raphanister(Pl.2, fig. 15)', Echidnus (Pl. 2, fig. 14), and Telebois (PI. 3, fig. 22) of Montfort? 
a. Contractions moderate. Pl.2, fig. 9.

6. Contractions so deep that the septa are united by the siphon only and appear as if strung together. Pl.2, fig. 12 .

\section{Hippunites. Lam. Con-} NU-COPIE. Thomeson.

Thick, cylindrical or conical, with irregular septa traversing two longitu-

A siphon, a gutter instead of a siphon, or both.
Several large species in the older Secondary Mountains.

dinal cylindricál projections adhering to one of the sides; mouth closed by an operculum. Pl. 1, fig. $21,26,28,31,33$. Pl. 2 , fig. 18.

a.

Conical, more or less arched. Pl. 1, fig, 21.

b. Batholites, Montf. Straight, cylindrical.

\section{Baculites. Faujas. $\mathrm{H}_{\mathrm{A}}$ -} MITES. Parkinson.

Straight, cylindrical, a litttle conical, fusiform, hooked or bent, compressed : septa transverse, undulated at the margins. Pl. 1, fig. 17, 19. Pl. 2, fig. 16. Pl. 3, fig. $18,23$.

a. With a siphon at the outer edge of the chambers.

b. Without

\section{8. 'Turrilites. Montf.}

Spiral, turreted: with chambers divided by sinuous septa: the turns contiguous, all visible : mouth round. Pl. 1, fig. 16. disks.

Septa pierced in their Maestricht. In the
clay at Folkstone. In
the chalk at Hamsey and
at Horton. 
both on fracture, Pl.1, fig. 8. pl. 2, fig. 7 : it does not appear, however, that he thought of making a longitudinal section of the Echinus, such as $M$. Beudant has submitted, pl. 1, fig. 8. pl.2, fig. 8. A Belemnite, in the collection of the Conseil des Mines, which has not entirely passed into the calcareous state, presents in some of its parts the same spongy and radiated tissue which we observe in the spines of the Echinus. This Belemnite also offers the peculiarity of a nipple at the base, with projecting sidcs, striated transversely, and diverging from the centre to the circumference; the centre is perforated by a small shallow round hole: the summit sometimes terminates in folds. Pl.1, fig.10, 11,12. Some present a large conical cavity at the base, which has been often considered as the last chamber or dwelling of the animal; others have none, or at least a very small cavity. Theophrastus's description of the lynx stone is not applicable to the Belemnite : it would seem that we owe the first notice of it to Pliny, but it is not quite clear whether his dactylus idaus $(1.37$, c. 10) which he clearly distinguishes from the lynx stone (1. 8, c. 38) was a fossil species of Echinus or Belemiite. In the 15 th century they were considered to be meteoric stones, and marvellous medicinal virtues were ascribed to them. Boetius de Boot, in his Treatise on Stones, pronounces them to be petrified darts, and it was not until the end of the 16th century that they were first regarded as natural organised bodies. Erhart, in 1724, appears to have been the first who concluded them to be shells akin to the Nautilus. Deluc insisted that the Belemnite was an organised bone, like that of the Sepia; and they have been concluded by other authors to be stalactites; petrified wood; the teeth or the back bones of fish; the tusks of the Narwal; Grocodile's teeth; tubulites, etc. etc. Cunier, Régne Animal, t. 2. p. 371. Sage, Jour. de Phys. ventose. an. s. Beludant, Observations sur les Belemnites. Ann. du Mus. t. 16. p.77. Faure Biguet. Considerations sur les Belemnites, etc. Lyon, 181.9 .

\section{Orthoceratites.}

Mr. Farey "finds them referable to twenty different places in the British series of strata; extending from (1st) the London clay above the chalk, to (20th) the limestone resting on slate." According to Spallanzani, the islands of the coasts of Dalmatia are masses of orthoceratites. M. Sage thinks, from the sections he has made, pl.1, fig. 24, that the Orthoceratites are alveoli of different species of Belemnites, and contained within the funnel, pl. 1, fig. 29, which, however, according to M. Beudant, does not always exist. This opinion has not been generally'adopted. Deluc, in particular, combated it (Journ. de Phys. vent. an. 12.), asserting that the alveoli of the Belemnites have no siphon. M. Sage considers the organization of the siphon to be evident in pl. 1, fig. 27, and in the centre of fig. 25, vihich is confirmed by Platt and Beudant: Montfort seems to have vicwed the alveoli as the envelope of a parasite. Breynius submits fig. 30 as an orthoceratite, with the siphon passing through the axis; fig. 35 , as the convex front of the last articulation, with the siphon, of a species found most frequently in the marble of Oeland, on the coast of Sweden, four feet long, and only two inches in diameter at the base; fig. 34 , or the same part of another species, whose diameter is three inches, whence he infers its length to be more than five feet; fig. 11, p. 2, is that of a species from Gothland, with a large siphon at the circumference, and remarkable for the projecting rays, sometimes filled with crystals of fluor, the proportion between the length and the diameter appeared to be $10: 1$. Disscriatio Physica de Polythalmiis. Gedani, 1732. Some are smooth, others have circular sides; both kinds are found in the greyish marble of Norway; they are of a whitish calcareous spar, with a case or envelope of a reddish brown; the chambers are separated by hemispherical yellowish lines.

\section{II ippurites.}

Some consider what we call the operculum to be the last scplum, in which case the shell may be interior, unless it is hereafter discovered to be a bivalve: fig. 26 , part of a convex opcrculuni, with two prolongations having the appearance of a 
hinge; whether this is natural or accidental to the petrifaction cannot be decided, for no other example is known amonst the various species which have been found; fig. 31 is a Hippurite, with a gutter, a, and a siphon, b; its surface is smooth and the septa are concave : fig. 33 is one of the most singular species which have yet been discovered; the operculum is entire, and pierced with two eyes; it is only six lines in depth and fifteen in diameter: fig. 18, pl. 2 , found in a considerable bed on the mountain of Montforrand is sometimes a foot and a half long, the diameter not exceeding an inch; the operculum has been destroyed by long exposure; $M$. de la Peyrouse observes, that their situation in the rock clearly indicates that they have been petrified in the same position and in the same place in which they had originated. De novis quibusdam Orthoceratitum et Ostracitum speciebus Dissertatiuncula, Erlangx, 1700. Dr. Thomson, formerly Professor of Anatomy at Oxford, saw several species in the cabinet of M. Chiarelli, at Palermo, in 1789, in the form of the femur of a cow or. horse, which had been found entire at Cape Passora (the ancient Pachynus), with no bones whatever in their neighbourhood. Dr. Thomson, on visiting the spot expressly, could only meet with species in the form of a case or sheath, and equal in dimension to the horn of a bull about three years old; the interior hollow, and containing two cylindrical bodies, like two candles. The base of this cone is closed by a species of lid, similar to that of a powder horn. The internal structure resembles a heap of egg shells, broken transversely, and piled up so as to touch each other, but leaving a void space in the middle. These plates are so flexible that they allow the concave part of the horn to bend inwards when squeezed. Their disposition has some resemblance to the diaphragm of the buman body. The Hippurite, therefore, is not entirely divided into concamerations, and has no tubes of communication, or siphons, as we find in the Ammonites, Belemnites, and Orthoceratites. The texture of this case, as it exists in a fossil state, is scaly lengthwise and across. The transversal fracture, when it is fresh, appears to be strong, and composed of concentric layers; but after having been some time exposed to the air, this fracture appears rotten and spongy, so that in the part changed by the air, it becomes ramified like an animal substance, which gives it the appearance of a bone. This fossil case is closed by an operculum, the internal surface of which is imbricated in converging rays, like the shell of the Pecten. The thickness of the operculum led Dr. Thomson to conclude that this case was inhabited by one animal only, and that it was not the nest of several.

\section{DIVISION V. LITUACEE.}

\section{GENER $\Lambda$.}

1. Lirtuus. Breynius.

The last turn elongated.

a. Lituites, Montf.

b. Hortolus, Montf.

2. Scaphites. Parkinson.

The last turn (after being enlarged and elongated) diminished and reflected inwards. Pl. 2 , fig. 6 .
Turns contiguous. Pl. 1, fig. 7.

Turns separated. Pl. 1, fig. 32 .
China: Foss, in the red limestone of Oeland; Meudon; in the limestone at Namur.
In the London lcay; Crag Marl ; Melbury Marble. 
DIVISION VI. SPIRULACEA.

GENERA.

1. Spirula. (1) Lam.

The turns of the spire not touching; divided transversally into chambers. Pl. 1, fig. 18.

\section{SPIRolinites. Lam.}

The turns of the spire touching; the septa projecting in a small degree, so as to divide the exterior surface of the spire by crests or strix. Pl. 1, fig. 13.

\section{Ammonocehatites. (3)} Lam.

Septa numerous, undulated at the margins. Pl. 3, terior.

Siphon traversing the septa and chambers.

Siphon occupying the Austral Seas. Gulph middle of each chamber of Florida. V. Animal, and continued to the ex- p. 54.

tremity of the shell. fig. 14.

(1) Peron's discovery of the animal of the Spirula, so nearly akin to the Nautili that Linnæus placed it amongst them, has thrown much light on all the multilocular univalves : thitherto, it was a question whether the animal inhabited the last chamber of the shell; whether it was contained entirely or partly within it; or whether the shell was enveloped more or less completely by the animal. The animal of the Spirula is perfectly analogous to the Sepia, and its shell is enchased in the posterior extremity of the body, and only visible in part. There is now very little, or no doubt, therefore, that the Rotalites, Belemnites, Hippurites, etc etc. were more or less enchased in the posterior extremity of the animal, a portion of whose body was enveloped in the last chamber and connected, probably, by a tendinous filament inserted at the extremity of the siphon, similar to that of the Nautilus. Breynius, on the authority of Woodward (Catalogue of English Fossils. Part I, p. 113), says, that the shells of the Spirula abound on the shores of Jamaica, Barbadoes and the Baharnas : he adds, "de figura autem animalculi domicilium hoc testaceum curiosissimum inhabitantis, altum apud omnes silentium." p. 22.

(2) Lamarck has mentioned the genus Cristellaria (Pl. 3, fig. 13), but without defining it, and there are none in the Museum. These shells are cretaceous, and almost microscopic. Fossil species, pyritous ur ferruginous, are found in Tuscany; and M. Defrance possesses others, which are said to have been brought up with the soundings off Teneriffe.

(3) The locality is unknown. M. Lamarck purchased it by accident: he kindly allowed me to take it home. in order that the figure, which is the first that has been made, might be as accuratc as possible. 


\section{( 22$)$ \\ DIVISION VII. AMMONACEIE.}

GENERA.

1. Ammonites. Brug.

Scpta of the chambers A siphon, generally Abounding in the Seundulated at the mar- marginal. condary Mountains, gins. (1) from the size of a pin to that of a coach-wheel.

a. Ammonites, Lam. All the turns visible. Pl. 1, fig. 15.

6. Orbulites, Lam. The last turn enveloping all the others. Pl.3, fig. 11, 12.

(1) Aceording to Spallanzani, there are vast beds of Ammonites in the environs of Nevers. They have been found in England, in all the formations from the 1st or alluvium, to the 8th or first sand stone, inelusive.

\section{DIVISION VIII. NAUTILACEA.}

\section{Niutilus.}

\section{GENERA.}

The last turns of the Septa numerous, simspire not only touch but ple, transverse, siphunV. Animal, p. 54 . envelope the preceding. culated. P1. 2, fig. $2,3,4$.

a Nautiures. (1)

\section{$\$$ Microscopic.}

a Lenticulina, (2) Lam. The last turn, as in the existing specics; pl.2, fig.17. One siphon. $f$ in the middle of the septa.

Scveral siphons... $\left\{\begin{array}{l}\text { towards the edge. } \\ \text { scaitered. } \\ \text { ranged in a longitudinal line. } \\ \text { ranged in a transversal line. }\end{array}\right.$

A slit, instead of a siphon .. $\begin{aligned} & \text { longitudinal. } \\ & \text { transversal. }\end{aligned}$

B Rolalites. (3) Lam. The mouth placed more on one side than the other, or entirely on one side, pl. 2, fig. 13.

$\gamma$ Diseorbites. (3) Lam. All the turns visible, pl. 1, fig. 5.

$\delta$ The last turn very large in comparison with the rest of the spire.

SS Large or moderate.

a Anguites. (4) Montf. One siphon.

$\beta$ Bisiphites. Montf. Two siphons.

y Planulites. Lam. Siphon towards the edge.

$\delta$ Ellipsolites. (5) Montf. Spire elliptic, pl. 3, fig. 15.

4 Amaltes. Monif. Siphon in the middle.

(1) Foss. in the London Clay; Crag Marl; Chalk Marl; Green Sand ; Under Oölite; Blue Lias; Derbyshire Peak or Mounlain Lime Stone.

(2) Foss. at Senlis; Soisson; Grignon; Meudon. Lamarck possesses Lenticulina in the recent state which were found in 125 fathoms off Teneriffe.

(3) Foss. Grignon.

(4) Foss. Grignon. Defrance has received specimens in the recent state from New-Hoiland and the Red-Sca.

(5) Foss. in the Derbyshire Peak Lime Stone. 


\section{DIVISION IX. ARGONAUTACEA.}

\section{GENERA.}

1. Argonauta.

Very thin ; the last turn so disproportionately large as to give the spire the appearance of the poop of a ship. Pl. 13, fig. 4 .
Mediterranean. Atlantic. Fossil species between Rouen and St. Ouen (Pl. 3, fig. 9), and at 'D'Anvers. $\mathrm{Y}$. Animal, p. 55 .

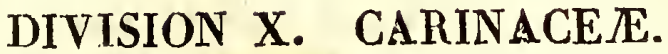

\section{GENERA.}

\section{Garinaria. Lam.}

Conical, flattened at the sides. The summit an involute and very small spire; the back with a keel.

dentated keel: very thin.

Pl. 5, fig. 16.

\section{DIVISION XI. VAGINACER.}

\section{GENERA.}

\section{VaGrnellitrs. Daudin.}

Tubular, oblong; thin and pointed at one end, and an enlarged mouth at the other. PI. 3, fig. 10.

\section{Gleodora. Peron.}

Cartilo-gelatinous; like a reversed truncated pyramid. Pl. 5, fig. 2.

A superior but no lateral aperture.
Mouth entire, oval, oblong, narrowed to- lantic, Indian Seas. wards the angle of the V. Animal, p. 72.

\section{Cymbulia. Peron.}

Cartilo-gelatinous, very transparent, crystalline, oblong, like a truncated sabot or boat. Pl. 5 , fig. 3 .
Aperture lateral and anterior.
In the interior of the fossil shells of the environs of Bourdeaux.

\section{Hyalea. Lam.}

Horny, oval-globulous; ......... Mediterranean, Attridentated posteriorly.PI. 5 , fig. 1.

Seas of warm climates. V. Animal, p. 56 . Nice.

Mediterranean, near V. Animal, p. 56. lantic, etc. V. Animal, p. 56 . 


\section{( 24$)$}

\section{DIVISION XII. CLYPEACEÆ.}

\section{GENERA.}

\section{Patella. (1) Lin.}

Oval or almost orbicular, in dilated cones, more or less obtuse and concave beneath. Pl. 5, fig. 5, 6 .

Mositly marine, adhering to the rocks and other hard substances bordering the sea.

V. Animal, p. 73.

2. Fissurtelia. (2) Lam.

A small hole at the Marine. V. Animal, summit. Pl. 5 , fig. 10 . p. 72.

3. Emarginula. (3) Lam.

4. Scutus. Montf. PAR-

A notch at the poste- Marine. V. Animal, rior edge. Pl. 5, fig. 11. p. 72.

\section{MAPHORA. Blainv.}

Elongated, flattened ; summit apparent towards the posterior part, which is rounded; the anterior truncated. Pl. 5 , fig. 4.

\section{Septaria. Feruss. \\ NAVicella. Lam.}

Summit symmetrical, inclined towards the posterior edge : an operculum. Pl. 5. fig. 23.

6 Ancrlus. Geoff.

Conical.

a. Pl. 5, fig. 7.

b. Plectrophorus, Fer. With an interior winding

A horizontal plate within.

Marine. New Zealand. Fossil species at Grignon. . Animal unknown. impression. Pl.6, fig. 2,3. Teneriffe. Maldives.

(1) The animal of the fresh-water Patella differs from that of the marine, although the shell has scarcely any distinguishing character. The fossil species P. cornucopia (pl. 5. fig. 6.) resembles a cap, and is of considerable thickness. Foss. in Alluvia; Crag Marl; Chalk Marl; C'lunch Clay; Alum Shale of Whitby; Forest Marble.-Grignon; Houdan; Pontoise.

(2) Foss. in the beds of coarse marine limestone at Grignon, and in the marl-pils of Touraine.

(3) Foss. in Limestone analogous to that at Grignon. 


\section{DIVISION XIII. MEGASTOMATA.}

GENERA.

A. In the form of a shield or cap.

1. Capulus. Mont $f$.

Conical, the summit curving spirally. Pl. 5, fig. 13.

Marine.

Mediterrancan. Barbadoes.

V. Animal, p. 71.

2. Hipponyx. (1) De France.

Conical, summit in- Support adherent and Marine. clined backwards. Pl. 6, bearing (as well as the fig. 1. shell) a muscular impression in the shape of a horse-shoe.

3. Crepidula. Lam.

Oval or oblong, the Half closed by a hosummit obtuse, inclined rizontal plate. towards the edge. Pl. 5, fig. 12.

\section{Cialyptran. (2) Lam.}

Conical, the summit vertical and pointed.

Marine.

On the rocks of the Caribbean Sea. Mediterranean.

V. Animal, p. 72.

Marine.

Atlantic, Indian Seas.

a The platè (adhering to the bottom of the cone) folded, and descending vertically. Pl. 5 , fig. 8.

$b$ Infundibulum, Montf. The plate simple, almost horizontal, adhering to the sides of tbe cone, which has a spiral line on the exterior. Pl. 5, fig. 20.

\section{UMrRella. Lam.}

Orbicular, slightly con- Acallous, colored disk, vex above, a small apex within. near the summit. Pl. 5, fig. 15.

Marine.

Mediterranean, Indian Seas.

(1) Several valves of different sizes having been found at Grignon, in the marlpits of Hauteville, Montmirail, etc. they were considered by some naturalists as the type of the genus Acardo. M. Defrance having remarked a similar support adhering to a recent shell (Patclla mitrata, Gm.), foresaw that some other Patella were to be separated from that Genus to form the present. His conjectures were afterwards realised by finding one of the fossil species on its support.

(2) Foss. Grignon.

(3) Foss, in the London Clay; Craor Marl; Woolwich Loam; Grocn Sand. 
B. In the form of an ear.

7. Halyotrs. Lam.

Spire or spiral apex flattened, excedingly small.

Marine.

a. Halyotis, Lam.

Pierced by a series of holes. Pl. 5, fig. 24.

\section{b. Padolla, Montf.}

A deep furrow within, forming a ridge without. PI. 6 , fig. 4 .

c. Stomatia, Lam.

Spire more prominent; shell deeper. $\mathrm{Pl} .5$, fig. 21.

d. Stomatella, Lam.

Whorls carinated. Pl. 5, fig. 22 .

\section{Sigaretus. Adans.}

Ditto; mouth very deep; shell hidden within a spongy buckler. Pl. 5, fig. 25.

\section{Testacella. Lam.}

Oval, spire very small ; semi-corneous, transparent. Pl. 5, fig. 9. Pl. 6, fig. $7,8,9$.

\section{Parmacella. Cuv.}

Oblong, flat, with a slight commencement of a spirc behind. Pl.6. fig. 10.

\section{Vitrina. Draparn.}

Heligo-limax. Feruss.

Very thin, transparent, flattened. Pl. 5, fig. 14.
Almost all the holes obliterated.

No holes.

No holes.

Seas of warm climates.

V. Animal, p. 71.

Terrestrial. South of France. Teneriffe. V. Animal, p. 61.

\section{T'errestial, Mesopo- tamia. \\ V. Animal, p. 61.}

The mouth (diminish - Terrestial. Those of ed by the projection of Europe live in humid the penultimate whorl of places and are very the spire) in the form of small; those of warm a crescent, broader than climates are larger. deep.

(1) They are found on the coasts of Brittany, Asia Minor, Barbary, Western Africa, India, New Holland, New Zealand, and California. Luid and Scheuchyer report that they have found the Halyotis in a fossil state. Bertrand, in his Dictionnaire Orictolo gique, says that be possesses a shell of this Genus, brought from Virginia, resembling a ferruginous stone. 
 \\ DIVISION XIV. ELLIPSOSTOMATA. \\ GENIRA. \\ A. Longitudinally volute; the last whorl considerably larger than}

the preceding.

1. Lymazus. (1) Lam.

Spire oblong; thin; no operculum. P1.6, fig. 12.

2. Physa. Drap.

Spire short or moderate; very thin; no operculum.

Columella* with a longitudinal fold entering obliquely into the mouth.

Columella simple.

In springs. V. Animal, p. 63. Pl. 6, fig. 13.

3. Melania. (2)

Outer lip advancing and narrowing the mouth; an operculum.

a. Melania, Lam.

Peristoma complete, effusive (3) at the base of the columella; black. Pl. 6, fig. 14.

b. Melantho.

Peristoma incomplete, not effusive; very thick : white. Pl. 6, fig. 15.

c. Melanopsis, Lam.

Peristoma incom. plete, inner lip very broad, reflected, effusive; black. Pl. 6, fig. 18.

d. Melanella, Dufresne.

Semi - transparent, mouth invaded by the last whorl; white. Pl. 6 , fig. 17 .

(1) Foss. in the Cowes Roch of Limestone; Grignon; 1st and 2nd Fresh Water Formations of the environs of Paris. * $\quad$ See the section Pl. 12, fig. 16.

(2) I have ventured to separate the marine Melanix, under the name of Melantho, the Melanella (in the eabinet of M. Dufresne), and the Mclanamona; adding the name of Melanatria to Lamarck's Pyrene, in order to indicate its connexion with the others. Foss. in the London Clay; Purbeck Limestone; Coral Rag ; Blue Lias; at Grignon, Courtagnon, Houdan, Parnes and Ponchartrain. The fussil species of Melania found at Grignon differ remarkably from the fresh water species. In the $M$. costellata, pl. 13, fig. 14, the peristoma is continuous, but the mouth is not circular, and it is entirely detached from the eolumella towards the upper part of the lip. In the M. cochlearella, $\mathrm{pl} .13$, fig. 13, the lip is prolonged like a spoon; in the M. marginata, pl. 13, fig. 10, the peristoma is margined or thickened. The fluviatic Melunia brought by Olivier from the East are very distinct in appearance from all other species: see Pl. 8, fig. 14, 17. This Genus is, probably, entirely foreign to Europe.

(3) Versante is the French term, which they explain by saying if the shell were laid on its back and filled with water, it would run out at this part of the mouth: this has been coneluded to be the meaning of Linnæus's term Effusus, but it appears improbable that he should take a perfect instead of a present participle, when we consider his Latinity. 
c. Melanamona.

Effusive, with one very deep sinus; black.

Turreted.

Fluviatic.

Pl. 6, fig. 19.

f. Melanatria. Pyrene.

Lam.

With 3 undulating

sinuses : black. Pl. 6 ,

fig. 20 .

4. Phasianelia. (1) Lam.

Oblong : operculum, Columella simple, flatcalcareous. Pl.6, fig. 21. tened at the base.

Marine. Indian Scas. Shores of New Holland. V. Animal, p. 67.

5. Aur icuia. (2)

Oval or oblong, outer Columella, with large lip thickened. Pl. 6, fig. oblique channellings or 22. folds; no umbilicus.

Mostly Fresh Water, but some Marine.

V. Animal, p. 63.

\section{Scarabetus. Montf.}

Oblong-oval, spire a- Inner lip toothed, with cute; outer lip thickened, a hollow below the middentated. Pl.6, fig. 23. dle.

On herbs in the Moluccas. The marshes, woods, and mountains of Asia.

Animal unknown.

\section{Carychium. Muller.}

Oval or oblong, spire obtuse; outer lip thicken- hollow below the middle, ed, margined ; penulti- the upper part wanting. mate whorl much larger than the preceding, but considerably less than the last; no operculum. Pl. 6 , fig. 24.

8. Conovulus. Lam.

Melaupus. Montf.

An inverted cone; lip Columella with profinely striated; no opercu- jecting folds. lum. Pl. 6, fig. 25.

The Woods of Europe, under moss. St. Vincent's.

9. Achatina. (3) Lam.

Agathina.

Oval or oblong.

Columella trincated at the end.

Indies. T. Animal, p. 63.

Rivers of the West 
a. Liguus, Montf.

A callosity within the last whorl. Pl. 6 , fig. 26.

৮. Polyphemus, Montf.

The end of the columella curving inwards. Pl. 12, fig. 11 .

10. Bulimus. (1)

Oval, or oval oblong. Columella smooth.

On rocks and trees in cool shady places. Large species in warm climates. V. Animal, p. 62.

a Bulimus, Lam. Outer lip thick, blunt, pl. 6, fig. 27.

6 Bulimopsis, Lam. Outer lip thin, sharp, pl. 4, fig. 15.

c Bulimulus, Leach. Outer lip thin, sharp; inner lip inflected, pl. 6, fig. 28.

11. Amphibulima. Lam.

Succinea, Drap.

[ Elongated or oval ; spire, V. Auimal, p. 62 . short, of 2-4 whorls, the last forming almost the whole of the shell. Pl. 6, fig. 5, 6. Pl. 7, fig. 5, 6 .

12. Tornatelia. Lam. Acteon. Montf.

Spire projecting but lit- Columella with one or tle; mouth elongated, en- two large folds. larged below. Pl. 6, fig.

Marine.

Coasts of Africa.

V. Animal, p. 63. 29 .

B. Longitudinally volute; the last whorl wery little larger, or less, than the preceding.

\section{Guausilia. Drap.}

Slim, long, pointed; With or without teeth the last whorl contracted, or projecting plates.

compressed; mouth edged with a callous pad. Pl. 6 , fig. 36 .

(1) Fossil species have been found in the $2 d$ Fresh Water Formations of the environs of Paris. The marine species at Grignon have not the same generic character as the Bulimi, according to Brongniart, and ought to be referred to the Phasianellæ. Lamarck has observed that only terrestrial shells have the lip reflected. The Bulimus dombeyanus, B. octronus, and B. terebraster, pl. 13, fig. 15, and many other species which inhabit Asia, $\Lambda$ frica, or America, are turreted with numerous whorls; others are of a conical form, as the Bulimus trochoides of Bruguiere. See the singular species, and its monstrosity, Pl. 6, fig. 35. 31 . 


\section{Odostomia. Fleming.}

Spire produced; mouth contracled, subangular,

The greater number distinct from the body terrestrial; under stones, on rocks, and in mosses. whorl. Animal unknown.

a. Spire dextral. Pl. 8, fig. 28.

b. .. sinistral. Pl. 8, fig. 23.

\section{Pupa. (1) Lam.}

Summit obtuse; mouth narrowed by a callous pad, and diminished on the side of the spire by the preceding whorl. Pl. 6, fig. 37,

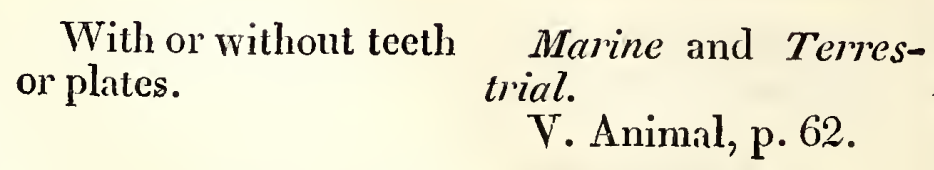
34 .

$$
\text { Cylindrical. }\left\{\begin{array}{l}
a \text { Without a tooth, pl. 8, fig. } 29 . \\
b \text { A tooth in the part of the mouth invaded by the penulti- } \\
\text { timate whorl, pl. 8, fig. } 32 . \\
c \text { Teeth within the outer lip, pl. 6, fig. } 37 .
\end{array}\right.
$$

Oval. $\left\{\begin{array}{c}d \text { Chondrus, Cuv. Teeth at the lip, or plates within the mouth, } \\ \text { pl. } 8, \text { fig. } 24 .\end{array}\right.$

\section{Horizontally volute; mouth transwersally elliptical.}

\section{Planorbis. (2) Brug.}

Rolled almost in the same plan ; the whorls increasing gradually ; no opcrculum. Pl. 6, fig. 32.

\section{Helix. (3)}

Globulous or subconical, spire depressed; mouth somewhat diminished by the projection of the penultimate whorl. Pl. 7 .

(1) The shells of the marine and terrestrial Pupæ are similar, but an experienced Conchologist may always distinguish them : the animal of the former is not known. Lamarck doubts the Pupa mumia to be marine. Foss. in the $2 d$ Fresh Water Formation.

(2) Fossil species have been found in the Limestone of Fontainebleau ( $2 d$ Fresh Water Formation); in the Silex ncar Paliscau (2nd Fresh Water Formation); in the Marne Blanche covering the Gypsum at Pantin and Chaumont (1st Fresh Water Formation); in the Cowes Rock of Limestone; London Clay; Green Sand; Under Oolite; Derbyshire Pcak Limestone. Neither of the three Planorbes cited at Grignon can be exactly referred to this Genus; the Carinata resembles the Delphinata.

(3) The distinction of fresh water formations, so precisely established by Geologists, has made it indispensably necessary to study this Genus attentively. An arrangement with a view of easily distinguishing the species is difficult, from the great accumulation, for whilst the shells present the greatest varieties of form, the. animals offer no differences of any importance. As M. de Ferussac appears to have studicd the excessively numerous species of this Genus more completely than any other author, accompanying the publication of his system, whîch comprcbends all the known species, with accurate and beautiful engravings, I shall adjoin his 
a Helix, Lam. Globulous, pl. 7, fig. 9.

$b$ Caracolla, Lam. Carinated, conical, pl. 7, fig. 22.

c Anostoma, Lam. Mouth dorsal, toothed, pl. 7, fig. 20.

18. Helicina. (1) Lam.

Subglobulous or conical ; spire a little depressed; inner lip enlarged at the base in a callous pad entirely covering the um. bilicus ; a small blunt angle at the base of the right lip. Pl. 12, fig 6 .

19. Helicarion. Ferruss.

Very thin, transparent.

20. Ampuldaria. (2) Lam.

Round and ventricose, spire short; umbilicate; operculum horny.

a.

Mouth narrower, more elliptical, thinner. Pl. 9, fig. 1 .

6. Ampullina.

Considerably thicker. Pl. 9, fig. 2 .
Columella callous.

Terrestrial. V. Animal, p. 66 .
Columella spiral, solid, formed by the inner lip and confounded with the whorl of the mouth.

\section{Columella umbilical.}

Marine.

Australasia. V. Animal, p. 62 .

method of distribution, impressing that it is purely artificial. The Helices being terrestrial shells, it appears extraordinary that we should meet with them in the fossil state in marine deposits; but when that happens they have been brought there by floods or rivers, or by some irruption of the sea, attesting that previously to these deposits there had been dry land in the same places, whereon the animals lived which formed the shells. The Marl Pit of Touraine is the only place on record where they thus occur, and there they are frequeutly filled with the remains of Polypi and marine shells. Fossil Helices are generally found in Frcsh Water Formations, and often accompanied by Lymnxi and Planorbes. We meet with them in breccia, and sometimes in the districts which have been overthrown by volcanocs. In England they have been found in the Cowcs Rock of Limestone, in the Green Sand, and in the Derbyshire Peak Limestone.

(1) Foss. Blue Lias Limestone.

(2) Their opercula, being horny, are never found, although these shells are very common in beds of coarse, calcareous, shelly matter; whilst the opercula of the Natica, to which some authors would refer them, are very frequently met with, from their being calcareous. Fossil Ampullarix are also found in the cxtinct volcanoes of the valley of Ronca, where they have been so disposed by the eruptions as to preserve their colours. M. Faujas found a species of Ampullaria, with a very thick shell, at St. Paulet, near Pont St. Esprit, in bituminous marl, above a mine of fossil coal; the upper edge of each whorl bears an ascending keel, and it differs from all that are known, by an oval mouth, pl. 12, fig 12,13,14. 


\section{DIVISION XV. HEMICYCLOSTOMATA.}

\section{GENERA.}

Nrrita, Lin.

Semi-globulous; mouth Columella in a straight semi-circular or semi-el- line.

liptical, closed entirely by an operculum; spire almost effaced.

a. -Natica, (1) Lain.

Operculum horny. Columella umbilicate. Pl. 9, fig. 24.

b. Nerita, (2) Lam.

Operculum stony, Columella umbilicate, Marine. shell thick. Pl. 9, fig. dentated. 20.

V. Animal, p. 67.

e. Neritina, Lam.

Operculum horny, Columella rarely den. shell thin. Pl. 9, fig. tated. (3) 21.

(1) In the fossil state, in the London Clay and Crag Marl; at Grignon.

(2) In the fossil state, at Retheuil, Courtagnon, Houdan, Grignon.

(3) Those with the columella dentated form the genus Clithon of Montfort, whose Clithon corona, pl. 9, fig. 23, differs from the Clithon coronata of Leach. 


\section{$(33)$ \\ DIVISION XVI. CRICOSTOMATA.}

GENERA.

1. Turbo. (1) Lam.

Round or oval; thick. $\begin{gathered}\text { Mouth completed by } \\ \text { the penultimate whorl. }\end{gathered}$ V.Animal, p. 65.

a. Meleager, Montf. Umbilicate. PI. 9, fig. 3.

b. Turbo, Montf. Not umbilicate. Pl. 12, fig. 15.

2. Turritella. (2) Lam.

Spire elongated like an obelisk ; thin horny or cartilaginous. PI. 9, fig. 12. Pl. 12, fig. 17.

3. Vermicularia. Adanson.

Whorls not touching, irregularly curved. Pl.9, fig. 17.

Ditto.

\section{Delphinula. (3) Lam.}

Thick; rolled almost in Mouth entirely formed the same plane. Pl. 9. fig. by the last whorl. 16.

\section{Scalaria (4) lam.}

Turreted, with projecting sharp longitudinal ribs. Pl. 9, fig. 6 .

Ditto; but margined.

Marine.

V. Animal, p. 65

Marine.

V. Animal, p. 65 .

\section{Aciona. (5) Leach. W ENDLETRAP.}

Ditto, but whorls dis- Mouth entire and martinct and distant; no co- gined. lumella. Pl. 9, fig. 5,

Marine.

Animal unknown.

(1) Foss. in the Crag Marl; at Presles; Grignon. No fossil species of this genus has been discovered in the Fresh Water Formations; the little shell of the ponds of Havre and Magentone have been erroneously referred to it.

(2) Foss. in the London Clay; Crag Marl; at Grignon, Chaumont.

(3) Foss. Grignon, Courtagnon.

(4) Foss. in the London Clay; Crag Marl; at Grignon, Presles.

(5) " The museum of Mr. Bullock contains the largest known specimen of the Aciona Scalaris, which was purchased at a sale for twenty-seven pounds; but it is now estimated at worth more than double that sum."-Leach's Zoological Mis. ccllany, vol. 2.1815. 
7. Grclostoma. (1) Lam.

Oval - spiral, mouth round or ncarly round, closed entirely by a round, thin, calcareous operculum : peristoma complete. Pl. 9, fig. 13, 14.

\section{Valvata. Muller.}

Rolled almost in the same plane. Pl. 9, fig. 22.

\author{
Mouth bordered by a Terrestrial and aqua- \\ lic. \\ V. Animal, p. 66.
}

9. Paludina. (2) Lam.

Vivipara. Montfort.

Oval-spiral ; operculum with an angle like that of the mouth. Pl.9, fig. 15.

Mouth with a small Marine, and in stagangle towards the upper nant waters.

Fresh waters.

V. Animal, p. 66.

V. Animal, p. 66.

Marine.

V. Animal, p. 66.
Oval, or conical ; operculum round, horny. Pl. 9 , fig. 25.
A blunt and slightly projecting tooth at the base of the columella. Base flat or concave.

(1) Young $C y$ clostoma may sometimes be confounded with the shell of the genus Turbo; for the upper part of the peristoma is not completed, that is to say, the lips do not join, before the adult state; in the Turbo they always remain separated. The Missenau chain of hills near Mayence is composed of fossil Cyclostomx, not of Bulimi, and of two species which, according to M. de Ferussac, are again found in Quercy, Agenois, and in Silesia. M. Brongniart expects that the Cyclostomx will hereafter be divided into two genera; the one aquatic, the other terrestrial. The C. mumia, Lam. pl. 4, fig. 1, belongs to the latter ; it has only been found as yet in the 1st or Lower Fresh Water Formation in the en virons of Paris; M. Brongniart conceives that on further investigation it may be found to characterise it: the enlargement or projection of the upper part of the peristoma is uot unfrequent in the living species. All those indicated at Grignon differ from true Cyclostomæ. The Cyclostoma carinata of the canals of Egypt, Pl. 13, fig. 9; C. bulimoides of the environs of Alexandria, Pl. 8, fig. 13; C. unicolor, Pl. 8, fig. 15; and the Helix creneluta, Pl. 12, fig. 10; brought by Olivier, differ in form from all the other freshwater shells yet known, and, as M. Brongniart justly observes, if found in the fussil tate, would certainly have been considered as marine.

(2) Foss, in Gravel and Alluvial Clay; London Clay; Crag Marl. 


\section{( 35$)$ \\ DIVISION XVII. GONYOSTOMATA}

1. Trochus. (1) Lam.

Conical; mouth more or less quadrangular, in an oblique plane to the axis of the shell; operculum thin, horny, orbicular.

\section{GENERA.}

Base flat or concave.

Marine, or inhabiting the brackish ponts communicating with the sea.

V. Animal, p. 66.

a The columella, in the form of a concave arch, continued with the outer lip. Pl. 9, fig. 7 .

6 Calcar, Montf. Flattened; lip sharp, like the rowel of a spur. PI. 9, fig. 10.

$c$ With a small prominence, or vestige of a tooth, towards the base of the columella.

d Mouth much broader than long; base concave. Pl. 9, fig. 9 .

$c$ Mouth much broader than long; and the columella in the form of a spiral canal.

$f$ Turreted.

$\dot{g}$ No projection to the columella.

f $h$ Flattened; the exterior angle edged.

$i$ Flattened; the lips rounded.

$k$ Columella with a prominence towards the base.

l Columella embattled lengthwise.

2. Cirrites. Sowverby,

Conical; whorls united. Pl. 9, fig. 4.

No columella: umbilicus funnel-shaped.
In the Chalk Marle, under Oolite, and Der. byshire - Peak Limestone:

3. Solarium. (2) Lam.

Spire like a dilated cone. Pl. 9, fig. 11.

A very large umbilicus, hollowing out the base.
Marine.

V. Animal, p. 66.

4. Euomphalites. Sowerby.

Rolled almost in the same plane, depressed bilicate underneath. above. Pl. 9, fig. 18, 19.

5. IANTHiva. Lam.

Subglobulous, horizon- Columella proloñged tally volute; no opercu- beyond the mouth. lum. Pl. 9, fig. 26.

Concave or largely um-

In the LimestoneShale; in the 1 st or Upper Grey and in the Peak Limestone of Derby shire.

V. Animal, p. 67.

Mediterranean. Aus. tralasia.

A floating shell.

(1) Foss in the London Clay; Crag Marl; Under Oolite; Blue Lias ; at Grignon; near Pont Chartrain; Longjumeau. The Trochus agglutinaus, Pl. 9, fig. 8 is remarkable for its habit of agglutinating to, and even of incorporating with, its shell, during the growth, small pebbles, fragments of other shells, sand, etc. etc. rous covers the umbilicus with a testaceous plate. A fossil variety of this cu-

(2) Foss, in the London the seas of South America, is found at Grignon.

(2) Foss. in the London Clay; Purbcek Limestonc; at Grignon. 


\section{DIVISION XVIII. SYPHONOSTOMATA.}

GENERA.

\section{A. With varices. (1)}

\section{Munex. (2) Lam.}

Oval or oblong; turbi- Varices in two opposite nated, canal projecting rows. and straight ; operculum horny.

a Murex, Montf. Canal long and slim; varices spinous. Pl. 10, fig. 3.

$b$ Brontes, Montf. Canal long and slim; varices knotty.

$c$ Typhis, Montf. Canal moderate; varices spinous, with projecting tubes between, penetrating the shell. Pl. 12, fig. 7 .

$d$ Chicoracex, Montf. Canal moderate or long, with folded leaves notched or divided. Pl. 10, fig. 5 .

e Aquila, Montf. Canal moderate or short; varices knotty; umbilicate.

$f$ Lotorium, Montf. Canal moderate or short; varices knotty; not umbilicate.

g Tritonium, Montf. Canal moderate or short; varices simple; spire elevated; mouth generally wrinkled transversely on both lips. Pl. 10, fig. 4 .

h Trophones, Montf. Canal moderate or short; varices numerous, compressed, almost membranous.

i

Canal moderate or short; varices few, very much compressed, projecting considerably.

\section{Ranelia. Lam.}

Turbinated; canal short; Varices bordering both surface armed with tuber sides. cles; lips of the mouth wrinkled. Pl. 10, fig. 6 .
Marine. V. Animal, p. 70.

a. Apollo, Montf. Umbilicate.

B. Without varices.

3. Fusus. (3) Lam.

Fusiform, peristoma en- Columella simple. tire; spire elevated.

Marine. V. Animal, p. 70.

a. Fusus, Montf. Umbilicate.

b. Lathires, Montf. Not umbilicate. Pl. 10, fig. 7.

(1) Varices are projecting callous pads with which the animal edges the mouth or aperture of its shell, each time that it suspends the growth. V.Pl. 10, fig. 2, a.b.c.d.e.

(2) Foss. in the London Clay; Crag Marl; Woolwich Loam; Green Sand; at Grignon, Courtagnon. The Murex tripteris, living in the Indian Seas, near Batavia, is very common at Grignon.

(3) Foss. in the London Clay. In France they are found in the newest Shelly Limestone, and are much more abundant in that than in any other formation. Although the fossil species are numerous, we meet with scarcely any which are perfectly analogous to those now found in the recent state. These remarks also apply to the Fasciolaria, 
4. Fasciolaria, Lam.

Subfusiform. Pl. 10, Columella withoblique Marine. fig. 14.
folds at the base.
V. Animal, p. 70.

a. Fulgur, Montf. Whorls of spire flattened at top ; striated within the mouth.

5. Turbinella, Lam.

Turbinated or subfusiform. Pl. 10, fig. 15.

Columella with large transverse folds.

Marine.

V. Animal, p. 70.

6. Pýrula. (1) lam.

Subpyriform : spire flat- Columella simple. tened or rounded.

Marine.
Generally in warm
climates.
V. Animal, p. 70.

a. Umbilicate. Pl. 10, fig. 8.

$b$. Not umbilicate.

7. Pleurotoma. (2) Lam.

Fusiform; a notch in the right lip towards the spire; canal long : opercu-

Ditto.

Marine.

V. Animal, p. 70.

lum horny. Pl. 10, fig. 13.

8. Glavatula. (3) Lam.

Subturreted; a notch in the right lip towards the spire; left lip excavated; spire pointed. Pl. 13,

Columella toothed.

Marine.

Coasts of Africa.

Animal unknown. fig. 8 .

(1) Foss. at Grignon; Courtagnon; Houdan; Parnes.

(2) Foss. in the London Clay; Green Sand; at Grignon; Betz, near Crepy; Parnes. obscure figure of Seba. 


\section{DIVISION XIX. ENTOMOSTOMATA.}

\section{GENERA.}

\section{A. Turreted.}

\section{Eeurat Lam.}

Shell smooth. Pl. 10, fig. 9 .

2. Anciliaria. (1) Lam. A reILla.

Oblong, spire short. Pl. 10, fig. 10 .

3. Mitrà. (2) Lam.

Turreted or sub-fu- Columella with large siform; spire pointed, folds, the largest nearest mouth oblong. Pl. 10, the spire. fig. 11.

\section{Pyramidella. Lam.}

Mouth broad, crescent shaped. PI. 10, fig. 12.

A callous pad on the

\author{
Columella deeply and \\ broadly umbilicate.
} base of the columella.

Marine.

Marine.

V. Animal, p. 69.
Marine.

Warm climates.

V. Animal, p. 69.

\section{Terebra. (3) Brug.}

Spire at least double the Columella convex or greater diameter of the naked, the visible part mouth : no operculum. very short. Pl. 10, fig 20.

Columella with the base twisted obliquely in sharp, spiral folds.
Marine. V. Animal, p. 63 .

\section{Cerithium. (4) Brug.}

Mouth oval, curved to A gutter in the upper the left at the notch: oper- part of the right lip. culum round and horny.

Marine. V. Animal, p. 70.

a. With varices, but no fold on the columella.

b. With folds on the columella. Pl. 13, fig. 2 .

e. No folds on the columella; no varices. Pl. 1.0, fig. 19.

(1) Fuss. in the London Clay; at Grignon; Courtagnon; Environs of Paris.

(2) Foss. at Grignon; Parnes near Matgny.

(3) Foss. at Grignon; Parnes.

(4) This genus of univalves presents more species in the fossil state than any other. There are already upwards of a hundred in the cabinet of M. De France: they are almost all found in the newest formations. M. de Gerville, however, reports that he has found four species in the bed of Ammonites and Belemnites, in the environs of Baveux.-Journal de Physique, October, 1813. They have been found in England, in the London Clay and in the Chalk Marl. The Cerithium Gigas, pl. 13, fig. 2, is sometimes from fifteen io sixteen inches long, and four in diameter at the last whorl. 


\section{Potamides. (1) Brongn.}

Notch less apparent, right lip dilated. Pl. 10, fig. 18.

No gutter.

Salt-water marshes, or the brackish waters of the mouths of rivers.

Marine.

V. Animal, p. 70.

8. Rostellaria. (2) Lam.

Fusiform ; a second canal, ascending along the spire, formed by the outer lip and by the continuation of the columella. Pl. 10, fig. 16.

B. Oval, sub-coniral, or sub-globulous.

9. Buccinum. (3) Lam.

Oval or elongated ; Columella convex, na" mouth notched below; ked.

Marine.

lips simple : operculum

cartilaginous. Pl. 10, fig.

21.

\section{Dolium. Lam.}

Ventricose; sub-globu- Columella twisted or lous; outer lip undulated, sharp at the base. notched below. Pl. 10, fig. 22.

\section{Harpa. (4) Lam.}

Oval or gibbous; with longitudinal or oblique sharp ribs, the last forming a callous pad at the lip; mouth oblong, simple, notched below。 Pl, 11, fig. 1.

Columella smooth.

Marine.

Generally in warm climates.

Marine.

V. Animal, p. 69.

(1) This Genus is founded on the habits of the animal, rather than on the importance of the character of the shell. Fossil species are found in formations presenting only terrestrial and fresh-water shells. P. Lamarchii, pl 4 , fig. 6, is found in the opaque silex which covers the sand at Lon gjumeau; in the forests of Montmorency; above St. Cloud ; mixed with Lymnxi, Planorbes, and stalks of reeds in the Limestone, east of Aurillac, in Cantal; in the compact limestone beds (with the Helix Cocquii, pl. 4, fig. 20), at Nonette, near Issois, in Puy de Dome. It rcsembles the Cerithium radula, figured by Lister as a fresh-water shell; and, in a lesser degree, the Bulimus auritus of Bruguiere, from the interior of Africa.

(2) Foss. in the London Clay; at Courtagnon; Si. Germain on Laye; Parnes.

(3) Foss. at Grignon.

(4) Although the Harpac are by no means rare in the seas of warm clinates, only two specics have as yet been found in the fossil state, and those in the coarse Shelly Limestone at Grignon and Hautevillc. 
12. NASSA. Lam.

Oval; mouth terminated Columellacovered with below by a deep notch. a plate.

Pl. 10, fig. 23.

13. Purpura. (1) Lam.

Oval. Pl. 11, fig. 2. tened.

Columella naked, flat-

Marine.

V. Animal, p. 69.
Marine.

V. Animal, p. 69 .

a. Purpura.

b. Monoceros, Montf. A spine projecting from the base of the outer lip. Pl. 11, fig. 3.

- Ricinella, Lam. Lip of the columella toothed. PI. 11, fig. 4.

14. Concholepas. (2) lam.

Patelliform; outer lip dentated ; spire very small : operculum oval, horny. Pl. 10, fig. 17.

A furrow from the cavity of the summit terminating between the two anterior teeth of the mouth.

\section{Cassidaria. Lam.} Mon ro: Montfort.

Conical; mouth effusive; notch terminating in a small canal reflected to the left at the base. Pl. 11 , fig. 6 .

16. Cancellaria, (3) Lam.

Oval, last whorl ventricose, right lip furrowed within the mouth; almost entire at the base.

Columella covered by a simple plate formed by the left lip.
Marine. Coast of Peru. Animal unknown. Pl. 11, fig. 6.

Columella with compressed folds and a plate formed by the inner lip.
Marine.

V. Animal, p. 70.
Marine.

V. Animal, p. 69 .

(1) Foss, at Courtagnon.

(2) Lamarck placed the Concholepas with the Patellae, but most zoologists seem now to agree with Bruguiere in approaching it to the Buccinum, since, according to Dombey's report, the animal is furnished with a tendinous operculum, which only partly closes the shell. The muscular impression, like a large horse-shoe open in front, has some resemblance to that of the Calyptrax.

(3) Foss. at Grignon; Picdmont; Environs of Florence. 


\section{(41) \\ DIVISION XX. ANGYOSTOMATA.}

\section{GENERA.}

A. With folds, plaits, or wrinkles, on the columella.

1. Cassis. (1) Brug.

Oval ; mouth oblong or narrow; the notch termi- a plate formed by the left nating in a short canal re- lip, wrinkled transverflected towards the left at sally. the base; right lip wrinkled transversally.

\section{Marine.}

Generally in warm climates, at some distance from the shore, in sandy bottoms.

V. Animal, p. 70.

a. The callous pad of the lip dentated exteriorly towards the notch. Pl.11, fig. 11.

b. The callous pad of the lip not dentated exteriorly towards the notch.

2. Crprea. (2) Lam.

Oval, gibbous in the Mouth long, narrow, Marine. middle, and narrowed at wrinkled transversally V. Animal, p. 68. both ends; lip rolled in- on both sides.

wards : no epidermis. Pl.

11, fig. 7, 9. $a, b, c$.

3. Oliva. (3) Lam.

Sub-cylindrical; notch- Columella striated obcd at the base; mouth nar- liquely.

row; channels between the whorls of the spire. Pl. 11, fig. 13.

\section{Conoelix. Swainson.} Coniform; spire very
short; mouth linear, narrow. Pl. 12, fig. 1.

Columella plaited.

heite.
Marine.

In warm climates. V.Animal, p. 68 .

\section{Voluta. (4) Lam.}

Oval; spire varying in projection, summit obtuse the lowest the largest. or nippled. Pl. 12, fig. 2, $3,4,5$.

$a$ Cymbium, Montf. The last whorl ventricose.

Columella with folds, Marine.

Generally in warn climates.

V. Animal, p. 68.

$b$ Voluta, Montf. The last whorl conical, narrowing at the ends.

(1) The fossil species (and amongst them the Cassis Harpaformis, pl. 11, fig. 12) are found only in the newest formations, and it is remarkable that they are very small, compared with the living ones, which are sometimes of a considerable size. They have been found in England in the London Clay and in the Crag Marl.

(2) In the infant state, the Cyproa resembles a small thin Ancillaria, curved and truncated at the base, pl.11, fig. $9, a$; in the middle age, it is thin, with a project. ing spire, pl.11, fig. 9, $b$; when adult, it is thicker, and the spire is covered, pl.11, fig 9, c. Foss. in the London Clay; at Grignon.

(3) Foss. at Grignon; Aumont, near Montmorency.

(4) Foss. in the London Clay; in the Crag Marl; at Grignon; Courtagnon; Chaumont; Berutuis. 


\section{Makginella. (1) Lam.}

Oblong-oval ; a projecting callous pad on the outer lip ; mouth scarcely notched at the base : no operculum.
Columella with folds.

Spire conical. P1 11, fig. 20.

Spire obscure. Pl. 11, fig. 19. $b$

$a$

c Colombella, Lam. The callous pad of the right lip swelled in the middle; folds of the columella numerous. Pl.11, fig. 17.

7. Volvaria. (2) Lam.

Cylindrical, no appa- Columella with one or rent spire; mouth narrow, several folds at the base. as long as the shell. Pl. 11, fig. 18 .

\section{B. Columella simple.}

S. Struthiolaria. Lam.

Turreted : 3 undulating . Columella covered with sinuses. Pl. 12, fig. 9.

a plate formed by the left lip.
Marine.
Marine.

Seas of warm climates, principally in the neighbourhood of the Senegal.

V. Animal, p. 69.

\section{Strombus. (4) Lam.}

Ventricose, with a short canal; notched or trun- below.

cated at the base; right lip dilated in a wing (in the adult), with a sinus towards the base : operculum horny, long, narrow. Pl. 11, fig. 15.

10. Terebellum. (5) Lam.

Oblong or sub-cylindrical ; mouth narrow above, simple, enlar towards the base, notchcd. Pl. 11, fig. 14.

\author{
Columella truncated \\ below.
}

Dillo.

Marine.

V. Animal, p. 68 .
Marine.
Animal unknown.

(1) Foss. at Grignon.

(2) Foss. at Grignon.

(3) The Museum gave 100 francs for the type of this new genus, which is now figured for the first time.

(4) Foss. in the London Clay; at Grignon.

(5) Foss. at Grignon; Environs of Paris. The Terebellum perditum (the analogous living species is not known! is found in great numbers, and of all ages, at Grignon. 
11. Ptenocera. Lam.

Ventricose, with an elongated canal; right lip dilated in a wing (in the adult) divided into long, narrow digitations. $\mathrm{Pl} .11$, fig. 16.

\section{Conus. (4) Lam.}

Like inverted cones, or cylindrical ; mouth longitudinal, narrow, simple, effusive at the base : operculum small, horny.

\section{Marine.}

V. Animal, p. 70.

a Conical spire, crowned with tubercles. Pl. 11, fig. 21.

6 Conical spire, not crowned with tubercles. Pl. 11, fig. 22.

c Sub-cylindrical spire, not crowned with tubercles.

13. Ovula. Brug.

Gibbous, elongated in Both lips rolled in- V. Animal, p. 68. a point at eachend; mouth wards. longitudinal. Pl. 11, fig. 8,10 .

\section{Aкera. Muller.}

Oval-oblong or oval- Right lip sharp.

Marine.

In the muddy bottoms of the seas of all climates.

V. Animal, p. 61. rolled on itself; no projecting spire; mouth as long or almost as long as the shell, without notch or

Marine.

Generally within the tropics, at ten or twelve fathoms deep, near sandy coasts.

V. Animal, p. 68 . canal.

a Bullaea, Lam. Contained within the mantle, too small to hold the animal. Pl. 5, fig. 18.

$b$ Bulla (5), Lam. Covered with a thin epidermis, large enough to contain the animal, and turned more than the BuLrea. Pl. 5, fig. 17.

C. Almost flat.

15. Aplysia, Lin. LAPLISIA. Lam.

A little convex within, obliquely conical ; base thin, summit thickened

Horny. Marine. V. Animal, p. 60 , and obscurely spiral. Pl. 13, fig, 5 .

(4) Foss. at Courtagnon; Grignon. The Conus deperditus, Lam. found in the calcareous shelly matter in the environs of Paris, is, according to Bruguicre, the analogous fossil of the Cone treillisec, which lives in the Pacific Ucean, in the neighbourhood of Otaheite.

(5) Foss at Grignon. 
16. Dolabella. Lam. Pl.

13 , fig. 6 .

Ditto, but base more enlarged in proportion ; summit more prolonged and curved.

Calcareous.

Marine.

Mediterranean, Indian Seaś.

V. Animal, p. 60 .

17. Pueurobrancius. Cuv.

An oval plate.

Marine.

V. Animal, p. 60 .

18. Planospirtes. (1) Faujas.

Sub-orbicular; a spiral cord-like ridge on the inferior surface. Pl. 1, fig. 20.

(1) This is one of the rarest and most singular shells found at Maestricht, only three having as yet been met with. It seems impossible to determine whether it is an univalve or a bivalve; for although it resembles the valve of an oyster in form and thickness, it wants the little hollow found at the summit of that shell and serving to lodge the ligament which characterises the genus; neither has it any apparent muscular impression. If it be a bivalve, it is nearest to the genus Acardo of Lamark, but its spiral cord or ridge, with the absence of the hollow and muscular impression, lead us to conclude that it is an univalve. 


\section{$(45)$}

\section{GENUS HELIX. (1) FERUSSAC.}

SUB-GENERA.

A. Horizontally volute.

1. Helicogena. Fer.

Globulous or elliptical ; Umbilicus masked. peristoma simple.

a Collumellatæ. Columella solid and twisted. Pl. 7, fig. 7, 8.

6 Acavx. Umbilicus entirely covered by an expansion of the columella. Pl. 7, fig. 11, 14.

c Perforatx. Umbilicus appearing in part, like a cleft, behind the expansion of the columella. PI. 7, fig. 9, 10.

d Imperforatæ. Depressed, umbilicus closed. Pl. 7, fig. 15, 16, 18.

2. Helicodonta. Fer.

More or less globulous Mouth generally toothand depressed; peristoma ed in the perfect state. reflected or thickened.

a Personatx. Peristoma sinuous and thick; or reflected with teeth, plates, or folds.Pl. 7, fig. 17.

6 Lamellatx. Mouth with one or more elongated internal plates. Pl. 7, fig. 19, $a, b, c, d, e$.

$c$ Maxillatæ. Peristoma with large teeth; a gutter at the base of the columella. Pl. 7, fig. 21.

d Anostomæ. Tomogeres, Montf. Mouth reversed or dorsal, with elevated folds or teeth. Pl. 7 , fig. 20 .

e Impressæ. Inner lip with longitudinal elevated folds. Pl. 7, fig. 23.

3. Helicigona. Fer. Ga-

RACOLLA. Lam.

Carinated, sometimes conical.

a Caracolla. Umbilicus covered. Pl. 7, fig. 22; pl. 8, fig. 1, 2.

6 Vortices, Ochon. Umbilicus masked or visible. Pl. 8, fig. 3.

4. Helicella.'Fer. Vor-

TEX. Ocken.

Elliptical or flattened. Umbilicus exposed.

a Lomastomæ. Peristoma reflected.Pl. 8, fig. 8.

6 Aplostomx. Peristoma simple. Pl. 8, fig. 4.

c Marginatx. Peristoma margined. Pl. 8, fig. 5, 7, 18.

(1) Vide p. 30. 
5. Helicostyla. Fer.

Elliptical or trochiform. Columella solid.

a Aplostomx. Columella straight; peristoma simple Pl. 8, fig. 6.

$b$ Lamellatæ. Columella siraight, round; perisloma simple; an internal plate on the last whorl. Pl. 8, fig. 9, 10 .

c Canaliculatx. Columella twisted, as if truncated at the base, or with an internal spiral rib forming a gutter, under the form of a tooth or callosity. Pl. 13, fig. 1.

d Marginata. Columella flattencd, without teeth or plates; peristoma reflected. $\mathrm{Pl} .8$, fig. 11 .

6. Helicophanta. Fer.

Spire depressed ; volu- Perforated or umbili-

tions rapidly increasing cate.

horizontally; mouth very

large and oblique; only

three to three and a half

whorls; the last enormous.

a Vitrinoides. Peristoma simple. Pl. 7, fig. 2.

b Vesiculæ. Peristoma thickened and sub-reflected.PI. 7, fig. 3, 4.

B. Longitudinally volute.

7. Cochlohydra. Fer.

Amphibulima. Lam. Suc-

CINEA. Drap.

Elongated, oval; volu- Peristoma simple. tions rapidly increasing vertically; spire short, with 2 to 4 whorls, the last forming almost the whole of the shell; mouth very large. Pl. 6 , fig. 5 . Pl. 7 , fig. 5,6 .

\section{Cochlostyla. Fer.}

Elongated or ventricose; Columella solid, not spire elevated : whorls in- truncated at the base. creasing rapidly.

a Lomastomx. Peristoma reflected. Pl. 8, fig. 27.

b Aplostomæ. (1) Peristoma simple.

9. Cochlitoma. Fer.

Achat ina. Lam.

Conical or very ventri- Columella solid, flat, cose, solid, little transpa- and truncatedat the base. rent.

a Liguus, Montf. Basc conical; mouth short; outer lip advanced. Pl. 8, fig. 26.

$b$ Achatina, Montf. Ventrical; mouth very large; outer lip vertical. Pl. 13, fig. 3.

(1) The Sultana (Helix Gallina Sultana, Chem.) was sold, at the sale of the Count de Latour d'Auvergne, for 560 francs. 
10. Cochlicopa. Fer.

(Achatina. Lam.)

Oviform or turrcted; Columella solid, flat, thin, transparent; mouth truncated, and arched at narrow. the base.

a Polyphemus, Montf. Oviform; mouth long; outer lip vertical. PI. 8, fig. 22.

b Styloides. Columna, Perry. Turreted; mouth short; outer lip a little advanced. Pl. 8, fig. 19 .

11. Cochlicelra. Fer.

(Bulimus. Brug.)

Conical or turreted; Columella twisted and perforated ; whorls nearly hollow. equal, or the last shorter than all the others together. Pl. 6, fig. 38 .

12. Cochlogena. Fer. (Auricula. Lam. BuhiMus. Lam.)

Oblong or oviform; last Columella hollow, whorl of the spire gene- twisted, straight, perforally longer and larger rated, umbilicate. than all the others together; mouth elongated.

a Umbilicatæ. Columella straight. Pl. 8, fig. 20.

$b\left\{\begin{array}{l}\text { Perforatx. } \\ \text { Bulimulus, Leach. }\end{array}\right\}$ Columella twisted. Pl. 6, fig. 28.

c Lomastomx. Bulimus, Lam. Columella twisted; peristoma reflected, Pl. 6, fig. 27.

d Helicteres. Turbo, Chomn. Mouth short, crescent-shaped. PI. 12, fig. 15.

$e$ Stomotoides. Auricula, Lam. Mouth elongated, angular at its extremities, or effusive in the upper part ; peristuma thickened and reflected; columella large, more or less spiral, sometimes forming a fold in the mouth. Pl. 6, fig. 22, 31.

$f$ Dontostomæ. Mouth crescent-shaped; peristoma margined, a little reflected; columella twisted, hollowed, flattened at the base, or forming a protuberance; often perforated. Pl. 8, fig. 23.

13. Cochlodonta. Fer.

(Pupa. Lam. OdostoMIA. Fleming.)

Cylindrical or fusiform ; whorls equal, numerous, narrow; mouth short, almost as broad as deep in the dircction of the axis: several inner teeth or thin plates; peristoma reflected.

Columella solid or nearly hollow.

"Pupa, Lam. Cylindrical. Pl. 6, fig. 34, 37 ; pl. 8, fig. 32.

6 Chondrus, Cur. Fusiform. I'l. 8, fig. 25 ; pl. 13, fig. 12. 
14. Cochlodina. Fer.

Cinausilia. Drap. Volvulus. Ocken.

Cylindrical or fusiform; whorls equal, numerous, Columella solid, often with plates.

A pedunculated elasnarrow; mouth generally with elevated plates, and always wth one or two gutters.

a Pupoides. Mouth without teeth or plates; peristoma not continuous.

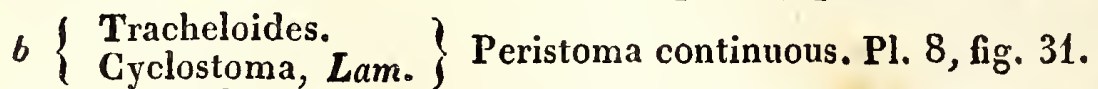

$c\left\{\begin{array}{l}\text { Anomales. } \\ \text { Pupa, Drap. }\end{array}\right\}$ Mouth without plates. Pl. 8, fig. 29.

d Clausilia, Drap. Mouth with plates. Pl. 6, fig. 36.

15. Vertigo. Muller.

Cylindrical, very spi- Peristoma often sinuous ral ; volute increasing and reflected. gradually ; mouth narrow, short in the direction of the axis, often dentated.

a Mouth not dentated. P1. 8, fig. 34.

b Mouth dentated. P1. 8, fig. 35, 36.

16. Partula. Fer.

Oval, pointed ; spire Columellarside callous conical ; last whorl gib- at base.

bous and longer than all the others together; mouth short in the direction of the axis, sometimes dentated or with elevated plates; peristoma generally much reflected. Pl. 8, fig. 30 . 


\section{SHELIS.}

Shells are envelopes, formed by a calcareous subsiance, of a foliated texture, and almost as heavy and hard as marble. They form coverings for a great number of animals of the class of Mollusca; and every one knows that the variety of their forms, their more or less vivid colours, and the brilliancy of their mother of pearl, constitute some of the finest ornaments of the cabinets of virtuosi. We have sufficiently explained these forms, and we shall presently show their relation with the Orders and Genera of the animals which inhabit them: at present we have only to consider their texture, their growth, and the manner in which they are united to the rest of the body.

They are composed, like bones, of a calcareous matter; intimately connected with a gelatinous substance, and which may be, in like manner, separated by means of acids; but this matter is not disposed in lamina, or in fibres; it is uniformly extended throughout the whole body of the shell.

It is only in some species that we find strata easily separated, and, as it were, agglutinated to each other like the leaves of paper in the formation of pasteboard. We know, from observation, that these strata do not all exist in young animals; they have only the most external, which are, at the same time, the smallest. In proportion as the animal increases in age, it forms a new stratum on the internal surface of the shell, which extends beyond the edges of all the preceding strata, so that each operation of this kind adds to the size of the shell, in length, breadth, and thickness. These are certain facts; to prove them it is only necessary to compare some shells of $i^{-1}$ he same species that have belonged to individuals of different ages; the fewest $s^{\text {trata }}$ will always be found in the shells of the young. Muscles, which may is? observed when very young, and even before they quit the matrix of their mother, have, at that period, shells consisting of one stratum only; but the shell is not therefore soft and gelatinous; it possesses the same firmness as the adult shell, and its greater fragility is merely owing to its thinness.

But are the strata which thus successively augment the dimensions of shells, produced by developement, or by a simple juxta-position? Do the nutritive vessels deposit the calcareous juice at different points, or does it only transude through the skin of the animal, and attach itself to the pre-existing strata? These are questions with respect to which physiologists are not agreed.

The body of the snail appears to adhere to its shell only where the muscles are attached; but Reaumur having placed thin pellicles between the body and parts of the shell, which he purposely broke, these fractures were not repaired; but when this, or any other obstacle, no longer prevented the juices flowing from the surface of the skin, the injured part was speedily regenerated.

These facts favour the idea of the simple juxta-position of a transuded matter : we observe, however, on the other hand, that the oyster and muscle adhere to the shell not only by their muscles, but by the whole border of their mantle; besides, the oyster has always between the two last strata of the convex valve, a considerable vacuity, which is filled with a foetid acrid liquor, and which communicates with the interior of the body by a particular aperture. How is this vacuity produced? and, above all, how is it removed upon the formation of each new stratum, if the arterial and absorbent vessels do not penetrate into the centre of the strata, to regulate its position, and to remove, from time to time, the particles of the shell?

Some olservations scem to prove that there are testaceous animals, which, 


\section{(50)}

at certain periods, cast their old shells entirely off, and acquire new ones; but this re-production may also take place by development, as in the horns of the Deer. If the internal strata of those shells which are not cast off, be produced by a developement of this kind, it may be compared to that which forms the internal lamina of the hollow horns of the Ox, Sheep, and other Ruminating Mammalia, and even to that by which the epidermis is produced in all animals; that is to say, there must take place a withering, or, as it were, the death of a membrane, which seems to preserve a sort of organization while it remains unexposed to external elements, or while it has not acquired its proper degree of solidity.

In this manner, it appears, are produced all the hard parts which may be regarded as the bones of animals that have no vertebræ. In cray-fish, for example, the calcareous crust which, in them, is at once skin and skeleton; grows no more after it is completely indurated. The animal, however, continues to increase in all its soft parts; and when these become too much confined by the envelope, the latter splits and is detached: but a new covering is found below the old one, which is formed while the latter loses its connection with the body, and as it were dies. The new envelope is at first soft, sensible, and even provided with vessels : but a quantity of calcareous particles, previously accumulated in the stomach, is soon deposited in this covering, hardens it, obs'iructs the pores and the vessels, and renders it in every respect similar to, the shell it has replaced.

The induration of the covering of insects is not completed until they acquire

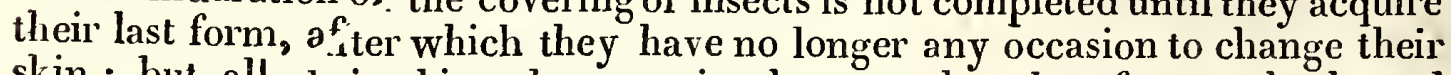
skin : but all their skins they previously cast, though soft, are dead, and already re riaced by others, which develope themselves underneath that which is destir to to fall off.

Al the hard parts, therefore, of white blooded animals, whatever may be "neir consistence and chemical nature, ought to be compared with respect to the manner of their growth to the epidermis, to nails, and to hollow horns, rather than to real bones. The same remark should perhaps be applied to certain external parts of fishes, though their substance is strictly osseous; for instance, to the bucklers of the Sturgeon and Cyclopterus, and the spinous tubercles of the Ray.

Some white blooded animals have also hard parts internally; but they are not articulated in such a manner as to form the bases of moveable members, and their texture differs considerably from that of ordinary bones. The most remarkable of these hard parts are the teeth in the stomach of the lobster.

The common Cuttle-fish (Sepia officinalis) contains in the flesh of the back an oval substance, convex before and behind, white, solid, friable, and of a calcareous nature. This substance is not attached to the flesh, but has the appearance of a foreign body introduced into it. 'There is no indication of any vessel or nerve penetrating it, nor is any tendon affixed to it. It is conposed of thin parallel lamellæ, which are not in immediate contact with each other. 'The intervals are occupied by an infinite number of small hollow columns standing perpendicular between one lamella and another, and arranged in a very regular quincunx.

As the superfices of the lamella are plane, and those of the bone itself convex, they necessarily intersect each other : the points of intersection are marked on the surfaces of the bone by regular cuvilinear stria. These bones have a kind of wings which are of a less opaque nature, less brittle, and have greater resemblance to thin elastic horn, than the body of the bone.

To this last substance the parts called the bone in the Calmar (Sepia loligo) bear a resemblance; they are transparent, elastic, and very brittle; 
their shape is sometimes that of a leaf, and sometimes it is similar to a sword blade. Their connection with the soft parts is the same as the bone of the Cuttle-fish.

We also find a small semi-corneous and semi-friable plate in the body of the fleshy lobe which covers the branchix of the Aplysia, and there is one still smaller in the cloak of the Slug.

Every thing tends to convince us that those hard parts which are found within Mollusca, grow by strata, like their external envelope, and that they are a kind of internal shells.

\section{Mollusca. Cuvier. (1)}

Without vertebræ or articulated members; with blood vessels and nerves (2); a simple spinal marrow; lymph, chyle and blood of the same color (a bluish white); generally with salivary glands; a voluminous liver furnishing a great quantity of bile; no pancreas or mesentery ; muscles (3) attached to the skin, which forms a soft envelope, contractile, engendering (in several species) stony plates or shells; the viscera and nervous system within this envelope, the latter composed of scattered masses united by nervous filaments, the principal of which, placed on the osophagus, are called the brain; a complete system of circulation; respiratory organs ; organs of digestion and secretion almost as complicated as in vertebrated animals (4).

(i) Before Cuvier, naturalists divided all the invertebral animals into two classes, Insects and Worms.

(2) Humboldt has adopted an ingenious method of distinguishing the nerves from the arteries, or other parts, in the smallest animals. He uses two needles, one gold, the other silver : a point of one is applied to the muscles, and a point of the other to the filament, the nature of which he wishes to discover, while the other extremities of these instruments are brought in contact. If the filament be a nerve, contractions immediately take place in the muscular fibre.

(3) The Mollusca with an exterior shell, as Helices, Bulimi, Volutx, etc. have but one muscle which attaches their body to the shell, by a small part of the back and nearly in the middle of its length. This muscle forms a considerable tendon, similar to a thin ribband, which divides itself into two or three principal ribbands. Each of these subdivides itself into several smaller, which disperse and distribute themselves into all parts of the body. The Mollusca with a univalve shell furnished with an operculum, have two muscles of attachment : one of these muscles unites the animal to its shell and resembles that just described in the univalves without opercula; the other, which adheres to the operculum, is generally round, very wide, but not thick.

(4) The Mollusca with a trunk, as the Buccini, Voluta, etc. are carnivorous; they make use of their trunk as a gimblet, and even bore through other shells and suck the flesh of the animals within. Those which have strong horny jaws and a beak like a parrot, are also carnivorous or nourish themselves with animal substances, like the Cephalopoda. The Mollusca which have a muffle and two jaws, one of which at least is furnished with small teeth, are herbivorous or frugivorous, such as the Limaces, Helices, Bulimi, etc. 


\title{
MOLLUSCA.
}

\author{
CLASSES.
}

A. With univalve shells, or none.

\section{Ceprialopoda.}

Body in the form of a bag, open before, containing the branchix.
A head covered with large, long, fleshy productions, serving for locomotion and prehension.

\section{Pteropoda.}

Body entirely closed.
Appendages of the head small or none; organs of movement two wings or membranous fins on the side of the neck, and frequently bearing the branchial tissue.
Sexes separate.

Hermaphrodite.

\section{Gasteropoda.}

Creep on the fleshy disk of the belly, sometimes compressed into a fin (2).
A head distinct and anterior, or none.
Hermaphrodite and sexes separate.

(1) These are the only Mollusca in which organs of hearing have been discovered, and which have the brain (sending forth innumerable optic nerves from the two ganglions) within a cartilaginous box : they are called Cephalopoda because they have the feet on the head. They have three hearts; they respire in water by branchia; their mouth is placed in the centre of their feet, and resembles a beak; the head is also distinguished by very large cyes, and has the ears placed internally; the stomach is muscular like a gizzard, the liver very voluminous. A particular gland secretes a black liquor, which they throw out, and which darkens the water around them whenever they wish to conceal themselves. They swim with their head behind; and walk in all directions with the head below and the body above. Aristotle remarked, that certain herbs, which have a strong odour, were a voided by cuttle-fishes and the octopus.

(2) They are so called because they crawl on their bellies; the head is moveable, and frequently provided with tentacula; the heart is single.

When the name of the genus appears in the following tables without any characteristic particulars, the animal is very imperfectly known. 
B. With bivalve shells, or none.

4. Acephala.

No apparent liead; mouth hidden in the bottom or between the folds of a two-lobed mantle containing the branchiæ which the water passes. and viscera.

\section{Brachiopoda.}

Mantle lobed; mouth Branchix composed exterior, between the ba- of small leaves, ranged ses. of two long fleshy round the edge of the arms supplying the place innerface of each lobe. of a foot and with numerous filaments.

\section{Girrhopoda.}

With numerous hairy filaments, in pairs, composed of small articulations representing feet or fins, towards the orifice of the shell; mouth at the bottom of the shell.
Hermaphrodite.
Fixed, without the power of lecomotion.
Ditto. 


\section{CLASS I. CEPHALOPODA.}

\section{GENERA.}

\section{A. No exterior shell.}

1. Octopus. Lam. (Polypus of the Ancients.)

(1). Pl. 14, fig. 11.

Bag oval, without fins. 8 Feet, very large in 2 Small conical horny proportion to the body, grains on each side of and united by a mem- the back. brane at their base.

2. Loligo. Lam.

Bag with two fins towards the point. Pl. 14, fig. 1, 10!

8 Feet with little suckers (or short pedi-
cles), and two arms to the head, much longer than the feet, with suckers at the end only (2).

3. SEPia. (3) Lam.

A fleshy fin along each Ditto. side of the bag.

B. Shells interior; chambered.

4. Spirula. Lam.

Ditto. Pl. 14, fig. 3.

5. Nautilus.

Ditto.

Mouth with several circles of numerous small.tentacula without

A ligament from the suckers.

A horny plate within the back. 
C. Shells exterior; not chambered.

6. Argonauta. (1)

Ditto.

Two of the tentacula with a membranous enlargement.

(1) The animal uses its shell as a boat, and when the sea is calm it is seen navigating on the surface, employing six of its tentacula as oars, and raising two, which, from the considerable membranous enlargement, serve as sails. Pl. 15, fig. 1 . If the waves are agitated, or any danger appears, the Argonaut draws its tentacula or arms within the shell, concentrates itself, and sinks to the bottom. The ancients were acquainted with this singular animal and its manœuvre; it is their Nautilus and Pompilus.-Plin. IX, cap. 29. Blainville and Dr. Leach consider the animal found in the $A$. argo (Pl. 15, fig. 2) to be parasitical, and allied to the Octopus, under the name of Ocythoë. 


\section{CLASS II. PTEROPODA.}

\section{GENERA.}

A. Head distinct.

1. Guro. Lin.

No mouth ; head formed by two rounded lobes;

Fins with a vasculary net-work instead of tentacula small. P1. 15, branchiæ. fig. 3 .

2. Cleodora. Peron.

Two membranous wing", with the mouth between, having a small lip.

3. Cymbulia Peron.

A large fin with three lobes, two tubercles and a small fleshy beard at the base of the smallest.

\section{Limacina. (1) Cuv.}

Head and wings resembling those of the Clio : body terminated by a spiral tail lodged in a very thin shell.

\section{Paeumodermon. Cus.}

Branchiæ on the surface of the body ; fins small; a small lobe or fleshy tentaculum beneath the mouth. Pl. 15, fig. 4,5 .

\section{B. Head indistinct.}

\section{Hyalea. Lam.}

Two large wings ; mantle cleft at the sides, branchiæ within the clefts. fig. 2 .

No shell. .

Àn envelope. Pl. 5.

Envelope cartilaginous or gelatinous. PI. 5 , fig. 3 .

A shell.

No shell.

A shell.

(1) This animal also uses its shell as a boat, and its wings as oars, when it swims on the surface of the sea. The species known (Clio Helicina of Phipps. Gmel. Argonauta arctica, Fabric Faun. Groenl. 387) is scarcely less abundant in the northern seas than the Clio borealis, and, like it, is said to be one of the principal aliments of the whale. 


\section{(57)}

\section{CLASS IIJ. GASTEROPODA.}

\section{ORDERS.}

1. Nudibranchi. (1) 8,9 .

No shell. Pl. 15, fig. 7 ,

2. Inferobranchi.

Ditto. Pl. 15, fig. 10, $11,12$. mantle.

3. Tectibranchi.

Shell more or less developed, within the mantle. Pl. 16, fig. 1, 2, 3 .

\section{Pulmobranchi.}

A great number with turbinated shells, always without opercula.

Branchiæ covered by the mantle.

\section{Pectinibranchi.}

Shells completely turbinated, and generally more or less closed by the head. Pl.13, fig. 18 . an operculum attached to the posterior part of the foot.

6. Scutibranchi. (2)

Shells very open, often in the form of a shield, without opercula. Pl. 14, fig. 20.

A cavity for respiration, opened and shut at will.

Branchiæ hidden in a dorsal cavity open above

Sexes separate.

\section{Cyclobranchi.}

Shells of one or several pieces, never turbinated, foot, under the edges of without opercula.

Ditto.

Hermaphrodite. sal.

Branchiæ naked, under the edges of the

Branchiæ naked, dor-

(n)




\title{
(58) \\ ORDER I. NUDIBRANCHI. \\ GENER $\Lambda$.
}

1. Donis. (1) Cuv.

Branchia posterior, ranged in a circle.

2 Small conical tentacula to the mouth, and 2 club-shaped from the upper part of the mantle.

\section{Ponycena. Cuv.}

Branchiæe as in Doris, but more simple and with two membranous plates covering them in the moment of danger.

\section{Tritonia. (2) Cuv.}

Branchiæ ranged along the two sides of the back.

2 Club-shaped tentacula before; 4 or 6 others simply pointed.

\section{Thethys, Lin.}

Two rows of branchix the whole length of the back, like bunches of feathers; a large, membranous, fringed veil on the head.

\section{Scyllea. (3) Lin.}

Body compressed ; foot narrow, with a furrow for seizing the stems of Ditto. on the fore part of the mantle.

\author{
Mouth with largc
membranous lips. \\ Mouth with largc
membranous lips.
}

2 Compressed tentacula, with a small coni- trunk without jaws. cal point on the edgc.

Ditto.

Mouth like a sinall trunk.

Mouth a membranous fuci : two pair of membranous crests on the back. Pl. 15, fig. 7, 8, 9 .

\section{Graucus. (4)}

Body long, slim; three or four branchiæ on each 4 Very small conical Swim on their back. side, formed of long thongs, disposed like fans and serving as fins.

(1) A peculiar liquor issues from a gland interlaced with the liver. They are found in all seas. Their spawn is spread like gelatinous bands on stones, varecs, etc.

(2) The orifice for the liquor is pierced to the right, and their mouth is armed within by two lateral jaws, horny and sharp, and resembling shears.

(3) The middle of the stomach is furnished with a leshy ring, armed with sharp horny blades like knives.

(4) They are beautiful little animals inhabiting the Mediterranean and the Ocean, agreeably coloured with azure and mother of pearl, and swim on their back with great swiftness. They have not yet been dissected, and the species are not very clearly distinguished. 


\section{Eolidia.}

Branchiæ like plates or leaves, in transversal rows on the two sides of the back. Pl. 15, fig. 6 .

\section{Tercipes. Cuv.}
A row of branchiæ (1)
2 Tentacula.
Walk on their back. along each side of the back.

\section{ORDER II. INFEROBRANCHI.}

\section{GENERA.}

\section{Phyluidia. (2) Cuv.}

Mantle naked, generally coriaceous. PI. 15 , fig. $10,11,12$.

1 Tentaculum on each side of the mouth, and 2 from above the two small cavities of the mantle.

\section{Diphyluidia.}

Mantle more pointed behind : head semicircular.
1 Pointed tentaculum and a slight tubercle on each side of the head.
Mouth a small trunk.

(1) These are each terminated by a little sucker,-and serve as feet for walking on the back.

(2) Their heart is towards the middle of the back, the stomach is simple and membranous, and the intestine short. 


\section{ORDER III. TECTIBRANCHI.}

\section{GENERA.}

\section{Pleurodranchus. Cuv.}

Body as if between two shields formed by the foot and the mantle ; the latter sometimes containing an oval calcareous plate.

2 Tubulous and cleft tentacula on the mouth (a small trunk), surmounted by a lip.

2 Superior tentacula, hollowed like the ears of a quadruped, with the eyes at the base; 2 others flattened and at the edge of the lower lip.

Ditto.

Body resembling a truncated cone ; shell calcareous.

\section{Notarchus. Cuv.}

Mantle with an oblique cleft above the neck communicating with the branchiæ.
Ditto.
Branchiæ along the left side, in the furrow between the mouth and the foot.
Branchiæ on the back and attached to a stem covered by a small membranous mantle, containing a hollow flat shell.

(1) They have four stomachs; the second is fleshy, sometimes armed with bony pieces, and the third furnished interiorly with longitudinal projecting plates; the intestine is short.

(2) An cnormous membranous crop conducts to a muscular gizzard, armed within by pyramidal, cartilaginous corpuscles, followed by a third stomach sown with sharp crooks, and a fourth in the form of a cœcum : the intestine is roluminous. These animals feed on fucus. A peculiar gland furnishes, by an orifice situatcd near the womb, a limpid humour, which is said to be sour in some species; a dcep purple liquor issues abundantly from the edges of the mantle, with which thc animal colors the water to a considerable distance on the approach of danger. When Apuleius was accused of magic and poisoning, it was reported as a principal evidence that he had engaged some fishermen to procurc him an Aplysia (SeaHare) ; and it is to the following part of his description that we owe the only characteristic which has enabled us to recognise so celebrated an animal. "It has an extraordinary property, of which my predecessors have been ignorant, which is, that being otherwise destitute of bone, it has twelve small ones in its belly, similar to the astragali of the hog, attached and tied together." The form of the Aplysia explains the name of Sca-Harc; and their smell, and the liquor which they produce, account for the pernicious propertics attributed to them. 
5. AKERA. (1) Muller.

Tentacula so short and broad as to appear wanting or replaced by a fleshy rectangular shield. Pl. 16, fig. 1,2, $3,4,5$.

\section{ORDER IV. PULMONACE}

\section{GENERA.}

A. Terrestrial; shell interior; almost all with 4 tentaculd.

1. Lrmax. (2) Lin.

Body elongated ; a Orifice of respiration fleshy disk instead of a on the right side towards mantle, anterior and co- the front. vering the pulmonary cavity only. Pl. 13, fig. 18. Pl. 15, tig. 13.

2. Testacella. (3) Lam.

Mantle very small, pos- Orifice of respiration terior. Pl. 16, fig. 18. posterior.

3. Parmacella. Cuv.

Mantle membranous, Orifice of respiration with the edges flaccid. under the right side of Pl. 14, fig. 9. Pl. 16, fig. the middle part of the 9. mantle.

B. Terrestrial; shell exterior; almost all with 4 tentaculd. 4. Vitrina. Drap. HEulco-Limax. Ferus. (4)

Body protected in front by a sort of cuirass, and behind by a thin shell Body too large to enter entirely within the which may be partly covered by the lobes of the collar or mantle. Pl. 14, fig. 12.

(1) Their hermaphroditism, the position of their two sexes, the complication and armour of their stomach, the purple liquor produced by several of their spe-
cies, approach them to the Aplysia.

( 2 ) Their mouth has only an upper jaw, in the form of a dentated crescent,

(3) The $T$. haliotide gnaw herbs and fruits.

de Ferussac has observed, that its mantle, and feeds principally on worms. M. too dry a place, affording it a sort of shelter. (4) The mantle has a double edge ; the upper, which is divided into several
lobes, can extend far beyond the shell, and fold back to rub and polish it. lobes, can extend far beyond the shell, and fold back to rub and polish it. 


\section{Helicarion, Ferus.}

Body truncated behind, with a cuirass in front, under the anterior edge of which it retires its head : shell posterior ; foot separated from the body by a furrow and with a mucous pore at its extremity. Pl. 14, fig. 7. Pl. 16, fig. 6.

\section{Helix. (1) Lin.}

Body with a muscular disk or foot, sometimes pediculated, more or less gibbous and spiral above.
a. Bulimus, Lam. (2)
b. Pupa, Lam.
c. Scarabxus, Montf.
d. Chondrus, Cuv.
e. Amphibulima, Lam.
f. Clausilia, Drap. (4)
g. Achatina, Lam. (5)

Mantle forming a kind of ring or collar (at the point of junction of the two parts of the body), in which is pierced the round orifice of the respiratory cavity.
Head indistinct, with two pair of retractile tentacula, the posterior the larger, and bearing the eyes at the summit; mouth with a pair of short appendages.

(1) V. p. 74.

(2) Large and beautiful species are found in warm countries : some are remarkable for the size of their eggs, the shell of which is stony ; and others for their sinistral shell. The Helix decollata has the singular habit of breaking the whorls at the top of its spire, proving that the muscles of the animal can detach themselves from the shell without injury, and that they adhere to different points of the shell successively. How is it that they thus effect the separation of the vessels from one part to implant them in another? for it sometimes happens that this Helix or Bulimus has but one of the original whorls of its spire left. Some species of Pupa, Clausilia, and Mclania are found in the same state. The Kambeul of Adanson appears to pass the dry season in a deep trance, like the Limax of Europe, for he found several half buried after the month of September. Some had even already began to close the mouth of their shell with a whitish plastery matter, to defend themselves from the long drought, which continues at Senegal from October to the following June.

(3) This animal may perhaps be considered as a Testacella with a large shell. Its inferior tentacula are very small, and it lives on herbs and bushes by the side of streams, which has caused it to be thought an amphibious genus.

(4) In the narrow part of the last whorl we generally find a small plate, slightly curved like an $\mathrm{S}$ : its use to the animal is unknown.

(5) At the extremity of the truncated columella we find the first indication of the notches in the shells of the marine Gasteropoda. 
C. Aquatic; 2 tentacula.

\section{Without a shell.}

5. Onchidium. (1) Buchanan.

A broad fleshy mantle. Pl. 16, fig. 8.

2 Long retractile tentacula, and two triangular lips.
Orifice of respiration under the posterior part of the mantle.

With shells.

6. Axcruus. Geoff.

Eyes at the inner base of the tentacula.

7. Planonbis. (2) Brug.

Pl. 16, fig. 10.

Tentacula thin, fili- Ditto. form.

7. Lymáus. (3) Lam.

Tentacula compress- Eyes near the base of ed, broad, triangular. the inner edge.

8. Physa. (4) Drap.

Two dentated lobes to the mantle.

Tentacula thin, pointed.

Eyes at the inner base, which is much enlarged.

9. Auricula. Lam.

10. Conovula. Lam.

11. Tornatella. Lam.

12. Pyramidella. Lam.
Animals unknown, but (from the form of the shell and the absence of the operculum) approximating to the Auricuta.

(1) The ${ }^{\text {se }}$ mollusca, destitute of jaws, have a muscular gizzard, followed by two menibranous stomachs.

(2) $\Lambda$ red and abundant liquor exudes from the edges of its mantle, but it is not their blood; they are the constant companions of the Lymnxi in all stagnant waters.

(3) We find them floating on the surface of the water with the foot turned upwards, and very rarely crceping on hard substances; when disturbed they fall or sink, and remain a long time immoveable before they reappear at the surface.

(4) This animal, when it swims or creeps, covers its shell with the two dentated lobes of its mantle. 


\section{ORDER V. PECTINIBRANCHI.}

\section{FAMILIES.}

\section{Trochö̈da.}

Shell spiral, mouth entire, without notch or canal. Pl. 9, fig. 7 .

2. BuccrNö̈DA.

Shell spiral, with a notch or canal for the passage of the siphon, which is a prolonged fold of the mantle. Pl.10, fig. 21.

3. Sigaretoïda.

Shell flattened, hidden during life within a spongy buckler which is the true mantle. Pl. 5, fig. 25. Pl. 14, fig. 15, 16.

\section{An operculum.}




\section{FAMILY 1. TROCHOIDDA.}

\section{GENERA.}

1. Turbo. Lin.

Shell tuibinated, mouth round.

\footnotetext{
(a. Turbo, Lam. (1) Membranous wings on the side of the foot. Pl. 17, fig. 6, 7, 8, 9,

2 Long tentacula.

Eycs on stems at the outer bases of the tentacula.

2 Triangular, flattened, Ditto. small tentacula.

d. Turritella, Lam.

e. Scalaria, Lam. (2) Pl. 17, fig. 1.

2 Long, slim tentacula. Ditto.

(1) To these belong the thick, strong opercula, so frequently found in collections، which were formerly employed in medicine under the name of unguis odoratus.

(2) The mouth is encircled by a callous pad, which the animal repeats from space to space as its shell increases, so as to give the appearance of ladders.
} 


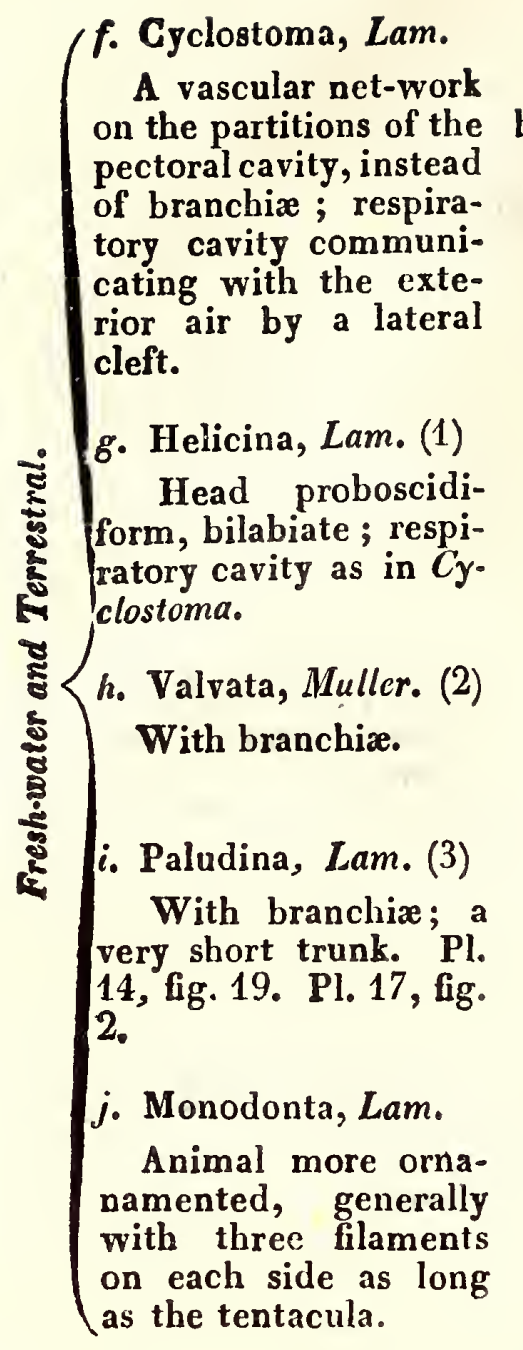

2 Tentacula terminated by blunt tubercles.

2 Filiform tentacula.

2 Slim tentacula.

2 Pointed tentacula.
Eyes on two tubercles near the base of the tentacula.

Eyes at the outer base. base

Eyes at the superior

Eyes at the outer base.

\section{Trochus. Lin.}

Mouth of the shell angular, more or less quadrangular, oblique to the ax is.

a. Trochus.

Three filaments at each edge of the mantle, or appendages to the foot. PI. 17, fig. 3 , $4,12^{*}, 13$.

b. Solarium.

(1) M. Blainville is convinced that this is the place of the Helicina; but M. de Ferussac says that it has a collar, with the respiratory hole pierced to the left.

(2) In the $\boldsymbol{V}$. cristata the branchix, formed like a feather, proceed from underneath the mantle, and float beyond it with a vibratory motion when the animal wishes to breathe; on the right side of the body is a filament resembling a third tentaculum.

(3) The female of the $\boldsymbol{P}$. vivipara produces living young, which are found in her oviductus, in the spring, in all the stages of developement. Spallanzani asserts that these young separated at the moment of their birth, and nourished apart, reproduce without fecundation like those of the Vine-fretter. The $P$. cristata one of the small species found in salt water ponds, and described by $M$. Beudant, moves its tentacula incessantly as oars when it sails on the surface of the water. 
3. Conchylium. Cuv.

Entirely aquatic or breathing by branchiæ.

a. Ampullaria.

Animal not yet described, but probably resembling the Paludina.

\section{Animal not well known.}

c. Phasianella.

Double lips notched and fringed, each wing with three filaments.

2 Long tentacula.

Eyes on two tubercles at the outer base of the tentacula.

d. Ianthina. (1)

A vesicular organ un. der the foot, like a frothy ball but solid, which admits of floating but not of creeping; head like a cylindrical trunk, month with little fangs. Pl. 14, fig. 13.

4. Nerita. Lin.

Shells with the columella straight, the mouth semi-circular or semi-elliptic, and closed entirely. by an operculum.

\section{a. Natica, Lam.}

Foot large; operculum horny. PI. 17, fig. $17,18$.

Tentacula simple.

b. Nerita, Lam. (2)

- Foot moderate ; nperculum stony. Pl. 17, fig. 11, 12 .

\section{c. Neritina.}

Foot moderate; oper. culum horny.

(1) The common species (Helix Ianthina, Lin.) List. 572,24 , is a pretty violet-
coloured shell, abounding in the Mediterranean coloured shell, abounding in the Mediterranean. When the animal is touched,
it sheds a thick liquor of a deep violet colour, which tints the sea amoud it

(2) The opercula of some univalre ated by ginglymus.

Eyes at the base of the tentacula.

Eyes on stems at the side of the tentacula. 


\section{PAMII.Y IT. BUCCINOÏDA.}

\section{GENERA.}

\section{Conus, Lin.}

Trunk elongaling considerably ; operculum placed obliquely on the foot, narrow, too short to close the mouth of the shell; a long respiratory tube. Pl. 16 , fig. 12.

\section{Crpred. (1) Lin.}

Mantle large enough to curl up and cntclope the shell: foot thin; no operculum. Pl. 16 , fig. 11 .

3. Ovue. Brug.

\section{Tereetium. Lam.}

5. Voluta. Lin.

Shell terminaled by a notch, with projecling and obligue folds on the colnmella. Pl. 18, fig. 1,2.

a. Oliva, Brug.

A tube above the lead for respiration.

\section{b. Voluta.}

An elongated trunk, cylindrical and retractile, with small crooked teeth; a respiratory tube projecting obliquely behind the head; foot very large ; no operculum. $\mathrm{Pl} .18$, fig. 2.

\section{c. Gymbium.}

A very large foot; no operculum. $\mathrm{Pl} .18$, nig. 1.
Tentacula elongating considerably.

Tentacula moderate.
Eyes near the points on the outer side of the tentacula.

Eyes at the outer base.

2 Long pointed tentacula.

2 Pointed tentacula, from a veil on the head.
Eyes towards the mid. dile of the tentacula.

Eyes at the onter base.

(1) The mantle is sufficiently large to turn back upon the shell and envelope it; at a certain age it covers the shell with a layer of another colour, so that this differ. ence, ndded to the form assumed by the aperture, might cause the adult to be tahen for another species. V.p. 41 . 
d. Marginella.

Foot very large, part. ly covers the shell by raising the lobes of the mantle; a retractile trunk, a respiratory tube above the head; no operculum.

e. Mitra.

\section{f. Cancellaria.}

\section{Buccinum.}

Shells without folds on the columella; with a notch or short canal in flected towards the left, for the passage of the respiratory tube. Pl. 10, fig. 21.

\section{a. Buccinum.}

No veil to the head; a trunk; a respiratory tube formed by the mantle; operculum horny. Pl. 17, fig, 15, 16. Pi. 13 , fig. 16, 19 , 20.

b. Eburna, Lam.

c. Dolium, Lam.

d. Harpa, Lami.

c. Nassa, Lam.

Ventral disk enlarged, truncated anteriorly, prolonged beyond the head; a tube above the head formed by the mantle.

\section{f. Purpura, Brug. (1)}

Foot elliptical; respiratory tube prolong. cd above the head; operculum cartilaginous. Pl. 17 , fig. 14.
2 Conical tentacula far apart.

2 Pointed tentacula.
Eyes on the outer base of the tentacula.
Eyes on the outer side of the tentacula.

\section{Ditto.}

Eyes in the middle of the outer part of the tentacula.

(1) The animal furnishes a matter fit for dying red, which the ancients used, and which is still cmployed in the north of Europe. 
g. Cassis. Brug.

Animal resembling the Buccinum, but the operculum horny and dentated in order to pass between the wrin: kles of the outer lip. Pl. 18, fig. 7 .

h. Cassidaria, Lam.

Animal resembling the Buccinum.

i. Terebra, Lam.

7. Cerithium.

Shell with a turreted spire, mouth oval, canal shoit, curved to the left

A veil on the liead.

No veil.

Canal of the shell projecting, straight ; operculum horny. Pl. 10, fig. 2.

a. Murex, Lam.

A retractile trunk; a tubulous prolongation of the mantle; operculum small, horny.

Pl. 18, fig. 4, 6. Pl. 19, fig. 2 .

b. Ranella, Lam.

c. Fusus, Lam. Pl. 18, fig. 5.

d. Turbinella, Lam.

e. Pleurotoma, Lam.

f. Pyrula, Lam.

g. Fasciolaria, Lam.

9. Strombus. Lin.

Canal straight or inflected towards the right; lip dilating with age but preserving a sinus near the canal, under which the animal passes its head.

a. Strombus, Lam.

Operculum horny, long, narrow; foot small. Pl. 19, fig. 1 .
b. Pterocera, Lam.
c. Rostellaria, Lam.

2 Long tentacula, near to each other, with the eyes at the exterior side.
Two tentacula, far the side. 


\section{FAMILY III. SIGARETOÏDA.}

\section{GENERA.}

1. Sigaretus. Cuv.

A notch and semi-canal in front, conducting the water into the branchial cavity. Pl. 14, fig. 15, 16.

Tentacula conical.

Eyes at outer base of the tentacula.

\section{Cinptostoma. Blainv.}

Foot enormous, four or five times larger than the body ; mouth hidden under the anterior edge of the shell.

Tentacula short, conical, with appendages at the base.

\section{ORDER VI. SCUTIBRANCHI.}

GENERA.

1. Halyous. Lin.

Shell turbinated. Pl. 5. fig. 24 .

\section{a. Halyotis. Lam. (1)}

Mouth a short trunk. Tentacula lon some Eyes on two cylindrical Pl. 13, fig. 21. Pl. 14, fig. 20. Pl. 19, fig. 3, 4,5 .

at the cdges of the cavity stems.

of the branchia, and passing through the last holes

b. Padolla. of the shell.

c. Stomatia. (2)

2. Capulus. Montf.

Shell conical; branchiæe on the anterior edge of the cavity; trunk rather long; a folded membra-

2 Gonical tentacula.

Eyes on the outer base of the tentacula. nous veil under the neck. Pl. 16, fig. 7.

(1) The mantle is deeply cleft on the right side, and the water which passe through the holes of the shell, proceeds by this cleft into the branchial cavity. There are three or four filaments along the edges of the mantle, which the animal has the power of pushing out through the holes.

(2) The animal is ool known: it may possibly belong to the Pectinibranchi. 


\section{Crepidula. Lam.}

Shell with an oval base; the abdominal bag) containing the viscera) on the plate of the shell; the foot beneath; the head and branchiæ in front. Pl. 16, fig. 15, 16, 17.

Shells, and the position of the heart and branchice, symmetrical.

4. Fissurella. Lam.

A conical shell on the middle of the back, with a small hole at the summit (for the passage of the water for respiration) extending to the cavity of the branchix on the fore part of the back; a branchial comb on each side; with filaments on the sides of the foot. Pl. 16, fig. 44. Pl. 19, fig. $6,7$.

5. Emarginula. Lam.

A fissure instead of a hole, for the same purpose; edges of the mantle covering a great part of the shell. PI. 16, fig. 13.

\section{Sertaria. Fer. Navi- CELIA. Lam.}

A moveable, angular, testaceous plate (besides the shell) hidden in the back of the abdominal bag.

7. Garinaria. (1) Lam.

A compressed, muscular portion under the belly, serving as a fin; shell attached on the branchix ; a trunk; head furnished with tubercles. Pl. 14, fig. 17.

\section{Calyptrael lam.}

2 Conical tentacula.

Eycs at the outer base of the tentacula.
Eyes on a tubercle at the outer base of the tentacula.

\section{Tentacula.}

liyes at the base of the tentacula.

(1) The skin of these animals is almost gelatinous, and has a layer of fibres under it, which, when they are taken, contracts so much as to tear tho body and let out the intestines. 


\section{ORDER VII. CYCLOBR $A$ NCHI.}

\section{GENERA.}

1. Patella. (1) Lin. Shell of a single piece ; a cord of small branchial

2 Pointed tentacula. Eyes at the outer
base of the tentacula. leaves under the edges of the mantle; a thick, short trunk. Pl. 14, fig. 5, 6.

2. Chiton. (2) Lin.

A range of testaceous, A membranous veil symmetrical scales along on the mouth instead of the back of the mantle. tentacula.

(1) The mouth is fleshy, and contains a spiny tongue, lengthened posteriorly, and folded deeply within.

(2) The shell of the Chiton will be figured and described with the Multivalves. 


\section{HELIX.}

The eggs of the Helices are generally round, white, and moderately large ; they are at first rather glutinous, and especially in those species which deposit them in series or in the form of a chaplet. They are frequently deposited one by one, or in an irregular mass, in looles hollowed in soft ground by the animal; but generally in natural excavations, cracks in the ground, trees, rocks, or old walls, where there is a constant humidity. At the end of a period, which varies according to the species, and perhaps according to circumstances, the eggs hatch, and a small snail comes out, clothed with a shell (Pl. 7, fig. 3) so extremely thin and so nearly membranous, that, fearful of the effect of the air and sun, they only quit the holes wherein they were born, during the night. They at first grow very rapidly, and afterwards so gradually that the growth may be judged of by the striæ of the shell : they probably live very long, but this is a part of their history not very well known. The increase of their bodies necessarily requires a proportionate increase of the shell, and at the period when this takes place, the Helices assemble in numbers: the animal remains in a state of repose, buries itself in some cavity, and there produces from every part of its mantle, and especially from the edge (thickened into a pad), a layer of a glutinous, calcareous matter, which lies within the preceding, projecting a little beyond its edge ; it is this point of junction with the new layer which forms the stria marking its growth, and it is as much wider as the animal is better nourished and more vigorous. When the shell has attained its full growth, it merely thickens, and in the greater number of species forms a callous pad, more or less thick; it also deposes, on the part of the spire which invades the mouth of the shell, a thin calcareous matter, which joins the two lips, and is called a callosity. (Pl. 7, fig. 3.) Although this is termed the complete or finished shell, the animal becomes adult, or has the power of reproduction, long before: but it is important to remark, that the shell of the same individual differs considerably according to the age of the animal. The spire is less elevated as the animal is younger, and the last whorl is consequently much greater in proportion; the umbilicus is more exposed, the mouth wider, the lip sharper, and the shell thinner. When it is completed, the last whorl swerves from the spiral line which renders the mouth narrower. We also find anomalies which we cannot account for. (V. Pl. 7, fig. 12, 13,14. Pl. 6, fig. 13.)

It appears that the larger species serve as food in several countries. According to Pliny, the Romans consumed a great many, and sought them for their tables, and he gives the name of the person who first thought of raising them in a sort of park and fattening thein with choice food. L. 8, c. 39.

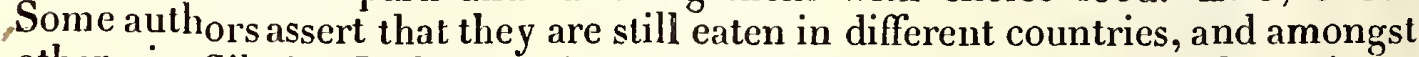
others in Si'esia, Brabant, liége, Switzerland, Italy, and several provinces in France. In the neighbourhood of Rochelle they are said to be parked by putting them one alove another in layers, moss or other plants being strewed between each. It is admitted that those which live in elevated spots are the best, and that they partake a little of the taste of the plants on which they feed. The Ashantees eat snails after they have been smoke-dried, and the Tamoul people eat the animal of the Ampullaria (Pl. 9, fig. 1), which they call Netté. A great many are sold in the markets of Paris and other great cities, not as food, but to make mucilaginous broths for those who are attacked with certain disorders of the lungs. One would be still more inclined to dorbt the efficacy of snails in curing hernia in its earliest stage, by producing the contraction of the inguinal ring; yet M. Georges Ta- 
renne, the author of a little treatise called Cochlioperie, assures us of this. He employs the blood of the animal, which he obtains by pricking it with a sharp-pointed instrument, and puts it in the shape of a cataplasm on the cushion of the bandage.

Physiologists have made use of these animals to prove that reproduction does not confine itself to unimportant parts, or to animals of a very low rank. The beautiful experiments of Trembley, on green hydre or fresh water polypi, had put it beyond doubt, that in this degree of organisation an animal could not only reproduce the different parts of its body, but that, if it were cut in pieces, each piece would become a perfect animal : he even caused six and seven heads to spring from a simple body, by dividing the animal into as many longitudinal shreds. The following year (in 1745), Bonnet, wishing to repeat the experiments of Trembley, and being unable to procure the green hydræ, tried if fresh water worms, a spccies of Naïs, could not also reproduce the parts which were cut off. He cut the body into 26 parts, and each part reproduced a complete animal. This faculty of reproduction when mutilated, was also demonstrated in the Actinice, by the Abbé Dicquemare; who shewed that their bodies might be divided into a considerable number of parts, if a part of the mouth were left on each shred. . In 1764 Boscovisch announced, in a letter to Lacondamine, that snails, when their heads were cut off, could reproduce others entirely similar, as the experiments of the Abbé Spallanzani had proved. Some experiments on the same subject, even more conclusive than those of Lavoisier, Schoeffer, Bonnet, Muller, etc. were made by M. G. Tarenne, who published them in 1808. They proved that snails can reproduce their entire head, since he assures us that the piece which he cut suddenly with 'very sharp scissars, placing them perpendicularly a little behind the great tentacula and under the foot, contained not only the tentacula, the jaw, and the upper lip, but the brain and anterior part of the foot. The snails thus mutilated reproduced a complete head at the end of a year or more; and if other observers, adds M. Tarenne, have not witnessed this fact, it is because they have not enabled the mutilated. Helix to nourish itself. Spallanzani, however, does not speak of this circumstance, and positively says that the head is regenerated whether the section is made above or below the brain. The new head only differs from the old by having a whiter and smoother skin; sometimes there is a sort of furrow at its junction with the trunk. According to Spallanzani, it would seem that the manner in which this reproduction is made is variable, and that sometimes it remains incomplete; but M. Tarenne says, that having cut off the heads of 200 Helices, and thrown them into a damp grove at the end of a garden, (that they might find their proper nourishment the more easily,) at the end of the fine weather he perceived a new head, resembling a grain of coffee, on all the individuals which he could again meet with : this head had four small horns, a mouth, and lips. At the cnd of the following summer the heads were perfectly reproduced, with the difference only of the skin being smooth or cicatrised. Although Spallanzani has given fewer details than M. Tarenne, it is clear that he had alleady oblained the same results. Still it is difficuit to conceive how the nervous filaments, the muscles, the vessels which have been cut in the m ddle of their length, reaccord with the portions which shoot forth from the head, which has become a sort of bud; or, admitting that the regeneration proceeds from the nervo:s and musculary filaments themselves, how the former can shoot forth and give birth to the brain. For entire conviction, it is neccssary to have a careful dissection made of the head thus reproduced, and to compare it with that which has been cut off. 


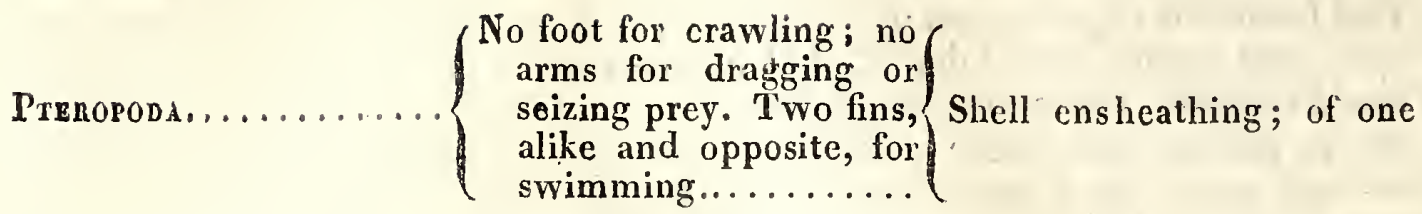

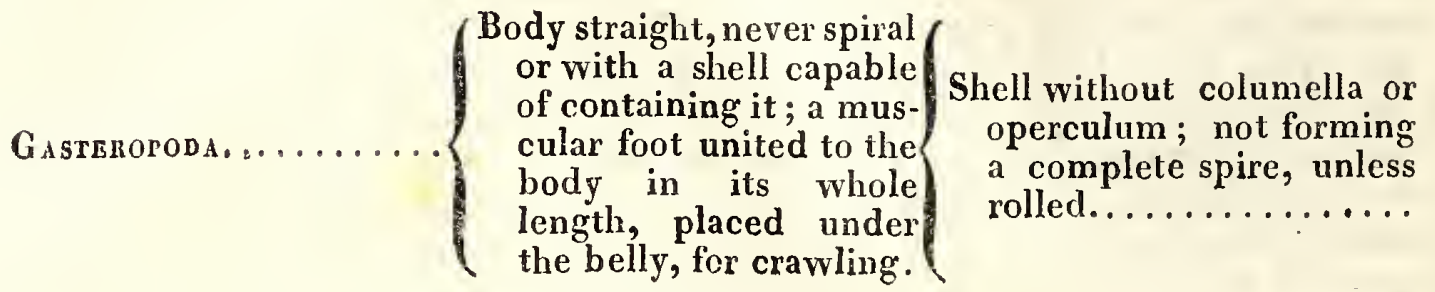

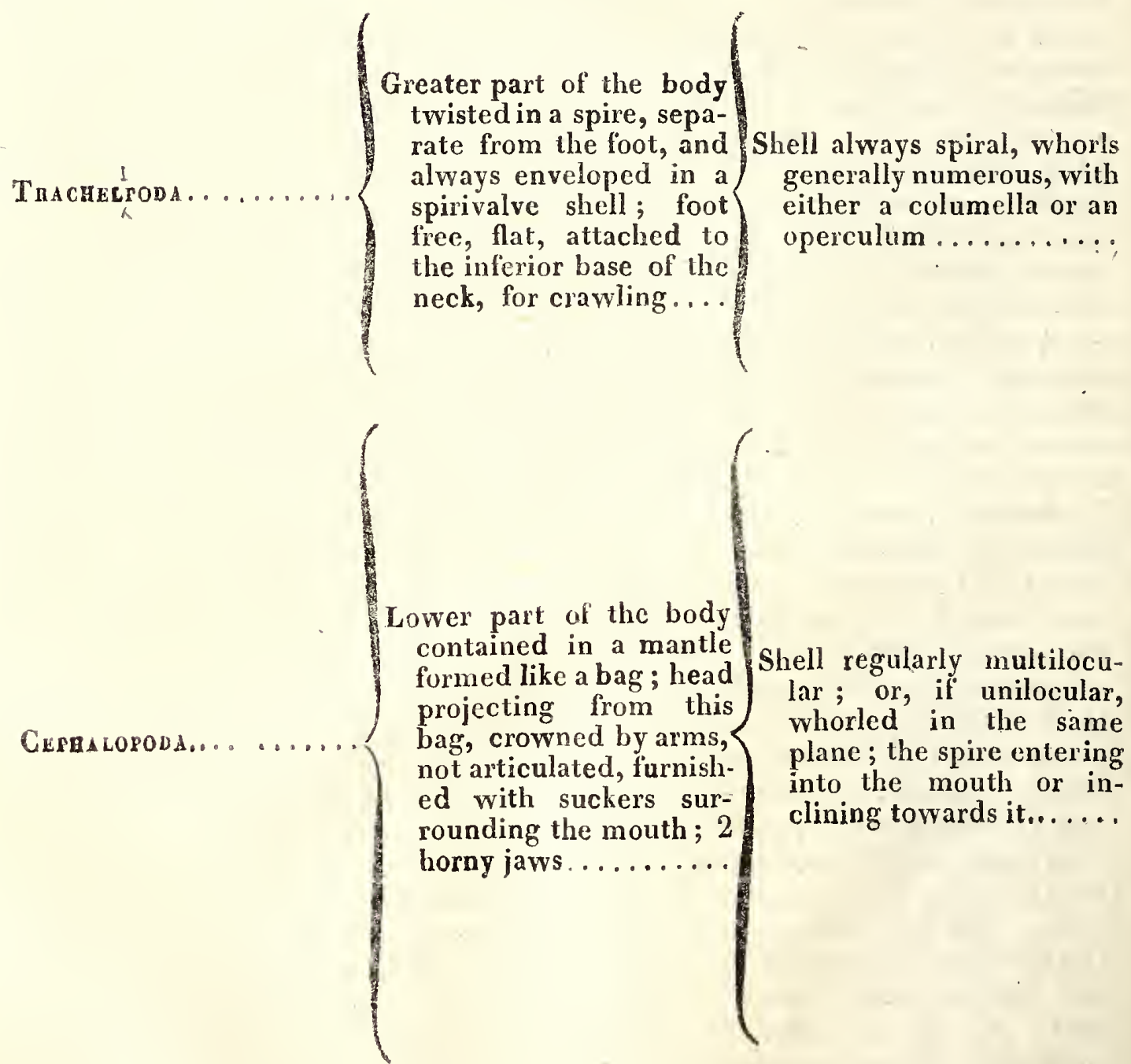




\section{OF LAMARGK'S SYSTEM.}

piece, never spiral, always exterior..................... 1 .

Shell exterior, covering: in one piece in the form of a shield, cap, or sandal; or in several imbricated pieces: imperfectly or not at all 2 .

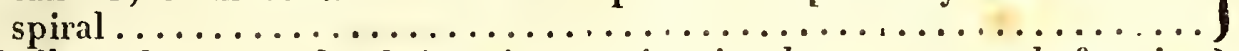

Shell partly or completely interior; cavity simple or none; only forming 3 . a spire when the whorls completely cover each other............

Shell exterior; not capable of entirely containing the animal; the spire 4

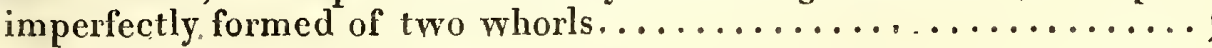

\section{4.} outer lip not changing with age ..............

A channel more or less long at the base of the shell; ? outer lip changing its form with age and having a

Shell channelled

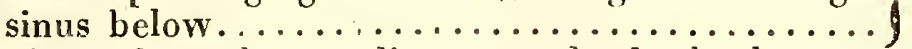

6. Ganalifare.

7. Acate.

or notehed, or

A short channel ascending towards the back, or an oblique notch sub-ascending at the base of the shell.

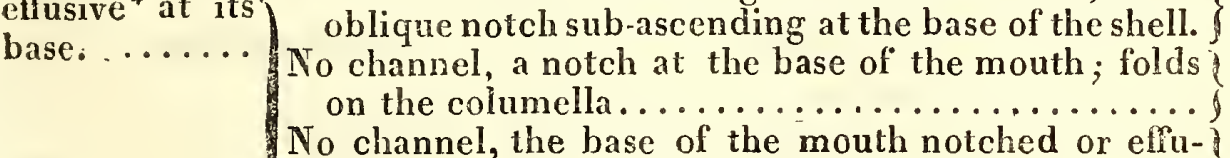

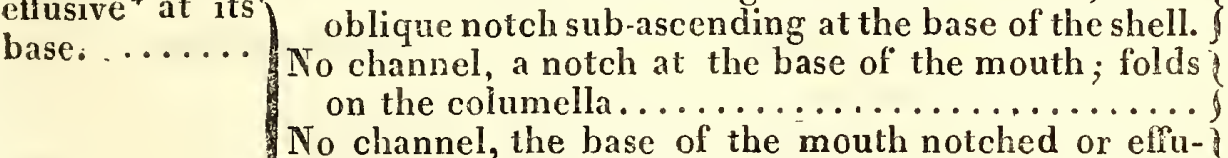

No channel, the base of the mouth notched or effu-
sive; the whorls large, rolled round the axis...... Invoness.

8. Purpuriteras.

9. Colvmelrate.

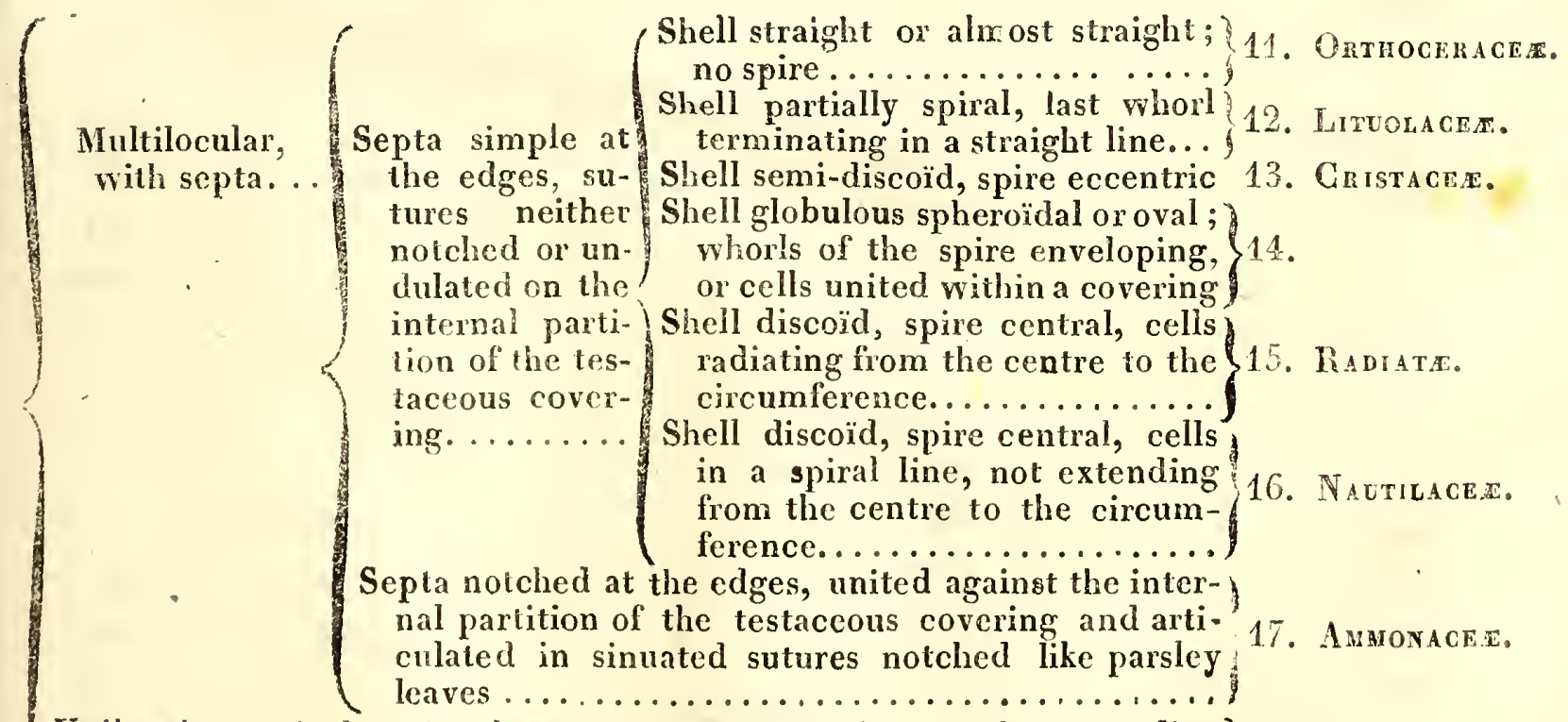

Unilocular, univalve, involute; spire entering the mouth or tending

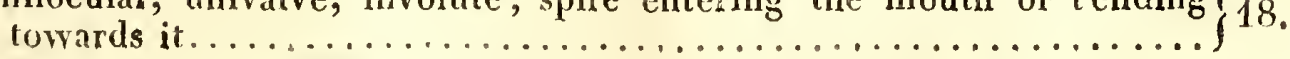

- $y$. Note, p. 27. 



\section{OF LAMARCK'S SYSTEM.}

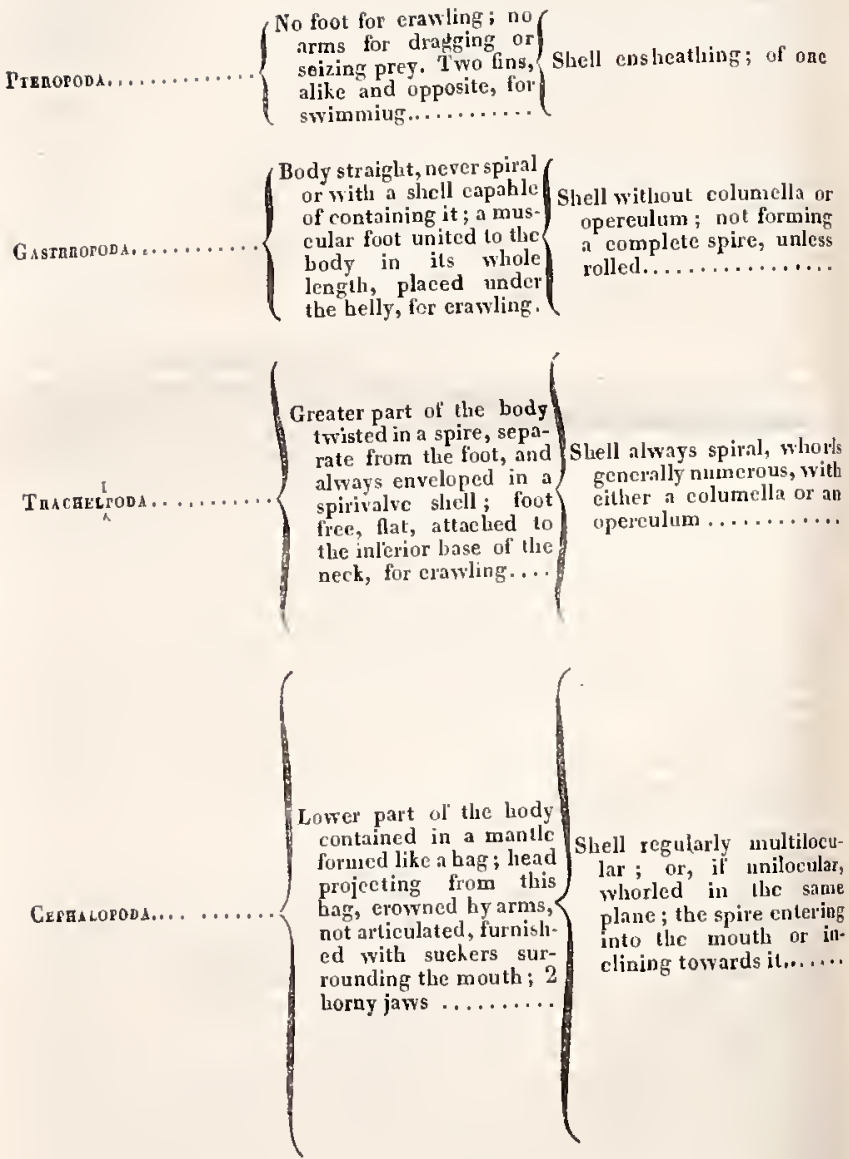

piece, never spiral, always exterior..................... 1

Shell exterior, covering: in one piece in the form of a shield, enp, or sandal; or in sereral imhricated pieces : imperfectly or not at all $\} 2$. Shell partly or completely interior; cavity sinple or nonc; only forming 3 .

a spire when the whorls completely eover each other............. Shell exterior; not eapable of entirely containing the animal; the spire 4

imperfectly formed of two whorls........................

Montin of the shell entire; no notch or canal at the base ............. 5 .

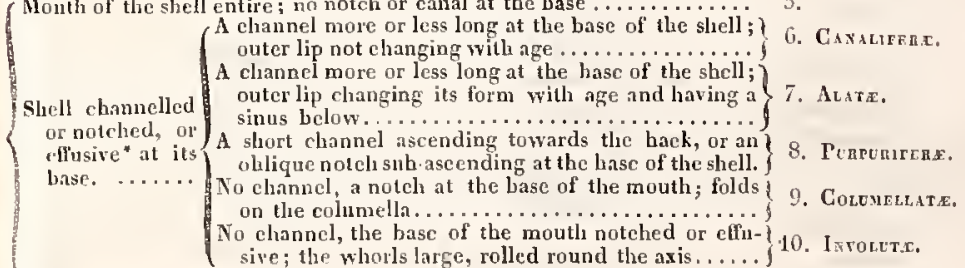

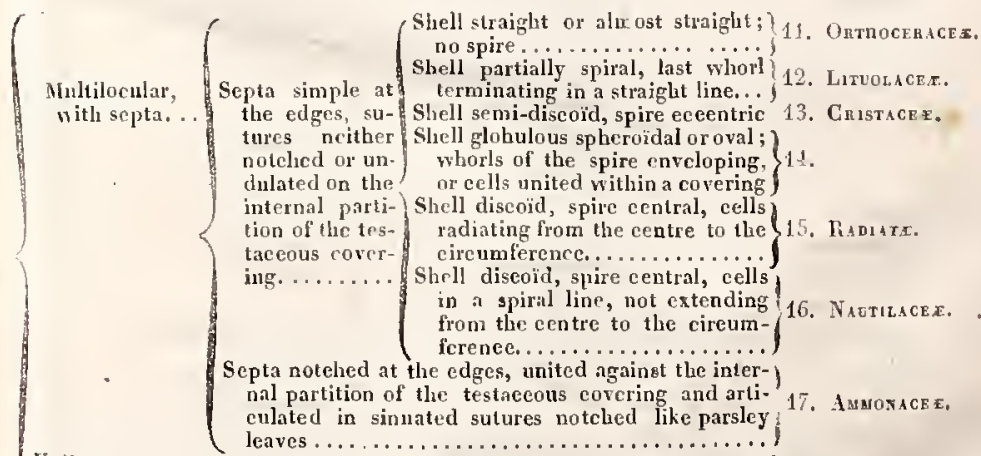

Unilocalar, mivalve, involute; spire cntering the mouth or tending ? 18 .

\footnotetext{
* $r$. Nole, p. 27.
} 


\section{LAMARCK'S DIVISIONS.}

1.

Hyalea .......... 23

Cleodora......... 23

Cymbrulia....... 23

2.

Ghiton.......... 24

Patella.......... 24

Ancylus......... 25

Umbrella ........ 24

Scutina.......... 24

Fissurella........ 24

Emarginula ...... 25

Calyptrxa........ 25

Crepidula ....... 25

3.

Dolabella ........ 25

Bullæa.......... 43

Bulla.......... 43

4.

Testacella....... 26

Vitrina ........ 26

5.

Helix............ . 30

Carocolla ......... 31

Anostoma........ 31

IIelicella.......... 45

Helicina........ 31

Pupa.......... 30

Clausilia... ...... 29

Bulimus......... 29

Amphibulima ..... 29

Achatina......... 28

Cyclostoma ....... 34
Page.

Auricula. . . . . . . . . 28

Lymnæus........ 27

Physa.......... 27

Planorbis....... $\quad 30$

Melania ......... 27

Melanopsis........ 27

Pyrene .......... 28

Conovula ........ 28

Paludina......... 34

Valvata.......... 34

Ampullaria........ 31

Navicella ......... 24

Neritina ......... 32

Nerita........ . . 32

Natica....... . . 32

Ampullina . . ... 31

Ianthina......... 35

Tornatella ....... 29

Pyramidella....... 38

Vermicularia ...... 33

Scalaria......... 33

Delphinula....... 33

Halyotis ......... 26

Stomatia......... 26

Stomatella....... 26

Sigaretus ....... 26

Turritella........ 33

Phasianella....... 28

Turbo......... 33

Monodonta....... 34

Trochus ........ 35

Solarium......... 35

\section{Cuntalifere.}

Cerithium....... 38

Pleurotoma ....... 37
Page.

Clavatula ........ 37

Turbinella ....... 37

Fasciolaria........ 37

Pyrula.......... 37

Fusus........... 36

Murex.......... 36

Ranella.......... 36

Triton......... 36

Struthiolaria ....... 42

7. Aratas.

Rostellaria....... 39

Pterocera........ 43

Strombus......... 42

8. Purpurifene.

Purpura ......... 40

Concholepas....... 40

Harpa ......... . 39

Dolium.......... 39

Buccinum........ 39

Terebra ....... . 38

Cassidaria ....... 40

Cassis........... 41

Nassa .......... 40

Ricinula......... 40

Monoceros....... 40

Eburna......... 38

\section{Columellata.}

Cancellaria....... 40

Colombella ....... 42

Mitra.......... 38

Voluta.......... 41

Marginella ....... 42

Volvaria ......... 42 
I.AMARGK'S DIVISIONS.

Page. Page.

10. Invouter. Spirolinites...... 21

- 21 16. Nauthagex.

Ovula.......... 43 Lituolites......., 20 Discorbites....... 15

Cyprea......... 41 13. Caistacbe. Siderolites....... 15

Terebellum ....... $42 \quad$ Nummulites ...... 15

Ancillaria........ 38 Renulites....... 15 Nautilites........ 22

Oliva............ 41 Cristellaria........ 21

Conus.......... 43 Melonites........ 16

17. AMMONAGER.

Ammonites...... 22

11. Onthoceracee.

14.

Orbulites........ 22

Belemnites....... 17

Orthoceratites..... 17

Nodosaria......... 17

Miliolites........ 16

Gyrogonites....,... 16

Turrilites ........ 18

Ammonoceratites... 21

Baculites........ 18

Hippurites....... 18

12. Lituolacbe.

15. Radiate.

18.

Rotalites.......... 22 Argonauta ....... 23

Spirula......... 21 Lenticulinites ..... 22 



\section{N D E X.}

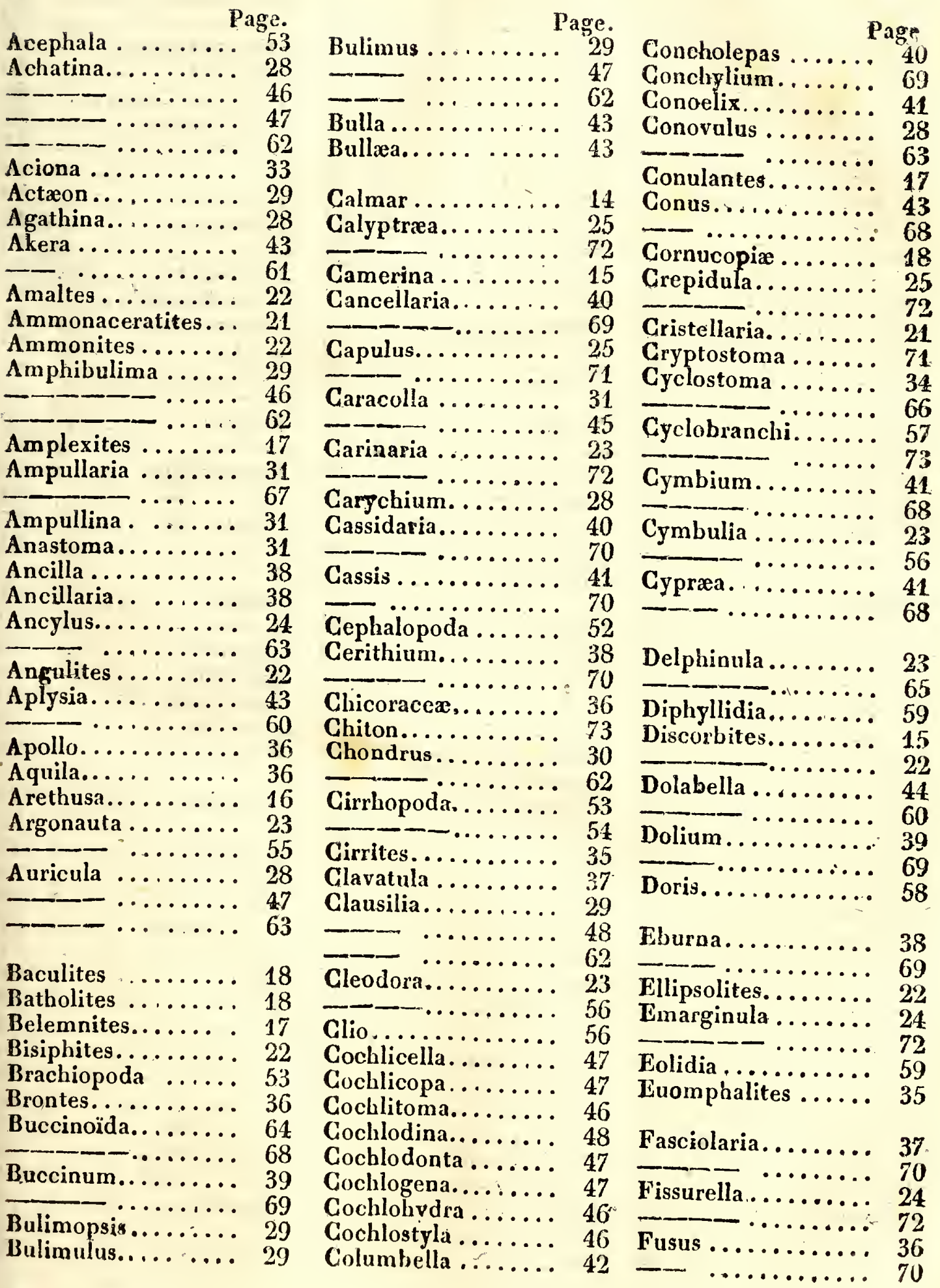




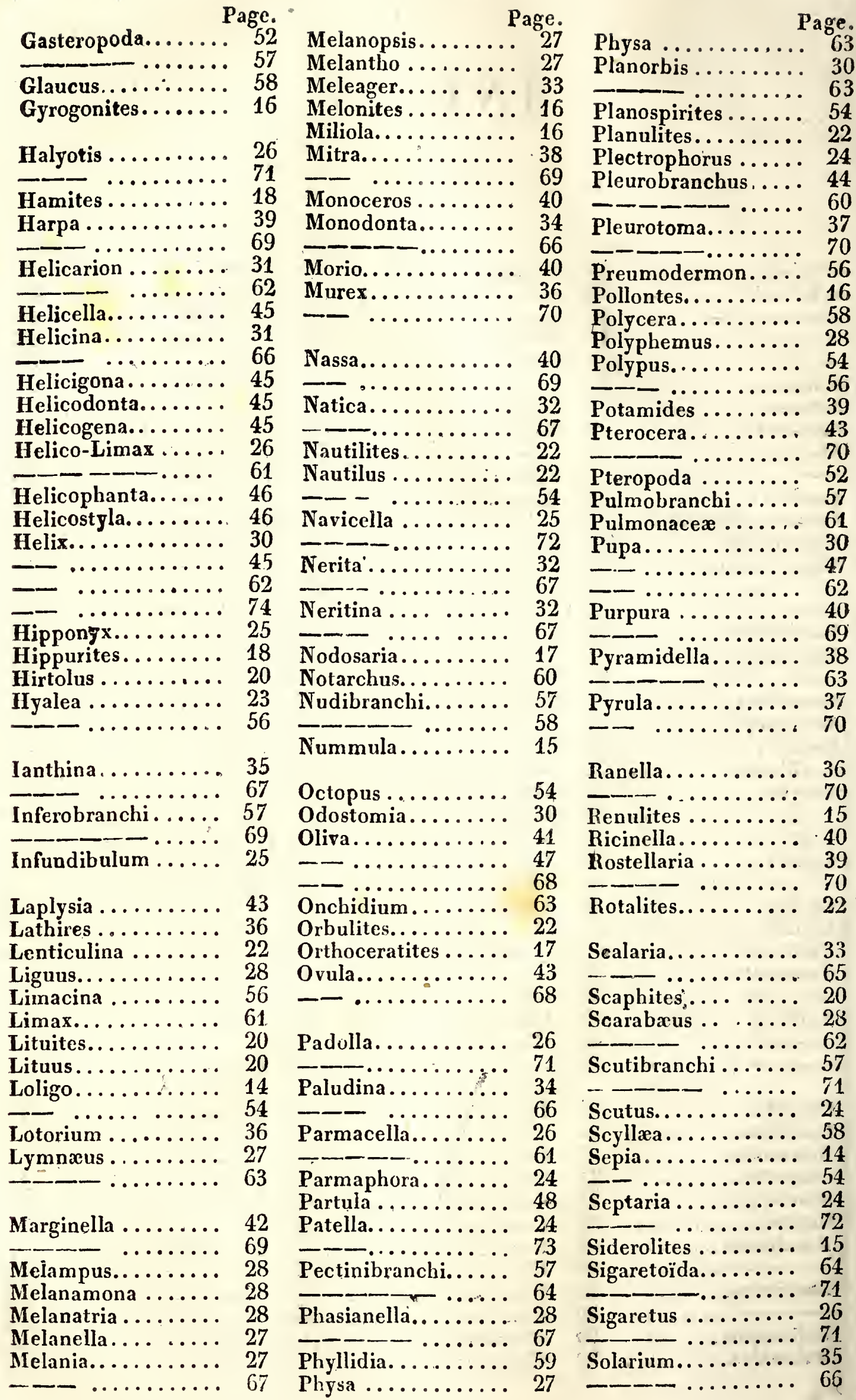


I N D E X.

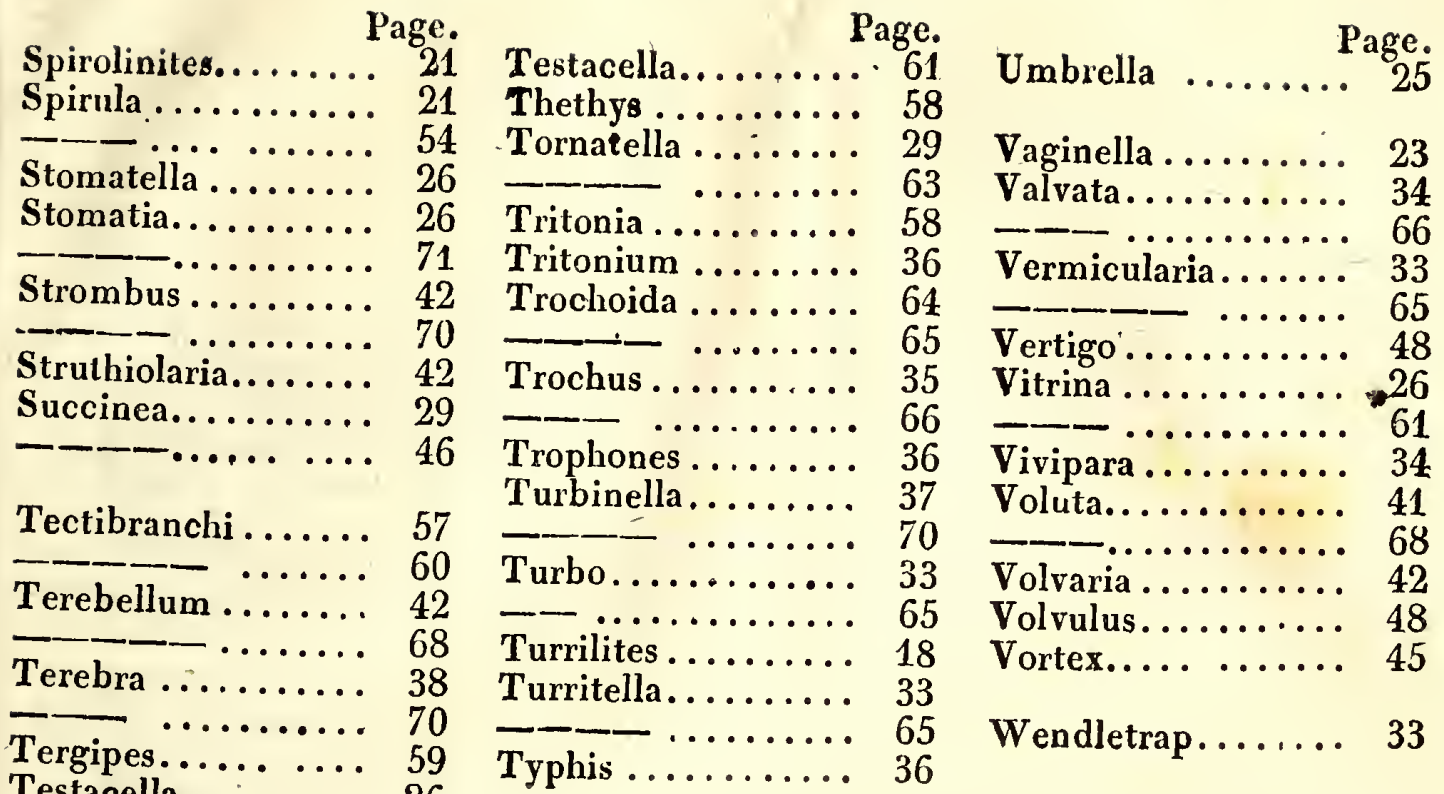





\section{BY THE AUTHOR.}

An ANALYSIS of the NATURAL CLASSIFICATIONS of MAMMALIA, including the Systems of Cuvier and Illiger, and illustrated by upwards of 200 figures (comprehending the Extinct or Fossil Genera and Species), principally from the objets themselves in the Gallery and Cabinet of Comparative Anatomy of the Jardin des Plantes, Price 15s.

An INTRODUCTION to the ORNITHOLOGY of CUVIER, illustrated by 261. figures (including several anatomical), principally from the objects themselves, and drawn off on tint. Price $15 \mathrm{~s}$.

These two works have been adopted as text books by Professor Jamieson of the Edinburgh University.

An ESSAY on the SUPERSTITIONS, CUSTOMS, and ARTS common to the Ancient EGYPTIANS, ABYSSINIANS and ASHANTEES : with coloured figures of part of the objects of manufacture presented by the Author to the British Museum. 4to. Price 8s.

It is presumed that this little Essay will prove, by a variety of curious Evidence, that Abyssinia is not the only part of Africa which has been partly civilised by an intercourse with colonists and emigrants from ancient Egypt, and that much light may be reflected on Antiquity as well as Natural History and Physical Science, by pursuing the British Discoveries in the interior of Africa, gradually and in detail,

An ENQUIRY into the BRITISH and FRENCH EXPEDITIONS to TEEMBO, with remarks on Civilisation in Africa. Price 2s.

An ESSAY on the GEOGRAPHY of NORTH WESTERN AFRICA, with a 2-sheet lithographic map, constructed by the Author from original Itineraries, and detailing the Arabic Itinerary from Ashantee to Mecca, which was mislaid at the time of the publication of the Mission to Ashantee. Price 10s. $6 \mathrm{~d}$.

" M. Bowdich a donné à part une carte speciale du pays des Aschantis, basée " sur ses propres observations, sur des itinéraires détaillés et sur la comparaison " qu'il en a faite avec les cartes de d'Anville et les relations des autres voyageurs. "Cette partie de son travail, ainsi que ce qu’il a donné sur les environs de Gaboon, $"$ " sont des acquisitions précieuses pour la géographie. Le reste de la carte de

" M. Bowdich est beaucoup plus hypothètique, et se fonde sur des documents plus " incertains. - Malgré tant de causes d'imperfection, la carte de M. Bowdich " sera utile, parce qu'a beaucoup de sagacité l'auteur a joint une profonde ètude " de son sujet, et qu'elle offre des recherches, des rapprochements curieux, et des "conjectures probables, présentés d'une manière claire et méthodique. Tout ce " que M. Bowdich ècrira sur l'intérieure de l'Afrique, sera toujours un objet: "6 d'attention pour tout homme instruit."-Walckenaer (Président de l'Académie des Inscrip. et des Belles Lettres) Recherches sur l'Afrique, p. 326, 330, 344.

The CONTRADICTIONS in PARK'S LAST JOURNAL EXPLAINED, and his, Astronomical Observations in 1796 re-established, by the corrections necessitated by bis having reckoned on the 31 st of April.

The ELEMENTS of ALGEBRA, with Historical and Explanatory Notes, and a Supplementary Volume containing calculations and notes for the aid of Students: (who are out of the reach of a Tutor) in reading Le Gendre's Trigonometry, Biot's Analytical Geometry, La Croix's Calcul Differentiel et Integral, and Pois-
son's Mechanics.

During a residence of two year's and a half at Paris, with the vicw of perfecting 
himself in Mathematics and Pbysical Science, as necessary for the greater scientific results of a second travel in Africa, the Author has had occasion to read the greater number of the French works on the elementary parts of mathematics, and to compare them with our own. He was astonished to find that England, which has produced Harriot, Wallis, Barrow, and Newton who may be considered as the father of analysis; that England, possessing at the present moment so many illustrious men of science, does not afford elementary books enabling students to read the works of Euler, Lagrange, Laplace, Legendre, Poisson, and the later English publications, without being arrested by difficulties every moment.

He is aware that the illustrious Professors of Mathematics at our Universities, supply that in their lectures which is wanting in their books ; but he recollects also, from experience, that there are a great number of students throughout the three kingdoms, and especially in our colonies, who are denied the enviable advantages of attending University lectures.

In the hope of remedying this inconvenience in some degree, that is as far as his limited means permit, the Author is induced to publish a course of Algebra, assembling and connecting the materials scattered through the works of La Groix, Bourdon, Boisbertrand, Garnier, etc. etc.

He is not so presumptuous as to believe that this Essay is the best the subject admits of, but he will feel grateful for every candid critic, sufficiently recompensed if it leads to the production of a better work on the same subject; his sole object being to offer something useful to his countrymen. 





\section{PI.ATE I.}

1. Shell of the Sepia rugosa.

2. Shell of the Calmar. Loligo sagittata, Lam.

3. 4. Nummulites, with sections.

5. Discorbite.

6. Miliolite coeur de Serpent.

7. Lituolite.

8. Transverse and longitudinal sections of a Belemnite.

9. 10. 11. 12. Belemnites.

13. Spirolinites.

14. Upper and under view, with a section, of the Gyrogonites medicaginula.

15. Simplegades colubrinus.

16. Turrilites compressus.

17. Baculites vertebralis.

18. a. Spirula fragilis seu australis.

$b$. The siphon traversing the chambers.

c. Section magnified. 
19. Baculites gigas.

20. Planospirites ostracinus.

21. Hippurites cornu-copia.

22. Belemnite.

23. Siderolites calcitrapoides.

24. Section of a Belemnite.

25. Orthoceratite.

26. Hippurite with a gutter, $c$.

27. Hippurite with a siphon.

28. Under view of the operculum of a Hippurite, shewing the two prolongations resembling a hinge.

29. Belemnite.

30. Section of an Orthoceratite with a siphon passing through the axis.

31. Hippurite with a gutter, $a$. and a siphon, $b$.

32. Lituites Breynii, found in the marble of OEland : the shaft or straight part extends in a length equal to the depth of the Plate, gradually enlarging towards the base.

33. Hippurite, the operculum pierced with two eyes.

34. 35. Orthoceratites with a siphon towards the edge or periphery. 




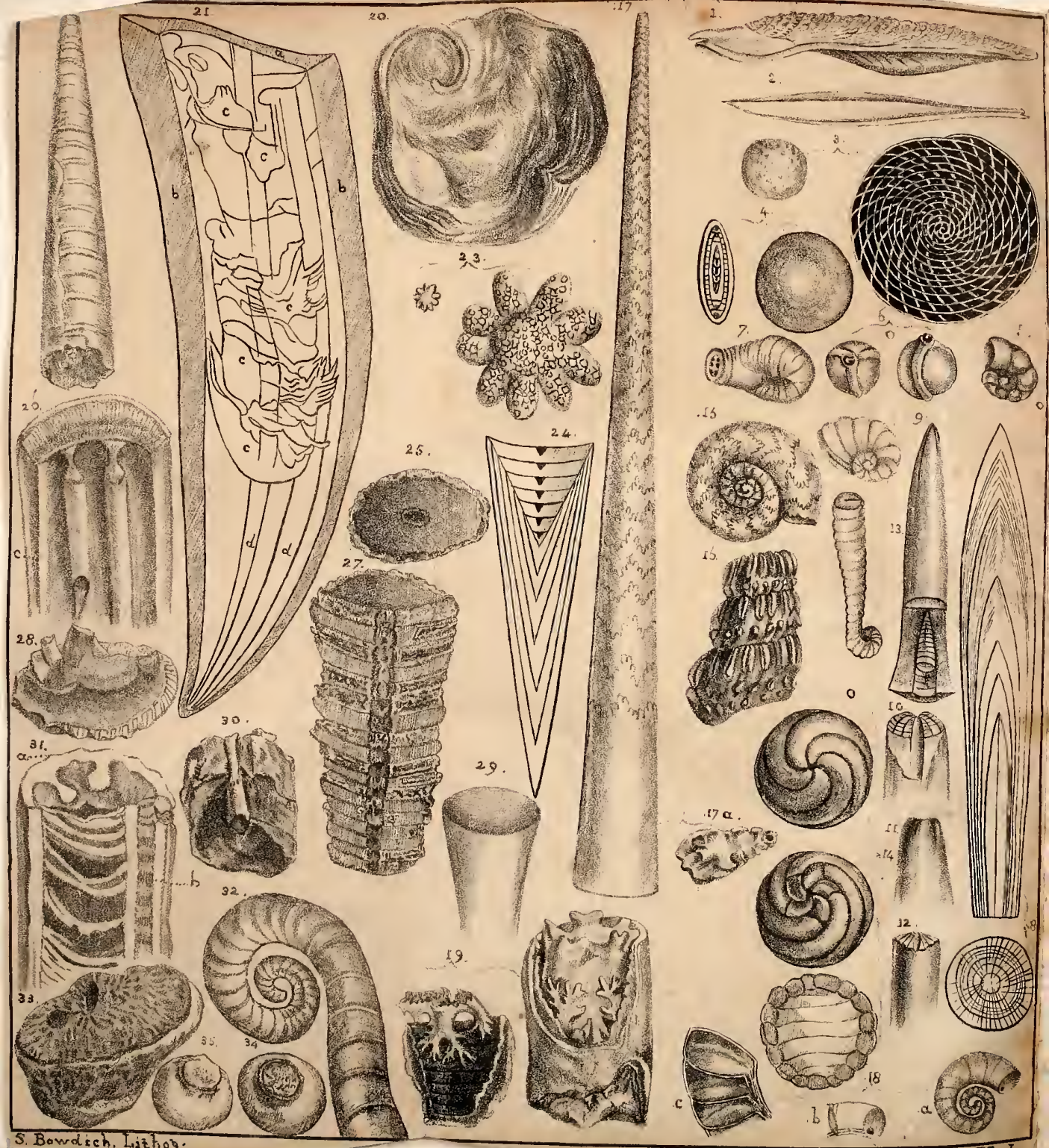




\section{PLATE II.}

1. a. b. c. d. Nautilus melo, with sections.

2. Section of Nautilus flammatus, shewing the siphon.

3. Section of Nautilus caudatus, Lister (N. major seu crassus, Rumph.) shewing the siphon passing through the chambers. 1-4th.

4. Nautilus Pompilius.

5. Nautilus auricula.

6. Scaphites Defrancii.

6. a. b. c. d. Scaphites aqualis.

7. 8. Transverse and logitudinal sections of the spine of the Echinus cidaris. 
9. Nodosaria (Nautilus raphanus).

10. Amplexus coralloüdes.

11. Orthoceratites Gothlandice, 1-2.

12. Molossus gracilis.

13. Rotalite.

14. Echidnis diluvianus.

15. Raphanister campanulatum.

16. Hamites gibbosus.

17. Lenticulite.

18. Hippurites organicus. 

11. Orthoceratites Gothlandie, 1-2.

12. Molossus gracitis.

1. a. b. c. d. Nautilus melo, with sections.

13. Fotalite.

2. Section of Nautilus flammatus, sherring the siphon.

14. Echidnis diluvianus.

15. Raphianister campanulutum.

16. Hamites giblosus.

17. Lenticulite.

sheriing the siphon passing through the chambers. 1-4th.

15. Hippurites organicus.

5. Nautilus auricula.

6. Scaphites Defrancii.

6. a. b. c. d. Scaphites aqualis.

7. 8. Transrerse and logitudinal sections of the spine of the Echinus cidaris.

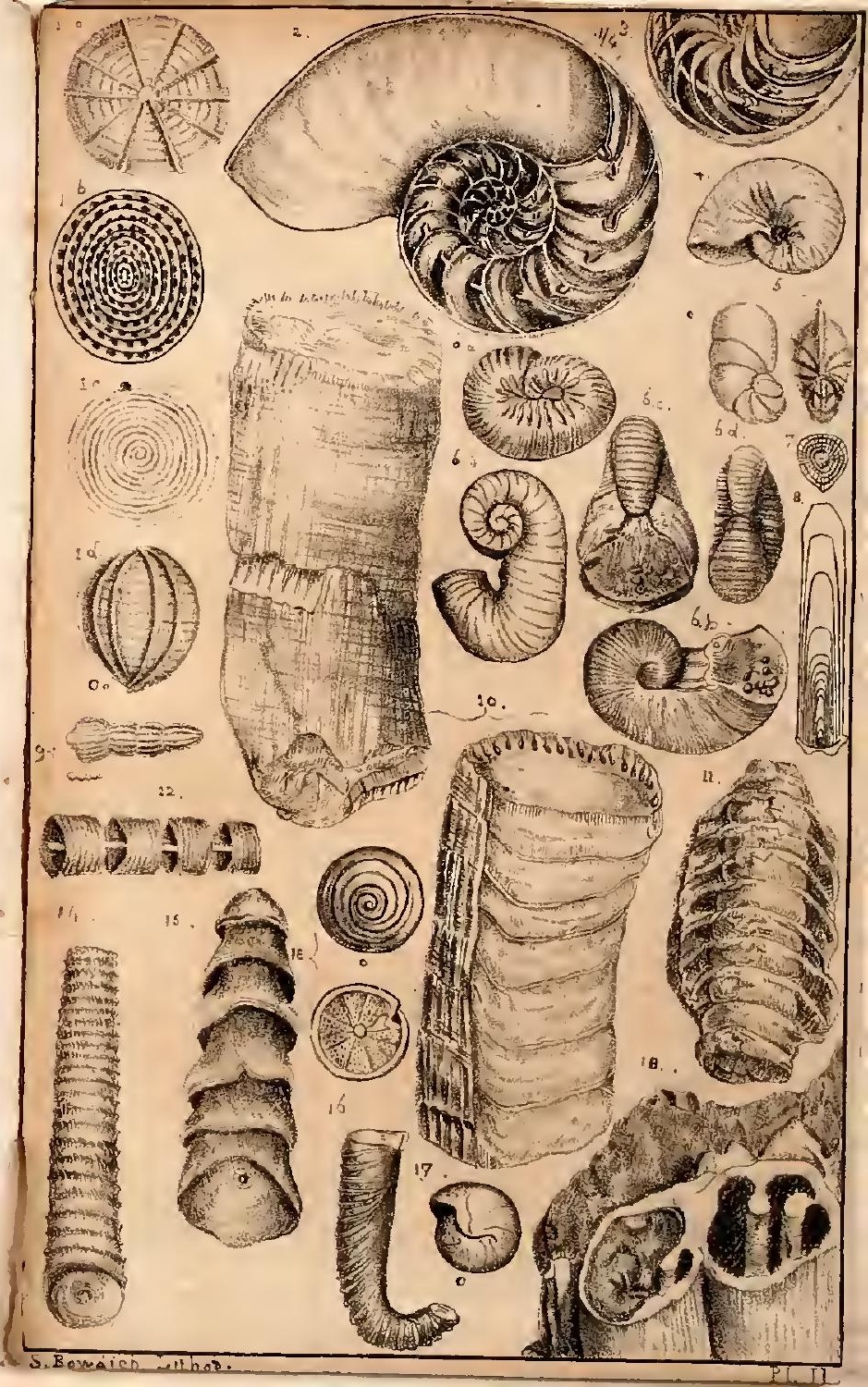





\section{PLATE III.}

1. Helix Lemani, in the $2 d$ Fresh-Water Formation.

2. Helix Menardi, in the limestone near Mans.

Second Fresh-Water Formation.

3. Oval grain found in the silex at Longjumeau.

4. Cylindrical, channelled grains, found in opaque silex at Longjumeau. They have no resemblance to any genus now known.

5. 6. Small cylindrical stems, with a channel in the centre, and divided by transverse partitions.

7. A body in the form of a date, with sinuous channels.

8. The ear of a plant (which may be compared to certain species of Paspalum) found in the silex at Longjumeau. 
9. Argonautites levis.

10. Vaginella depressa.

11. 12. Orbulites.

13. Cristellaria ........

14. Ammonaceratitês Lamarckii, 1-3d. s. siphon.

15. Ellipsolites compressus.

16. Pollontes vesicularis.

17. Arethusa corymbosa.

18. Baculites vertebralis. Montf.

19. Conularia quadrisulcata.

$20 . \quad$. teres.

21. $\therefore$ quadrisulcata.

22. Telebois annulatus.

23. Tiranites gigas. 

PLATE III.

Helix Lemani, in the $2 d$ Fresh-W ater Fornation.

Helix Menardi, in the limestone near Mans. Second Fresh-IFater Formation.

3. Oval grain found in the silex at Longjumeau.

Cylindrieal, ehannelled grains, found in opaque silex at Longjumeau. They have no resemblanee to any genus now known.

6. Small cylindrical stems, with a channel in the centre, and divided hy transverse partitions.

7. A body in the form of a date, with sinuous channels.

8. The ear of a plant (wlich may be compared to certain species of Paspalumi) found in the silex at Longjumean.
10. Vaginella depressa

11. 12. Orbulites.

13. Cristellaria

14. Ammonaceratitês Lamarckii, 1-3d. s. siphon.

15. Ellipsolites compressus.

16. Pollontes vesicularis.

17. Arethusa corymbosa.

18. Baculites vertebralis. Montl.

19. Conularia quadrisulcata.

20. . teres

quadrisulcata.

22. Telebois annulatus.

23. Tiranites gigas.

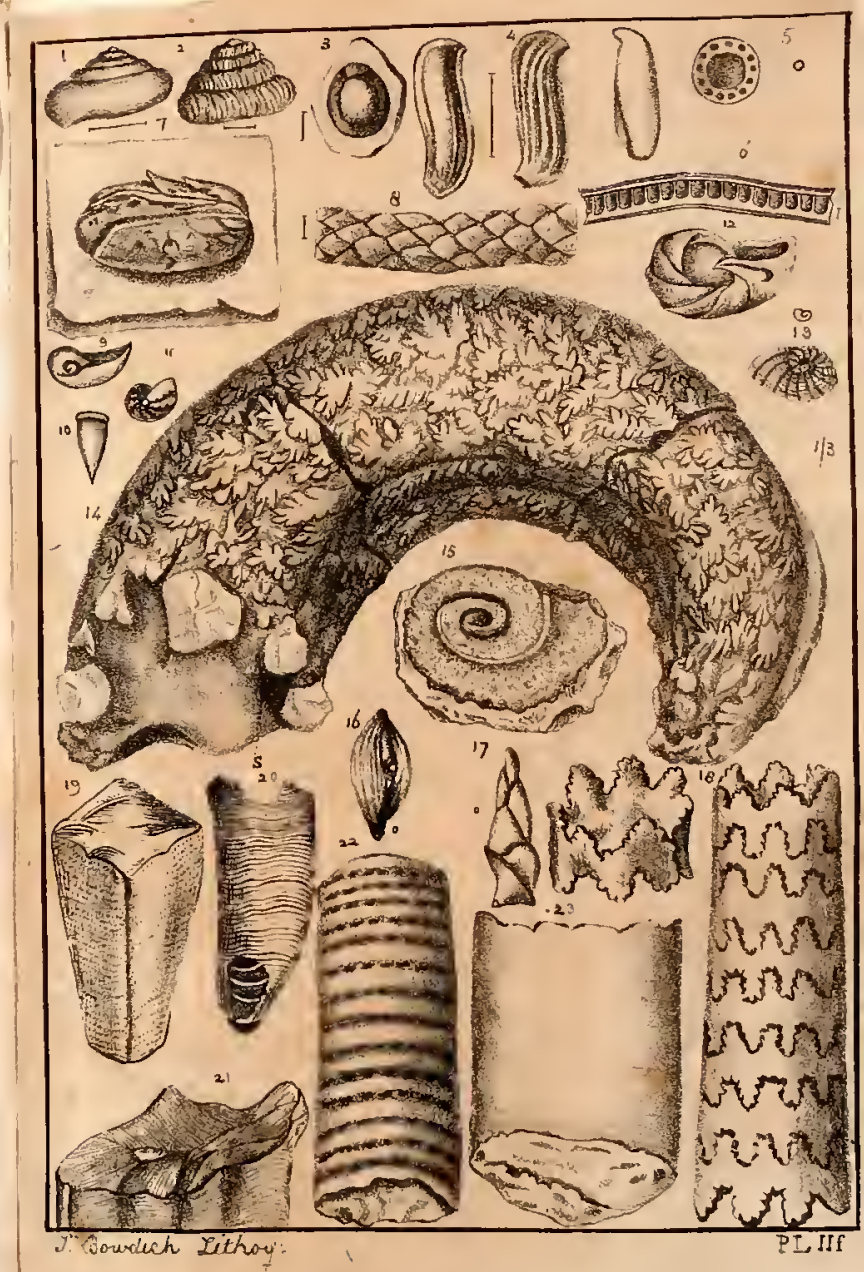





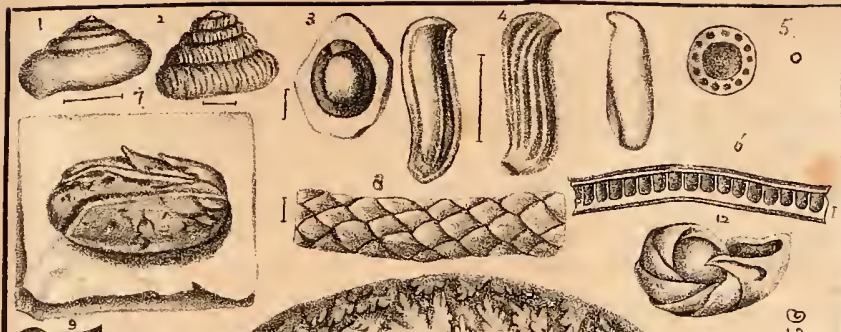

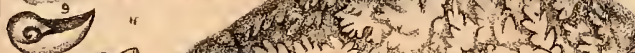

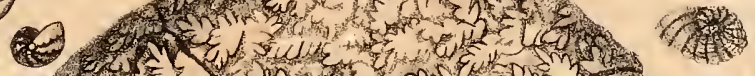

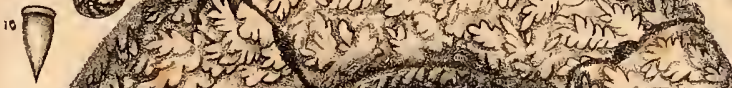

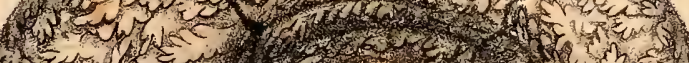

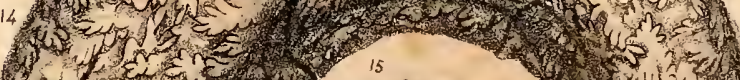

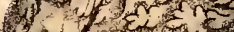

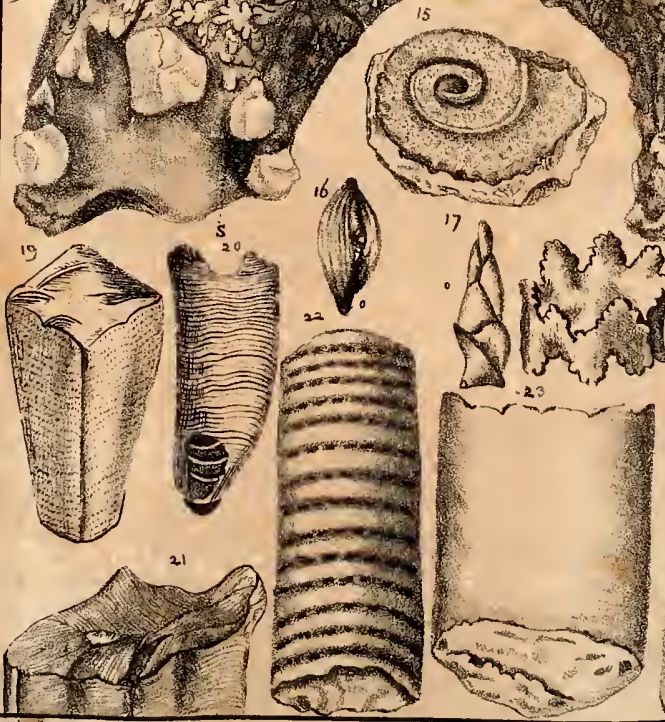

"1

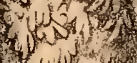
2. is ${ }^{3}(1)$.

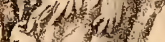

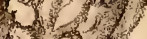
in $y^{2}$ $1 / 3$ 


\section{PLATE IV.}

First Fresh-Water Formation.

1. Cyclostoma mumia.

2. Lymnceus strigosus.

3. .. longiscatus.

4. .. acuminatus.

5. Planorbis lens.

6. An articulated stem (with projecting papillæ), resembling the root of an Equisetum. 
Second Fresh-Water Formation.

1. 2. Lymnaus ovum.

3. Bulimus pusillus.

4. .. atomus.

5. Cyclostoma elegans antiquum.

6. Potamides Lamarckii.

7. 8. Planorbis rotundatus.

9. cornu.

10. .. Prevostinus.

11. Lymnceus corneus.

12. .. Fabulum.

13. .. ventricosus.

14. ... enflatus.

15. Bulimus pygmseus.

15. . . terebra.

16. Lymnceus palustris antiquus.

17. Pupa Defrancii.

18. Helix Ramondi.

19. . Desmarestina.

20. . Cocquii.

21. . Moroguesi.

22. . Tristani. 



\section{- Plate iv.}

\section{First Fresh-Water Formation.}

1. Cyclostona mumia.

2. Lymuaus strigosus.

3. .. longiscatus.

4. .. acuminatus.

5. Planorbis lens.

6. An articulated stem (with projecting papille), resembling the root of an Equiselunt.
Second Frest-Water Formation.

1. 2. Lymneus ovum

3. Butimus pusillus.

5. Cyclostoma elegans antiquum.

6. Potamides Lamarckii.

7. S. Planorbis rotundatus.

9. . . cornu.

10. . . Prevostinus

11. Lymnaus corneus.

12. .. Fabulune.

13. .. ventricosus.

14. .. enflatus.

15. Bulinus pygmıeus.

15. . terebra.

16. Lymnneus palustris antiquus.

17. Pupa Defrancii.

18. Helix: Ramondi

19. . Desmarestina.

20. . . Cocquii.

21. . Moroguesi.

22. . Tristani.

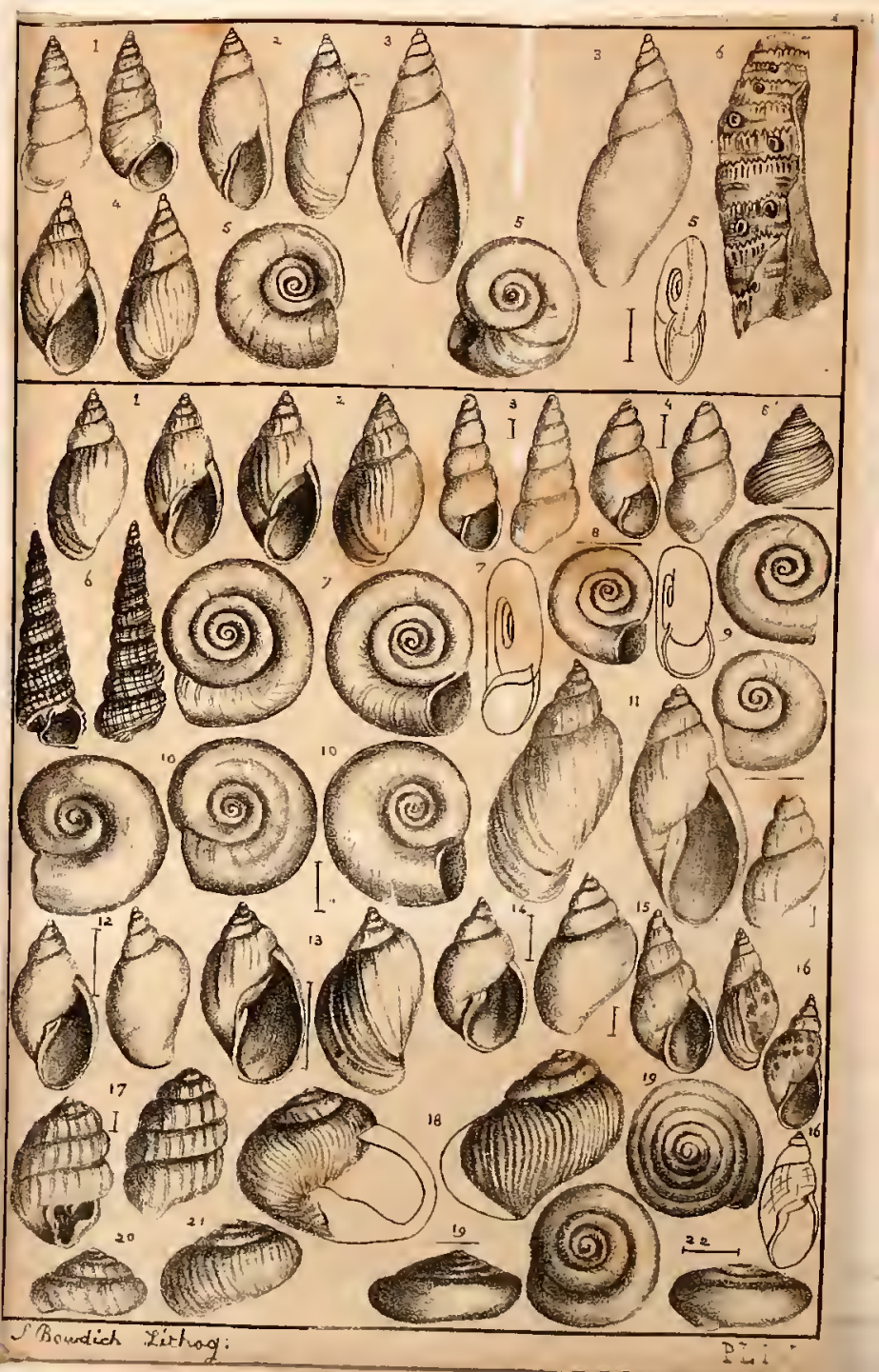






\section{PLATE V.}

1. Hyalea tricuspidata.

2. Cleodora pyramidalis.

3. Cymbulia proboscidea.

4. Parmaphora elongata.

5. Patella elongata.

6. .. cornucopia.

7. Ancylus fluviatilis.

8. Upper and under view of the Calyptrcea equestra.

$9 . \quad \ldots \quad \ldots \quad$ of the Testacella haliotidea.

10. Fissurella (Patella Greca, List.).

11. Emarginula clypeata.

12. Under and side vicw of the Crepidula porcellana.

13. ... . of the Capules tortus.

14. Vitrina pellucida. 
15. Umbrella Indica.

16. Carinaria vitrea.

17. Dolabella.

18. Bullera.

19. Bulla aperta.

20. Infundibulum echinulatum.

21. Stomatia phymotis

22. Stomatella imbricata.

23. Septaria seu Navicella (Patella Borbonica).

a. Back view.

$b$. Under ..

c. Side . .

d. Operculum.

24. Halyotis vulgaris.

25. Sigaretus concavus.

Some of the figures in this Plate are inadvertently reversed. 




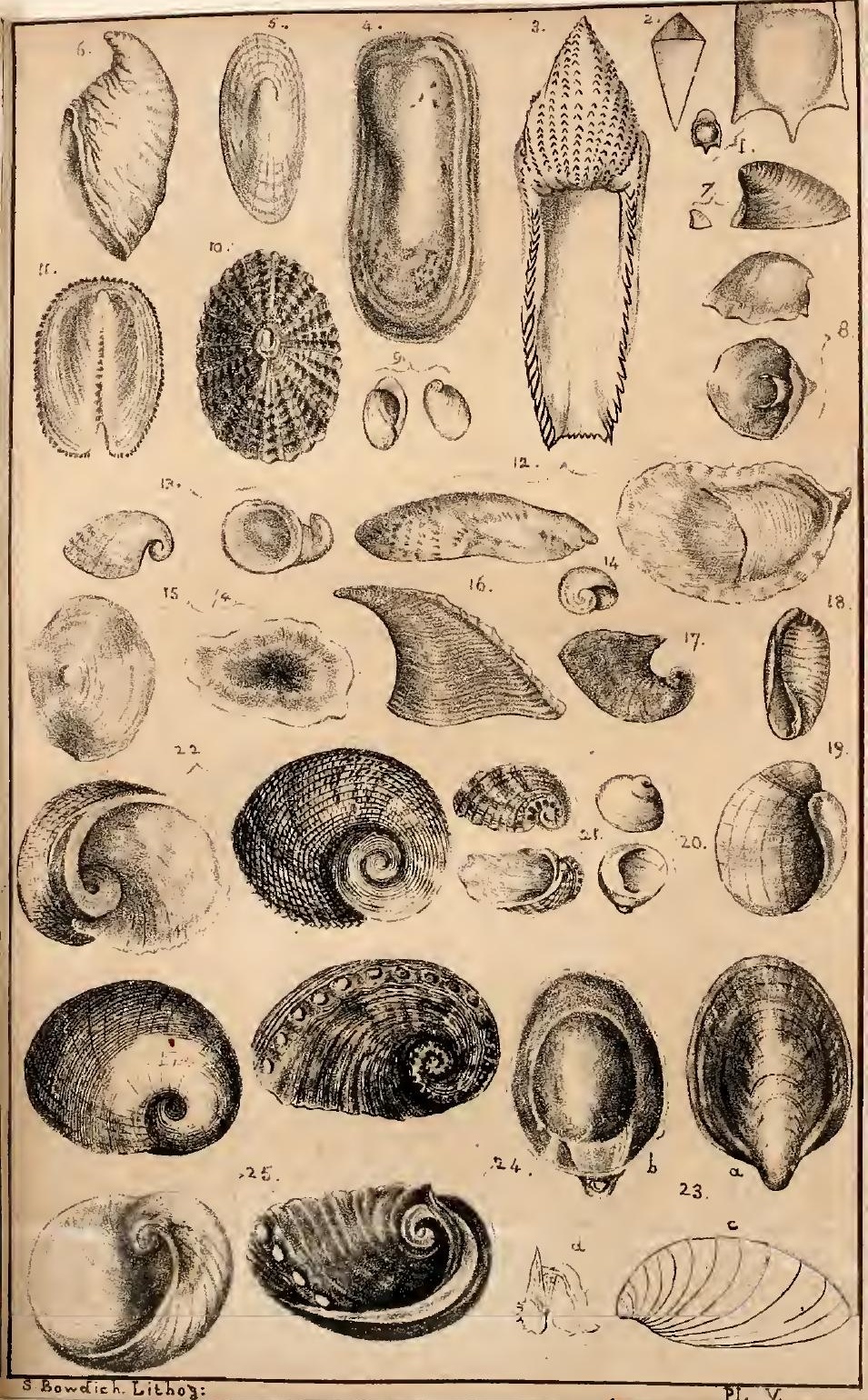




\section{PLATE VI.}

1. Hipponyx comucopice. Defr.

a. In profile, 1-2.

b. Shewing the support within, 1-2.

c. In profile, without the support, 1-2.

d. Seen within.

$e$. On its support, as it was found.

$f$. The support seen within.

g. Hipponyx mitrata, Defr. a recent shell, with its support.

h. Hipponyx cornucopice, shewing the mouth.

2. Plectrophorus costatus, Feruss.

3. . orbignii, Feruss.

4. Padollus scalaris, Leach.

5. Ambrette Succinea, Drap. (Amphibulima, Lam.)

6. Amphibulima, Lam.

7. Testacellus ambiguus, Feruss.

8. . . haliotideus, Feruss.

9. .. Maugei, Feruss.

10. Parmacella Olivierii, Feruss.

11. Helicarion Cuvierii, Feruss.

12. Lymnceus stagnalis.

13. Physa N. Hollandica. 
14. Melania.

15. Melantho.

16. Melania amarula.

17. Melanella Dufresnii.

18. Melanopsis.

19. Melanamona.

20. Pyrene, Lam. Melanatria.

21. Phasianella picta.

22. Auricula Judcea.

23. Scarabus imbrium, I. each.

24. Carychium undulatum. Leach.

25. Conovula coniformis.

26. Achatina Virginiana.

27. Bulimus radiatus.

28. Bulimulus trifasciatus.

29. Tornatella fasciata.

30. Helicina neritella.

31. Bulinus auris-leporis (monst.).

32. Planorbis.

33. Bulinnus ovularis.

34. Pupa modiolinus.

35. Bulimus auris-leporis..

36. Clausilia.

37. Pupa.

38. Bulimus decollalus. 



\section{PLATE VI.}

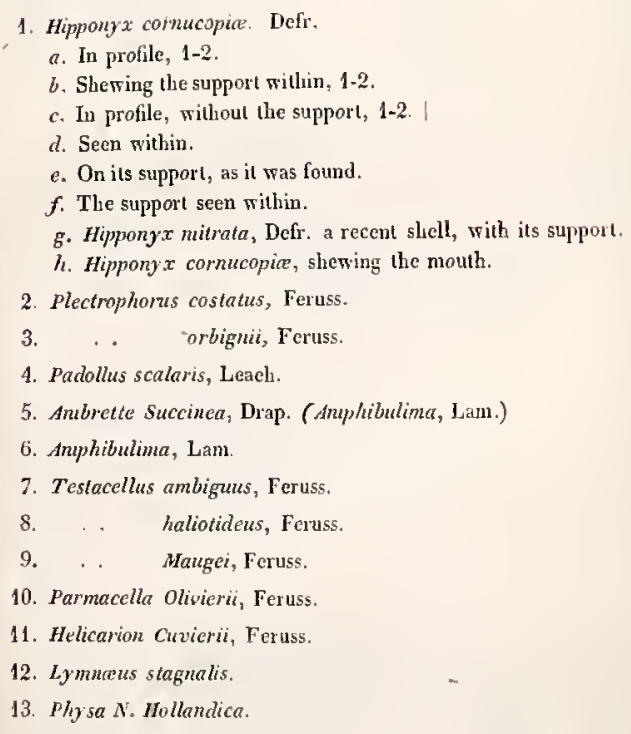

12. Lymureus stagnalis.

13. Physa $N$. Hollandica.

14. Melenia.

15. Ifelantho.

15. Melania amarula.

17. Melanella Dufresnit.

18. Melanopsis.

19. Melanamona.

90. Pyrene, Lam. Melanatra.

21. Phasianella picta.

29. Auricula Judea.

93. Scarabus imbrium, Leach

24. Carychiun undulatum. Leach.

25. Conovula coniformis.

26. Achatina Virginiana

27. Bulinus radiatus.

28. Bulimulus trifasciatus.

29. Tornatella fasciata.

30. Helicina neritella.

31. Bulimus auris-leporis (monst)

32. Planorbis.

33. Bulimus ovularis

34. Pupa modiolinus.

35. Bulinus auris-leporis.

36 Clausiline.

37. Pupa.

38 Bulimus decollutus. 



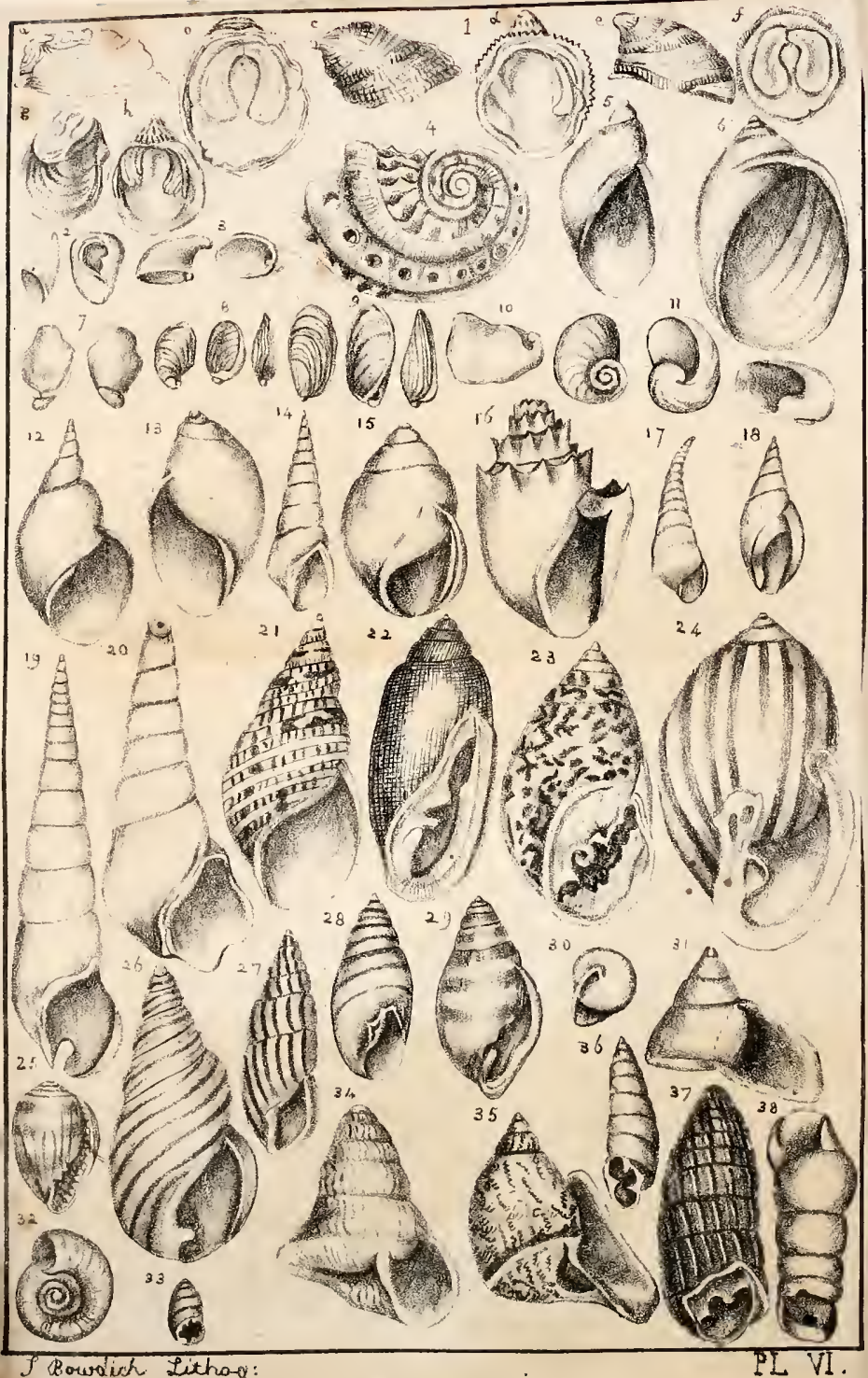




\section{PJATE VII.}

1. Helico-Limax elongata, Feruss.

2. Helix brevipes, Drap.

3. 4. Cornu giganteum, Chemn. in the young and in the adult state; one of the smaller figures represents the egg entire, and the other the animal in its shell coming out of the egg: 1-2 the natural size.

5. Bulinus patulus, Brug. (Amphibulima cucullata, Lam.)

6. .. . . in the young state.

7. Helix naticö̈des, Drap.

8. . . Listeri, Feruss.

9. . . ligata, Muller.

10. ... deformis, Feruss. 

11. Helix aspersa, Muller.
12. 13.14. . . . (monstrosities).
15. Pouchet Adans (Turbo variegatus, List.)
16. Helix alonensis, Feruss.
17. Helix plicata, Lin.
18. .. aspersa, List.
19. . . carabinata, Feruss.
20. . . ringens (Tomigeres ringens, Leach. Anostoma, Lam.).
21. . . imperator (Polydontes imperator, Montf.).
22. . . carocolla, Chemn. (Carocolla, Lam.)
23. . . sorora, Feruss. 



\section{PIATE VII}

1. Hclico-Limax elongala, Feruss.

2. Helix brevipes, Drap.

3. 4. Cornu giganleum, Chemn. in the young and in the adult state; one A. the smaller figures represents the egg entire, and the other the animal in its shell coming out of the egg: 1-2 the natural size. 5. Bulimus patulus, Brug. (Amphibulima cucullata, Lam.)

6. . . . in the young state.

7. Helix naticoides, Drap.

8. . . Listeri, Feruss.

9. . ligata, Muller.

10. . . deformis, Feruss.
11. Helix aspersa, Mulles.

13. 14. . . (monstrosities).

5. Pouchet Adans (Turbo variegalus, List.)

16. Helix alonensis, Feruss.

17. Hclix plicata, Lin.

18. . . aspersa, List.

19. .. carabinata, Feruss.

. . ringens (Tomigeres ringens, Leach. Anostoma, Lam.)

intperator (Polydontes imperator, Montf.)

22. . . carocolla, Chenn. (Carocolla, Lam.)

23. . . sorona, Feruss.

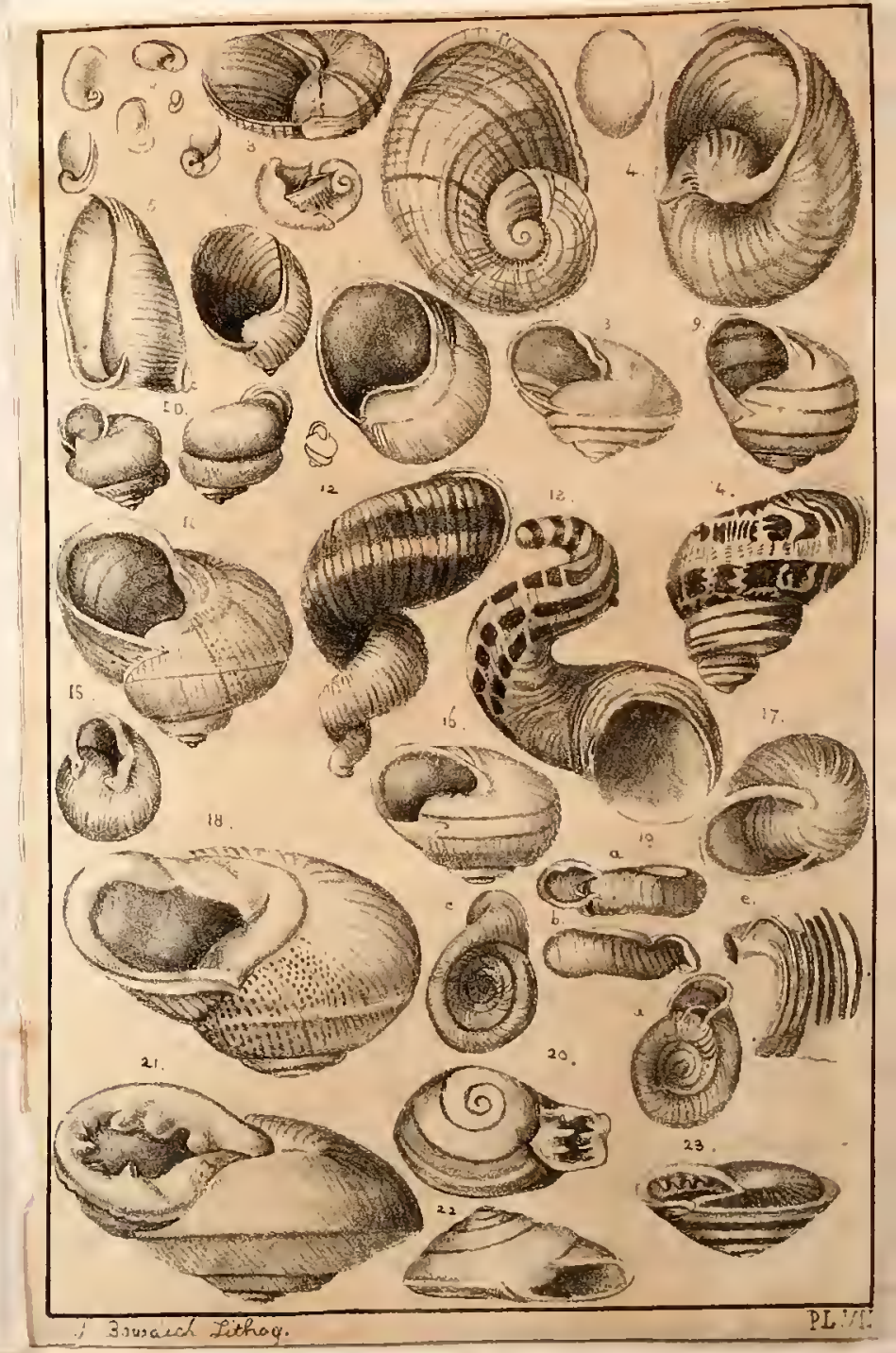





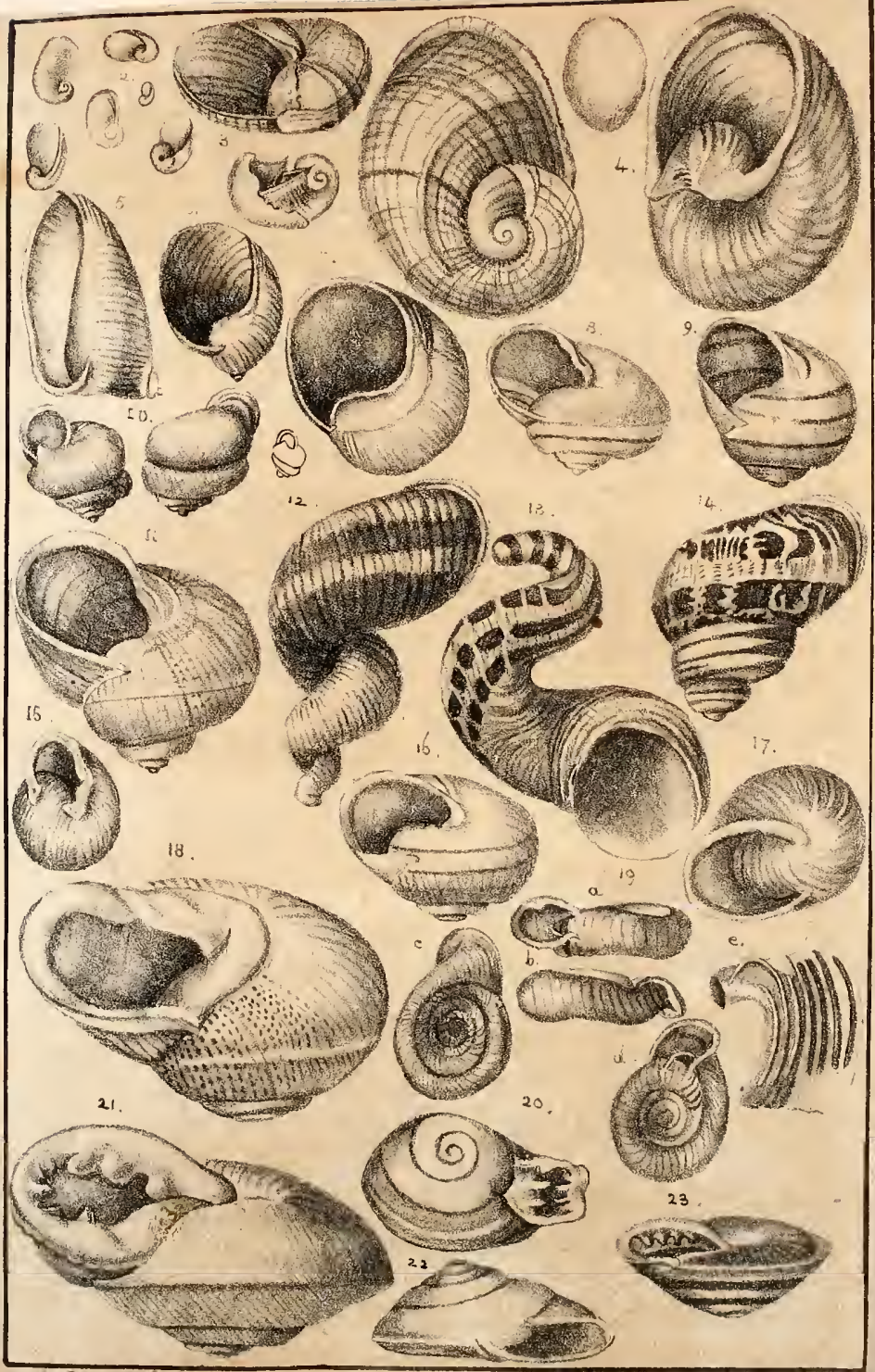




\section{PLATE VIII.}

1. 2. Helix pyrostoma, Feruss.

3. .. Madagascariensis, Lam.

4. Helicella lavipes, Feruss. Helix spadicea, Gmel.

5. Helix sub-dentata, Feruss.

6. . albella, Chemn. side view.

7. . planata, Chemn.

8. Helicella sepulcralis, Feruss.

9. Helix ochroleuca, Feruss. Helix albella, Chemn.

10. . . epistylium, Gmel.

11. . . strobilus, Feruss.

12. . . nitida, Drap.

13. Cyclostoma bulimoödes, Oliv.

14. Melania buccinoïdea.

15. Cyclostoma unicolor, Oliv.

16. Bulinıus labrosus, Oliv.

17. Melania costata, Oliv.

18. Helix villosa, Drap. 
19. Bulimus acicula, Drap.

20. Buccinum majus, List. (Kambeul, Adanson.)

21. Bulimus Dufresnii, Leach.

22. Bulla helicoüdes, Brocchi.

23. Bulimus montanus, Drap.

24. Pupa quadridentata, Drap.

25. . . granum, Drap.

26. Helix regina, Feruss. Achatina, Lam.

27. - frater, Feruss.

28. Cyclostoma Odostomia. (Auris Mida, etc. Chem.)

29. Pupa fragilis, Drap.

30. Partula australis, Feruss. (Auris Midoe fasciata, etc. Chemn.)

31. Cochlodina Blainvilliana, Feruss. (Cyclostoma, Lam.)

32. Pupa modiolus.

33. Clausilia plicata, Drap.

34. Pupa edentula, Drap.

35. . . vertigo, Drap.

36. . . antivertigo, Drap. 

19. Bulimus acicula, Drap

10. Bucciumm majus, Lisl. (Kanlbeul, Adanson.)

21, Bulimus Dufresnii, Lcach.

22. Bulla helicoìdes, Brocchi.

23. Bulimus montanus, Drap.

24. Pupa quadridentata, Drap.

25. . g gianum, Drap.

26. Helix regina, Feruss. Achatina, Lam.

27. - frater, Feruss.

28. Cyclostoma Odostonia. (Auris Midke, etc. Chem.)

29. Pupa fragilis, Drap

30. Partula australis, Feruss. (Auris Mide fasciatr, etc. Chemn.)

31. Cochlodina Blainvilliana, Feruss. (Cyclostoma, Lam.)

32. Pupa modiolus.

33. Clausilia plicata, Drap.

34. Pupa edeniula, Drap.

35. . vertigo, Drap.

36. . . antivertign, Drap.

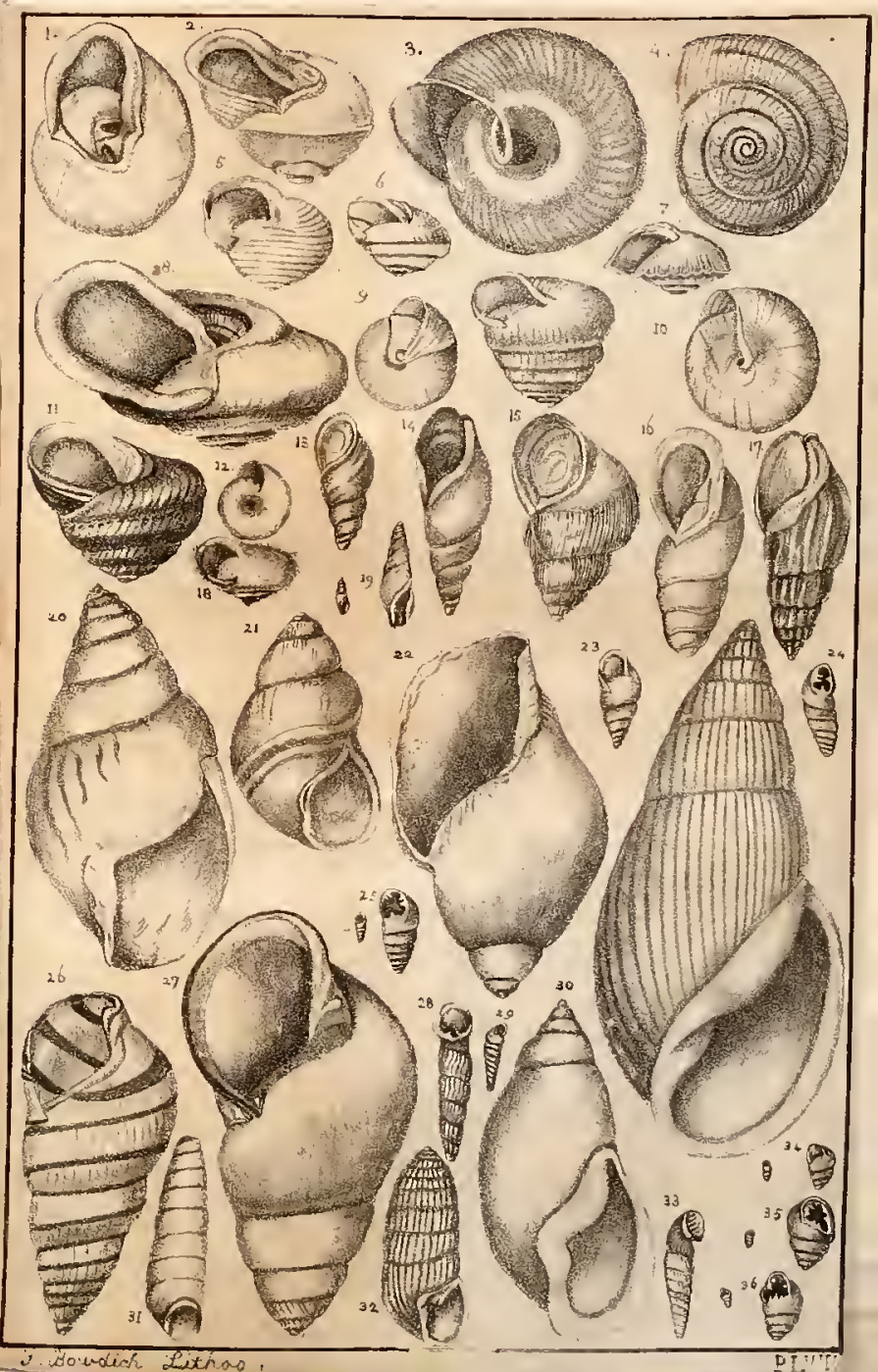





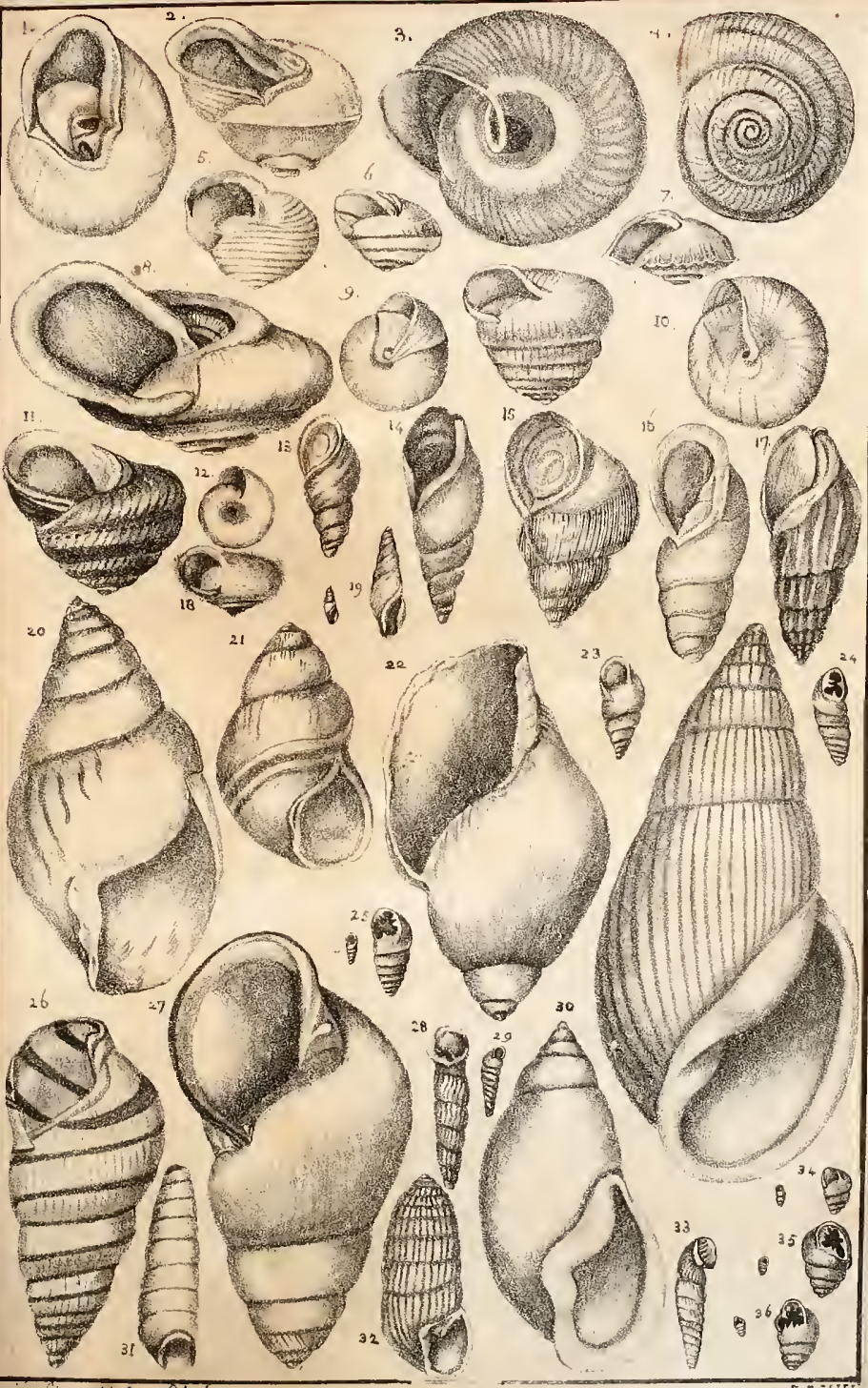




\section{PLATE IX.}

1. Ampullaria.

2. Ampullina.

3. Turbo picta, with its operculum.

4. Cirrus acutus, Sowerby.

5. Aciona scalaria (Wendletrap), Leach.

6. Scalaria clatrata.

7. Trochus crenularis.

8. . agglutinans, with and without the adhering substances.

9. . . imperator (Imperator coronatus, Montf.)

10. . calcar.

11. Solarium perspectivum.

12. Turrilella. 
13. Cyclostoma mumia.

14. .. elegans.

15. Paludina fasciata (Helix vivipara, Lin.)

16. Delphinula.

17. Vermetus, Adans.

18. Euomphalus pentangulatus,
19.

20. Nerita Malaccensis, and its operculum.

21. Neritina zebra.

22. Valvata spirorbis, Drap.

23. Clithoin coronata.

24. Natica.

25. Monodonta.

26. Ianthina fragilis. 

PLATE IX

1. Ampullaria.

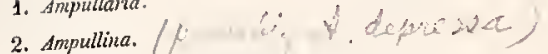

3. Turbo picta, with its operculum.

4. Cirrns acutus, Sowerby.

5. Aciona scalaria (W'endletrap), Leach

6. Scalaria clatrata.

7. Trochus crenularis.

8. .. agglutinans, with and without the adhering substances.

9. .. imperator (Imperator coronatus, Montf.)

10. . calcar.

11. Solarium persnectivnm.

12. Turritella.
13. Golostoma munia

14. .. elegans.

15. Paludina fasciata (Htolix viripara, Lin.)

16. Delphinula.

17. Vermelus, Adans.

18. Euomphalus pentangulatus, \}Sorrerby.

20. Nerita Malaccensis, and its operculum.

21. Neritina sebra.

22. Valvata spirorbis, Drap.

23. Clithon coronata.

24. Natica.

25. Monodonia.

26. Ianullina frugilis.

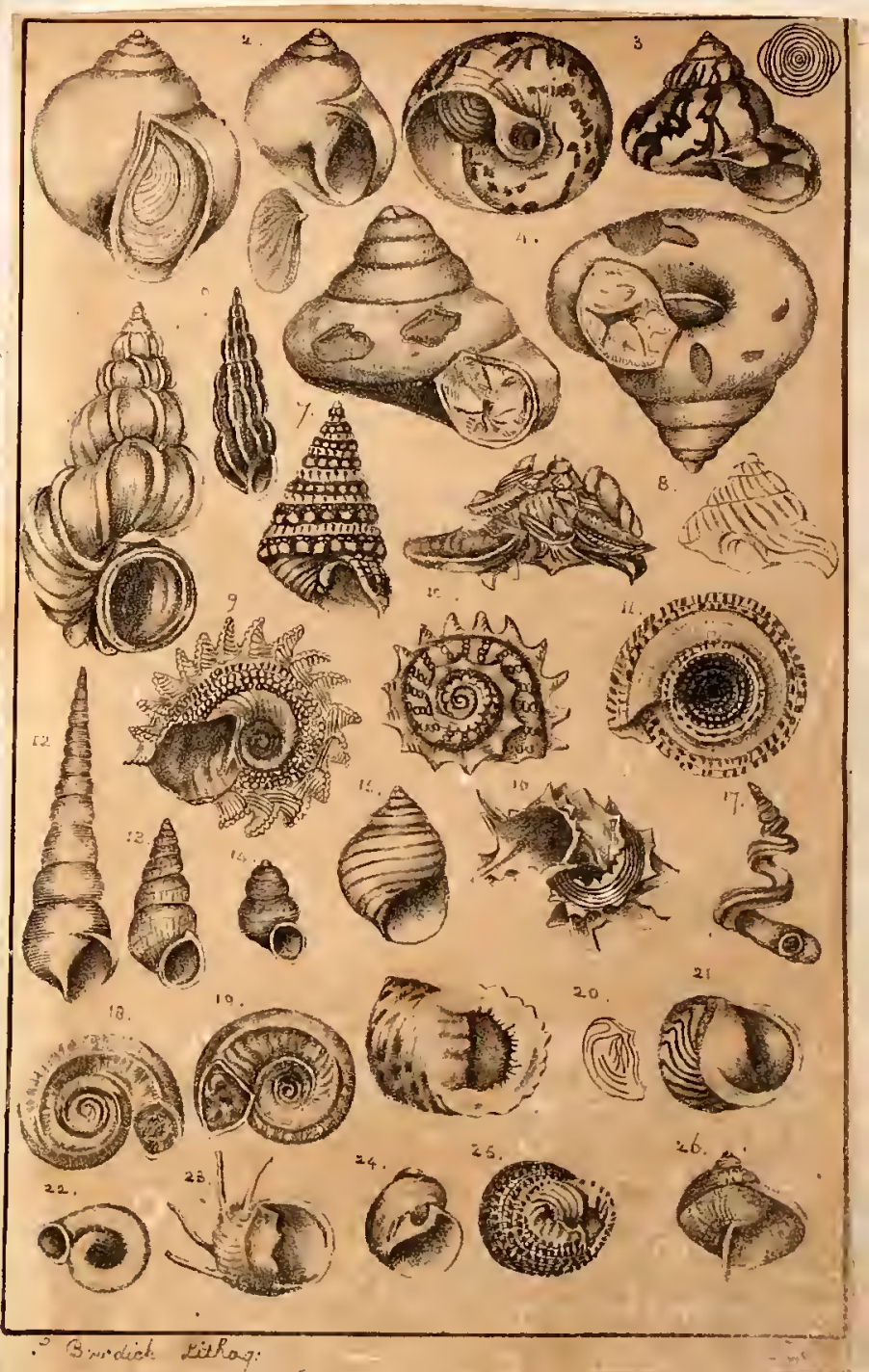





\section{PLATE X.}

1. Murex lampas.

2. . Tritonia.

ว. . Brandaris.

4. Tritonia Allantica, Montf.

5. Murex frondescens.

6. Ranella Buffonia.

7. Fusus.

8. Pyrula melongena.

9. Eburna areolata.

10. Ancillaria cinanomea.

11. Mitra. 
12. Pyramidella dolabrata.

13. Pleurotoma tigrina.

14. Fasciolaria tulipa.

15. Turbinellá scolyma.

16. Rostellaria subulata.

17. Concholepas Peruviana.

18. Potamides Lamarkii.

19. Cerithium.

20. Terebra lanceolata.

21. Buccinum undatum.

22. Dolium variegatum.

23. Nassa Thersita. 

19. cerithium

no. Terelra lanceolata. 



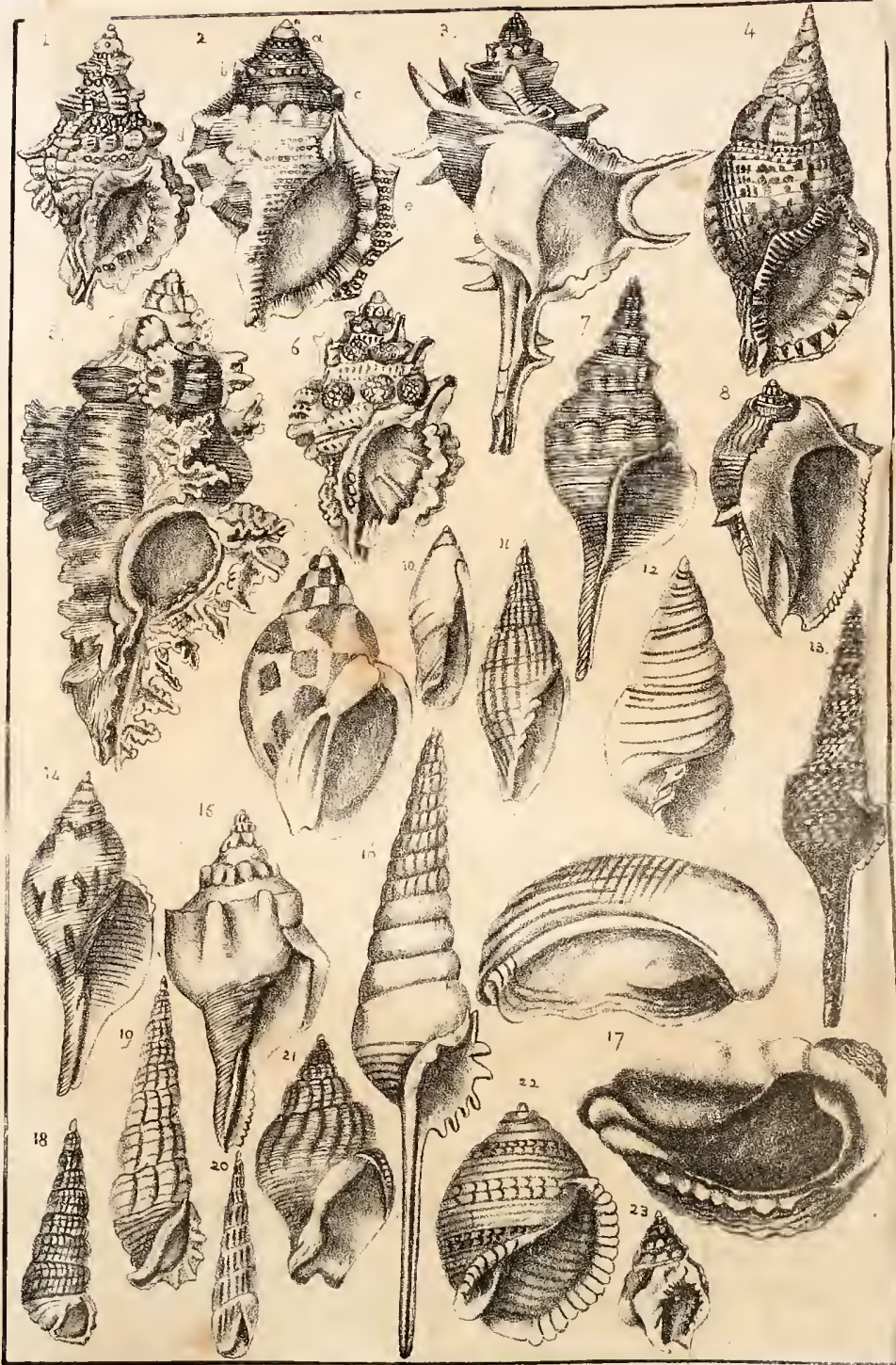




\section{PLATE XI.}

1. Harpa mutica.

2. Purpura patula.

3. Monoceros.

4. Ricinula horrida.

5. Cassidaria echinophora.

6. Cancellaria reticulata.

7. Cypraa moneta.

8. Ovula gibbosa.

9. a. Cypreec in the infant state.
b. .. .. middle ..
c. .. .. adult .

10. Ovula oviformis. 
11. Cassis glauca.

12. .. harpaformis.

13. Oliva litterata.

14. Terebellum punctatum.

15. Strombus pugilis.

16. Pterocera lambis.

17. Colombella hilaris.

18. Volvaria monilis.

19. Marginella bimarginata.

20 . . . sub-carulea.

21. Conus nocturnus.

22. . betulinus. 

1. Harpa mulica.

2. Purpura patula

3. Monoceros.

4. Ricinula horrida.

5. Cassidaria cchinophora.

6. Cancellaria reticulata.

7. cyprea moneta.

8. Ovula giblosa.

9. a. Cyprea in the infant state.

b. .. .. middle..

c. .. .. adult

10. Osula oviformis.
3

17. Colombella hilaris.

18. Volvaria monilis.

19. Marginella binarginata

20. . . sub-ccrulca.

21. Conus nocturnus.

22. . betulinus.

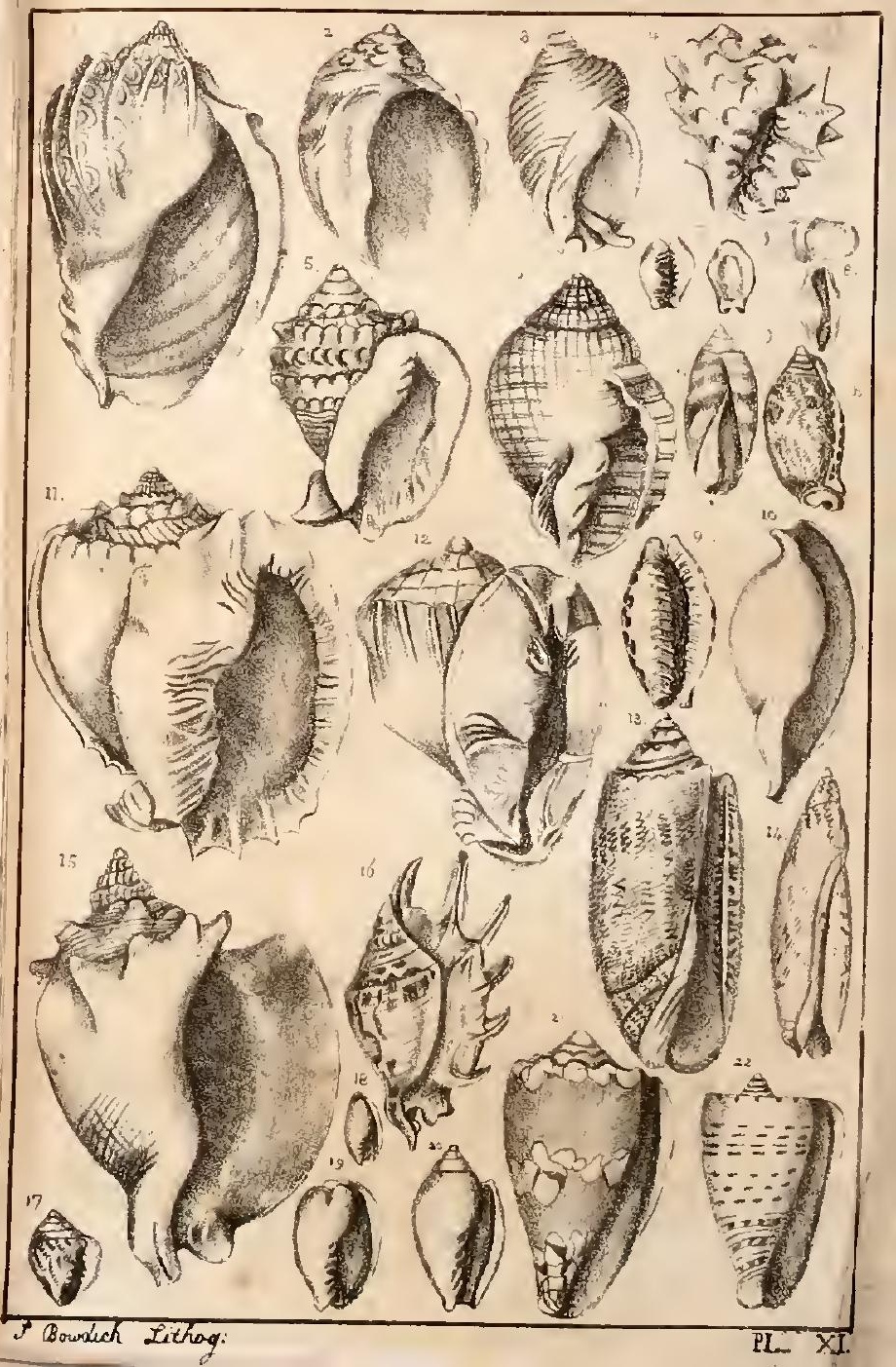





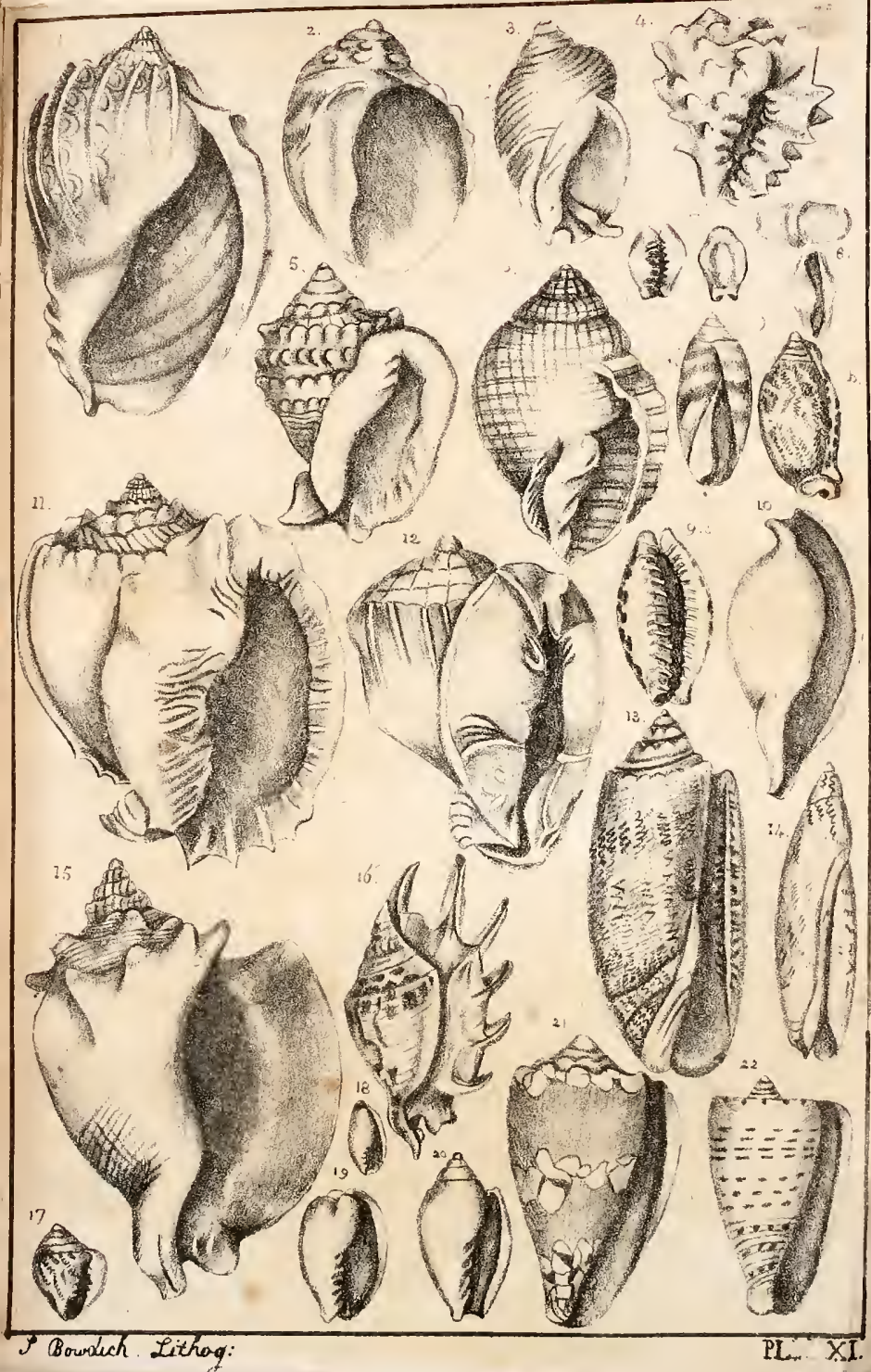




\section{PLATE XII.}

1. Conalix lineatus, Swainson.

2. Voluta rugifera seu musica.

3. . volvacea.

4. . vespertilio.

5. . olla.

6. Helicina neritella.

7. Murex tubifer.

8. Bulimus sebra, Oliv.

9. Struthiolaria Lamarckiz. 
10. Helix crenelata, Oliv.

11, Polyphemus Bruguireus.

12. Ampullaria (found in bituminous marl above a mine of fossil coal.

13. .. compressed laterally; giving it an accidental, elongated form.

14. .. . . vertically; changing the form of the mouth, and

15. Turbo lugubris, Chemn. giving it the appearance of another species.

16. Section of a Pyramidella, to shew the columella.

17. Turritella. (au jour).

18. Cyclostoma bulimoïdes, Oliv. 

10. Helix crenelata, Oliv.

11. Polyphomus Bruguireus.

12. Ampullaria (found in biluminous marlabove a mine of fossil coal.

13. . compressed laterally; giving it an aceidental, clongated form.

14. . . vertieally; ehanging the forn of the nnouth, and

15. Turbo lugubris, Chemn. giving it the appearance of another species.

1. Conalix lineatus, Swainson.

2. Voluta rugifera sen musica.

3. . volvacea.

4, .. vespertiliv.

5. . ollu.

6. Helicina neritella.

7. Murex tubifer:

8. Bulimus zelra, Oliv

9. Struthiolaria I.amarckit. (au jouv)

18. Cyclostoma bulinoödes, Oliv.

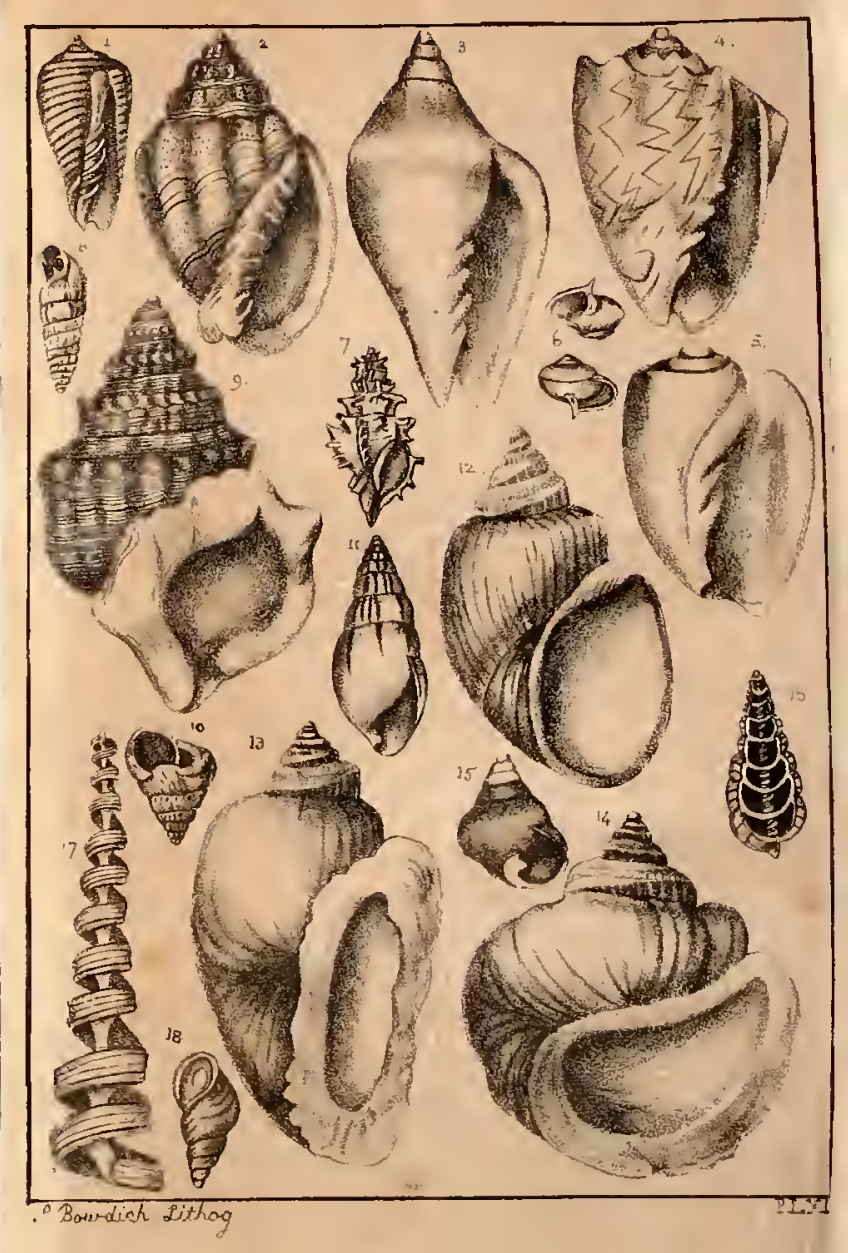





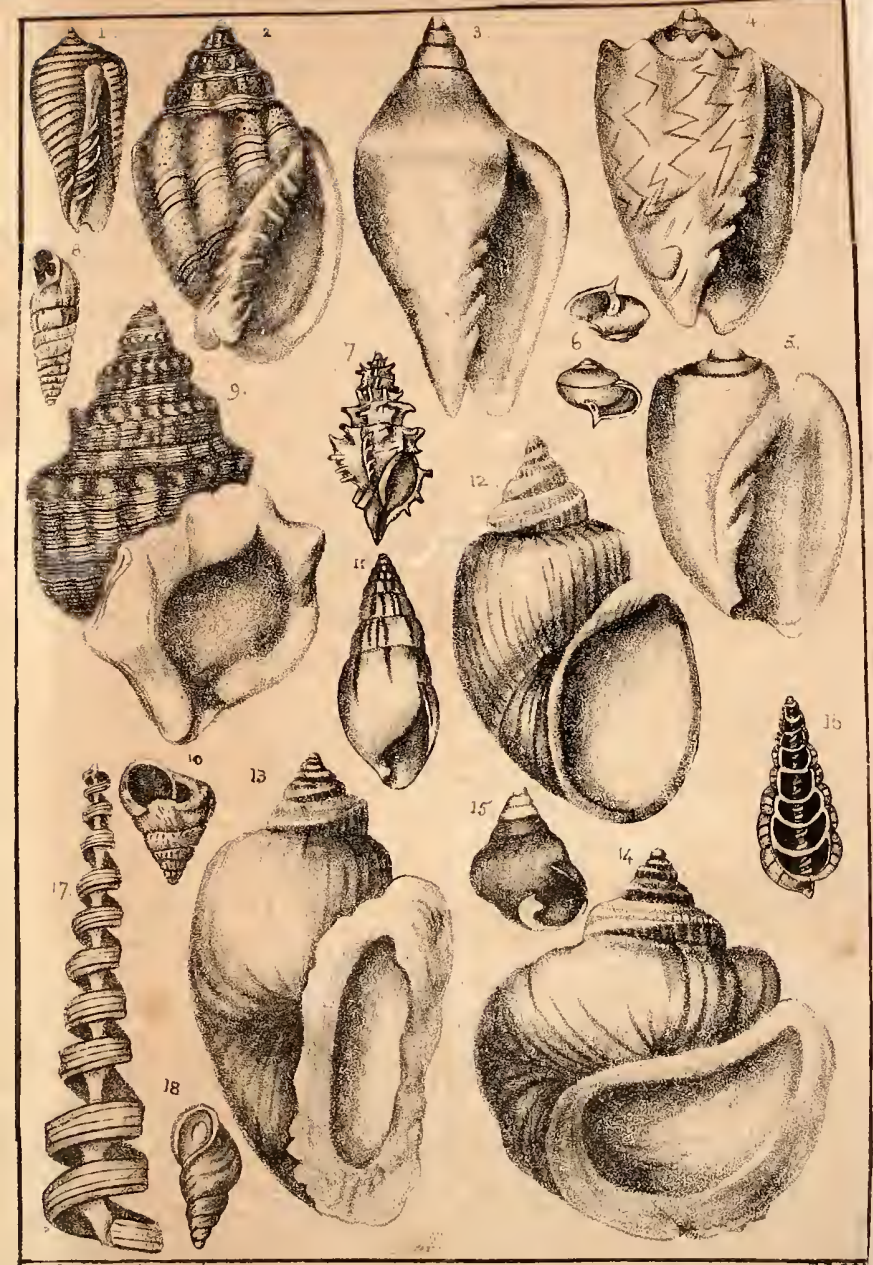

"Bondich Lithoo: 


\section{PLATE XIII.}

1. Helix unidentata, Chemn.

2. Cerithium gigas, 1-4th.

3. Achatina fulica, Lam.

4. Argonauta.

5. Aplysia.

6. Dolabella.

7. Interior mould of a Cerithium gigas, 1-4th.

8. Clavatula scabra.

9. Cyclostoma carinata, Oliv.

10. Melania marginata.

11. Helix conoüdea, Drap.

12. Pupa avena, Drap.

13. Melania cochlearella.

14. . . costellata.

15. Bulimus terebraster.

16. Buccinum Barbadense, Lister.

h. The head.

tt. . . tentacula.

m. .. mouth.

T. .. trunk.

ec. .. eyes.

f. .. foot.

o. .. operculum. 
17. Cerithium. (Buccinum Africanum, Listcr.)

$h$. The head.

tt. .. tentacula.

m. .. mouth.

ee. .. eyes.

$T$. .. trunk.

f. ... foot.

o. .. operculum.

18. Limax phosphorescens, 1-2.

19. 20. Yetus, Adans. (Buccinum Persicum, Lister.)

h. The head.

tt. .. tentacula.

m. .. mouth.

ee. .. eyes.

T. .. trunk.

$k$. .. extremity of the mantle, forming a sort of pipe.

nn. .. membrane accompanying the mantlc.

$f$. A part of its enormous foot.

21. Halyotis.

h. 'The head.

$t t$. .. four tentacula.

ee. .. eyes.

n. .. membrane which attaches the lower tentacula to the head.

l. .. two anterior extremities of the mantle, coming out of the second hole of the shell. 




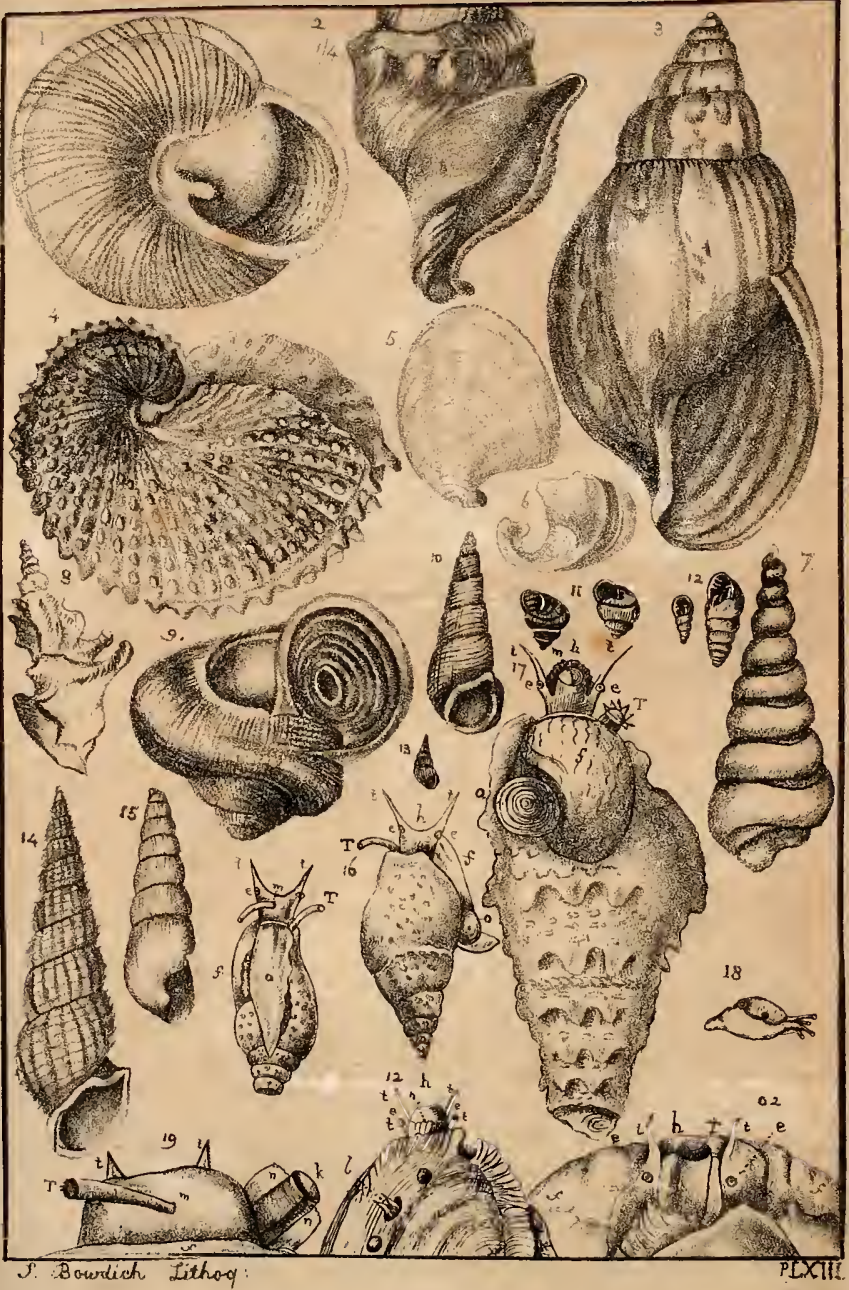


1. The hearts of the Calmar.

$a$. The hollow vein.

bb. .. lateral hearts.

cc. .. pulmonary arteries.

2. The heart of the Aplysia.

$a$. The hollow vein.

d. .. branchiæ.

3. Spirula fragilis with its shell.

4. Tapada putris, with its shell.

5. The under side of a Patella, the head bent towards the foot.

a. The foot.

b. .. mouth.

cc. .. tentacula.

d. .. anus and orifice of generation.

$f$. .. heart.

g. .. arteries.

e. The pericardium. vein.

hh. .. branchix. $d d$. The place of the branchix.

ee. .. pulmonary veins.

$f$. .. middle heart.

gg. .. aorta.

$e$. The auricle and pulmonary vein.

$f$. .. trunk of the branchial vein.

ggg. .. circular part of the above

ii. .. branchial artery.

6. A Patella of the species in which the branchix are interrupted.

a. The mouth.

bb. .. tentacula.

c. .. fleshy mass.

d. .. nervous collar.

f. .. ovarium.

gg. The intestines.

h. .. branchia.

ii. .. branchial veins.

$q q$. .. oviductus.

7. Helix brevipes, with its shell.

8. Hyalea australis, with its shell seen on the side of the projecting valve. $a . b . c$. The projecting points of the flat or ventral valve.

d. The dorsal valve.

$f f$. .. mantle coming out from the interstice between the valves, close to which are the branchiæ.

l. $m$. .. fins.

n. .. mouth.

9. Parmacella Olivieri, Cuv. opened.

$a$ : The mouth.

bb. .. great horns.

c. .. brain.

d. .. salivary glands.

e.ff. .. organs of generation.

g. .. bag for the colouring $o_{0}$..

h. .. stomach.

ii. The retracting muscles.

$k k$. .. liver.

l. .. lungs.

$m$. .. auricle.

n. .. heart.

z. .. mantle turned back.

10. Calmar (Sepia Loligo).

$a$. The head.

b. .. eyes.

c. .. fect.

d. .. arms.

e. The funnel.

$f$. .. abdomen.

g. .. fins. 
11. Brain of the Polypus;

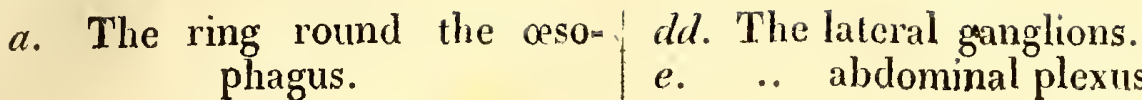

b. .. brain.

e. .. abdominal plexus.

cc. .. optical ganglions.

11.* Brain of the Aplysia.

a. The ring round the oesophagus.

b. .. brain.

e. .. abdominal ganglion.

12. The animal and shell of the Helico-Limax elongata.

13. Janthina penicephala, with its vesicular appendage (spuma carlilaginea) attached to the posterior part of the foot.

14. Aplysia.

a. The head.

b. .. inferior tentacula.

c. .. superior ..

d. .. eyes.

e. .. mantle.

$f$. .. operculum of the branchiæ.

15. The female Sigaretus seen underneath : the head and foot a little bent, to shew the entrance of the branchial cavity.
$a$. The notch.
I $b$. The anus.

16. The male Sigaretus seen underneath.

$a$. The notch.

bb. .. tentacula.

cc. .. foot.

17. Carinaria Mediterranea.

18. Plectophorus with its shell.

19. The female Vivipara taken out of its shell.

a. The foot partly folded in two.

b. .. operculum attached to the posterior part.

c. .. head with the tentacula and trunk.

d. .. little siphon prolonged under the right tentaculum.

e. .. lateral membrane of the left side.

$f$. .. edge of the mantle.

g. A small portion of the branchiæ shewing itself from underncath.

$h$. The orifice of the womb and anus.

20. Halyotis, drawn from the living animal, with all its ornamcnts. 

PLATE XIV

1. The hearts of the Calmat. $a$. The hollow vein.
$b b$. . latcral hearts.

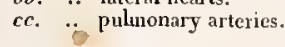

2. The heart of the Aplysia a. The hollow vein.
d. . branchix.

dd. The place of the branchix.
$e e$. .. pulmonary vemins. $\begin{array}{lll}f . & . & \text { pulmonary veins. } \\ g_{g} . & . & \text { niddle lieart. }\end{array}$

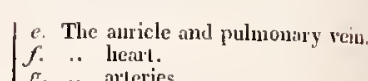

3. Spirula fragilis with its shell.

5. The under side of a Patella, the head bent towards the foot.

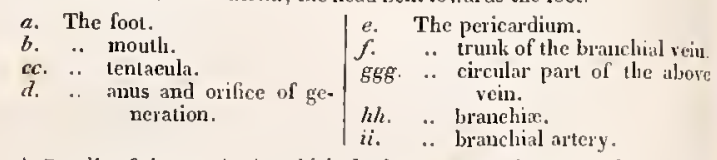

6. A Patella of the species in which the branchix are interrupted.
$a$. The mouth.
$b b$. . tentacula.
c. .. fleshy mass.
fg. The intestines.
d. .. nervous coll
$\begin{array}{lll}i i . & . . & \text { branclial yeins. } \\ q q . & \text {.. } & \text { oviductus. }\end{array}$

7. Helix brevipes, with its shell.

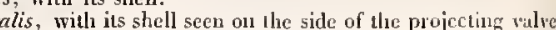
$a . b . c$. The projecting points of the flat or ventrid valve.
d. The dorsil valie.

ff. .. mantle coning aut from the interstice between the values, close to which are the branchia

$\begin{array}{ll}l . m . & \text {.. fins. } \\ \text { n. .. mouth. } & \text {. }\end{array}$

9. Parmacella Olivieri, Cus opened
$a$. The nrouth.
$b b$. . great horns.
$\begin{array}{lll}c . & \text {.. hrat horns. } \\ c . & \text {.. } \\ \text { salivary glands. }\end{array}$
t.. .. .. salivary glands.
g. .. bag for the colouriug
h. .. stomach.

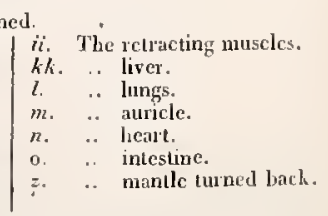
liver.
lungs.
learlt.
mantle turned back.

10. Calmar (Scpia Lotigo).

a. The head.

c. .. feet.

$\mid \begin{array}{lll}e . & \text { The funnel. } \\ f . & . . & \text { aldomen. } \\ g . & . . & \text { fins. }\end{array}$
11. Brin of the Polypus:

- The ring round the arson, did. The lateral gonghions.

phragus.
brain.

ce. .. optical ganglions

11.* Brain of the Aplysia.

a. The ring round the asoplagus.

blominal ganglion.

12. The animal and shell of the Hclico-Limax elongale

13. Janthirra peniceplata, with its vesicular appendage (spuma cartilaginea) attached to the posterior part of the foot.

1. Aplysia.

The head.

b. .. inferior tentacula.

c. .. superior

d. .. eyes.

.. .. inantle.

$f$. . operculum of the branchir.

15. The female Sigarclus seen underneath: the head and foot a litle bent to shew the entrance of the branchial eavity.

a. The notch.

$$
\text { | b. The anus. }
$$

16. The male Sigaretus seen underneatl
a. The notch.
bi. .. tentacula.
d. The anterior prat of the foot eleft
c. . foot.

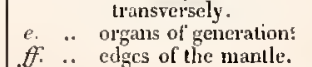

caninaris Meditarverea.

18. Plectophorus with its shell.

19. The female Viripara taken out of its shell.

a. The foot partly folded in two.

b. .. operculum iltached to the posterior part.

c. .. head with the tcut aenla and trunk.

c. litle siphon prolonged under the right tentaculun.

-. .. lateral membrane of the left side.

.. edge of the mantle.

A small portion of the branchiæs shering itself from underncath.

h. The orifice of the romb and anus.

20. Halyotis, drawn from the living aninal, with all its ornaments.

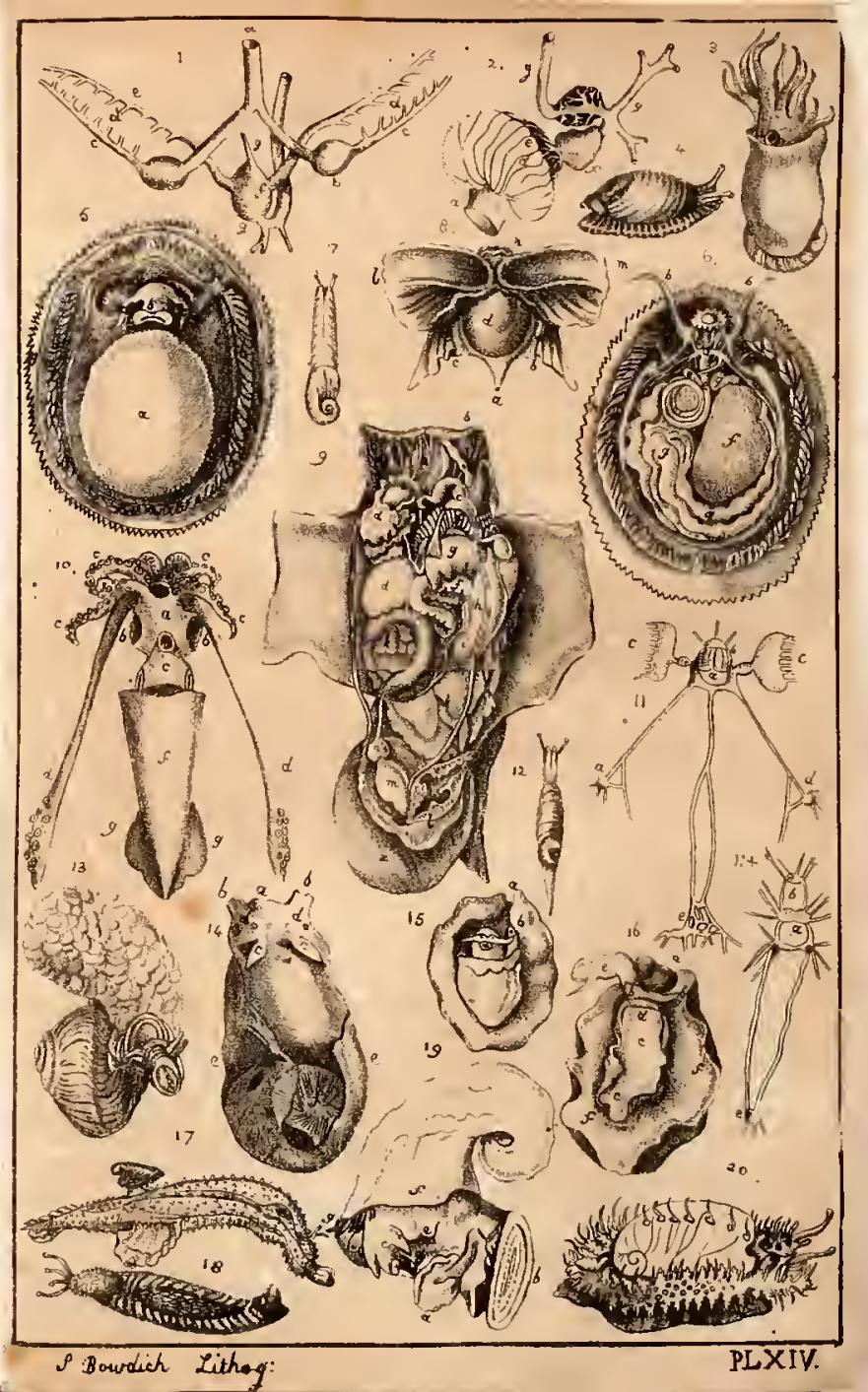





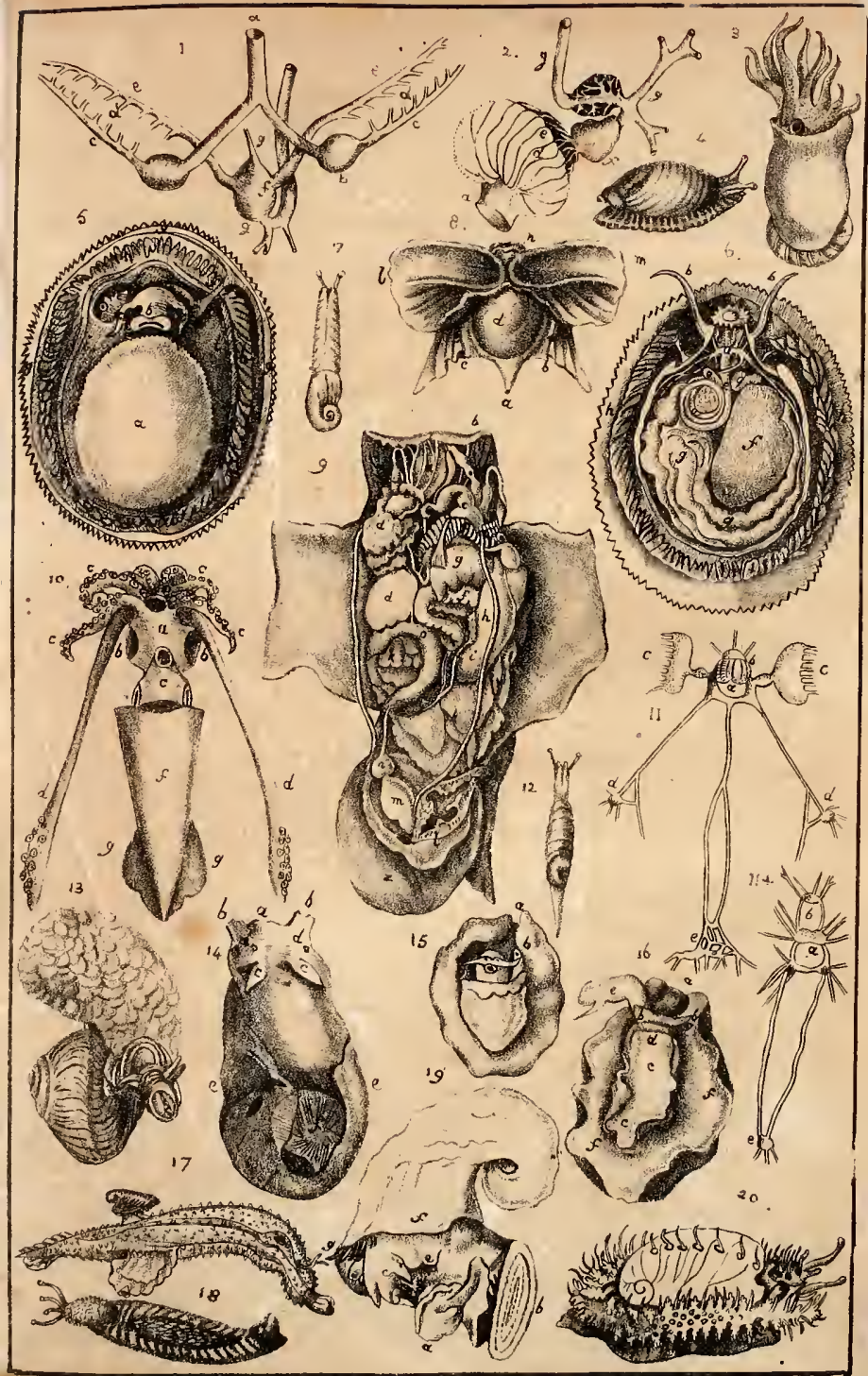

I Bourdich Lithog: 
1. The Argonauta argo sailing.

2. Ocythoë Cranchii, Leach, sitting within the shell.

3. Clio Borealis.

a. The body.

b. .. viscera seen through the common coverings.

$c c$. .. tubercles of the head, and the holes into which the three tenta. cula on each side retire.

dd. .. branchix and fins.

4. Pneumodermon, front view:

a. The body.

b. .. head.

c. .. mouth.

dd. .. lips.

e. The chin or pointed fleshy appen= dage.

$\mathscr{O}$. .. fins.

g. .. branchiæ.

h. .. trunk of the branchial vein.

5. Pneumodermon, with the skin divided to shew the position of the pericardium and fleshy tunic.

$i$. The auricle.

$k$. .. pericardium.

ll. .. fleshy tunic with its longitudinal fibres.

6. The Eolis, placed obliquely, shewing the belly and right side.

7. Scyllcea pelagica, on the right side.

$H H$. The under surface of the foot hollowed into a deep furrow, by which it suspends itself.

G. .. mouth.

$A A$. .. two tentacula.

$B C$. Two pair of mombranous flexible These and the back bear the wings.

D. A crest on the tail. branchix in the form of little fi-

$E$. The orifice of generation.

$r$. .. orifice of the anus. 
8. Scyllea pelagica secn on the side of the belly.

9. Scyllae pelagica suspended to a branch of the Fucus natans.

10. Phyllidia trilineata seen on the upper side.

$a a$. The indentations for the upper tentacula.

b. .. $\quad . . \quad$ of the anus.

11. An upper tentaculum magnified.

12. Phyllidia trilineata seen underneath.

aa. The inferior tentacula, between which is the mouth.

b. .. branchiæ of the left side.

c. .. orifice of generation.

13. A Limax seen on the right side, the tentacula half developed.

aa. The great tentacula.

bb. .. smaller ..

c. .. mouth, between which and the small tentacula are seen the papilla of the upper lip.

dd. .. foot

$e$. .. posterior point of the back, whence issues the mucosity by which it suspends itself.

f. .. mantle.

g. .. orifice for respiration.

h. .. .. generation. 

PLATE XY.

1. The Argonauta argo sailing

2. Ocylloë Cranchii, Leach, sitting within the shell.

3. Clio Dorealis.

The body

viscera seen through the common coterings.

. cula on each side retire.

dd. .. branchix and fins.

4. Pneunodermon, front view.
a. The body.
b. .. head.
c. dd. .. lips.

e. The chin or pointed leshy appen* di. dage.

g. .. branchise

5. Pneumodermon, with the skin divided to shew the position of the pertcardium and fleshy tunic.

i. The auricle.

h. .. perieardium.

ll. .. fleshy tumic with its longitudinal fibres.

6. The Eolis, placed obliquely, shewing the helly and xight side.

7. Scylleca pelagica, on the right side.

$H H$. The under surface of the foot hollowed into a deep furrow, by which it suspends itself

G. .. mouth

AA. .. two tentacula.

BC. Two pair of membranous flexible These and the back bear the

D. A erest on the tid.

$F$. The orifice of generation.

F. .. orifice of the anus.
Sollent pelagien seen on the side of the belly.

9. Scyllera pelagica suspended to a brancle of the Fucus natans.

10. Phyllidia trilincata seen on the upper side.

The indentations for the npper tentaeula.

f the anus.

11. An upper tentaculum magnified.

12. Phyllidia trilinea a seen underneatl.

The inferior tentaeula, hetween which is the moutl.

b. ., branchix of the left side.

c. " orifice of gencration.

A Limax seen on the right side, the tentacula half developed. an. The great tentaeula.

b. .. smaller

c. .. mouth, between which and the small tentacula are seen the papilla of the upper lip

dd. .. foot

e. posterior point of the back, flence issnes due mucosity hy which it suspends itself

f. ." mantle.

g. .. orifiec for respiration

h. ... gencration.

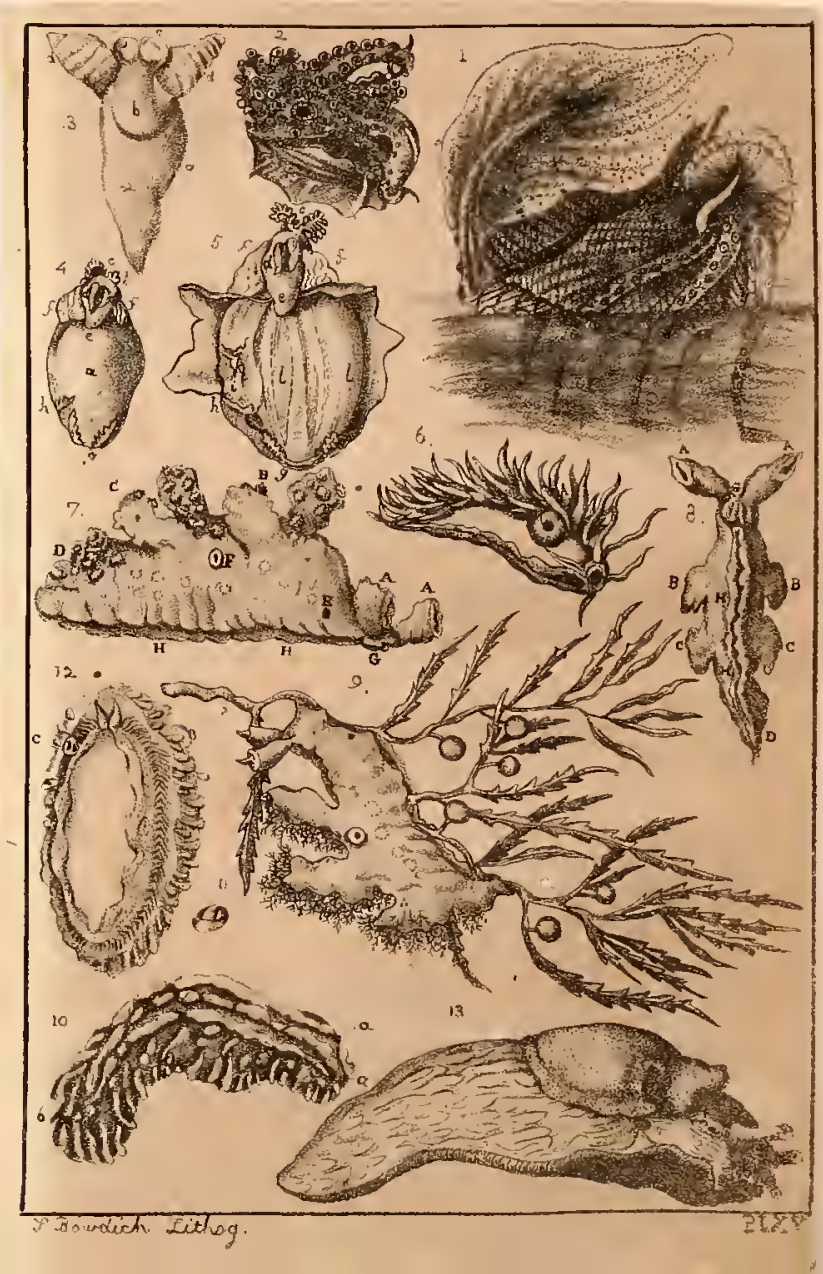





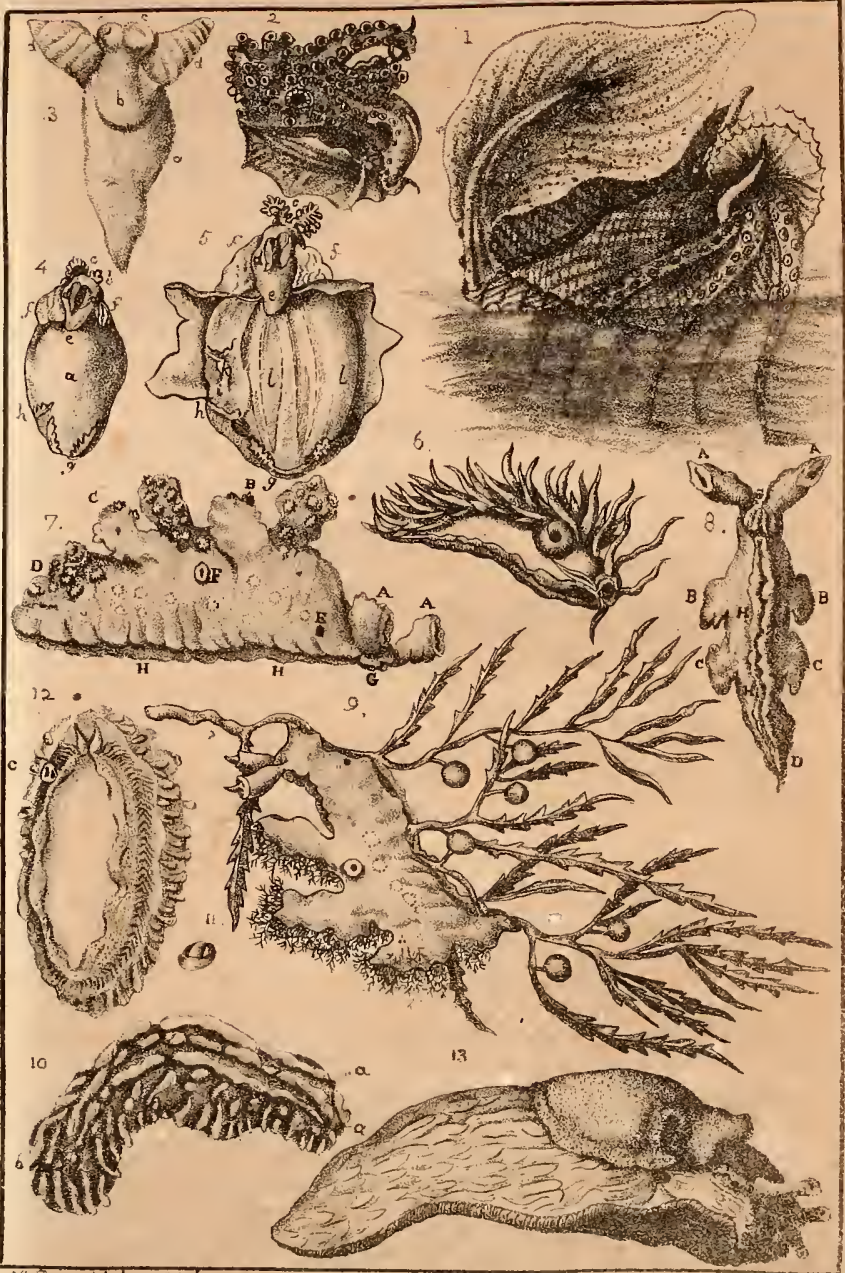

Towdich fitlog: 
1. Bulla aperta entire, seen on the back.

a. The fleshy plate which covers the front of the body, or the tentacular disk

c. .. part containing the shell.

2. Bulla aperta on the right side, with the ventral fleshy plate separated from the dorsal, to shew what is between them.

$a$. The tentacular disk.

b. .. plate serving as a foot. $f . \quad$.. $\quad$ common orifice of the male organ and oviductus.

3. Bulla aperta, seen underneath.

$b$. The plate serving as a foot.

c. .. part containing the shell.

d. A part of the branchix.

4. Bulla aperta, partly dissected.

$a$. The stomach.

b. .. oesophagus.

d. .. branchiæ.

$$
\begin{array}{|ccc}
e . & \text { The heart. } \\
f . & . . & \text { liver. } \\
g . & . . & \text { intestine. } \\
h . & . . & \text { testicle. }
\end{array}
$$

5. The tongue of the Bulla aperta greatly magnified.

6. Helix pomatia, taken from its shell, and seen on the left side : a large portion of the covering of the pulmonary cavity has been taken away to shew its position; also the teguments of the remainder of the spire, to shew the situation of the heart, the bag of viscous matter, etc.

a. The large right tentaculum half developed.

b. .. hole whence the left tentaculum issues.

c. .. hole for the small tentam culum of the same side.

dd. .. trro lobes of the veil or upper lip.

eee. .. edges of the foot.

$\mathscr{O}$. Two of the lobes placed under the collar.

gg. The pad of the collar.

hh. .. place where the covering of the pulmonary cavity has been cut atvay.

i. .. rectum k. The hole for respiration seen within the pulmonary cavity.

l. .. diaphragm.

$m n$. .. heart and auricle in their proper place in the open pericardium.

o. .. commencement of the great artery of the spire.

p. $\quad \because \quad$ bag of viscous matter.

$q$. .. first part of the intestine.

r. .. second part.

ss. .. lobes of the liver. 
7. Capulus, Mont. (Pateilla Hungarica, Lin.) detached from its shell, and seen on one side.

a. The foot.

b. A sort of ruff which this foot has in front.

c. The muscle which attaches the foot to the shell.

$d$. The trunk.

ee. .. tentacula.

$f$. .. liver and a part of the viscera, which occupy the bottom of the shell.

8. Onchidium, under view.

9. Parmacella, seen on the back: the shell has been taken away, and only its impression remains.

10. The horned Planorbis, with its shell.

11. The animal of the Cyproea.

12.

Conus.

13. Emarginula entire.

14. Nerrous system of the Fissurella.

15. Animal of the Crepidula, detached from its shell, seen above; the abdomen and branchial cavity in their natural position.

16. Shell of the Crepidula seen underneath.

$a$. Plate which retains the point of the abdomen.

17. Animal of the Crepidula, detached from its shell, and the upper parti-. tion of its branchial cavity turned back to shew the branchix.

18. Testacellus halyotideus, animal and shell. 

Capulus, Mont. (Patella Hungarica, Lin.) detached from its shell, and
seen on one side.

\begin{tabular}{l|l|l}
$a$. The foot. & $d$. The trunk. \\
b. A sort of ruff which this foot & $e e$.
\end{tabular}

f. liver and a part of the viscora The muscle which attaches
the foot to the shell.

1. Bulla aperta entire, seen on the back.

a. The flesly plate which corers the fiont of the hody, or the tentacular

part containing the shell

Bulla uperta on the right side, with the vential fleshy plate separatcd from the dorsal, to shew what is between them.

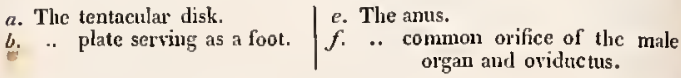

3. Bulla aperta, seen underneath.

b. The plate serving as a foot.

c. .. part containing the shell.

d. A part of the branchix.

4. Bulla aperta, partly dissected.
a. The stomach.
d. .. hranchie.
e. The heart.
g. .. intestine.

5. The tongue of the Bulla aperta greatly nagnified.

6. Helix pomatix, taken from its shell, and seen on the left side: a largc portion of the corering of the puhronary cavity has been taken away to shew the position; atso the peguncents of the resainder of the spits

$\begin{gathered}\text { a. The large right tentaculum } \\ \text { half developed. }\end{gathered} \mid \begin{array}{r}k \text { The hole for rcspiration seen } \\ \text { within the pulmonary ca. }\end{array}$

b. .. hole whence the left tentaculum issnes.

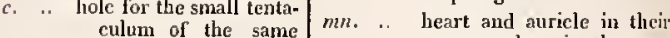
dd. . . tro lohes of the reil or upper lip.
edges of the foot.

ff. Two of the lohes placed un-

der the collar.

gig. The pad of the collar. ing of the pulmonary cavity has been cut iway.
8. Onchidium, under view.

9. Parnacella, seen on the back: the shell has been taken away, and only its impression remajns.

10. The horned Planorbis, with its shell.

11. The animal of the Cyprea.

12.

13. Emarginula entire.

14. Nerrous system of the Fissurella.

15. Animal of the Crepidula, detached from its shell, seen above; the abdomen

16. Shell of the Crepidula seen underneath.

a. Plate which retains the point of the abdomen.

17. Animal of the Crepidula, detached from its shell, and the upper part tion of its branchial carity turned back to shew the hranclipe

Testacellus halyotideus, animal and shell. proper place in the open
pericardium. artcry of the spire. bef viscous matis.

bis of viscous mattegr. first part of the intestin second part lobes of the liver

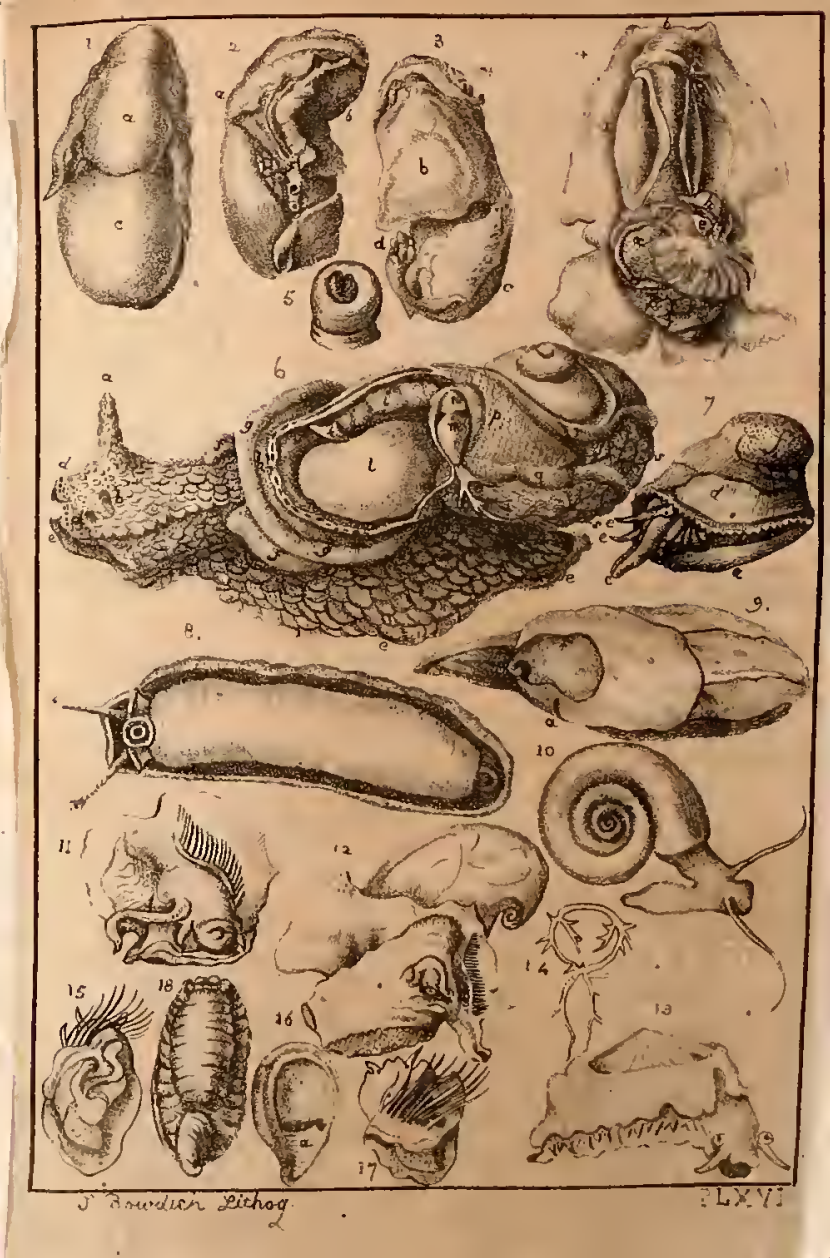





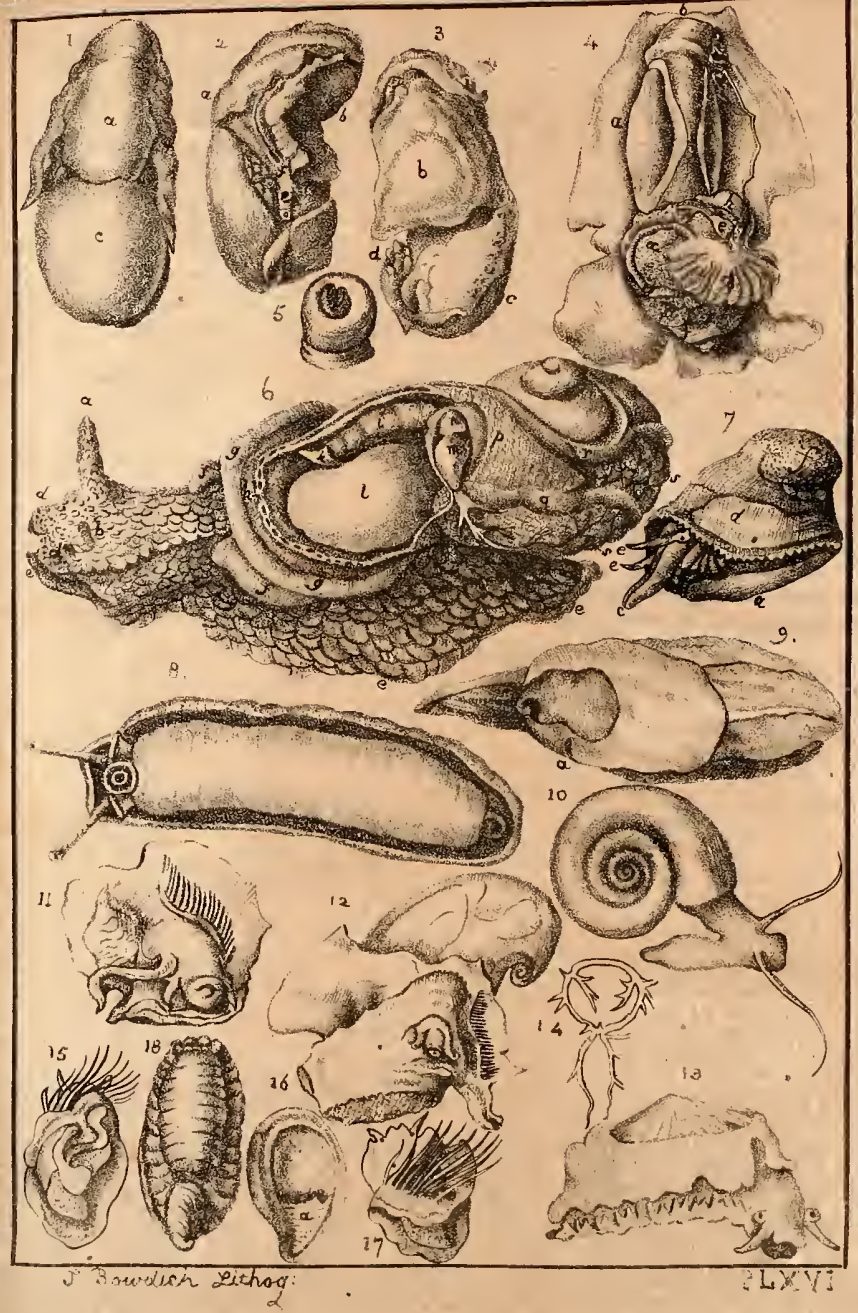




\section{PLATE XVII.}

1. Scalaria.

2. The female Vivipara taken out of its shell, and the branchial cavity opened.

a. The foot folded in two.

b. .. operculum attached to its posterior part.

c. .. head, with the tentacula and trunk.

d. .. little siphon prolonged under the right tentaculum.

e. .. lateral membrane of the left side.

$f$. .. edge of the mantle.

g. .. branchiæ.

$h$. .. womb swelled by the foetus within.

$h$. The orifice of the womb.

$h$. .. part situated under the spire.

i. .. anus.

$l$. .. canal of viscous matter.

$m$. .. projecting line, forming a semi-canal, which terminales at the siphon $d$.

n. .. heart and its auricle.

o. .. parts of the liver and intestine.

3. Trochus. (Cochlea sublivida, Lis.)

$h$. The head.

tt. .. tentacula.

ee. .. eyes.

4. Do. seen underneath

$f$. The foot.

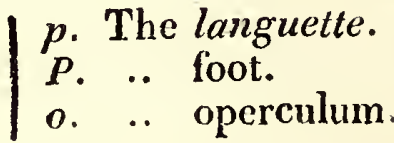

5. Animal of the Trochus pharonius, taken out of its shell, with its operculum.

6. 7. . . . . Turbo littoreus.

8.9.10... . Turbo chrysostomus.

11. . . . Nerita canrena, taken out of its shell.

12. .. . . Nerila ex uvia, with its operculum.

13. .. . . Trochus, Gualt. 
13. Trochus levis, List.
$h$. The head.
ee. .. eyes.
tt. .. tentacula.
p. .. male organ.
P. The foot.
f. .. filaments.
o. .. operculum.

14. Purpura.

$h$. The head.

ce. .. eyes.

tt. .. tentacula.

T. The trunk.

$\begin{array}{lll}\text { p. .. foot. } & \\ \text { o. } & & \\ & & \end{array}$

15. Buccinum undatum, half the natural size, seen on the left side; the trunk drawn in, and the male organ turned back, and hidden in the branchial cavity.
a. The male organ.
c. .. siphon.
dd. .. position of the branchiæ.
e. The position of the heart,
$f$. .. mucous plates placed to the right of the branchiæ.

16. Buccinum undatum, with the trunk and male organ extended,

a. The male organ.

b. .. trunk.

c. .. siphon.

17. Natica .. Fossar, Adan. magnified.

$h$. The head.

ee. .. eyes.

1l. .. fleshy appendages at the

$t t$. The tentacula.

o. .. operculum. base of each tentaculum.

18. Natica

$m$. The mouth,

$f$.. fool, 




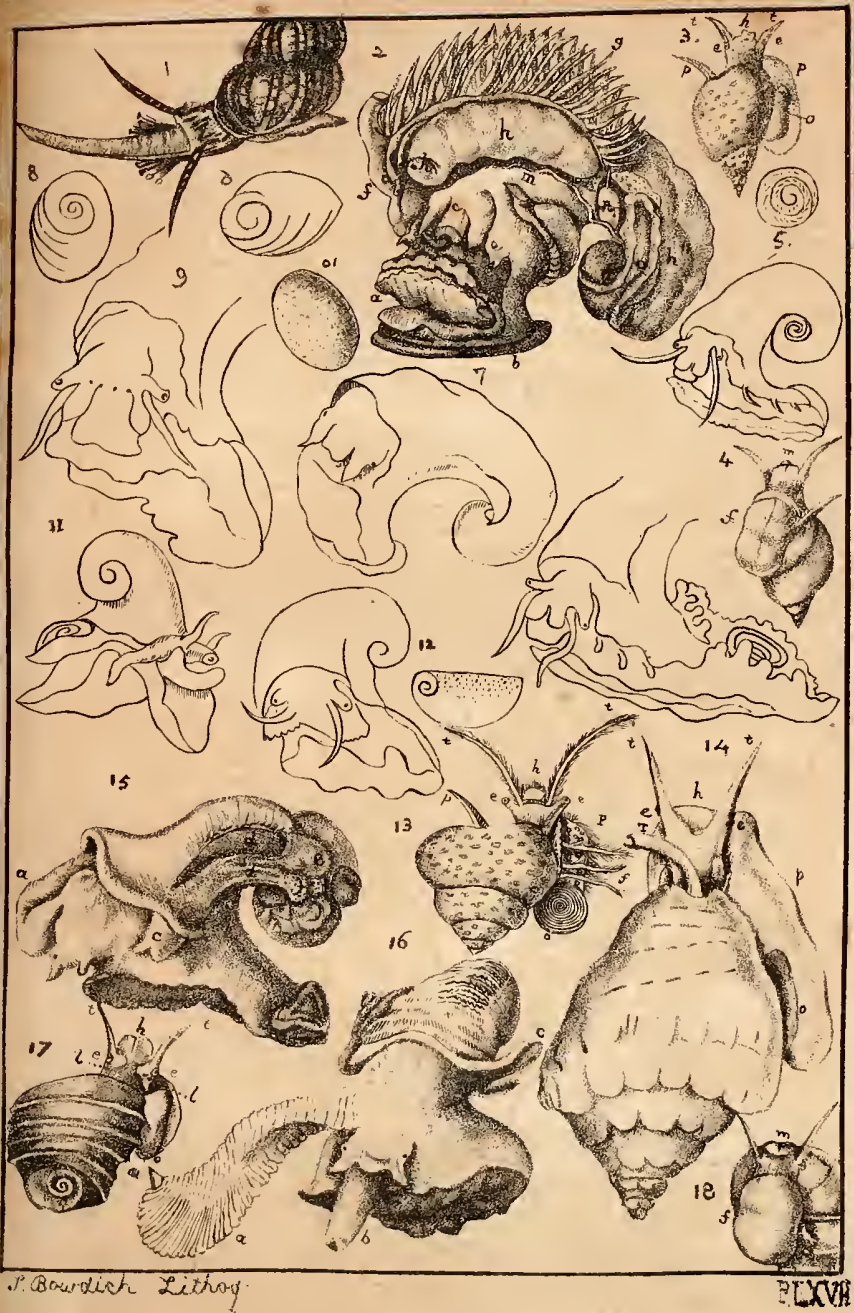





\section{PLATE XVIII.}

1. Voluta Ethiopica, 1-2.

2. Voluta.

3. Cerithium.

4. Aquila.

2. Fusus.

6. Murex decussatus.

7. Cassis glaucus. 




\section{PLATE XIX.}

1. Strombus pugilis.

2. Murex saxalilis.

3. Halyotis vulgaris, its shell taken away, seen on the back, and the edges of the branchial cavity put asunder.

A. The large muscle which attaches the animal to the shell.

a. The anus.

bb. .. branchix.

c. The viscous organ.

d. .. heart in its pericardium.

1. Halyotis, etc. the pericardium and branchial cavity opened.
$A$. The large muscles above.
$d$. The heart.
a. .. anus.
bb. .. branchiæ.
c. .. viscous organ.
e. .. right auricle.
f. .. left auricle.
$g$. .. heart surrounding the rectum.
ii. .. branchial arteries.

5. The heart and large vessels magnified.

$a$. $i$. As the preceding figurc.

h. The right branchial rein. 
6. Fissurella entire, covered with its shell, which is set in the cdges of its mantle.

7.

a. The disk of the foot.

bb. .. circular muscle which joins it to the shell, and which has been cut.

$b$. A portion of this muscle remaining with the mantle.

$c c$. The mantle thrown back, and seen on the under side.

d. .. hole with which it is pierced.

ee. .. branchiæ.

$f$. .. anus.

g. The heart.

hh. .. auricles.

ii. .. intestine.

$k$. .. cesophagus.

l. .. pharynx.

mm. .. salivary glands.

nn. .. lateral ganglions of the braiu.

o. .. extremity of the tongue.

pp. .. liver.

$q . \quad$.. ovarium.

8. Vermeíus, Adanson.
$c$. The tentacula.
$Y$. .. eyes.
P. .. foot.
$F$. Cylindrical filaments.
o. Operculum.
M. Mantle.
A. Aperture by which the animal breathes.

9. The same animal seen underneath.

$p$. The foot pul on one side, to make it more apparent.

$B$. The mouth. 

4i. Fissurella entire, covered with its 'shell, which is set in the edges of its

$$
\text { opcn. }
$$

\begin{tabular}{l|l|}
$a$. The disk of the foot. & $g$
\end{tabular} - jevalar muscle which th. .. auricles. joins it to the shell,
and which has been

l. A portion. rion of this muscle re- $l$ l. .. pharyne.

1. Shombus pugilis.

2. Murex saxalitis.

3. Halyotis vulgaris, its sletl taken away, secn on the back, and the edges

aninal to the shell. a. The anus. c. The viscous organ.
d. .. heart in its pericardium.

4. Halyotis, ete. the pericardium and branchial cavity opened.
A. The large muscles ubove.
d. The heart.
$e$. right auricle.
a. $b$... anus.
$\begin{array}{lll}\text { e. } & \text {.. right auricle } \\ f . & \text {.. } & \text { left auriclc. }\end{array}$
.. viscous organ.

5. The heart and lurge vesscts maguificd.

a. $i$. As the preceding figure.

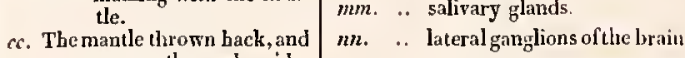

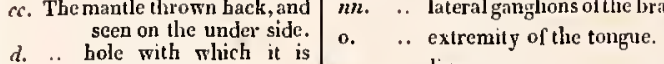

\begin{tabular}{ll|lll} 
& pierced. & $p p$. &.. & liver. \\
ee... & brinclize. & $\eta$ &.. & ovariu \\
f. & anus. & & &
\end{tabular}

8. Vermetus, Adanson

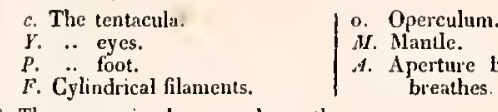

$\eta$. .. ovarium.

The same animal seen underneatls.

$p$. The foot put on one side, to make it more apparent.

$B$. The mouth.

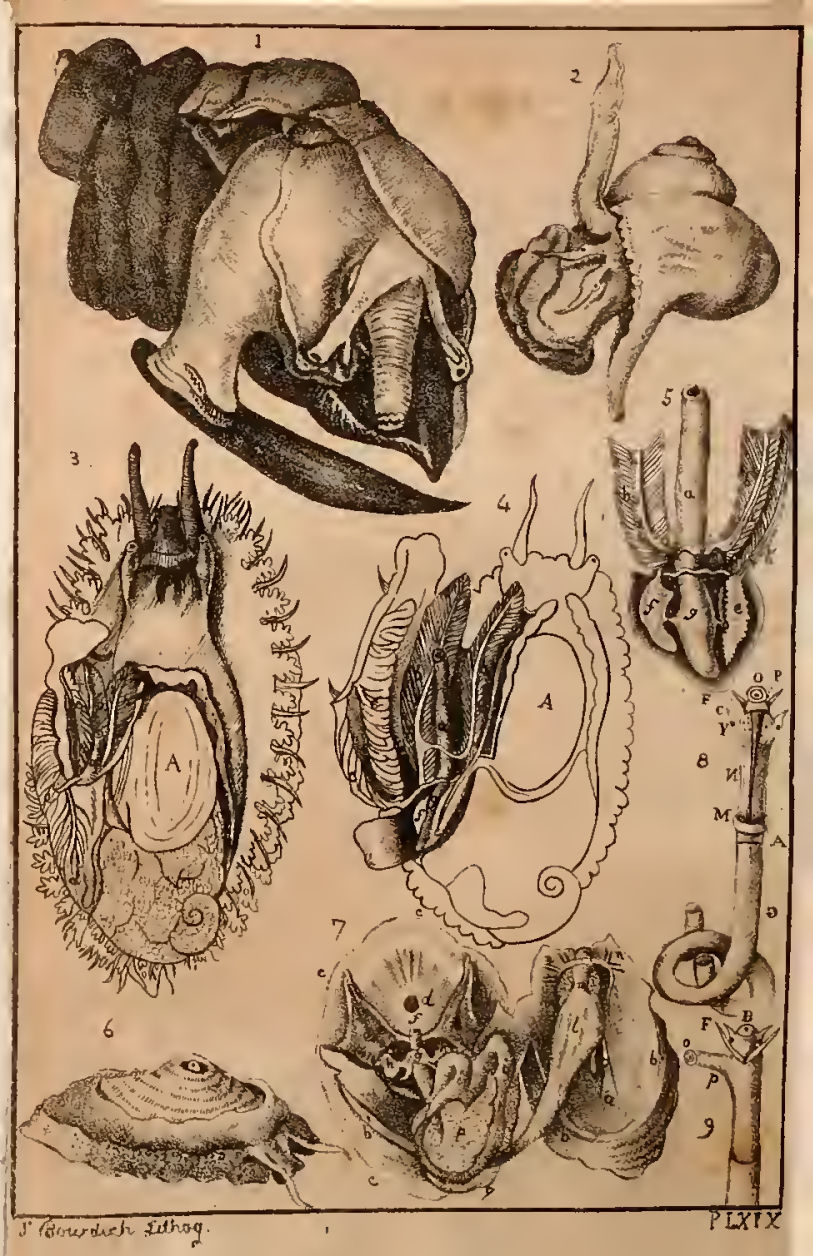








\section{ELEMENTS OF CONCHOLOGY,}

INGLUDING

\section{THE FOSSIL GENERA.}

$\circ$

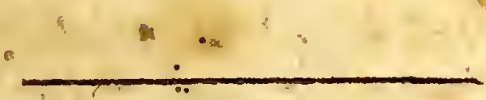

PART II. BIVALVES. MULTIVALVES. TUBICOL

\section{PARIS,}

\section{PIINTED BX J. SMITH,}

AND SOLD BY G. B. SOWERBY, 33, KING STREET, COVENT-GARDEN, AND I. STUTCUBURY, 3, DOVE COURT, OLD JEWRY, LONDON.

1822.

(Price Twenty Shillings.) 



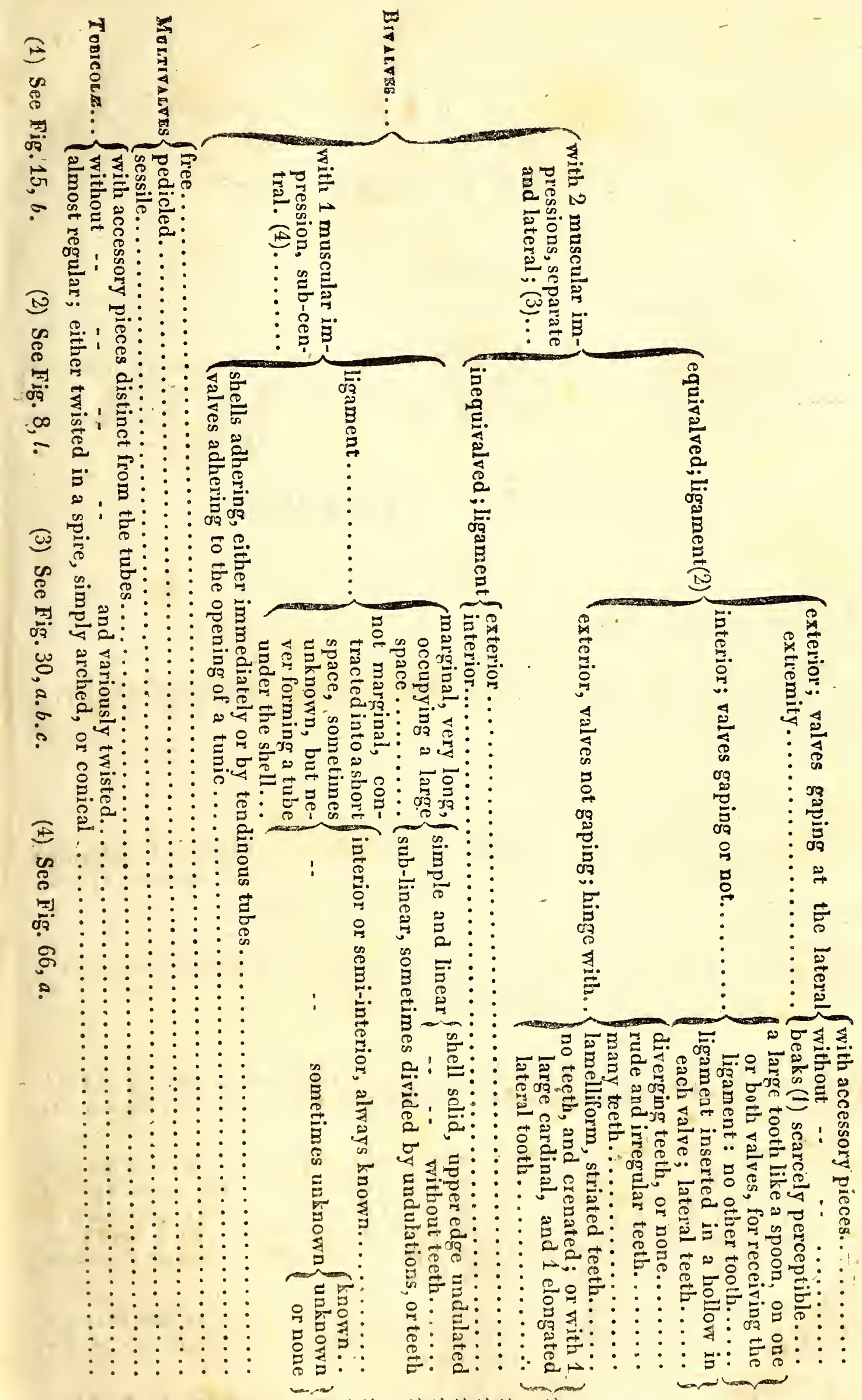

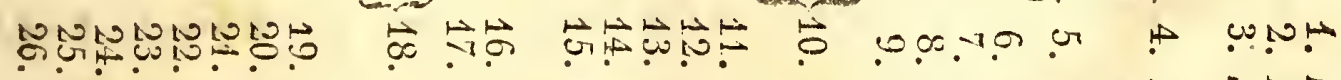

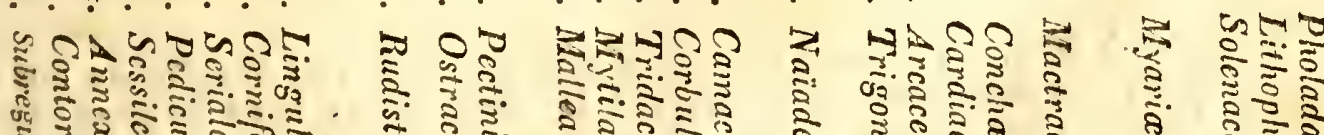

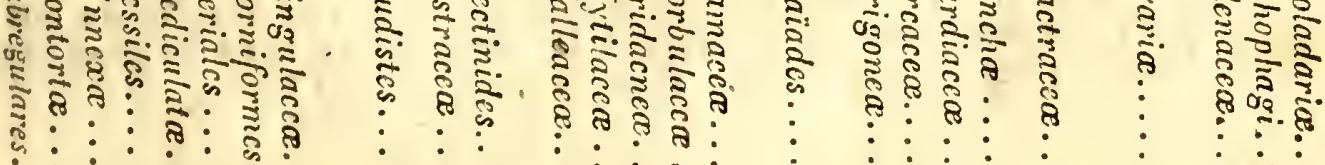

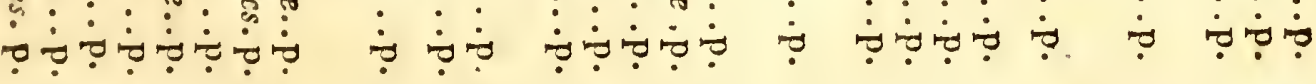

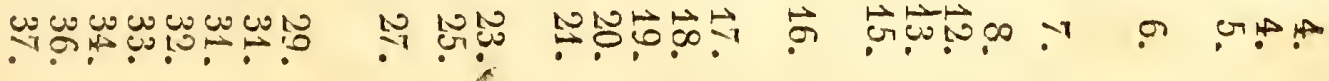




\section{DIVISION I. PHOLADARIE.}

GENERA. (1)

4. Pholas. Lin. $\mathbf{T}$.

Transverse, gaping at A plate from each Ligament exterio:, eachend; generally white valve, projecting into with accessory pieces and striated. Fig. 1. the other valve. distinct from the valves. (2)

\section{DIVISION II. LITHOPHAGI.}

\section{GENERA.}

1. Gastrochena, Spengler. T.

Gaping at both ends, but at one much more than the other : very fraHinge linear, mare Ligament exterior. gile. (3) Fig. 2.

\section{Byssomia. Cuv. M.}

Oblong, opening opposite'to the beaks. Fig. 43.

Hinge without teeth.

3. Petricola. Lam. M.

Sublrigonal, inequilateral; one end rounded, the other gaping. Fig. 5 .
Hinge with 2 teeth on one valve, and 1 on the other, or 2 on each. (5)
Ligament exterior : with a byssus. (4)

Ligament exterior.

(1) Where the habitat is not mentioned, the genus is found in the seas and different clinıtes of both hemispheres : T. indicates that it is terrestrial; M. marine; F. fiuviatic.

(2) Some of these accessory piecrs are attached to the hinge, and cover the liga. ment exteriorly; olhers are willin, fixed under the beaks. The animals pierce stone or wood, or bury theneselve's in the sand; they are generally stationary in the holes which they have bored, and the shrll is very fragile. They have been much sought for on account of their agreeable flavour; some species are found on the coasts of France. Foss. in Cragr Marl, London Clay.

(3) They pierce and live within madrepores. The animals of this Division bury themselves, with their anterior extremity always near the mouth of the hole which contains them, ready to receive the water.

(4) One species is very abundant in the Northern Seas, and is provided with a byssus.

(5) Lamarck formerly divided this genus into Petricola and Rupellaria; but the variations he has subsequently discovered in their hinges, have induced him to reunite them. They inhabit stones, Foss. in Italy, at Pont Levois. 
4. Saxicava Bellevue. M.

Transverse, inequilatesal, gaping at the upper part. Fig. 3.

\section{Venerirupis. (Vene-} RUPIS. Lam.) M.

Inequilateral, gaping at one end. Fig. 4.
Hinge with only 2 Ligament exterior. dentiform tuberosities, wide apart.
Hinge with 2 teeth on one valve, and 3 on the other, or 3 on each, small, near together, and parallel.
Ligament exterior.

\section{DIVISION III. SOLENACEÆ:}

\section{GENERA.}

1. Solen. Lin. M.

Equivalved, transversc-

Hinge lateral, with 2 or 3 little teeth, joining each other laterally curved. Beaks very small, when shut.

ly elongated; gaping at each end, sometimes a little not projecting. Fig. 6 .

a. Cardinal teeth contiguous to the anterior edge.

R. . . . . distant from $\quad$. $\quad$..

$\gamma$. . $\quad$. nearly in the middle. (1)

\section{SANGUinolaria. Lam.M.}

Sub-elliptic, gaping a little at the lateral extremities, upper edge arched. 2 contiguous cardinal teeth on each valve.

Ligament exterios . Fig. 8.

3. Giycineris. Lam. M.

Shell gaping widely on each side : the second edges ${ }^{*}$ (interior and cal- teeth.

Hinge callous, no

Ligament exterior.(2) lous) projecting without. Fig. 7 .

(1) They live in the sand on the sea-shore, and bury themselves even two feet below the surface, in a vertical position; cunsequently, when the animal is living, the shell is always placed perpendicularly on one of its sides, the gaping part uppermost for the passage of its tubes. Its movements are confined to leaving the bottom of itshole, coming to the surface, and re-entering by means of the extensions and contractions of its muscular foot, which is at the lowest end of the shell. Foss. at Grignon, Bourdeaux, Ilaly, and in the London Clay. Clay.

(2) Jamaica, New Holland, American and Indian Seas. Foss, in the London

- Apud Gallos, Nymphoc. v. Fig. 30. a.

(3) Northern Seas. Foss. at Grignon. 
4. PANOPAA. Merard. M.

Equivalved, transverse, unequally gaping at the sides. Fig. 9 .

5. Psammobia. Lam. N.

Oblong-oval, rather fiat, a little gaping on each side. Beaks more projecting. Fig. 10 .

6. Psamotea. Lam. M.

Oblong-oval, a little gaping at the sides. Beaks more projecting. 'The inner, callous, edges projecting a little. (2) Fig. 11 .
One conical cardinal tooth on each valve, and a compressed callosity at the side, not project- losities. (1) ing without.

Hinge with 2 teeth on one valve, and 1 on the opposite valve, entering between the other two when clossed.

- 1 cardinal tooth on each valve, or on one valve only.
Ligament exterior, on the longest side of the shell; fixed on the callosities. (1)

\section{Ligament exterior.}

Ligament exterior, attached to the inner, callous, edges.

\section{DIVISION IV. MYARIE.}

\section{GENERA.}

1. Mra. Lin. M.

Shell gaping at each end. Fig. 12.

A large compressed, rounded, cardinal tooth, projecting almost vertically, and hollowed like a spoon. A cardinal hollow on the other.

\section{Amatina. Lam. M.}

Sub-equivalved, gaping at both ends, or at one only. Fig. 13.
A tooth like that of the Mya on each valve, the teeth supported either by a rib or a plate running obliquely into the shell, and frequently a decurrent fissure giving the appearance of a secon I plate.
Ligament interior, inserted on the tooth and in the hollow. (3)
Ligament interior, attached to each tooth.

(1) Mediterranean. Foss at Parma. The species found at the foot of the Appenines is in such good preservation that it appears as if just taken from the sea.

(2) Lamarck supposes this genus to be composed of degenerated Psammobia, Foss. at Grignon.

(3) Foss, in the London Clay, Crag Mart, Woolwich Loam, and Green Sard, Fuller's-earth Rock. 
 \\ DIVISION V. MACTRACEE.}

GENERA.

1. Lutraria Lam. M.

Inequilateral ; gaping at the lateral extremities. Fig. 14.

Hinge either with 1 tooth folded in two, or 2 teeth, one of which is simple, with a deltoid hollow close to it : no lateral teeth.

a. Shell transversely oblong.

f. .. orbicular or sub-trigonal.

2. Mactra. Gmel. M.

Inequilateral, subtrigonal; a little gaping at the sides : beaks protuberant. Fig. 15.

3. Crassatella. Lam. M.

Inequilateral, suborbicular, valves close.Fig.16.

\section{Unguirina. Daud.}

Shell transverse, rounded above, almost equilateral: valves close, furrowed. Fig, 19.
1 compressed cardinal tooth, folded in a serted in the cardinal furrow on each valve, hollow. (2) with a hollow close to it ; or 2 lateral compressed teeth.

2 sub-diverging cardinal teeth, with a hollow at the side: lateral teeth none, or obscure.
Ligament interior. fixed in the cardinal hollows. (1) 
6. Solenimya. (Solemya.

Lam.) M.

Inequilateral, equivalved, obtuse at the extremities; a shining epidermis, projecting beyond the shell; beaks scarcely perceptible, a little gaping on one side. Fig. 17.

\section{Amphidesma. Lam. M.}

Inequilatefal, sub-oval or rounded, sometimes a little gaping at the sides. Fig. 18 .

Hinge with 1 or 2 teeth and a narrow hollow for the inner ligament; sometimes with lows. (2) lateral teeth.

\section{DIVISION VI. CONCHE.}

\section{GENERA.}

1. Megades ma. Potamophila Sowverby. Galatea. Lam. F.

Equivalved, sub-trigonal, covered with a greenish epidermis : inner edges prominent. Fig. 21.

\section{Cyclas. Lam. F.}

Equivalved, ventricose, oval, beaks protuberant, very fragile. Colour generally grey or greenish. Fig. 22.

\section{2 furrowed cardinal} teeth, approaching at base on one valve, 3 on the other, the middle projecting and separated, lateral teeth wide apart.

Cardinal teeth very small, sometimes scarcem ly any, sometimes 2 on each valve, one of which is folded in two; sometimes only 1 (folded or lobed) on the one valve, and 2 on the other. Lateral teeih transversely elongated, compressed, lamelliform.
Ligament exterior. (4)

(1) This ligament is pressed between the tooth and edge of each valve, and shows itself without, enveloping the edge.

(2) This genus forms a link from the Mactracex to the Dimyarix, with an exterior ligament.

(3) The only species known, comes from Ceylon and the East-Indies. Mr. Sowerby has lately substituted the name of Potamophila, because that of Galatea had already been applied by Fabricius to a $C_{r a b}$; but, unfortunately, Latreille, had establisbed a genus of Crustacea, under the name of Potamophila, upwards of five years ago. V. Regne animal, tome $3, \mathrm{p} .18$. I have therefore presumed to propose the name of Megadesma ( $\mu \varepsilon \gamma$ a great, $\delta \varepsilon \sigma \mu o s$ a ligament). The name of Galalea, being that of a Sca. Nymph, was, morcover, by no means well chosen for a Fluviatic shell.

(4) The exotic Cyclas becomes very large, especially that from Asia. Foss. in Crag Marl at Bctz; the species found at Bctz, resembles the exotic Cyclades more than these of Europe. 
3. Cyrena. Lam. F. Rounded, triangular, 3 teeth on each valve
swelled or ventricose, so- generally two latera lid, inequilateral; with an teeth, one of which is epidermis, but the beaks often close to the carnaked. Fig. 23. dinal teeth.

a. Lateral teeth dentated.

f. .. .. entire.

4. Cipsai Lam. M.

Equivalved. Fig. 24.

2 cardinal teeth on the right valve, 1 bifid entering tooth on the

Ligament exterior, on the shortest side. (2) other. No lateral teeth.

5. Loripes. Poli. M.

Lenticular. (3) Fig. 37. Cardinal teeth almost effaced.

Ligament exterior, in a simple furrow. Besides the usual impression, a line from that of the anterior muscle towards the beaks.

6. Lucina. Brug. M.

Sub-orbicular, inequi-

2 diverging cardinal lateral; beaks small, point- teeth, 1 bifid, all varyed, oblique. Fig. 25. ing or disappearing -with age; 2 lateral teeth (1 close to the cardinal) or none.

Ligament exterior, the muscular impressions (one of which is prolonged into a streak) very wide apart. (4)

7. Conbis. Cuv. M.

Equivalved, without 2 cardinal and 2 latefold or anterior edge, ral teeth. beaks curved within, opposed. Fig. 26.

Ligament exterior, muscular impressions simple. (5)

(1) There are none found in Europe. Fluviatic and Marine Conchæ differ not only in habitation, but in lateral teeth.

(2) From Brazil and the Indian Ocean.

(3) Lamarck only sees a specific difference in these shells, adopted as a genus by Poli and Cuvier.

(4) Foss. Grignon, environs of Paris, Chaumont, Longjumeau.

(5) Indian Ocean. The fossil species of this genus are very nat. Foss. at Grignon, Marl-pits of Granvillc. 
8. Tellina. Lin. M.

Orbicular, generally 1 or 2 cardinal teeth flattish, anterior side angu- on the same valve: 2 the shortest side. (1) lar, presenting an undulat- lateral teeth. ing irregular fold. Fig. 31 .

a. Shell transversely oblong.

f. .. orbicular or a rounded oval.

9. Tellinomes. Lam. M.

Inequilateral, fiattish, 2 diverging cardinal slightly gaping at the sides, teeth on each valve: 2 beaks small, not swelled, lateral teeth, almost efwithout fold. Fig. 36. faced on one valve, 1 - of

Ligament exterior. them very near the cardinals.

10. Donax. Lin. L. M.

Equivalved, inequilateral, anterior side very short, and very obtuse. Fig. 27.

2 cardinal tecth, either on each valve or on
one only, 1 or 2 lateral

Ligament exterior, short. (2)

teeth.

a. Internal edge of the valves entire.

r. . . . . $\quad \ldots \quad$. . distinctly crenated or dentated.

11. Cytherea. Lam. M. 4 cardinal teeth on

Equivalved, inequila- the right valve (4), 3 of teral, sub-orbicular, tri- which are diverging, gonal. Fig. 28. but near together at

Ligament exterior.(3) the base; and 1 (isolated under the 3 diverging cardinal teeth) on the other valve, which has a hollow parallel to the edge: no lateral teeth.

a. Internal edge of valves entire.

Anterior cardinal tooth with a striated channel or a dentated
edge. Anterior cardinal tooth neither channelled nor dentated.

b. Internal edge of valves crenated or dentated.

(1) Austral Ocean. They are frequently found at a small depth in the sand on the sea-shore. Foss. in Crag Marl; at Grignon, Parnes, Dax, Bourdeaux, Environs of Troyes.

(2) These are also found in the sands of the sea-shore. Foss. at Parnes, Beynes, Houdan, Grignon.

(3) Foss. at Bourdcaux, Mont-Marius, Turin, Beauvais, Grignon, Courtagnon, Houdan, Pontchartrain.

(4) The valve on the right hand, when you hold the shell with its hinges downwards, and the side with the ligament farthest from you. 
12. Venus, Lin. M.

Equivalved, inequilateral, suborbicular. Fig. 29 and 30.

3 cardinal teeth close together on each valve, lateral teeth diverging at the summit.

\section{a. Internal edge of valves cremated or den- Strix scaly. tated.}

๖. Internal edge of valves entire.

13. VENERICARDiA. Lam.

\section{Foss.}

Equivalved, inequilateral, sub-orbicular, with longitudinal radiating ribs. same side.

Fig. 32.

\section{Crassina. Lam. M.}

\section{Astarte. Sowerby.}

Sub-orbicular, equivalved, sub-inequilateral, close. Fig 34,35 .

\section{Cyprina. Lam. M.}

Equivalved, inequilateral, like an oblique heart; beaks obliquely curved. Fig. 33.
Hinge with 2 sirong diverging teeth on the right valve, and 2 very unequal on the other valve.

3 unequal cardinal teeth, close together at their base, a little diverging at the top: 1 lateral tooth, distant from the hinge, on the beaks by a hollow. (4) anterior side, sometimes obscure.
Ligament exterior, on the longest side; generally a third muscular impiession, very small. (3)

Ligament extcrior, partly sunk under tho beaks : callosities of the inner edge large, arched, terminated near the

(1) There are a few species which have their teeth almost straight; they generally live in the sand at a moderate distance from the water's edge; they are more numerous and varied in warm climates. Foss. in Crag Marl, Green Sand, London Clay; at Grignon, Pontcharlain.

(2) Foss. in the London Clay, at Grignon, Beauvais, Courtannon, Cambray, l'Oise, Essanville, Italy, Piedmont, Angers, Paris, Marl pits of Touraine, Chaumont.

(3) Foss. Crag Marl, Portland-rock, Oak.tree Clay, Under Oólile.

(4) By their lateral tooth (sometimes obscure) and their persisting epidermis, the Cyprince approach the fluviatic Conchce, and it is probable that many live in the sea, at the mouths of rivers. Foss. at Sicnna, Turin, Italy, Bourdeaux, England, Piedmont. 


\title{
DIVISION VII. CARDIACEÆE.
}

\author{
GENERA.
}

1. Cardium. Lin.

Equivalved, sub-cordi- 4 cardinal teeth on form, beaks protuberant, each valve, close togevalves dentated or folded ther, oblique, joining in on their internal edge; a cross with the correslongitudinal ribs, often pouding teeth : 2 lateral

Ligament exterior, very short : muscular impressions not very ap. parent. (1) thorny or scaly. Fig. 38 . teeth, wide apart.

a. No peculiar angle on the beaks; the anterior side at least as large as the posterior.

f. Beaks keeled or with an angle; the posterior side often larger than the anterior.

2. Isochrdia. Lam. M.

Equivalved, cordiform, ventricose; beaks wide in a spire. Fig. 39.

2 flattened cardinal teeth, one of which curves and enters under the beak: 1 elongated lateral tooth.

3. Hiatella. Daud. M.

Equivalved, very inequilateral, gaping at the upper edge. Fig; 40.
1 small cardiual tooth on the right valve, and 2 oblique teeth a little larger on the left valve.
Ligament exterior, forked on one side.

Ligament exterior.(2)

\section{Cypricardia. Lam. M.}

Equivalved, inequilateral, obliquely elongated. the beaks : 1 lateral Fig. 42.

3 cardinal teeth under tooth.

\section{Ligament exterior.(3)}

(1) They are found in all seas. Amongst the fossil Cardia of Europe, species may be recognized which now live in the Asiatic Ocean. They bury themselves in the sands of the coasts. Foss. in London Clay, Cragr Marl, Woolwich Loam and Green Sand, Limestone Rock, Derbyshire Peak Rock, at Grignon, Bourdeaux, Plaisance, Touraine, Sienna, St. Jean d'Assé, Chauffour, Ban, Paris, Pontchartrain, Montfort-Lomori, Cherbourg. The fossil species Cardium Hibernicum, is so singular in form, that notwithstanding its affinity to the Cardia in other respects, M. Lamarck thinks, were its hinge known, it would form a distinct genus. Seas.

(2) This shell is generally found amongst the fucus in the sand of the Northern

(3) New-Holland, Coast of Guinea, St. Domingo. Foss, Italy, Caen, Moutiers. 
5. Cardita. Brug. M.

Equivalved, regular, in= equilateral. Fig. 41.

2 unequal cardinal

Ligament exterior.(1) teeth, one short and. straight under the beaks, the other oblique and marginal.

a. Shell sub-cordiform or oval, more transverse than longitudinal.

ß. .. more longitudinal than transverse.

\section{DIVISION VIII. ARCACEIE.}

\section{GENERA.}

1. Cucul.lea, Lam. M.

Equivalved, inequilateral, trapeziform, ventricose; beaks wide apart, separated by the area of the ligament. Fig, 47.

Hingelinear, straight, Ligament exterior : with little transverse muscular impression teeth; the extremities forming a projecting anwith from 2 to 5 ribs. gular edge.

2. Arca. Lin. M.

Sub-equivalved, inequi- Hinge in a straight Ligament exterior.(3) lateral; beaks wide apart, line, with numerous paseparated by the area of rallel teeth; no ribs to the ligament: shell fre- the sides. quently gaping. Fig. 44.

๙. Upper edge not crenated within.

B. ... .. crenated within.

(1) The exterior side is very long, and the posterior very short : some are said to attach themselves to marine bodies by threads, like the Mytili and Arca. Foss. in Great Oôlite, Green Sund, Kelloway Stone, Bedford Limestone, Under Oôlite, Blue Lias, at Grignon, Touraine, Sienna, Angers.

(2) The greater number of the Arcacca live under the sand, at a little distance from the water's edge. The fossil species of the Cuculloca prove that it thickens as it grows older, and the lateral ribs of the hinge are proportionally more nu. merous; the area of the ligament also enlarges and acquires more furrows. Foss. in Grcen $S$ and, at Bcauvais.

(3) Several Arca are covered with a scaly or hairy epidermis, and some have one valve larger than the other at the upper edge. One species is found at Timor in a semi-fossil state. Foss. in Chalk Marl, Grecn Sand; at Houdan, Marl pits of Touraine, Bourdeaux, Grignon, Parnes, Angers, Paris, Plaisance, Turin. 
3. Pectunculus. Lam. M.

Orbicular, almost lenticular, equivalved, subequilateral, close: beaks apart, with an area for the scure or none.

Hinge arched, with numerous serial oblique Ligament exterior.(1) ligament. Fig. 45.

a. Furrows longitudinal, distant, with fine strix, either longitudinal or transverse.

$\beta$. Furrows longitudinal, projecting and radiating, with or without transverse strix.

4. Nucula. Lam. M.

Oval, trigonal or ob- Hinge in a broken Ligament marginal, long, equivalved, inequi- line, multi-dentated, in- partly interior, inserted lateral; beaks contiguous, terrupted in the middle in the hollow or spoon. without an area. Fig. 46. by a hollow or a little oblique projecting spoon; teeth oftcn advancing and pectiniform.

(1) Several species become very thick with age, and frequently change their form, which makes them difficult to recognise; they are generally found in mud. Foss. in London Clay, Woolwich Loam and Green Sand; at Grignon, Courtagnon, Bcauvais, Bourdeaux, Dax, Picdmont, Sicnna, Cassel, Pontchartrain, Soucurs, Plaisance, Mans, Touraine.

(2) Foss, in London Clay, Crag Marl, Chalk Marl, at Grignon, Courtagnon, Parnes, Bourdeaux, Bourgogne, Plaisance, Mont-Marius. 


\title{
(15)
}

DIVISION IX. TRIGONEZ.

\author{
GENERA.
}

1. Thigonia. Brug. M.

Equivalved, inequilate- Cardinal teeth oblong, Ligament exterior, ral, trigonal, sometimes flattened on the sides, marginal. (1)

sub-orbicular. Fig. 48. diverging and furrowed transversely; the 2 on the right valve furrowed on each side, and the 4 on the other valve furrowed on one side only.

2. Castalia. Lam. F.

Equivalved, inequilateral, trigonal; beaks naked, curved back.

Hinge with 2 lamelliform teeth, transversely striated; one posterior, distant, shortened, subtrilamellate; the other, anterior, elongated, lateral.
Ligament exterior.(2)

(1) The only living species was found by Peron at King's Island, New-Holland. It is covered with mother of pearl within; is a shell of singular beauty, and valued at a high price. Foss. in Crag Marl, Green Sand, Upper Oôlite, Under Oölite; at Puy-de-Dôme, Mans, Coulaines, Courtagnon, Gundershofen, Havre, Caen.

(2) This shell seems to form a link between the Trigonia and Naïades; it is imperfectly known from there being but one of the kind, in the Cabinet of $M$. le Marquis de Dree, which is not at present accessible. Habitat unknown. 


\section{DIVISION $\mathrm{X}$. NAIADES.}

\section{Unio. Brug. F.}

\section{GENERA.}

Equivalved, inequila- 2 teeth on each valve ; teral ; beaks naked, worn : one cardinal, short, irreepidermis greenish or gular, simple or divided brown; sometimes a little in two, sub-striated; gaping. Fig. $55 . \quad$ the other elongated, compressed, lateral.

a. Cardinal tooth short, thick, neither crested nor sub-striated.

6. .. . . . compressed, projecting, and frequently crested.

2. Hyria. Lam. F.

Equivalved, obliquely trigonal, auriculated, base truncated and straight.

Fig. 54.

3. Axodon. Brug. F.

Equivalved, inequilateral, beaks naked. Fig. 53 .
Hinge with 2 creeping teeth; 1 cardinal, divided into numerous diverging parts, the interior the smallest; the other lateral, very long, and lamellar.

Hinge linear; no tooth; a cardinal plate, smooth, truncated or forming a sinus at the anterior cxtremity, terminating the base of the shell.
Ligament exterior, posterior, muscular impression composite. (1)
Ligament exterior, linear. (2)

Ligament exterior, linęar, entering at one end into the sinus of the cardinal plate; muscular impressions wide apart, sub-geminate.(3)

a. No distinct angle at the posterior extremity of the cardinal line.

B. $\Lambda$

4. Iridina. Lam. F.

Equivalved, inequilateral; beaks small almost Fig. 52 .

Hinge long, linear, lessened in the middle, tuberculous, almost subcrenated; tubercles numerous and unequal.

(1) These shells exist in the rivers of Europe and both Indies; they are buried in the mud, with their beaks downwards : many of them furnish good pearls. Foss. in Gravel, Alluvial Clay, Sand, Coal-shale, Crag Marl, Portland Rock, Blue Lias, Yellow Limestone. The plate should be turned to view the figure of the Unio. Having received a better specimen after the first was engraved, I could only enlarge the characters to give them more force, which I fear has produced confusion, by making the figure too large for the space it occupies in the plate. The lower part of the valve Fig. 55, fits into the upper part of the valve, Fig. $55 a$.

(2) The habitat is unknown.

(3) They live in fresh-water lakes and ponds, under the mud at the bottom; they are not eaten on account of their insipid taste. There is a genus of serpents named Anodon 'v. Diclionaire des Scienccs Naturellcs), but as the shell appears to have the prior claim, I have not altered the name but merely corrected it, the French Conchologists having, unaccountably, written it in the accusative Anodonta.

(4) It lives in the rivers of warm climates, and when it is deprived of its epidermis, both the inner and outer surfaces present a beautiful appearance, the mother of pearl being of a reddish bue and reflecting the colors of the rainbow. 


\section{DIVISION XI. CAMACE无.}

GENERA.

\section{Diceras. (1) Lam.}

Inequivalved, adherent; beaks large, diverging, conical, turned in irregular spires. Fig. 56.

1 very large, thick, concave, sub-auricular tooth, projecting into the largest valve.

2. Chama. Lin. M.

Irregular, inequivalved, 1 thick, oblique, subadherent ; beaks curved, unequal. Fig. 60.

crenated tooth, fitting deeply inserted. (2) into a hollow on the opposite valve.

a. Beaks turning from left to right.

f. .. : : .. right to left.

3. Etheria. Lam. M.

Irregular, inequivalved, No tooth; hinges unadherent; beaks short, as dulated, sub-sinuated, if sunk into the base of unequal.

the valves; shell foliated, with irregular blisters (apparently accidental) within. Fig. 59 .

a. An oblong callosity in the base of the shell.

B. No callosity

(1) I have only been able to procure the mould of a Diceras to draw from; there is but one species known, and that in a fossil state. Guvier does not see any essential difference between it and the Chamce. It is found at Mount Salève, and in the environs of $S t$. Mihiel in Lorraine. Interior moulds of a smaller size have been found at Clevre, near Ferte-Benard, in the department of Sarthe, and in that of Calvados.

(2) Almost all the Camacea adhere to rocks, corallines, and frequently to each other. Foss. in the Green Sand, Kelloway Stone, at Piedmont, Angers, Plaisance, Grignon.

(3) This is a very rare shell, and is sold at a considerable price : the blisters found on its inner surface, have never been satisfactorily explained. EastIndies and Madagascar. 


\title{
DIVISION XII. CORBULACEA.
}

\author{
GENERA.
}

1. Corbula. Lam. M. F.

Shell regular, inequivalved, inequilateral; not, or scarcely gaping. Fig. 57 .

1 cardinal tooth on each valve, conical and fixed in the hollows. (1) curved; a hollow on the side : no lateral teeth.

2. PANDorA. Lam. M.

Shell regular, inequivalved, inequilateral, transverscly oblong; one valve flattened, the other convex. Fig. 58 .

2 oblong cardinal teeth, diverging and unLigament interior.(2) equal, on the flat valve 2 oblong hollows on the other.

\section{Productus. Soiverby.}

Foss.

Equilateral, inequival- Hinge transverse, lived, margin reflexed; the near. one valve convex, the other flat or concave exterually; frequently furnished with spines. Fig. $61.6 \% .63$.

(1) Some of these live within stones. M. de Ferussac has a fresh-water specimen in his splendid collection of terrestrial and fluviatic shells. Foss. at Grignon, Bourdcaux, Italy, Courtagnon.

(2) Mediterranean and British Ocean. Foss, in the Limestone Rock, DerbyshirePeak Rock. 


\section{(19) \\ DIVISION XIII. TRIDACNEX.}

\section{GENERA.}

1. Tridacna. Brug. M.

Shell regular, equivalved, inequilateral, gaping, upper edge always undulated; with a byssus. Fig. 51 .

2 compressed cardinal teeth, unequal, anterior. exterior : muscular impression elongated, attached. . (1)

\section{Hippopus. Lam. M.}

Equivalved, regular, inequilateral. Fig. 49.

2 compressed, unequal, cardinal teeth.
Ligament marginal, exterior. (2)

(1) These shells sometimes attain an enormous size, and are the largest and heaviest known. Those which contain the holy water in the Church of St. Sulpice, at Paris, were presented to Francis the First, by the Republic of Venice. The tendinous byssus, which suspends them to the rock, is so thick and tenacious, that it is ouly to be separated by a hatchet; the flesh of the animal is eatable, but very hard. Foss. Normandy, in the environs of Dives. .

(2) There is but one species known. 


\section{$(20)$ \\ DIVISION XIV. MYTILACEE. \\ GENERA. (1)}

1. Modrola. Lam. M.

Shell sub-transverse,

No teeth; hinge lateequivalved, regular, pos- ral and linear. terior side very short: beaks almost lateral, inclined on the short side. Fig. 64 .

2. Liтhodomus. Cuv. M.

Almost equally rounded at both ends: beaks near the posterior end. (3) Fig. 65.

3. Mytalus. (4) Iin.M.F.

Equivalved, regular, pointed at the base; fixed by a byssus; beaks almost straight, terminal, pointed. Fig. 66.

a. Shell furrowed longitudinally.

R. No longitudinal furrows.

4. Pinna. Lin. M.

Longitudinal, wedgeshaped, equivalved, gaping at the summit, pointed at the base; beaks straight : byssus extremely fine and silky. Fig. 67 .

(1) The greater number of Hytilacece attach themselves to marine bodies, by a byssus.

(2) These do not attach themselves by a byssus. Foss. in the London Clay, Grecn Sand, Upper Oôlite, Clunch Clay, Alum Shale, Blue Lias, at Grignon, Plaisance, Vaches-Noircs, St.Jean d'Assé, Chauffour, Domfront, Tanrie.

(3) Lamarck does not admit this as a distinct genus. They have a byssus, which does not grow after they have lodged themselves in stone. The manner in which the Lithodomi, Pholades, and some otlers, hollow out the stones which they inliabit, has given place to much discussion : some believe it to be effected by the mechanical action of the valves; others by dissolution. One of the Lithodomi is very common in the Mediterranean, where it is esteemed from its agreeably pungent taste.

(4) Towards the end of autumn, we frequently find small crabs, who take shelter in the shells of the Mytili, without injuring the animal. M. de Ferussac has shewn me what is supposed to be a fresh-water Mytilus. They are frequently eaten, but are dangerous in any quantity. Besides the cardinal, they have a thinner ligament, fixed within, towards their superior extremity. Dr. Leach first determined its use to be that of moderating the effects of the elasticity of the cardinal ligament, without obliging the muscle of attachment to contract itself : there is another at the base of the shell, which probably strengthens the cardinal attacbment. The Mytiloides found in while chalk and chalk tu fau, is so thin and fragile, and adheres so closely to the rock in which it is found, that the hinge is unknown, and it is merely placed temporarily with the Mytili, from its apparent resemblance. It varies considerably in form and size, and the folds are sometimes very delicate. Vide fig. 63.

(5) The byssus of the Pinn is long, fine, lustrous, silky, and full; it takes 


\section{DIVISIOY XV. MALLEACEE.}

GENERA.

1. Crenatula. Lam. M.

Sub-equivalved, flatten-

Hinge lateral, crenaed, foliated, somewhat ir- ted, callous. regular. Fig. 69.
Liganent linear, marginal, received in the hollows of the crenated. hinge; no passage for a byssus. (1)

\section{Perna. Lam. M.}

Sub-equivalved, flattened, irregular; substance end of the hinge. Fig. 72.

Hinge linear, marginal, composed of transverse, parallel, sulciform teeth. scaly; beaks small, at one

Ligament inserted between the teeth : a posterior sinus, gaping under the extremity of the hinge, for the byssus. (2)

3. Inoceramus. Sowerby.

Foss.

Inequivalved, one beak curved inwards; substance Hinge straight, with teeth like the Perna. scaly. Fig. 74. 75
Ligament like that of the Perna; no passage for a byssus. (3)

\section{Malleus. Lam. M.}

Sub-equivalved, rugged, irregular, sub-lobed at the base; beaks small and diverging. Fig. 73.

Hinge without teeth : an elongated conical hol- terior, inserted on the low, situated under the short area and slope of beaks, traversing the each valve: with a bysarea of the ligament sus. (4) obliquely.

every kind of dye, and is frequently woven, in Italy, into borders for shawls, elc. The shells are found half buried in the sand. Foss. at Parma, Grignon. The species found at the latter place, is distinct from all others; it is rather narrow, three inches and a half long, and slightly rounded at its upper edge, covered within and witbout with mother-of-pearl, and longitudinally furrowed, without offering any traces of scales or projection; the strix of growth only forming some faint wrinkles on the upper part.

(1) They are very rare, little known, and principally found in warm climates, enveloped in sponges.

(2) Foss, in Blue Marl, Alum Shale, Virginia, Alsace, Vaches-Noires, Bursundy.

(3) Foss. in Blue Marl, Chalk, Clay, M. Brongniart wishes to separate the Catillus (fig. 84) from the Inoceramus; both are found in chalk, but in beds distant from each other. An entire specimen of the Catillus, which certainly differs from the Inoceramus, has not yet been discovered. Its hinges, from their fragments (fig. 84. a. b.), resemble those of the Perna.

(4) These shells are very rude in appearance; the animal occupies but a small space, which is covered with mother-of-pearl. 
5. Avicula. Lam. M.

Inequivalved, fragile, base transverse, straight,
its extremities advanced and the anterior caudiform; a slope on the left valve: beaks small.

Hinge linear, 1 cardinal tooth on each valve under the beak.
Area of ligament marginal, narrowed like a channel, not crossed by the byssus. (1) Fig. 70.

6. Meleagrina lam. M.

Sub-equivalved, almost a round cornered square; scaly; without cardinal Hinge linear, without teeth.

Area of ligament marginal, long, almost exterior, dilated in the middle : A sinus at the edge; straight; without posterior base for the anterior tail. Fig. 71. byssus, the left valve being narrow and sloped. (2)

(1) Foss. in the London Clay, at Grignon, Bourdeaux.

(2) The most celebrated species, is the Mytilus margaritiferus of Linnæus; the inside is covered with the most beautiful mother-of-pearl, which is employed for ornamental purposes, and its pearls, so celebrated in the East, are dived for on the coasts of Ceylon, Cape Cormorin, and the Persian Gulph. It is also found in New-Holland and the Gulph of Mexico, 


\section{DIVISION XVI. PECTINIDES.}

\section{GENERA.}

1. Pedum. Lam. M.

Inequivalved, a little auricular, gaping and sloped at its inferior valve : beaks unequal, wide apart. Fig. 78.

2. LrMA. Brug. M.

Longitudinal, sub-equivalved, auricular, a little gaping on one side, beaks wide apart. Fig. 79.

3. Plagiostoma. Sowerby. Foss.

Sub-equivalved, subauricular; base, transverse, straight; beaks somewhat distant, their interior sides in transverse furrows flattened externally, one straight, the other inclined obliquely : shell thin. Fig. 82.

4. Pegten. Lam. M.

Regular, inequivalved, apricular, lower edge transverse, straight; beaks contiguous. Fig. 80 .
Hinge without teeth.

Ligament partly exterior, inserted in an oblong channelled hollow, sunk in the interior of the beaks. (1)

Ligament partly exterior, received in a cardinal hollow. (2)

Ligament received in a conical cardinal hollow below the beaks, parlly interior, opening without. (3)

Ligament received in a triangular, interior, cardinal hollow. (4)

a. Ears equal or almost equal.

R. .. unequal.

(1) There is but one species known, which comes from the Isle of France, and the Indian Seas; it is very rare and precious.

(2) There is a beautiful species in the Mediterranean, the animal of which is eaten. Foss, in the Under Oôlite; Grignon, Italy, Marl-pits of Touraine.

(3) These shells are difficult to recognise, from the hard stone which fills then ; they are only known in a fossil state, and are found in the Upper Chalk, Lower Chalk, Blue Lias, While Lias, Portland Rock, Kelluway Stone, Upper Oülite, Fuller's-earlh Rock, and at Carantan, Manert, Château de Loir, Bourdeaux.

(4) The greater number are ornamented with brilliant and various colors; one species, the Ostrea maxima of Linnæus, is eaten. Foss. in the Lower Cha'k, Green Sand, Chalk Marl, Kelloway Stone, Bedford Limestone, Upper Oólite, Under 


\section{$(24)$}

5. Plicatula lam. M.

Inequivalved, narrowed at the base, upper edge rounded, sub-folded; beaks unequal, without external furrows. Fig. 76.

\section{Spondyuus. Lin. M.}

Inequivalved, adherent, auricular, with thorns or rugged; beaks unequal; inferior valve with an external cardinal area or heel, flattened and divided by a furrow, and enlarging with age. Fig. 77.

7. Podopsis. Lam. Foss.

Inequivalved, sub-regular, adhering by its inferior beak; the inferior valve the largest and most convex, and its beak more advanced. Fig. 81 .

8. Hrppopodum. Sowerby. Foss.

Equivalved; valves subbilobed: a heart-sliaped cavity behind each beak. Fig. 83.
2 strong teeth oll each valve.

Ligament interior, received in a cardinal hollow, between the teeth. (1)
4 strong cardinal teeth .on each valve; an intermediate hollow communicating at the base with the external furrow.
Hinge without teeth.
Ligament interior, its remains seen in the furrow without. (2)

Ligament exterior. (4)

Oólite, at Grignon, Parnes, Bourdeaux, Doué, Bailleul, Mont-Marius, Turin, Venice, Ferté-Benard, Perpignan, Mans, Coulaines, Décize, Chauffour, Boutonnet, Sienna, Marsigni."

(1) America, Jamaica. Foss. Paris, Dax.

(2) Spondyli are frequently eaten; their shells are often tinted with the liveliest colors, and adhere to all sorts of substances. Several species abound in temperate climates, but they are principally found in the seas of warm countries. Foss. at Turin, Grignon, Havre.

(3) Known only in the fossil state, and is found in England, in France, at Touraine, Mcudon, Dax, and in Iialy.

(4) Known only in the fossil state, and found in England at Colebrook Dale, at Toddenham in Gloucesiershire, at Fenny Compton, and at Chcltenham in upper beds of Lias. 


\title{
DIVISION XVII. OSTRACER.
}

\author{
GENERA.
}

1. Gryphen. Lam. M.

Inequivalved ; inferior valve large, concave, terminated by a projecting beak, curved in a spire; upper valvesmall, smooth, like an operculum. Fig. 86 .
Hinge without teeth ; a cardinal hollow, ob- sion on each valve. (1) long, arched.
One muscular impres-

\section{2. Ötraea. Lin. M.}

Shell adherent, inequivalved, irregular, beaks wide apart, becoming very unequal with age, the upper valve displacing itself during the life of the animal. Fig. 85 .
Hinge without teeth, hollow of the inferior valve increasing wilh age.

๙. Edges of the valves simple or undulated, but not folded.

R. .. . . . . distinctly folded. (2)

(1) With the exception of one species (G.angulata) all those known are fossil, and are found in Alluvia, Crag Marl, Portland Rock, Kelloway Stone, Under Oólite, Blue Lias, Derbyshire Peak Limestone, and at Mans, Breuille, Nevers, Champagne, Gazonfier, La Rochelle, Rochefort.

(2) The most remarkable circumstance attending the Oyster, (whose functions seem to be very limited), and which we only observe in it and the $S$ pondylus, is, that in proportion as it grows older and larger, it displaces itself in its shell, and gradually leaves the base of its lower or convex valve, displacing the upper valve at the same time, as well as its ligainent; consequently, the lower valve frequently forms a beak or heel of considerable length. The hollow in which the ligament has been successively placed, elongates as the shell increases and becomes a gutter, transversely striated, whilst the ligamental hollow of the upper valve scarcely grows at all. Its fecundity is astonishing. The Ostrca cdulis is that which is most frequently eaten. Foss. in the London Clay, Bedford Limestone, Chalk, Green Sand, Blue Marl, Clay, Coral Rario, Clay in Upper Oólitc, Oak-tree Clay, at Mans, Grignon, Angers, Cany, Champagne, Neuville, Maestrieht, MontMarius, Bourdeaux, Boutonnet, Seeaux, Montmartre, Roqueneourt, Longjumeau, Piedmont, Houdan, Mcudon, St.Saturnin, Valogne. 
3. Vulsella. Lam. M.

Shell longitudinal, subequivalved, irregular ; beaks equal. Fig. 89 .
Hinge with a projecting callosity on each
valve, depressed above, bearing the impression of a conical obliquely arched hollow.

\section{Placuna. Lam. M.}

Irregular, flattened, sub-equivalved, of a thin longitudinal sharp ribs foliated substance and al- in the form of an inmost transparent. Fig. 87. verted $\mathrm{V}$ on one valve, and two corresponding impressions on the other.

\section{Aломia, Lin. M.}

Inequivalved, irregular, Operculum small, el- Ligament interior and adhering by the oper- liptic, bony, with the cardinal. (3) culum; one valve perfo- interior muscle of the rated, generally flattened, animal attached. with a hole or slope at its beak; the other a little larger, concave and entire. Fig. 90.

(1) They are frequently found in the sponges of the Indian Ocean and NewHolland. Foss. at Grignon.

(2) M. Leschenault found pearls in the Placuna sella, which differ in shape and appearance from those generally found, fig. 88. Indian Ocean, Red Sea.

(3) The Anomia, like the Ostrex, always remain in the same place, and are found in all seas. 


\section{DIVISION XVIII. RUDISTES.}

GENERA.

1. Spherulites. Lam.

Foss.

Shell inequivalved, orHinge unknown. (1) bicularly globulous, a little depressed above, armed exteriorly with large subangular horizontal scales : upper valve smaller, flat, like an operculum, with two unequal sub-conical tuberosities (curved and projecting) within; inferior valve larger, a little swelled; radiating scales outside the edge forming a crest or projecting keel by a fold of the inner edge. Fig. 93.

2. Radiolites. Lam. Foss.

Inequivalved, striated exteriorly, striæ longitudinal, radiating : lower valve turbinated, largest ; upper valve convex, or conical, like an operculum. Fig. 92.

3. Calcrola. Lam: Foss.

Inequivalved, triangular, turbinated, flattencd underneath : the large valve hollowed like a hood, obliquely truncated at the opening, with its cardinal edge straight, transversal, a little sloped and sub-dentated in the middle, and its upper edge arched; the small valve flattened, semi-orbicular, in the form of a lid, having a tubercle on each side of its cardinal edge, and; in the middle, a hollow with a small scale. Fig. 94.

(1) There is but one species known, from the Isle of Aix.

(2) These shells are only found in beds of antient formation; the Pyrenees contain a considerable number. They are the same as the Ostracites of La Peyrouse, and the Acardines of Cuvier. The Acardo of Bruguicre, alopted by Lamarck, is a double epiphysis of the vertebra of a Cetacea.

(3) In the crvirons of Juliers. 
4. Birostrites. Lam,

Foss.

Inequivalved, valves elevated at their disk, unequal, diverging, almost straight, like horns, one enveloping the other at the base. Fig. 95.

5. Discina. Lam. Foss. (2)

A ronnded oval, a little depressed; valves of equal size, each with a very distinct, central, orbicular disk: disk of upper valve not pierced, with a protuberance in the middle; that of the lower, very white, divided by a transversal cleft.

\section{Chania. Brug. (3)}

Inequivalved, sub-orbicular, inferior valve smooth, pierced internally by three unequal oblique holes, upper valve very convex, with two projecting callosities within. Fig. 91 .

7. Dianchors. Sowerby. Foss.

Inequivalved, adherent; the attached valve with an opening instead of a beak, the other valve beaked and eared. (4) Fig. 96.

(1) The valves diverge like a very open $V$, appearing as if one proceeded from the base of the other; it is always the shortest which is enveloped.

(2) It is found on the coasts of Great-Britain. There is no trace of a hinge or ligament, or any distinct muscular impression.

(3) The Crania personata is said to be the only species living. The fossils are found in Sweden; at Meudon, Nehou.

(4) Found in Lourer Chalk and Green Sand. 


\title{
DIVISION XIX. LINGULACE无.
}

\author{
GENERA.
}

1? Orbicula. Lam. M.

Sub-orbicular, inequivalved, lower valve very thin and flat, adhering to (1)

Hinge not apparent. marine bodies, upper valve sub-conical, beak more or less elevated. Fig. 97.

\section{Terebratula. Brug.M.}

Inequivalved, regular, sub-trigonal, attached to marine bodies by a short tendinous pedicle; the largest valve with the beak advanced, frequently curved, pierced at the summit by a round hole or slope ; 2 ramifying and almost bony appendages within, slender, forked, and differently branched, springing from the disk of the small valve, and serving as a support to the animal. (2) Fig. 98.

a. Shell smooth, without strix or longitudinal furrows.

l. .. longitudinally furrowed. (2)

(1) The lower valve, which I have not been able to procure or figure, is sometimes so thin that it is scarcely perceptible. The European seas are said to produce a small species. Is it a bivalve, or a Hipponyx?

- (2) They appear to inhabit deep seas, for the fossil species exist in secondary formations, with Ammonites, Gryphites, Belemnites, etc. Many, however, have been found in a recent state. Mi. Valenciennes has observed, that the hole of thic beak of the larger valve is gencrally round, and when it offers only a longitudinal notch, it is from the absence of two small lateral and accessory pieces, which, when united, complete the opening; this hole is also sometimes completed by the cdge of the smaller valve. The little tendinous cord which procceds from the hole of the T. Caput-serpentis, divides at the end into a bunch of byssiform filaments, which serve to fix the animal to bodies under the water. Foss. in Gravel and Alluvial Clay, Sand, Crag Marl or Soft Limestone, Upper and Lower Chalk, Chalk Marl, Green Sand, Bedford Limestone, Clay under Limestone, Great Oölite, Under Oólite, Fuller's-earth Reck, Blue Marl, Marston Marble, Blue Lias, Coal Shale, Limestone Roek, Mountain Limestone, Derbyshire Pcak.Limestone, at Meudon, Trowre, St. Saturnin, Mans, Domfront, Valogne, Plaisance, Bourges, Grignon, Turin, Cologne, Haure, Coulaines, Mont-Marius, Maestricht. 
3. Lingula, Lam. M.

Sub-equivalved, flat(1) tened, oblong-oval, truncated at the summit, a littlc pointed at the base, raised on a fleshy tendinous pedicle affixed to marine bodies. Fig. 99.

\section{SpIrifer. Sowerby. Foss.}

Equilateral, inequivalved, one valve with a large angular sinus along the inside of the beak. Fig. 101.

Hinge transverse, long and straight, two spirally coiled linear appendages to the hinge, nearly filling the shell. (2)

\section{Magas. Sowverby. Foss.}

Equilateral, inequivalved, one valve with an angular sinus along an incurved beak; back of the other valve straight, with two projections near the Line of hinge straight, a partial longitudinal septum with appendages attached to the hinge. within. (3) middle. Fig. 100.

\section{Pentamerus. Somerby.}

\section{Foss.}

Equilateral, inequivalved; one valve divided by a longitudinal internal septum into two parts, the other by two septa into three parts or valves; beaks incurved, imperforate. (4) Fig. 103, 104.

(1) There is but one species known; from the Indian Seas. Foss. in the London Clay, Crag Marl, Coal Shale.

(2) The Terebratula spirifera of Lamarck, which is only known in a fossil state, and is fou nd in the Derbyshire Peak Limestone.

(3) In Chalk.

(4) I have hesitated in putting this shell amongst the Bivalves, suspecting that the septa mentioned by Mr. Sowerby, may prove to be a number of valves soldered together; but until it is perfectly known, it may be premature to alter his classification of it as a Bivalve. It is found in the Derbyshire Peak Rock. I add Mr. Sowerby's figure and description of the Axinus (fig. 102), being too imperfect to admit of its classification, as memoranda for the geologist. " A free, cquivalved, transverse, bivalve; anterior side very short; posterior " side produced, truncated, with a lunette near the beaks : hinge with a long " oblique ligament placed in a furrow. It is much to be regretted that there " is very little probability of discovering the interior structure of the hinge, " but I suspect it has no teeth. The shell appears to be thin, but I can trace " neither the cicatrices of the muscles, nor of the edge of the mantle in the "Angulatus, which I consider the type of the genus." 


\section{$(31)$ \\ DIVISION XX. CORNIF́ORMES.}

GENERA.

1. Otion. Lam. M.

A membranous tunic with an opening, at the summit of which are two small triangular testaceous valves. separated, but adhering to the tunic. (1) Fig. 117.

\section{DIVISION XXI. SERIALES.}

\section{GENERA.}

1. Chiton. Lin. M. (2)

A series of longitudinal, imbricated, transverse moveable valves, varying in number from 6 to 8 , held together by a coriaceous ligament, sometimes shagreened, hairy, and even thorny. Fig. 105.

2. Ghitonellus. Lam. M.

(3)

'A series of longitudinal valves, disposed like a narrow ribbon on the middle of the back, not held together by a ligament. Fig. 106.

(1) Northern Seas.

(2) The valves have been found separated in a fossil state at Grignon, but the ligament which held them together having been destroyed, it is difficult to determine the species. Cape of Good Hope, America, European and Southern Seas.

(3) New-Holland. 


\section{DIVISION. XXII. PEDICULATE.}

\section{GENERA.}

3. Anatifera (Anatifa). Lam.

Five unequal valves, two on each side, and one dorsal, like a kcel; valves united by a membrane, like a flattened cone supported on a tubular pedicle. (1) Fig. 118.

4. Pollicipes. Leach. M.

Valves thirteell or more, the lower marginal, much smaller, compressed, and supported on a wrinkled, or scaly pedicle. (2) Fig. 119.

5. Cineras. Leach. M.

Five valves, oblong and separated, two at the side of the opening of the membranous tunic, and the other's dorsal. (3) Fig. 120.

(1) The species most numerous in our seas, was called Lepas anatifera by Linnæus, from the fable of the Barnacles and Scoters being born from them; it attaches itself to rocks, stones, and keels of vessels, etc. According to Cuvier, it varies in the number of its valves.

(2) European and Indian Seas.

(3) British Ocean. 


\section{DIVISION XXIII. SESSILES.}

GENERA.

6. Balayus. Lam. M.

Fixed, conical, trnncated at summit, closed at the bottom by a testaceous adhering plate, open at the top, sub-trigonal or elliplic. Fig. 107, 110.

\section{Coronula. Lam. M.}

Valves altogether appearing sub-orbicular, coniform, truncated at the extremities; divisions or partitions very thick, hollowed by radiating cells. Fig. 111, 112.

8. Acasta. Leach. M.

Sub-conical ; cone formed of six lateral unequal valves, having an orbicular plate at the bottom, concave internally, resembling a goblet or patella. Fig. 116.

9. Greusia. Leach. M.

A convex cone, composed of four unequal valves, distinct by the sutresu. Fig. 114.

10. Tubicinella, Leach. M.

Valves forming a tubulous straight shell, attenuated towards the base, truncated at both ends, open at the top, and the base closed by a membrane, furnished with transverse callous pads. Fig. 115 .

(1) They abound in almost all seas, and attach themselves to all sorts of substances. They are found in a fossil state in Italy, and in England in Crag Marl.

(2) They live in the bodies of marine animals, and have even been found, with the Tubicinella, within the fat of whales; they also adhere to shells.

(3) They are found in sponges, and never fix on hard or solid bodies.

(4) These and the Pyrgomae are generally affixed to Madrepores : the Creusias are from the Northern and Indian Seas.

(5) There is but one species known, found on the South American whales, 
11. PYrgona. Savigny.

II.

Valves united, having the appearance of an univalve, sub-globulous, ventricose, pielced at the summit, opening small, and elliptic. Fig. 113.

Operculum bivalred.

\section{OIVISION XXIV. ANIEXE.}

GERERA.

1. TrRebo. Lin. M.

A testaceous, cylindrical, twisted 'ube, open at each end. Shell bivalved, situated posteriorly without the tube Fig. 121.

\section{Aspergillum. Lam. M.}

Tube insensibly narrowing towards its anterior part, where it is open, and widening into a club at the o!her end, which has two valves incrusted into its side; the terminal disk is pierced with scalle:ed sub-tubular holes, having a fissure in the centre. (2) Fig. 126.
2 operculiferous bodies, adhering to the sides of the tubes of the animal. (1)

(1) They are found in wood which has been sunk in the sea. The Popan of Adanson belongs to them ; their shell is enclosed in a thin sheath, which remains attached to the stony bodies in which they are buried. They do much mischief to vessels and piles driven into the sea. They are supposed to bury themselves deeper as they grow bigger, and to hollow out the wood with their valves; their tubes always remaining at the opening, for water and food; their passage is lined with a calcareous crust, which exudes from them and forms a sort of tubulous shell. They are said to have been brought from the Torrid Zone to Holland, and more than once to have threatened that country with destruction, by destroying the wood of the dykes. Foss. in the London Clay.

(2) The common species is from 8 to 10 inches long, and is said to be found attached by its smaller end to the rocks of the Indian seas; which M.-Lamarck denies by asserting that this end is necessarily open. The Red Sea, Indian Seas, New Holland. 
3. Clavagella. Lam. Foss.

Tube attenuated and open anteriorly, terminam ted at the other end by an oval club, compressed, armed with spiniform tubes. Club presenting one valve enchased into the side, and the other free in the tube. (1) Fig. 131.

4. Fistulana. Lam. M.

Tube swelled and closed posteriorly, attenuated towards the anterior extremity, opening at the top and containing a free, equivalved, bivalved, gaping shell. (2) Fig. 125.

5. Septaria. Lam. M.

Tube very long, insensibly attenuated towards the anterior part, and divided interiorly by arched cells, mostly incomplete; shell unknown, but supposed to be bivalved. (3) Fig. 122.

6. Teredina. Lam. Foss.

Tube cylindrical, posterior extremity closed, shewing the two valves of the shell; anterior end open. . (4) Fig. 124.

(1) These are only known in the fossil state, and are found at Grignon and in Italy.

(2) They live in wood, sand stones, and in the shells which they have pierced; the valves of certain species resemble Modiola. They are found in the Indian Ocean; and, in a fossil state, at Grignon, Beynes, Courtagnon, and Sienna.

(3) In the sands of the Indian Ocean.

(4) At Courtagnon, Plaisance. 


\section{DIVISION XXV. CONTORT}

\section{GENERA .}

4. Siliquaria. Brug. M.

Tube attenuated posteriorly, sometimes twisted in a spire at the base, open at the anterior end, with a longitudinal cleft throughout its whole length. (1) Fig. 132.

2. Senpula. Lin. M.

'Tubes grouped or solitary, adherent, with a sound, simple, terminal opening. (2) Fis. 130 .

3. Teruilia, Lam. M.

Tube cylindrical, attesuated at the posterior end, more or less twisted, and affixed to marine bodies; opening round, furnished with a beak, and frequently with firom one to three teeth. (3) Fig. 129.

An orbicular, calca reous, simple operculuin

4. Chymene. Savigny.

M.

Tube thin, open at each end, incrusted without with sand and fragments of shells. (4)

(1) When the animal has left its shell, we sometimes find transverse septa ; the lateral cleft is sometimes very indistinct. Indian Seas. Foss. at St. Clément de ta Plaie, Grignon,

(2) Foss. in the London Clay, Woolwich Loam, and Green Sand, in Italy, at Dax, Grignon, Bayonne, Montbart, Mans, Siez, Touraine.

(3) Foss. in Chalk Marl, Green Sand, Upper Oölite.

(4) The only known species is from the Red Sea. The tube of the Arenic ola of Savigny, found in the sands of the European seas, is but inperfectly known. 


\section{$(37)$ \\ DIVISON X゙XVI. SUBREGULARES.}

\section{GENERA.}

1. Dentalium. Lin. M.

Tube almost regular, slightly curved, insensibly attenuated at the posterior end, open at each extremity. Fig. 134.

a. Tubes with ribs or longitudin al strix.

ß. .. perfectly smooth and simple. (1)

\section{Pectinaria. Lam. M.}

Tube membranous, like a reversed cone. Fig. 135.

\section{Sabellaria, Lam. M.}

Tubes numerous, united in a common mass, alveolar above, composed of grains of sand and fragments of shells ; orifices of tubes hollowed like cups.

4. Terebella. Cuv. M.

Tube long, cylindrical, attenuated and pointed at the base, membranous. (3) Fig. 138.

5. Amphitrite. Brug. M. Tube long, cylindrical, narrowing at base, membranous or coriaceous, generally naked. (4) Fig. 136.

(1) Foss. in London Clay, Crag Marl, Chalk Marl, Green Sand, Blue Marl, at Grignon, Sarthe, Plaisantin, Sienna, Piedmont, Dax, Mons.

(2) European Seas.

(3) There is one species found on the European coasts, very remarkable from the appearance of its tubes, which are formed of large fragments of shells; and the openings of the edges are prolonged into several branches, formed of the same materials : they are chiefly from Norway, Holland, and Carolina.

(4) European and American Seas. There is a large species in the Sonthern Seas, the tube of which, thin and polished, appears to be transversely fibrous, and to be formed of some soft filamentous substance dried. The tubes of another species, when in a compact mass, are so symmetrically arranged that they appear like honeycombs. They are generally very small, found affixed to Fuci, shells, and other marine bodies, in great numbers on the same body, but always isolated. 
6 Spirorbis, Lam. M.

Tube turned in an orbicularspire, discoïd, flattened, and adherent underneath. (1) Fig. 123.

7. Galeola Ria." Lam. M.

Tubes numerous, cylindrical, sub-angular, undulated, collected in tufts, fixed at base; opening superior, orbicular. (2) Fig. 133.

Operculum orbicular galeiform, armed with from 5 to 9 various, testaceous pieces, the mid dle one of which is trun cated, and all attached to the edge of one side

\section{MAarlus, Montf. M.}

Tube convex above, carinated underneath, twisted in a short oval, with a heliciform spire, four turns contiguous, the last prolonged in a straightly undulating line ; scaly folds on the outside, thicker on one side than the other. (3) Fig. 128.

\section{Sabella. Cuv. M.}

Tube composed of fine grains of clay and sand. Fig. 127.

10. Nereis. Cuv. M?

Tube long, horny or membranous.(4) Fig. 137.

(1) Foss. at Grignon.

(2) New-Holland.

(3) The tube is sometimes 3 feet in length. Lamarck supposes the Serpula gigantea of Pallas, to be a species of this genus. Isle of France.

(4) Several of the smaller species contribute to the luminous appearance of the sea. 


\section{N D E X.}

\begin{tabular}{|c|c|c|c|c|}
\hline & age. & & & Page: \\
\hline Acardo........... & 27 & Corbula $_{\imath} . \ldots \ldots \ldots$ & 18 & Inoceramus. \\
\hline casta............ & $\dot{3} 3$ & Corniformes ....... & 31 & Iridina..... \\
\hline Amphidesma...... & 8 & Corbulacex....... & 18 & Isocardia..... \\
\hline Amphitrite........ & 37 & Coronula.......... & 33 & Lima...$\ldots \ldots$ \\
\hline 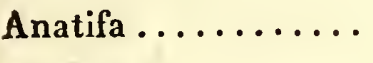 & 32 & Crania........ & 28 & Lingula............. \\
\hline Anatifera......... & 32 & Crassatella........ & 7 & aceæ... \\
\hline 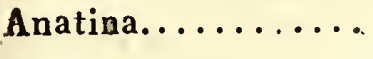 & 6 & Crassina ........... & 11 & Lithodomus ........ \\
\hline Annexæ ......... & 34 & Crenatula.......... & 21 & Loripes........ \\
\hline Anodon............ & 16 & Creusia............ & 33 & Lucina ....... \\
\hline 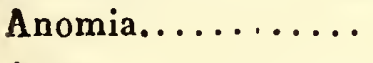 & 26 & Cucullæa.......... & 13 & ia...... \\
\hline Arca $\ldots . . . \ldots \ldots$ & 13 & s............. & 8 & \\
\hline Arenicola.. & 36 & Cypricardia ....... & 12 & Mactra ..... \\
\hline Aspergillum....... & 34 & Cyprina.......... & 11 & Magas....... \\
\hline Astarte $\ldots . . . \ldots$ & 11 & Cyrena........ & 9 & Magilus ...... \\
\hline Avicula........... & 22 & Cytherea.......... & 10 & Malleacex.... \\
\hline Axinus.. & 30 & & & $\mathrm{Ma}$ \\
\hline & & & 58 & \\
\hline irostri & נJ & as ... & 17 & II \\
\hline 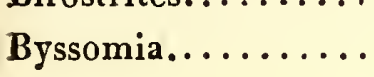 & 20 & Discina & 28 & a.... \\
\hline & & Donax................. & 10 & Mytiloides........ 20 \\
\hline Calceola. & 27 & & 7 & Mytilus.... \\
\hline .. & 9 & Etheria ........ & 17 & \\
\hline Cardita........... & 13 & & & Nereis..... \\
\hline Cardium.......... & 12 & Fistulana... & 35 & Nucula ...... \\
\hline Castalia.......... & 15 & & & \\
\hline Catillus.... & 21 & $a, \ldots \ldots \ldots$ & 8 & Orbicula..... \\
\hline Chama ........... & 17 & Galeolaria......... & 38 & Ostrea......... \\
\hline Chamacex........ & 17 & Gastrochæna....... & 4 & Otion........... 31 \\
\hline Chiton............ & 31 & Gl & 5 & \\
\hline Chitonellus........ & 31. & Gryphæa.......... & 25 & Pandora... \\
\hline Cineras........... & 32 & & & Panopxa........... \\
\hline Clavagella...... & 35 & Hiatella........ . & 12 & Pecten ...... \\
\hline Clymene ......... & 36 & Hippopodium ... & 24 & Pec \\
\hline Contortæ ......... & 36 & Hippopus......... & 19 & Pectinides ..... \\
\hline Corbis. & 9 & Hyria.. & 16 & Pectunculus. \\
\hline
\end{tabular}




\section{IN DEX.}

\begin{tabular}{|c|c|c|}
\hline Page. & Page. & Page. \\
\hline$\ldots \ldots \ldots 23$ & Sabella. & Terebratula \\
\hline Pentamerus... & Sabellaria. . & Teredina.. \\
\hline Perna......... & Sanguinolaria.... & Teredo. \\
\hline Petricola..... & Saxicava........... & Tridacna.. \\
\hline Pholas..... & Septaria $. . . \ldots \ldots \ldots . . .35$ & Trigonia.. \\
\hline .. 20 & Seriales.......... 31 & Tubicinella. \\
\hline Placuna........... 26 & Serpula.......... & Tubicolæ... \\
\hline Plagiostoma........ 23 & Siliquaria ......... 36 & \\
\hline Plicatula.......... 24 & Solenimya .......... & \\
\hline Podopsis.......... 24 & Solen.............. & Unio. \\
\hline Potamophila ........ & Sphærulites ....... 27 & \\
\hline Pollicipes ......... 32 & Spirifer........... 30 & \\
\hline Productus......... 18 & Spirorbis........ & Venerirupis \\
\hline Psammobia......... & Spondylus....... & Venericardia. \\
\hline Psammotea......... & Subregulares... & Venus...... \\
\hline \multirow[t]{2}{*}{ Pyrgoma.......... 34} & & Vermilia... \\
\hline & Tellina .......... 10 & Vulsella. .. \\
\hline Radiolites......... 27 & Tellinoides........ 10 & \\
\hline Rudistes...... & Terebella ......... 37 & \\
\hline
\end{tabular}




\section{PLATES.*}

PHOLADARIE. LITHOPHAGI. SOLENAGEÆ. MYARIE.

Fig. 1. Pholas costaia.

$a . b$. the two hinges.

$c$. one of the inner accessory pieces.

2. Gastrochoena cuneiformis. a. front view of ditto.

3. Saxicava veneriformis.

4. Venerirupis crenata.

$a$. $b$. the two hinges.

5. Petricola distans.

a. outer view of the opposite valve.

6. Solen vagina.

a. b. c. three hinges, shewing each of Lamarck's divisions of this genus.
Fig. 7. Glycimeris siliqua.

8. Sanguinolaria occidens.

9. Panopcea Faujasii.

10. Psmammobia.

$a$. $b$. the two hinges.

11. Psammotea serotina.

$a$. the opposite hinge.

12. Mya.

$a$. the opposite hinge.

13. Anatina truncata.

\section{MACTRACEE， CONCHE.}

Fig. 14. Lutraria rugosa.

15. Mactra.

$a, b$. the two hinges.

16. Crassatella nonacina.

17. Solenimya australis.

18. Amphidesma variegata.
Fig. 19. Ungulina transwersa.

$a$. inner view of the opposite valve.

20. Erycine cardioïdes.

21. Galatea radiata.

$a$. b. the two hinges.

* All the figures not marked with an asterisk, which amount to four-fiftlis of the whole, are original drawings from the objects themselves. 


\section{ILATES.}

Fig. 22. Cyclas rivicola.

$a$. inner view of the valves shewing the hinges.

23. Cyrena syrice.

$a$. $b$. the two hinges.

24. Capsa.

$a$. b. the two hinges.

25. Lucina Pensylvanica.

26. Corbis.

$a$. $b$. the two hinges.

27. Donax.

$a$. the hinge.

28. Cytheria.

a. b. the two hinges.
Fig. 29. Venus.

a. the hinge.

30. Venus.

a. the hinge.

3i. Tellina sulcata.

32. Venericardia imbricata.

33. Cyprina Islandica.

34.* Astarte planata.

35. Crassina.

$a$. $b$. the two hinges.

36. Tellinides Timorensis.

a. b. the two hinges.

37. Loripes. (Lucina lactea.)

CARDIAGE玉. ARCACEE. TRIGONER. TRIDACNE压.

Fig. 38. Cardium.

a. b. the two hinges.

39. Isocardia cor.

a. b. the two hinges.

40.* Hiatella arctica.

a. inner view of the opposite valve

41. Cardita calyculata.

a. the hinge.

42. Cypricardia Guinaiea.

43.* Byssomia. (Mytilus Pholadis.)

44. Arca.
Fig. 45. Pectunculus.

a. inner view shewing the hinge.

46. Nucula Placentina.

$a$. inner view shewing the hinge.

47. Cucullcea auriculifera.

a. inner view.

48. Trigonia pectinata.

a. hinge of the opposite valve.

49. Castalia ambigua.

50. Hippopus maculatus.

$a$. the hinge.

51. Tridacna serrifera

$a$. b. the two hinges. 


\section{PLATES.}

NAIADES. CAMACEE. GORBULACEæ. MYTILACEæ.

Fig. 52. Iridina exotica.

53. Anodonta.

$a . b$. the two hinges.

54. Hyria avicularis.

$a$. $b$. the two hinges.

55. Unio.

$a$. the hinge of the opposite valve.

56. Diceras arietina.

57. Corbula.

58. Pandora rostrata.

59. Etheria elliptica.

$a$. the hinge of the opposite valve.
Fig. 60. Chama.

a. inner view of the opposite valve.

61.* Productus punctatus.

62.* -- longispinus.

63.* -- aculeatus.

64. Modiola.

$a$. inner view of the opposite valve.

65. Lithodomus. (Modiola lithophaga.)

$a$. the hinge.

66. Mytilus.

67. Pinna pectinata.

68.* Mytiloüdes labiatus.

\section{MALLEACER. PECTINIDES.}

Fig. 69. Crenatula nigrina.

70. Avicula crocea.

71. Meleagrina margaritifera.

72. Perna femoralis.

73. Malleus vulgaris.

74.* Inoceramus concentricus. $a^{*}$. profile of ditto.

75.* Inoceramus sulcatus.

76. Plicatula reniformis.

a. inner view of the opposite valve.

b. the second hinge,
Fig. 77. Spondylus ducalis.

$a$. $b$. the two hinges.

78. Pedum spondyloideum.

79. Lima inflata.

80. Pecten varius.

$a$. $b$. the two hinges.

81. Podopsis gryphoïdes.

a. inner view of ditto.

82.* Plagiostoma cardiiformis.

83.* Hippopodium ponderosum. 


\section{PLA'TES.}

\section{OSTRACEÆ. RUDISTES. LINGULACEE, ETC.}

Fig. 84.* Catillus Cuvieri, an impression of the whole shell.

$a . b{ }^{*}$ fragments of the hinge.

85. Ostrea folium.

$a . b$. the two hinges: this figure shews the impression of the wood to which the shell has been attached.

$a$. $b$. the two hinges.

86. Gryphoca arcuata.

87. Placuna papyracea.

88. Three of the pearls found in the Placuna sella.

89. Vulsella ovata.

90. Anomia ephippium, with the two operculum.

$a$. b. the two hinges.

91. Crania Parisiensis.

a. supposed to be the smaller valves of the Crania adlsering to a piece of coral.
Fig. 92. Radiolites turbinata.

93. ${ }^{*}$ Spharulites foliacea.

a. the smaller valve.

94. Calceola sandalina.

$a$. the largest valve separated.

95. Birostrites inequiloba.

96.* Dianchora striata.

97. Supposed to be a valve of the Orbicula.

$a$. inner view of ditto.

98. Tenebratula dentata.

$a$. b. inner views of each valve.

99. Lingula anatina.

$a$. inner view of the opposite valve.

100.* Magas pumilus.

$a^{*}$ profile of ditto.

\section{MULTIVALVES, ETC.}

Fig. 101.* Spirifer oblatus.

$a$. one valve taken away to shew the appendages of the hinge.

102.* Axinus angulatus.

103.* Pentamerus lavis.

104.* -- aylesfordii.

105. Chiton marginatus.

$a$. inner view of ditto.
Fig. 106. Chitonellus striatus.

$a$. profile of ditto.

107. Balanus stalactiferus.

108. Balanus with an operculum.

109. An operculum of a Balanus separated.

110. Balanus perforatus. 


\section{PLATES.}

Fig. 111. Coronula testudinaria.

112. A Coronula with its operculum.

113. Pyrgoma cancellata.

114.* Creusia verruca.

415. Tubicinella Lamarckii.

$a$. the end of the tube, shewing the operculum.
Fig. 116. Acasta glans.

$a$. the lower valve separated.

117. Otion Cuvieri.

118. Anatifera striata.

119. Pollicipes mitrata.

120.* Cineras vittata. (Lepas Coriacea.)

a. b. $c .^{*}$ three of the valyes.

'IUBICOLA.

Fig. 121. Teredo navalis.

$a$. the two valves which assist the animal in piercing the wood.

122. Septaria polythalamia.

$a$. the smaller end of ditto, shewing the passage for the two tubes of the animal.

123. Spirorbis carinata.

a. natural size,

124. Teredina personata.

125. Fistulana gregata.

126. Aspergillum Javanum.

$a$. the larger: end of the shell, shewing the perforations.
Fig. 127. Sabella rupifica.

128. Magilus antiquus.

129. Vermilia rostrata.

130. Serpula arenaria.

131.* Clavagella echinata.

132. Siliquaria levvigata.

133. Galeolaria ccespitosa.

134. Dentalium fasciatum.

135.* Pectinaria capensis.

136. Amphitrite penicillus.

137.* Nereis fimbriata.

138.* Terebella conchilega. 



\section{SUPPLEMENTARY PLATE TO THE MAMMALIA.}

In my Introduction to the Ornithology of Cuvier, I added a new genus of Cheiroptera, established subsequently to the publication of my "Analysis of the Natural Classifications of Mammalia;" and I have now to adjoin the imperfect descriptions of two new fossil genera of Pachydermata, to be inserted in page 72.

1. Elasmothenium. Cuvier. The jaw in its present state, has 4 grinders, regularly increasing in size, and a trace of the alveolus of a fifth (fig. 1.): the teeth are prismatic like those of a full grown horse, the length is double the widlh of the crown, and the base is not divided into fangs, fig. 2-4. The Elasmotherium is distinguished from all other animals; first, by the plates of its teeth forming a very elevated pillar, (which increases like that of the horse and preserves its prismatic form a long time), descending vertically throughout its length, and not dividing into roots until after a considerable time; whilst in other animals, these plates unite very soon into a single bony body, which is almost immediately divided into roots. The three transverse oblique bands, fig. 2. 3. result from double plates of enamel, with a bony substance between, and, apparently, united with the other bands by a cement or third substance, as in the Elephant. The remains of this anima] were found in Siberia; and from the dimensions of its jaw, it must have been larger than the Rhinoceros.

2. Lophiodon. Cuvier. 6 incisor and 2 canine teeth to each jaw; 7 grinders on each side in the upper, and 6 on each side in the lower jaw, with an interval between the canine and the first grinder; points in which it resembles the Tapir, but the last lower grinder has a third ridge (fig. 5.) which is not fouud in the teeth of the Tapir. Again, the anterior lower grinders are not furnished with transverse ridges like those of the Tapir, but present a longitudinal series of tubercles, or a single conical and isolated tubercle. The upper grinders having the transverse ridges more oblique, approach those of the $R$ hinoceros, but the fangs of the ridges are wanting. In some species the ridges of the anterior grinders, becoming more oblique and more arched, fig. 6, approach that form of crescent peculiar to the teeth of the Daman and Rhinoceros, and thus conduct us by degrees to the Palceotherium. The following are Baron Cuvier's remarks on this fossil genus, of which 12 species, varying in size, have already been determined:-

"The most important circumstances connected with these animals, as regards the theory of the earth, are, that all their remains of which it has been possible to ascertain the site, are enveloped in stones or earths exclusively filled with fresh-water shells, and consequently have been deposed in fresh waters; that the animals whose remains are found with them, are either terrestial and unknown, or Crocodites, Trionyces, and Emides, aquatic animals now inhabiting the fresh waters of warm countries; lastly, that in several well determined spots, these beds are covered by others of a decidedly marine origin.

"Consequently, the genus Lophiodon combines with the Palcotherium and Anoplotherium, and other unknown genera which I shall hereafter describe, to demonstrate the certitude of an anterior state of an animal creation which occupied the surface of our present continents, and especially France; and of an irruption of the sea which destroyed this race, to cover its remains with rocks of a recent origin." - Ossemens Fossiles. tom. ii. p. 222. nouv. édit. 


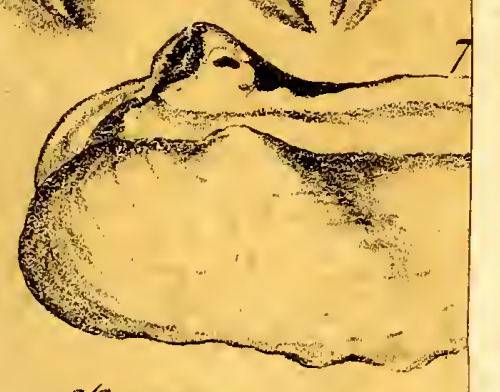

82
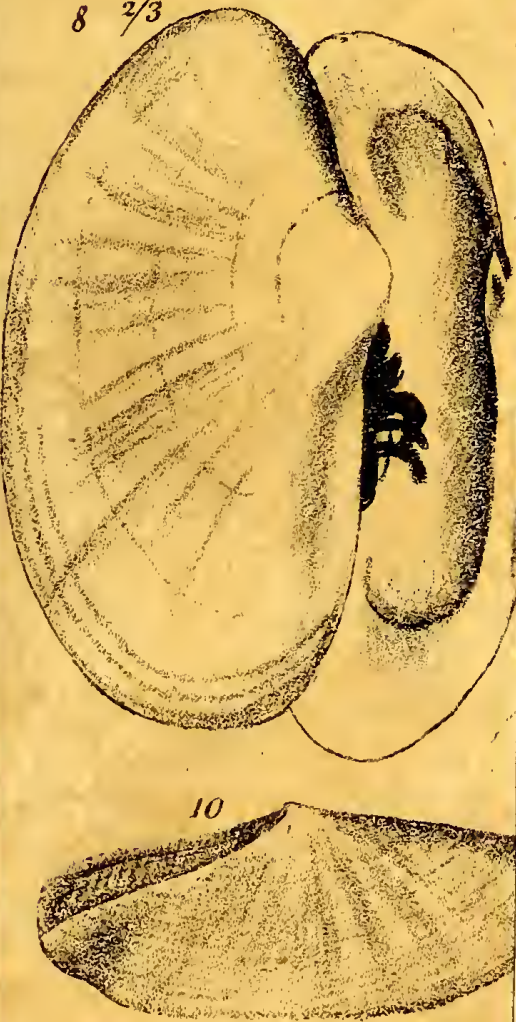






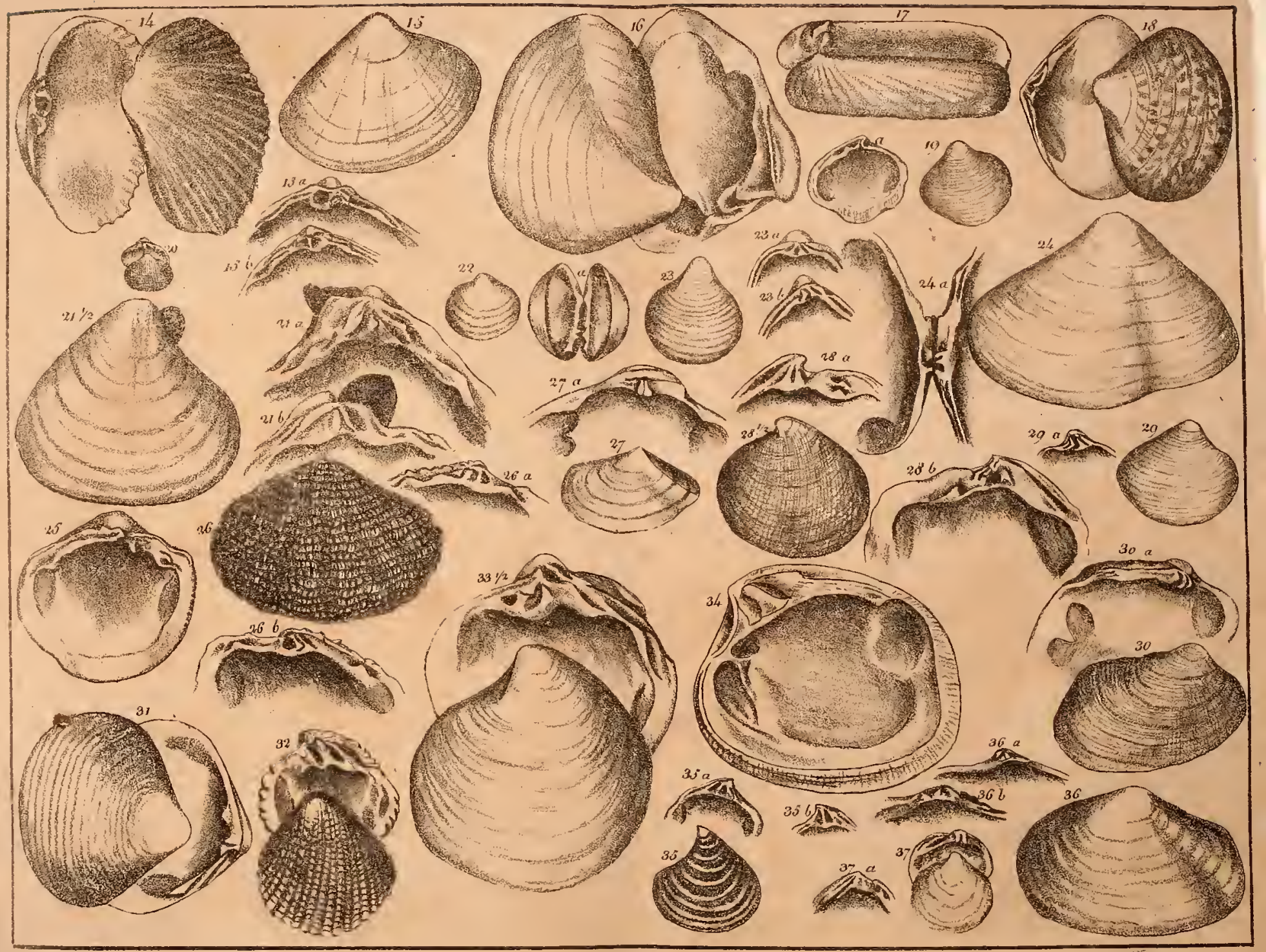

Y. Boudich Lithog. 



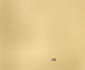




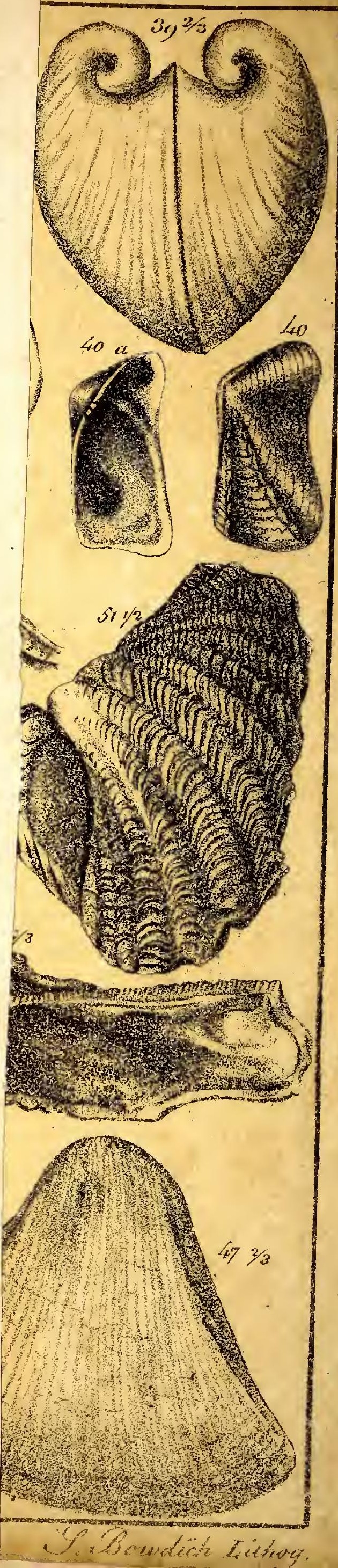



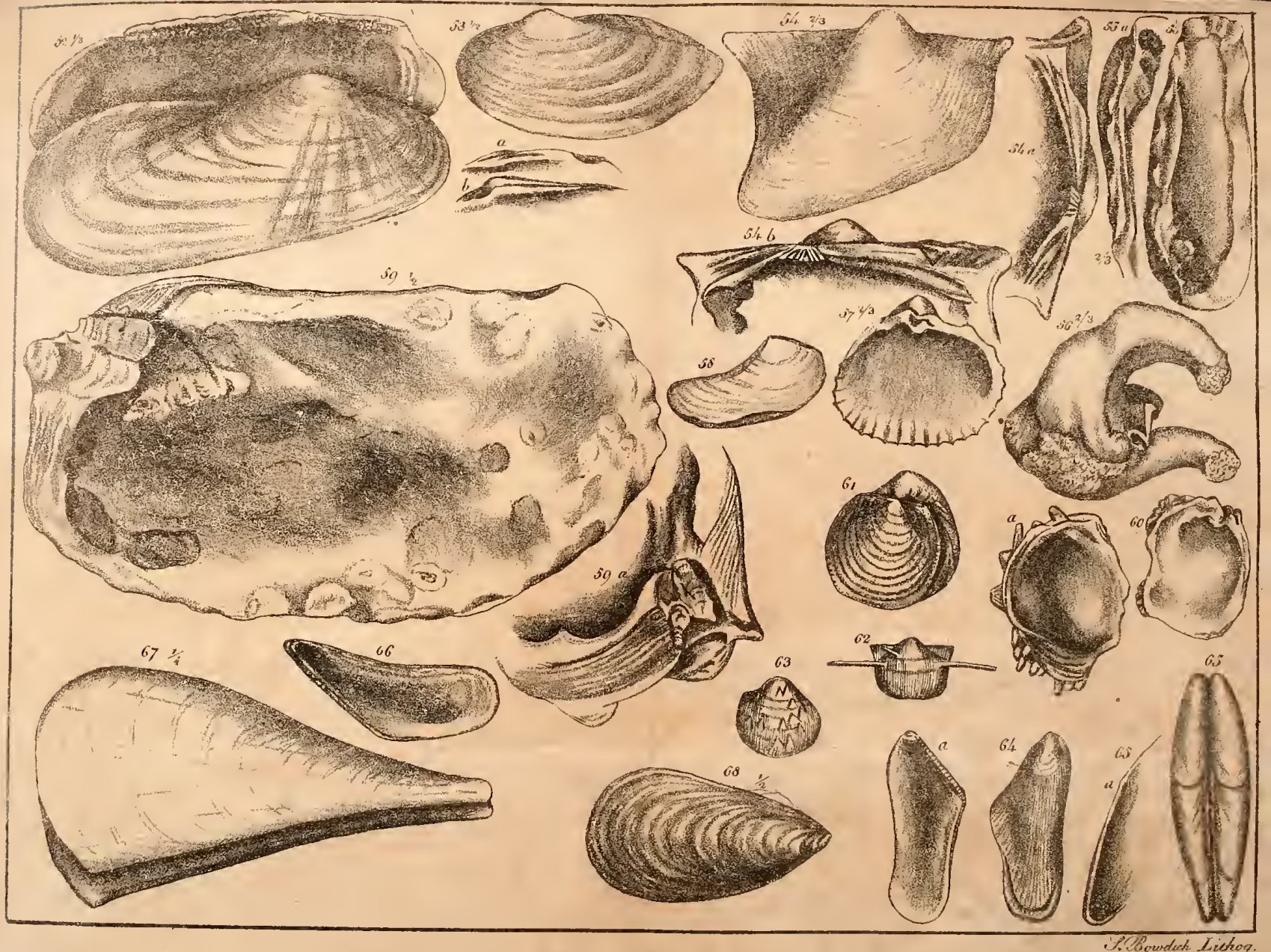





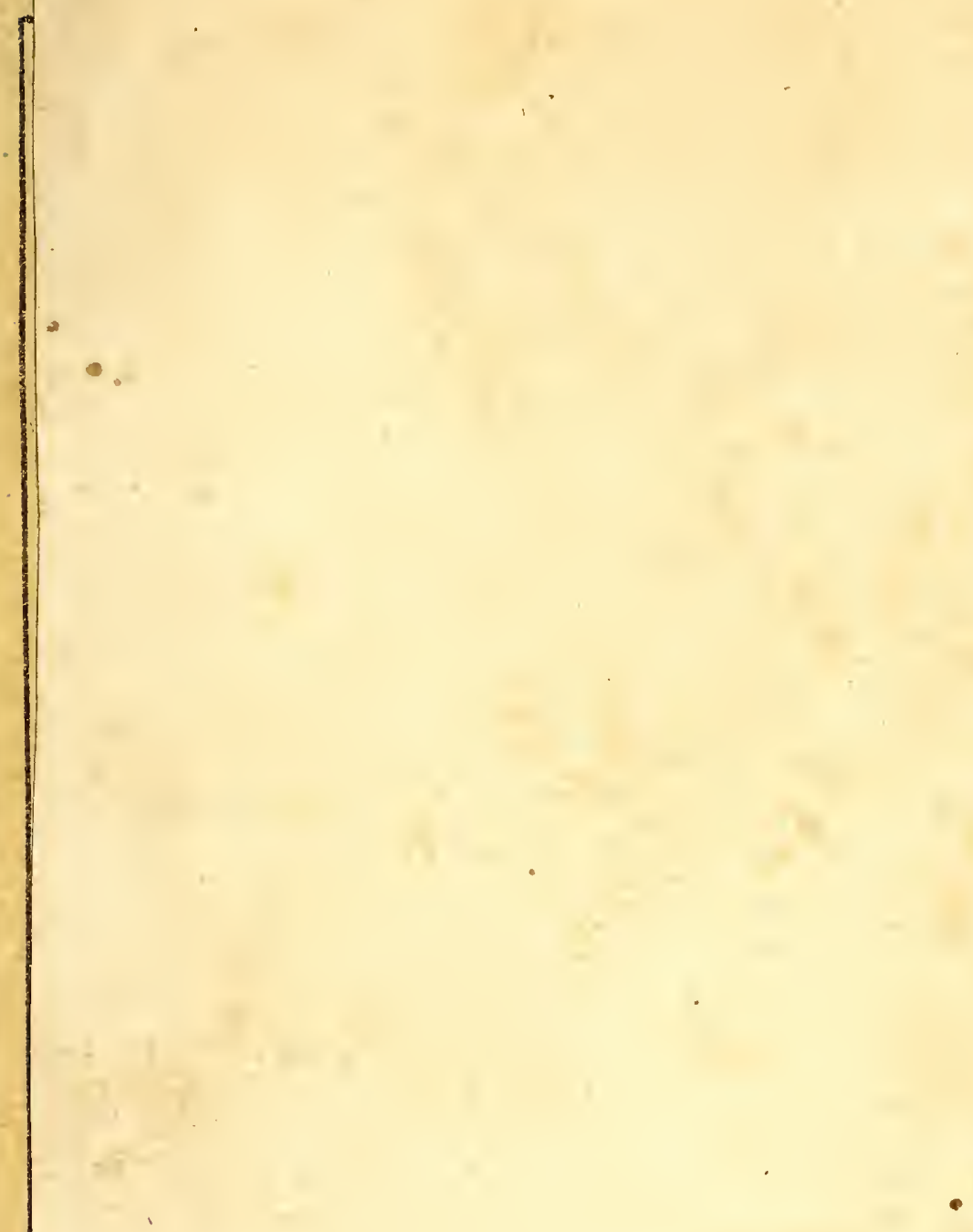





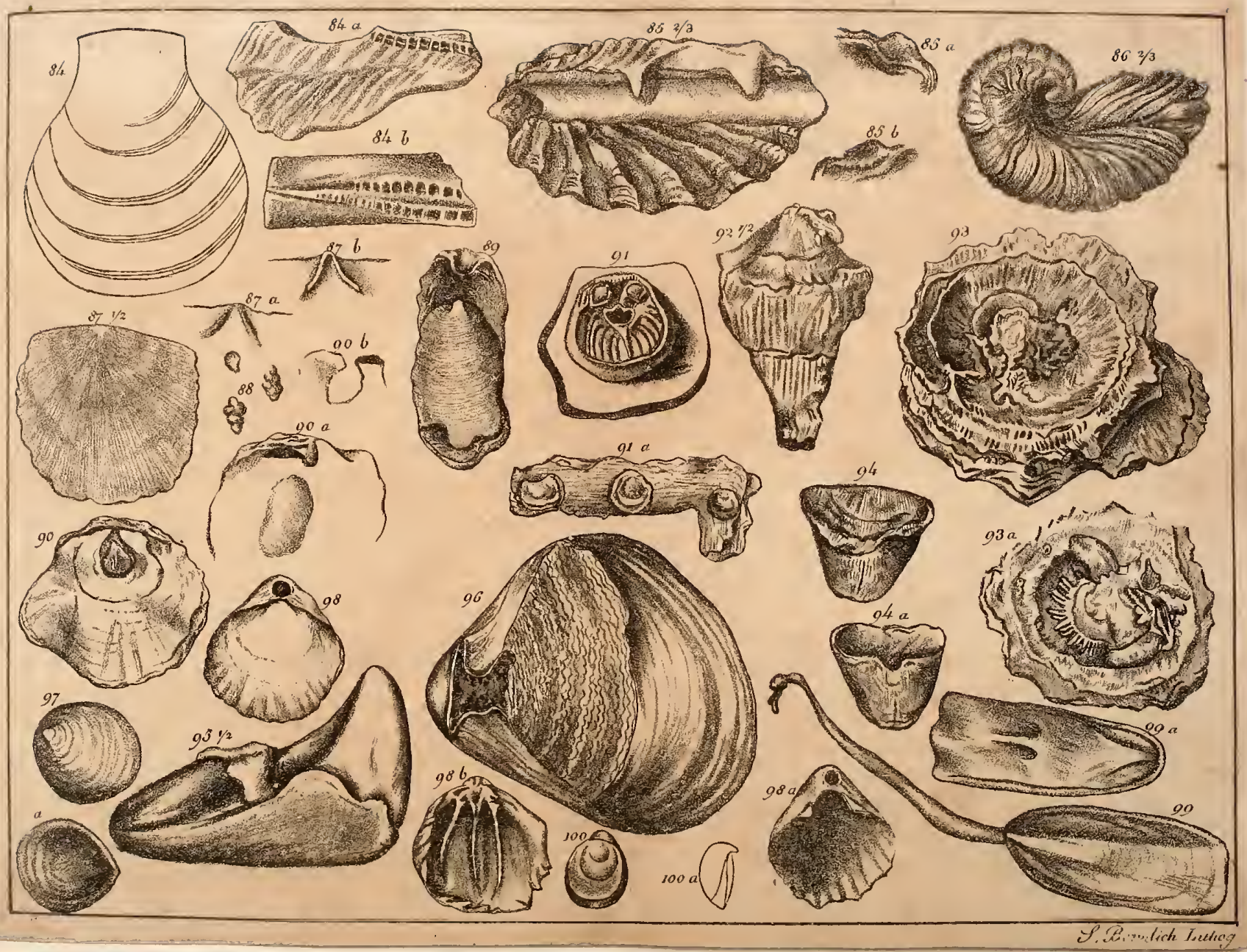





\section{$\bullet$}

$y_{n}=-1+2$

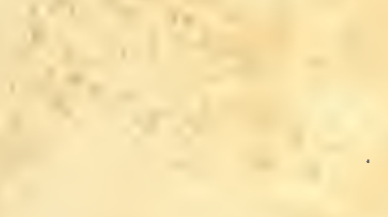




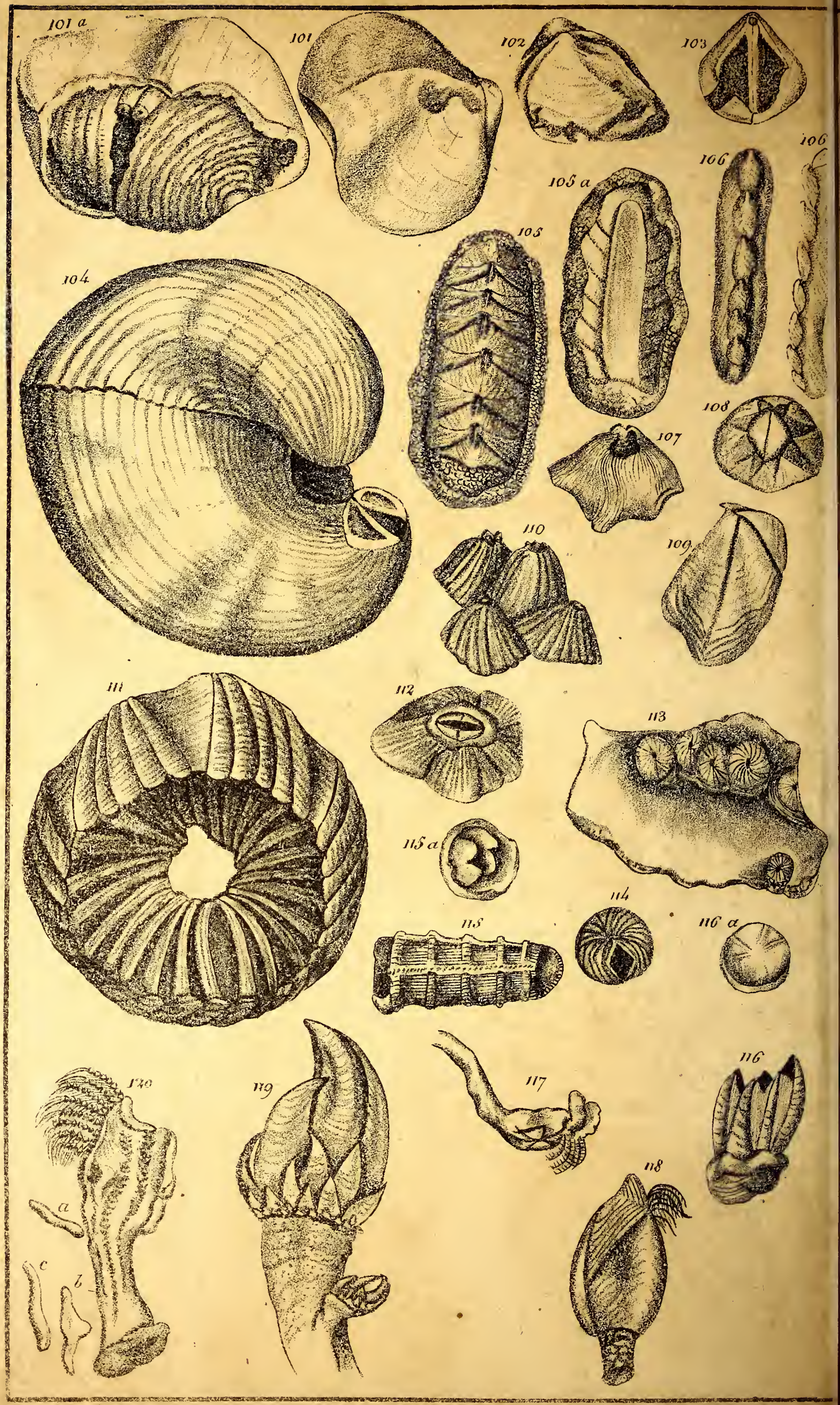




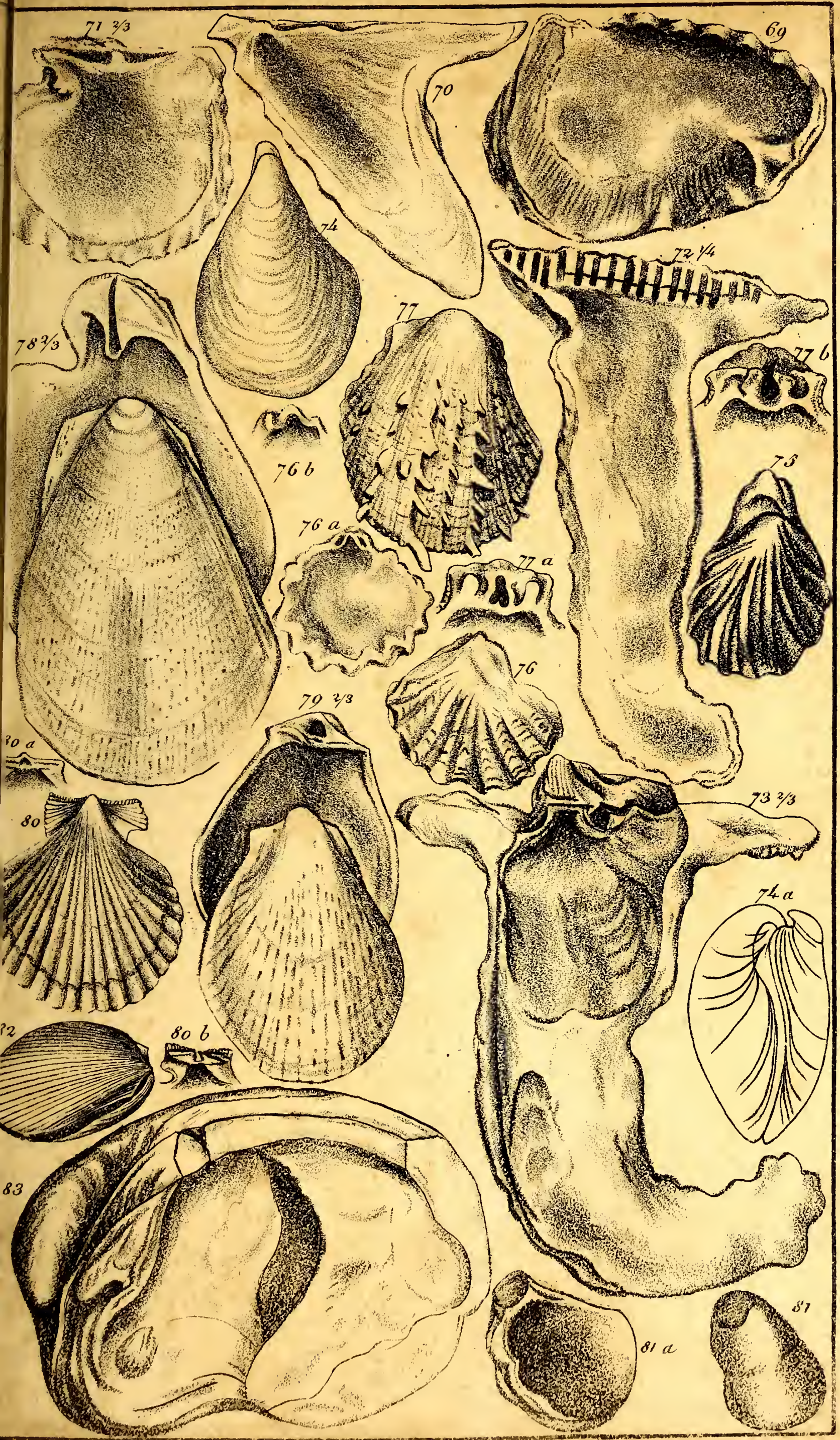





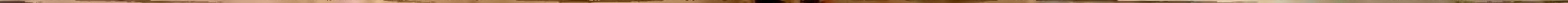






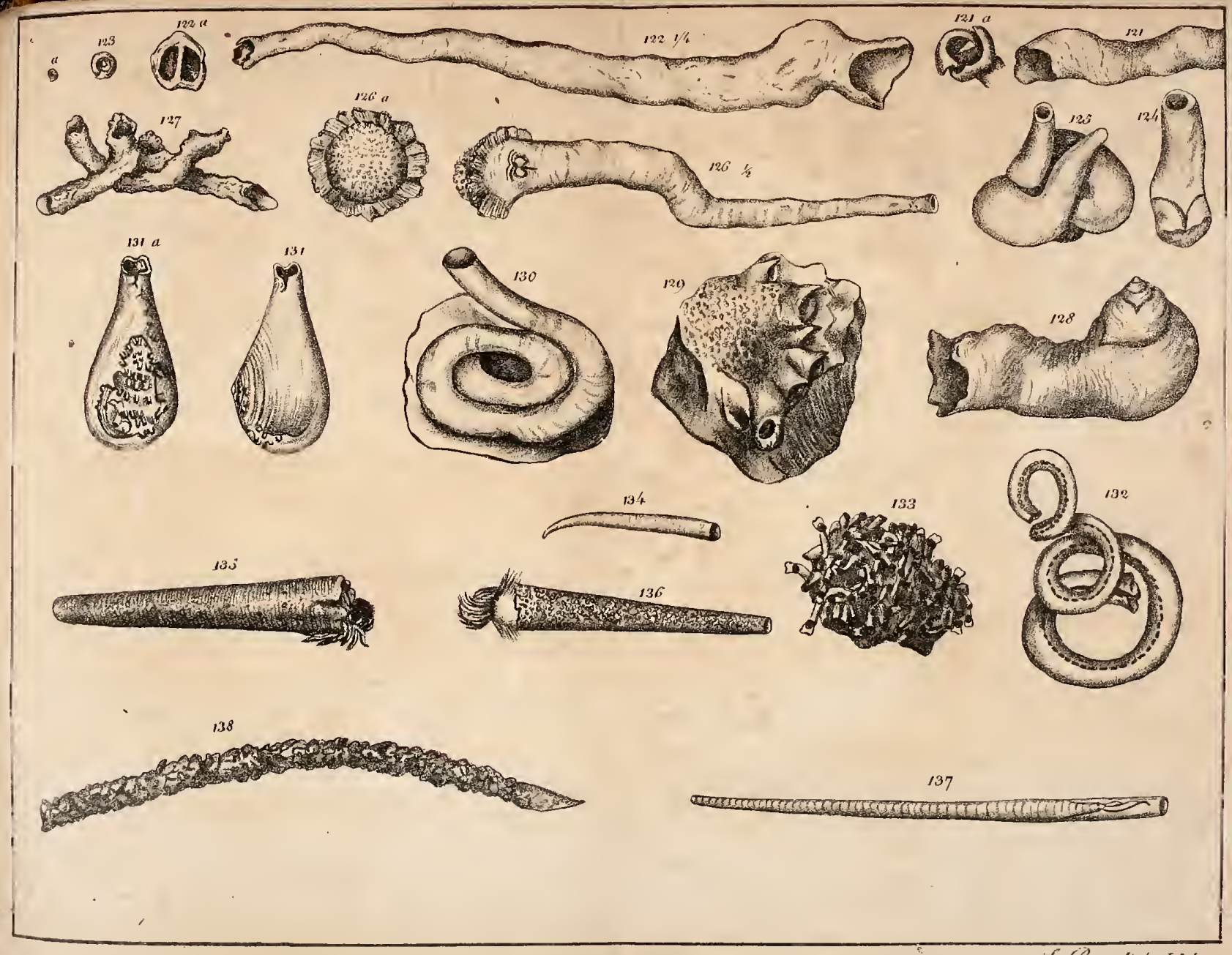






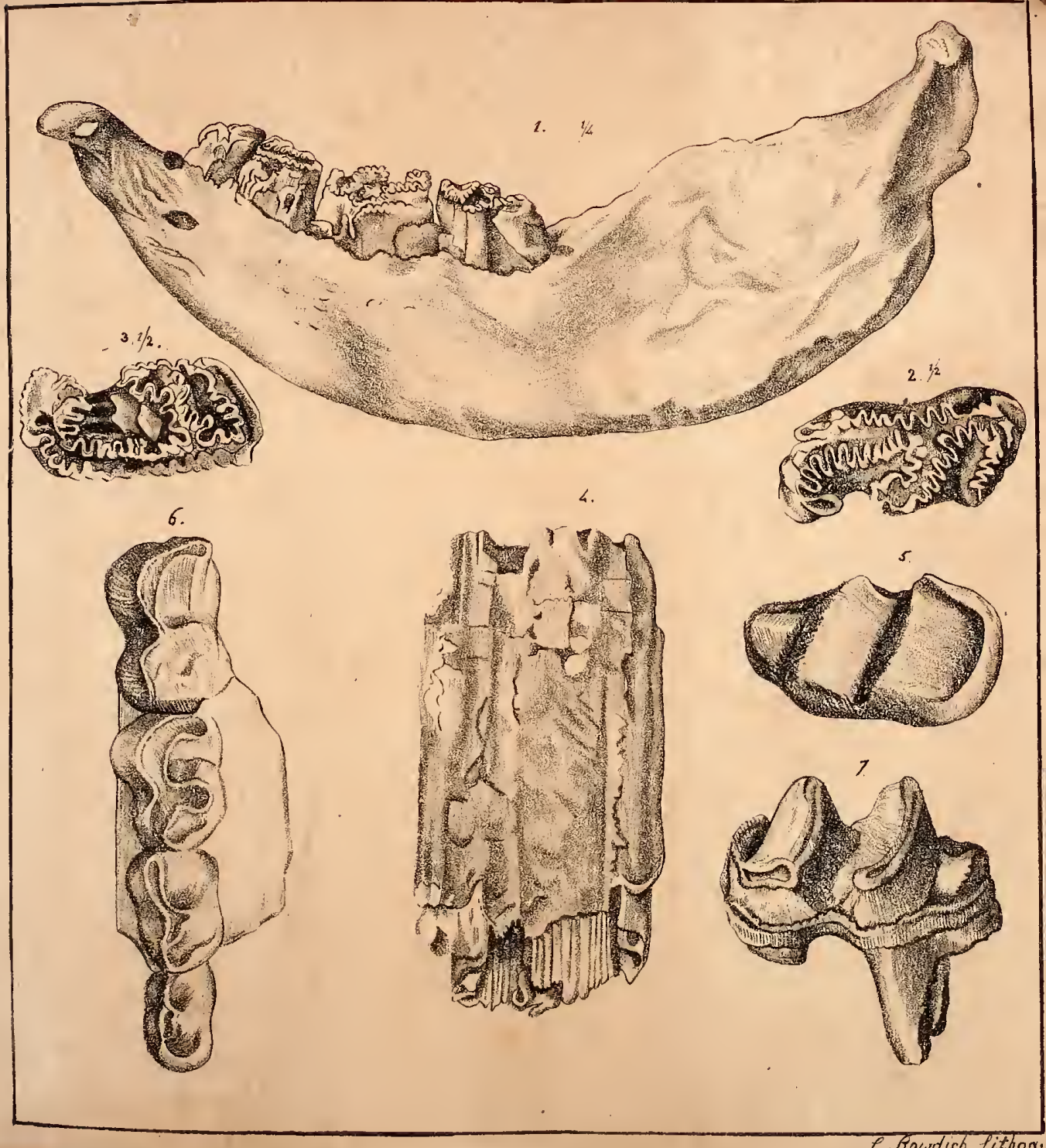





















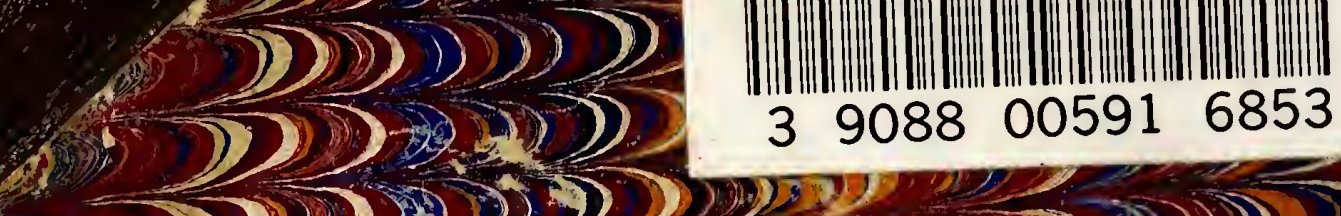

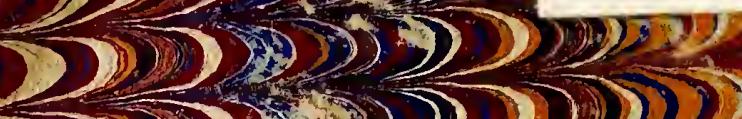

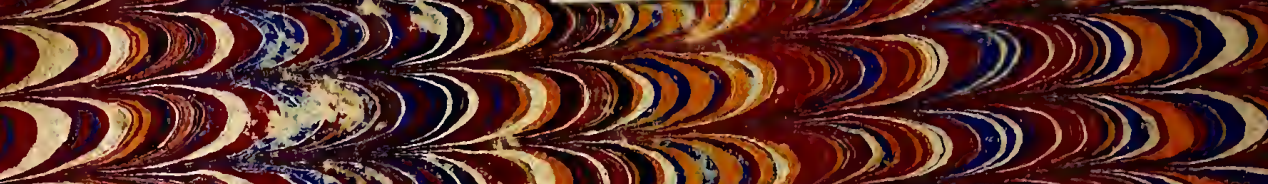

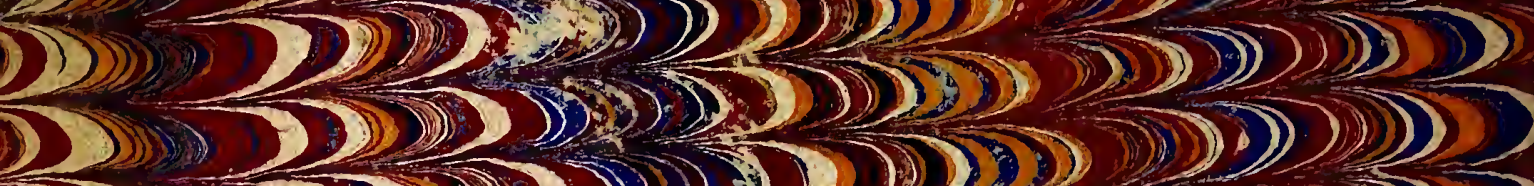

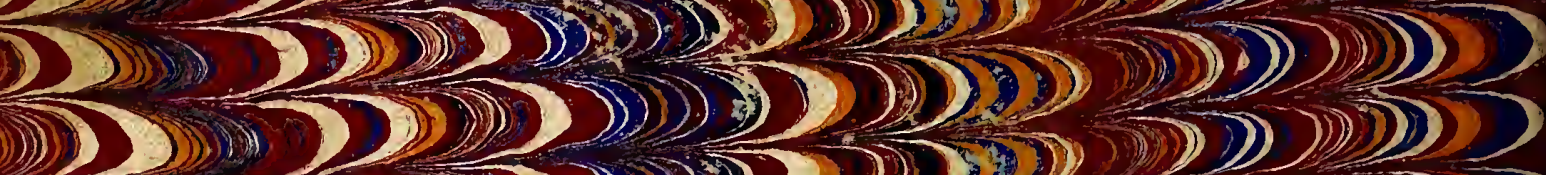

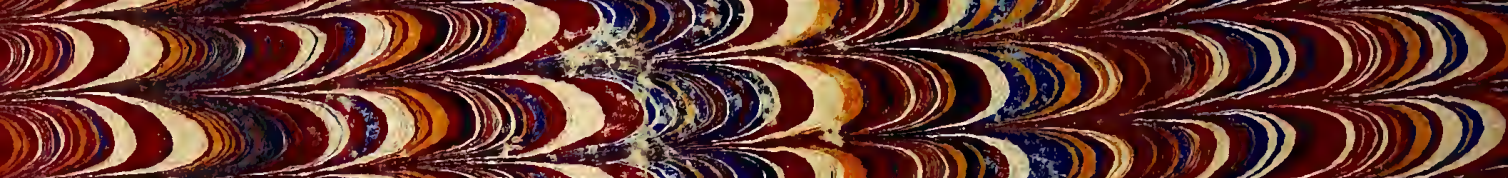

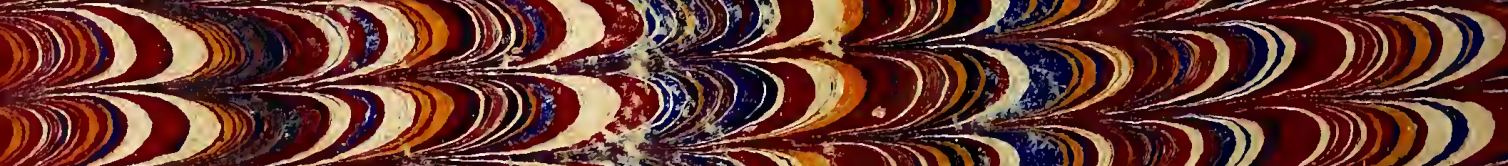

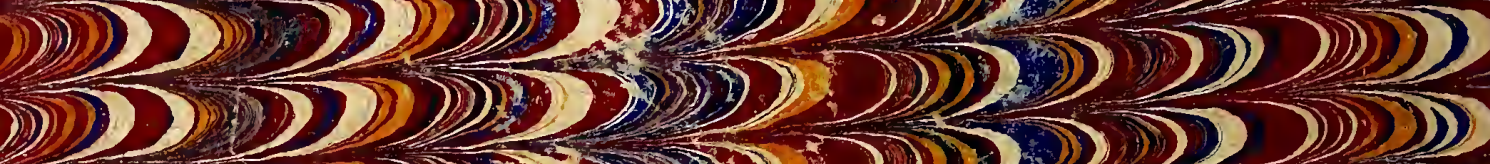

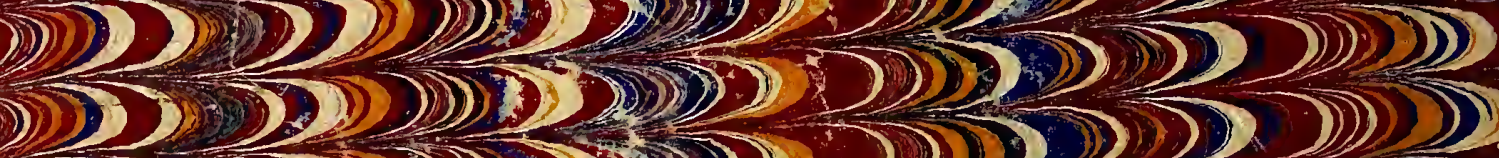

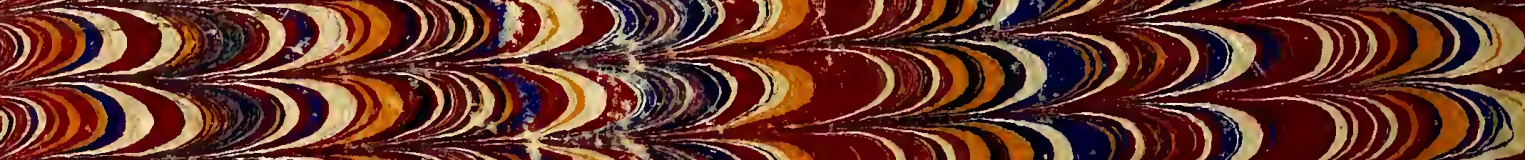

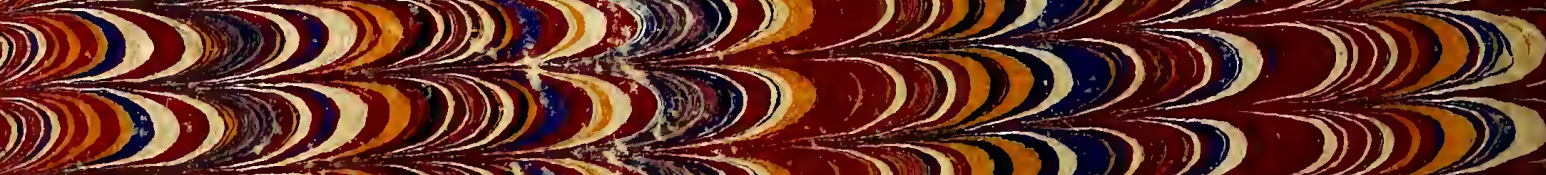

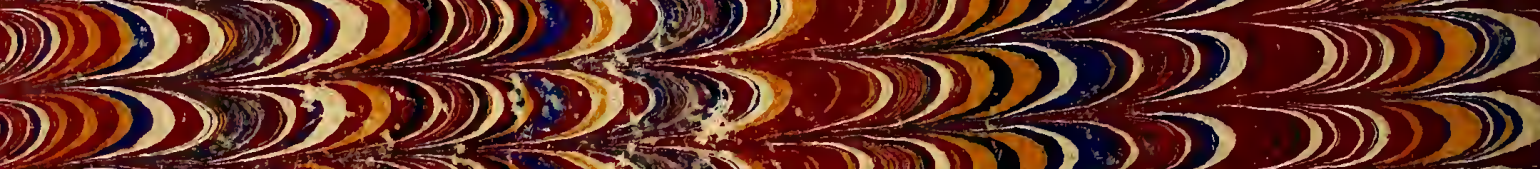

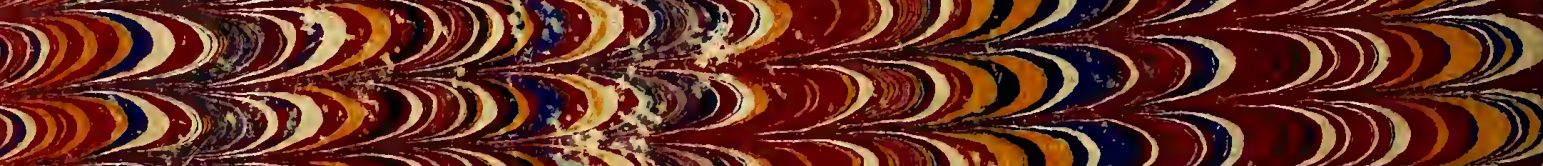

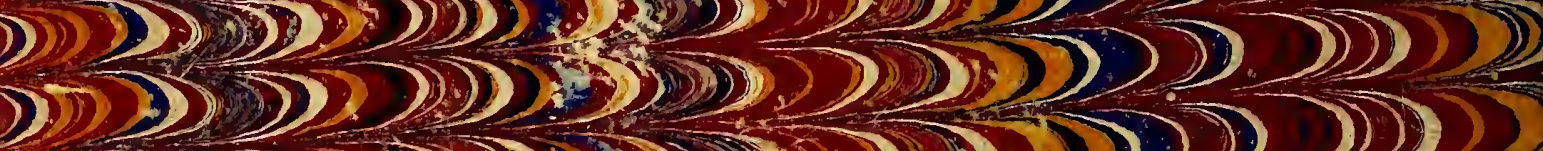

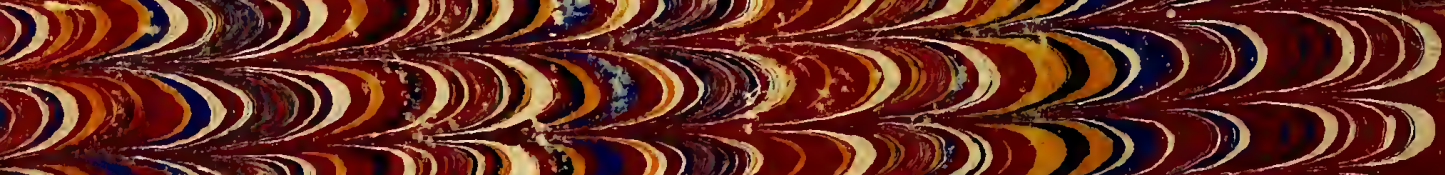

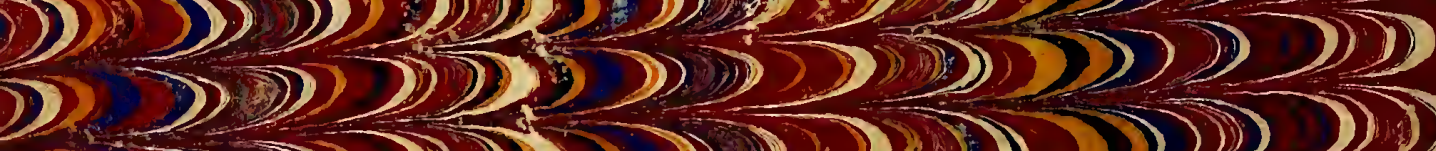

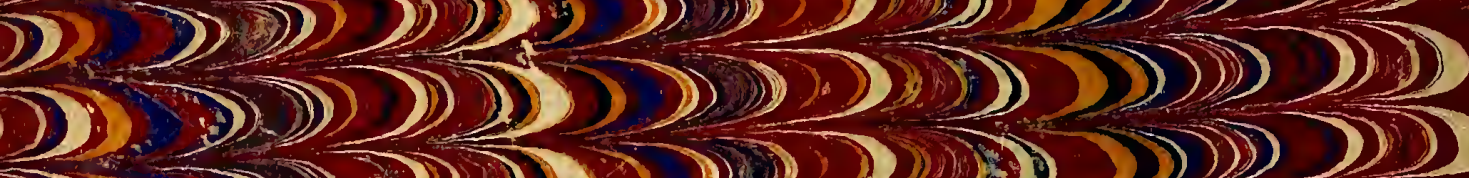

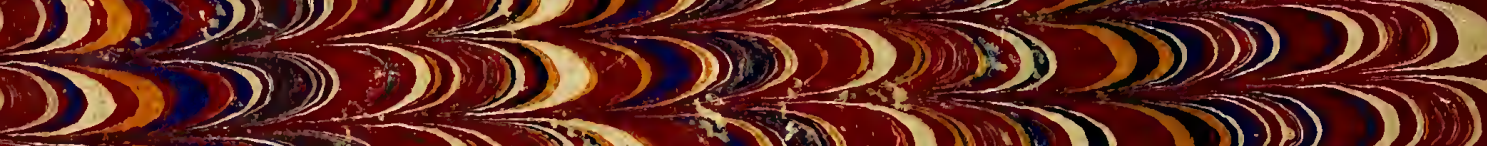

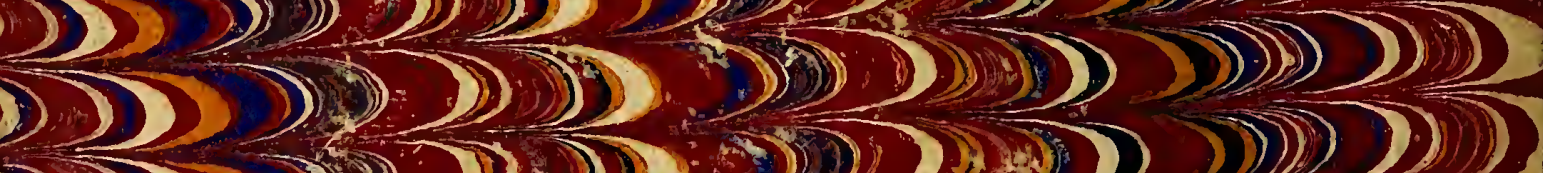

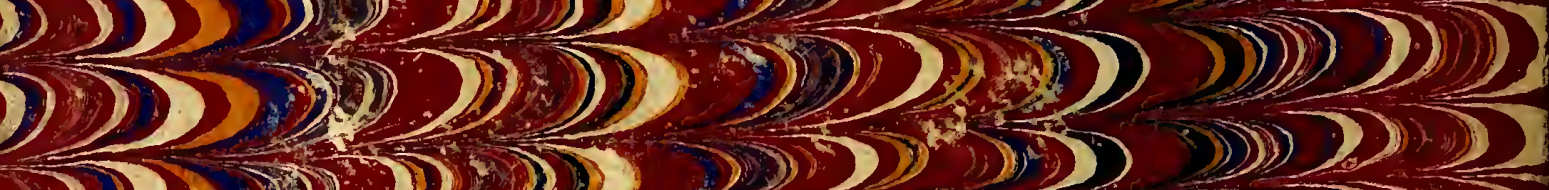

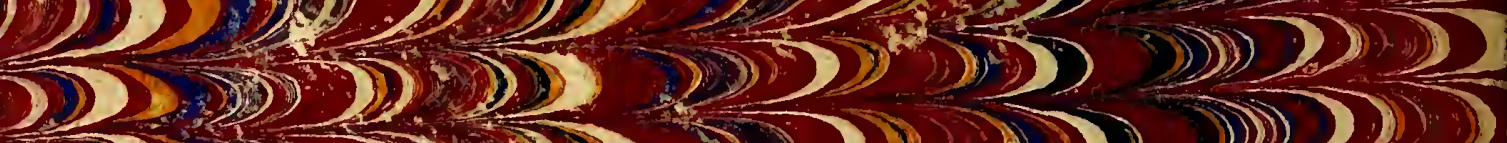

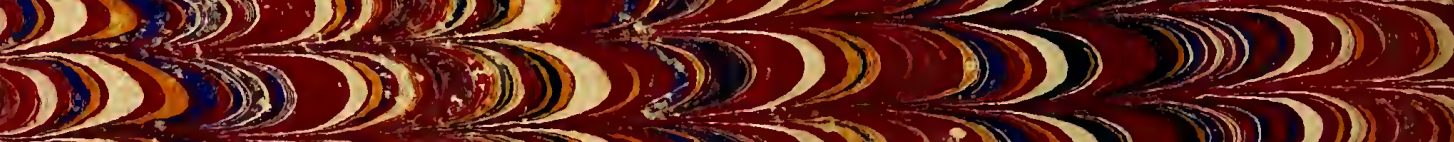

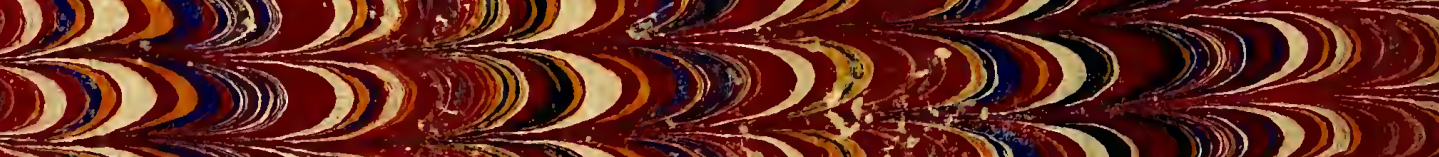

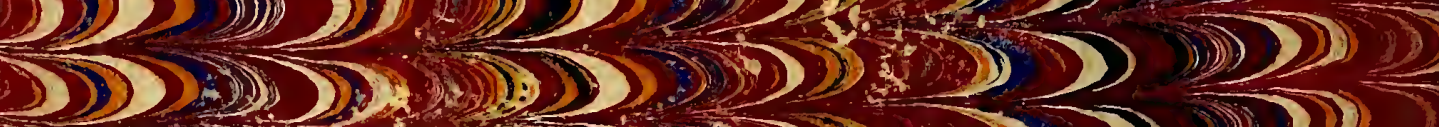

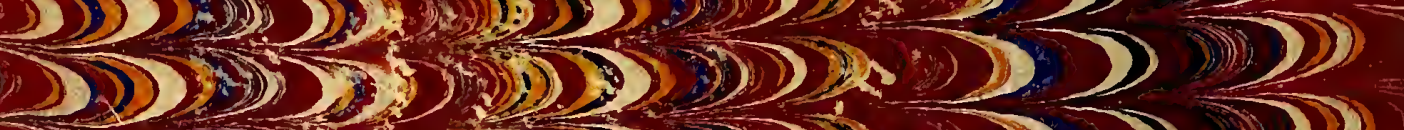

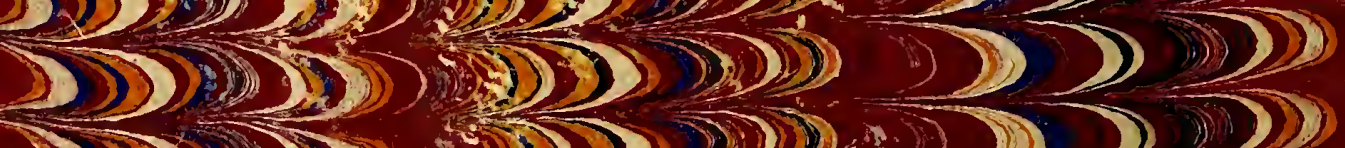

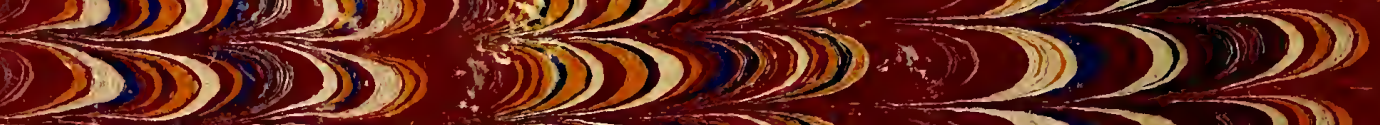

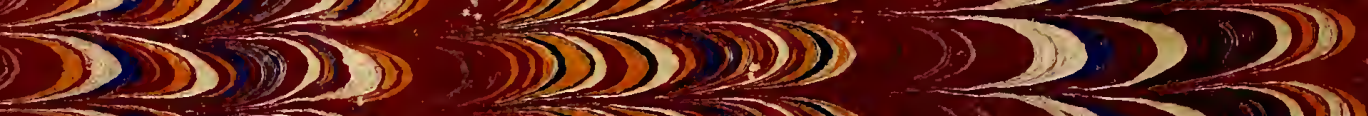

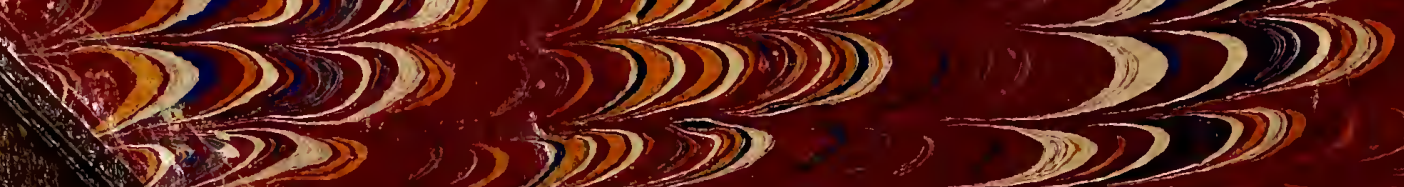

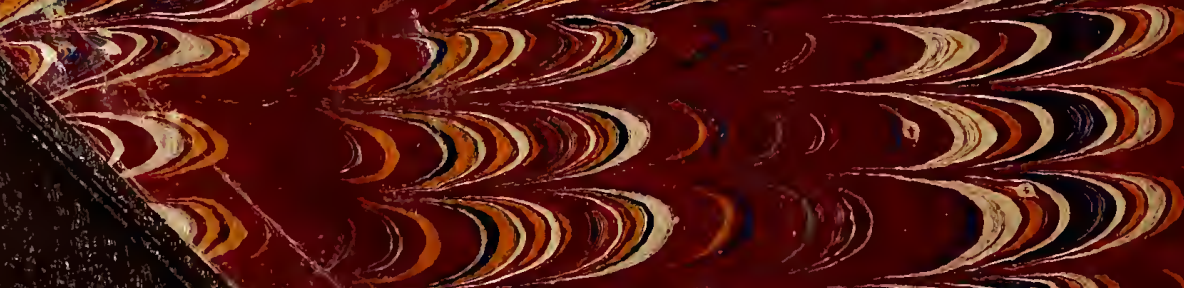

